DOCTORAL THESIS

\title{
In vitro approach of dietary and host related factors affecting digestion of animal-origin foods under Cystic Fibrosis disease
}

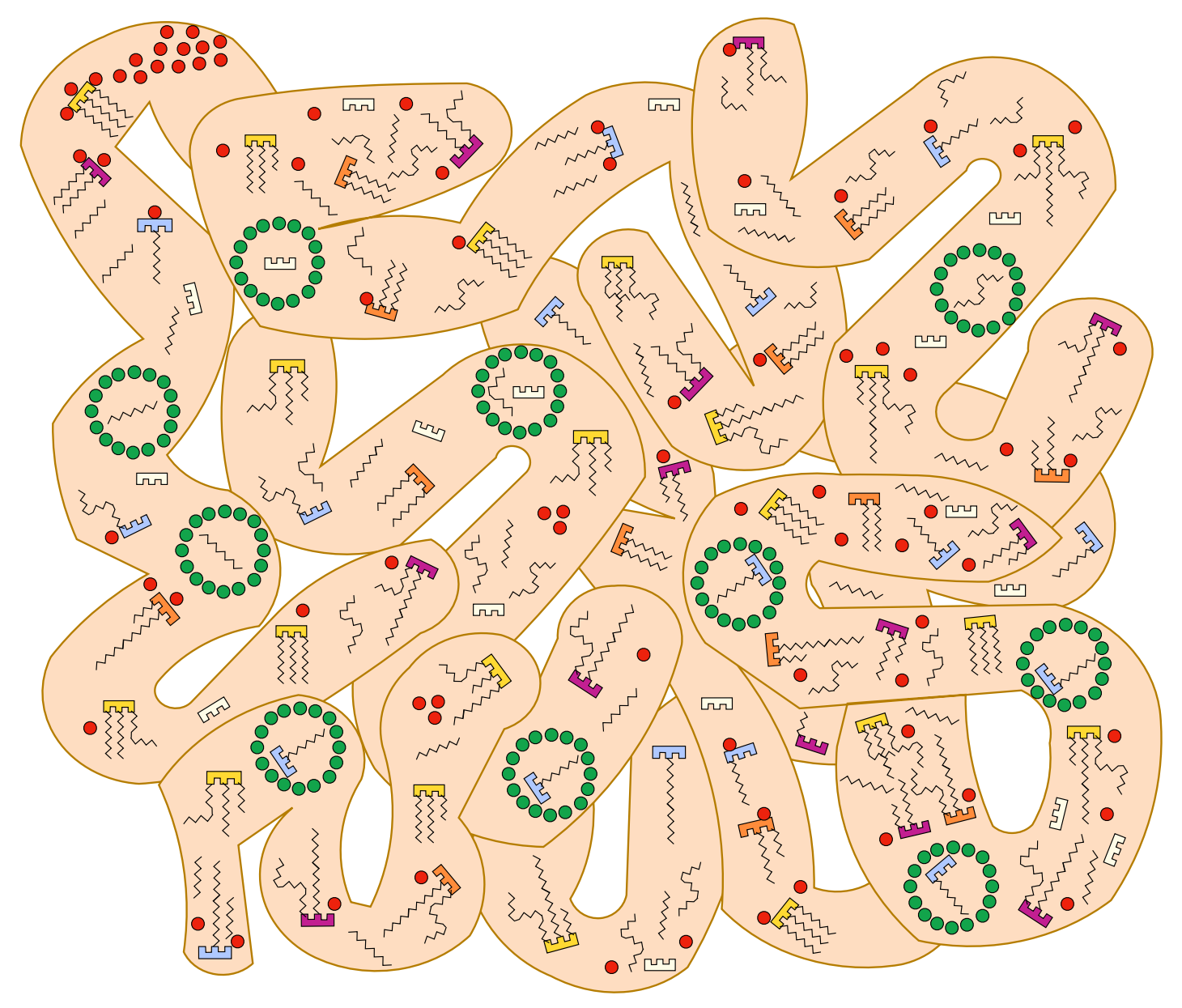

Presented by: Andrea Asensio Grau

Supervised by: Ana Andrés Grau and Ana Heredia Gutiérrez

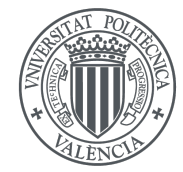

UNIVERSITAT

POLITĖCNICA

DE VALĖNCIA

Universitat Politècnica de València

July 2021 


\section{UNIVERSITAT POLITÈCNICA DE VALÈNCIA}

INSTITUTO UNIVERSITARIO DE INGENIERÍA DE ALIMENTOS PARA EL DESARROLLO
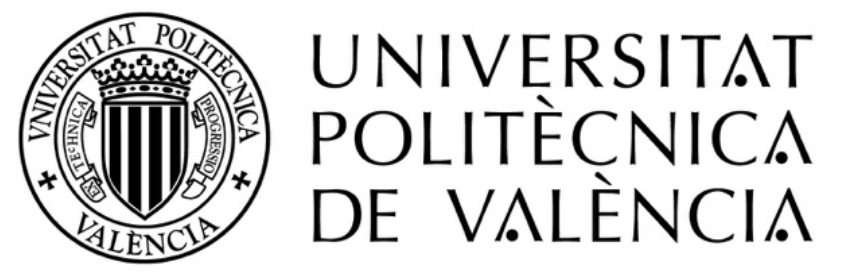

In vitro approach of dietary and host related factors affecting digestion of animal-origin foods under Cystic Fibrosis disease

DOCTORAL THESIS

Presented by:

Andrea Asensio Grau

Supervisors:

Dra. Ana $\mathrm{M}^{\mathrm{a}}$ Andrés Grau Dra. Ana Belén Heredia Gutiérrez

July 2021 


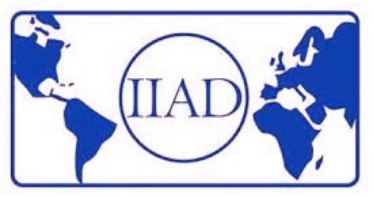

Dra. Ana M ${ }^{a}$ Andrés Grau, Catedrática de Universidad perteneciente al Departamento de Tecnología de Alimentos de la Universidad Politècnica de València,

Dra. Ana Belén Heredia Gutiérrez, profesora titular del Departamento de Tecnología de Alimentos de la Universitat Politècnica de València,

CONSIDERAN: que la memoria titulada "In vitro approach of dietary and host related factors affecting digestion of animal-origin foods under Cystic Fibrosis disease" que presenta Dña Andrea Asensio Grau, para aspirar al grado de Doctor de la Universitat Politècnica de València, y que ha sido realizada bajo su dirección en el Instituto Universitario de Ingeniería de Alimentos para el Desarrollo de la Universitat Politècnica de València, reúne las condiciones adecuadas para constituir su tesis doctoral, por lo que AUTORIZAN a la interesada para su presentación.

Valencia, Abril de 2021

Fdo.: Ana $\mathrm{M}^{\mathrm{a}}$ Andrés Grau

Fdo.: Ana B Heredia Gutiérrez 



\section{Agradecimientos}

En primer lugar, me gustaría agradecerles a mis directoras de tesis, Ana Andrés y Ana Heredia, por el gran apoyo que me han proporcionado durante la ejecución de la tesis. Asimismo, agradecerles la confianza que han depositado en mi durante todo el tiempo que he estado trabajando con ellas. Además de valorares por su inmensa labor en la investigación, también les agradezco la comprensión que me han brindado en todo momento y su fácil accesibilidad. Estoy muy contenta de haber podido realizar este trabajo en su grupo de investigación y de todavía poder seguir trabajando con ellas.

En segundo lugar, agradecerle a mi compañero y marido, Quim, por haberme apoyado, confiado en mi y haber sido más que un amigo y un compañero de trabajo, mi compañero de vida y no dentro de mucho también el padre de nuestro bebé. Te agradezco sobretodo la ilusión que siempre me has transmitido y transmites por la investigación, las ganas de crear, de innovar y de querer mejorar la vida del prójimo. Nunca has dejado de apoyarme ni me has dejado rendirme. Gracias por confiar en mi. Aprovecho para dedicarle la tesis a nuestro pequeño bebé Manel, tenemos mucha ilusión y ganas de conocerte y tenerte en nuestros brazos.

En tercer lugar, agradecer a mi familia todo el apoyo que me han ofrecido durante la larga duración de mis estudios. En especial, a mi madre y a mi hermano, quienes siempre se han mostrado orgullosos de mi. También agradecerles a mis tías, Sonia, Gabriela y Cristina y a mis primos, Pablo, Patricia, Carla, Laura, Esther, Valeria y Alicia, por ese cariño incondicional que me han ofrecido. También me gustaría dar las gracias a mi abuela y mi tía Mariló, que, aunque a día de hoy ya no estén con nosotros sé que parte de lo que he sido, de lo que soy y de lo que seré es gracias a ellas. Han sido dos grandes influencias que por desgracia no han podido acompañarme en este periodo predoctoral.

También me gustaría mencionar a la familia Calvo-Lerma, por su gran acogimiento en la familia y su gran apoyo y aprecio. 
Agradecerles a todos los que han pasado por el laboratorio, los que perduran (Ever, Sara, Aitana, Ruth y Janaina), y los que ya no están (Mariola, Diego, Victoria e Irene), y en especial, a Ari y a Virginia. Arisay, la luz del laboratorio 1.03 que llegó arrasando con todo y que por fin terminó su tesis doctoral en 2019, no sólo una compañera de aventuras si no también una muy buena amiga, una hermana guayaca. A Virginia, por todo el apoyo que ha estado dando a nuestro lab y por todos los buenos consejos que todavía me sigue dando, aunque ya no trabaje con nosotras. Asimismo, me gustaría agradecer a ciertas personas, a Pedro, Marta, Constanza, Miguel y a Jorge, que empezaron siendo mis profesores pero que finalmente han acabado siendo mis amigas y amigos, les agradezco sus consejos, su apoyo y sobre todo su cariño. Agradecer también a todos los compañeros de la tercera planta del IAD, Ángel, Julio, Javi y Chelo, así como a compañeros del departamento con los que he compartido asignaturas, Cristina, Marisa y Lucía, por su gran amabilidad y acogida.

Altough my presencial internship was very short because the pandemic situation I would like to thank my colleagues from Prodigest for their gracious welcome, especially Tim and Jonas, who were very kind to me.

También agradecerles a mis amigos y amigas, no sólo por aguantarme durante estos años si no por tener que aguantarme algunos más. Le agradezco a mis amigos/as ubikianos, Ilde, Cris, Ramón, Carlos, Vane, Ricardo, Lola y Aleix por esos días tan agradables y divertidos que solemos pasar juntos. A mi mezcla de amigos de diversos orígenes como son Kosko, Eva, Ximo, Bruno y Luís, por todos los buenos momentos, las risas y los apoyos que me habéis ofrecido. A mis amigos/as del colegio (Lucía, Nadia, Bea, Jessica, etc.) e instituto (Lucía, Karla, Silvia, Camila, Guillermo, etc.), porque por mucho que pase el tiempo la amistad siempre perdura. A mis compas y amigos de la carrera, en especial a Jose y a Claudia, porque todo empezó en el poli y continúa fuera, pero entre nosotros las cosas no cambian. A todas las nuevas adquisiciones que he conocido este año como son Sari, Paula, Ximo y Rober, verdaderamente toda una sorpresa que nuestros 
caminos se hayan cruzado repentinamente, verdaderamente siempre se agradece conocer a gente como vosotros/as.

Finalmente, me gustaría agradecerme a mi misma el gran esfuerzo que he realizado no sólo en la tesis doctoral si no a lo largo de la vida. He aprendido que todo lo que se quiere cuesta de ganarlo, pero con empeño y constancia no hay nada que pueda resistírsenos. Este periodo predoctoral ha sido otra etapa más a completar que siempre recordaré con ilusión. Desde el comienzo de mi vida universitaria supe que quería hacer un doctorado, y el empeño y las ganas por aprender y mejorar son las que me han llevado a donde me encuentro hoy. Me doy las gracias a mi misma por no haberme rendido nunca, por ser optimista y querer vivir la vida con intensidad y positividad, me doy las gracias por haber dejado entrar en mi vida a gente tan maravillosa que me facilita la existencia y me aporta felicidad. Agradezco vivir el presente y disfrutarlo sin perderme en qué ocurrirá en el futuro.

Námaste 



\section{ABSTRACT}

Among the available methodologies to study food digestion, in vitro digestion models have raised as a valid procedure. In vitro digestion consists of simulating the digestion process in the laboratory, by reproducing the physiological conditions in terms of digestive fluids composition (electrolytes and enzymes), $\mathrm{pH}$, temperature, mechanical forces and duration of the oral, gastric and intestinal stages.

Addressing the study of nutrient digestion is of special relevance in pathologies coursing with pancreatic or hepatic alterations, which are associated with compromised intestinal lipid digestion due to reduced secretion of pancreatin, bicarbonate and bile salts. This is the case of Cystic Fibrosis along with pancreatic insufficiency, and the patients suffering this condition have to follow pancreatic enzyme replacement therapy, the exogenous supply of encapsulated pancreatin. However, the dose of this supplement should be adjusted to the specific characteristics of foods, and no valid method was available for such purpose. To tackle this challenge, the EU-funded project MyCyFAPP succeed to develop a method to adjust the optimal dose the enzyme supplements used in the therapy. The present doctoral thesis was conducted as a relevant part of this project.

Concretely, this thesis aims at addressing the study of lipid digestion in foods to generate new knowledge regarding nutrient digestion in animal origin dietary sources (egg, meat and meat products, cheese and fish) in the context of Cystic Fibrosis. To address this goal a static in vitro digestion model was applied. The role of inherent-to-food characteristics (resulting food matrix structure from processing) and host related factors ( $\mathrm{pH}$ and bile salts concentration and pancreatin concentration) were explored as determinants of lipolysis in animal-origin foods.

Along the four chapters presented, focused on egg, meat, cheese and fish, a common experimental design was applied to study lipolysis, proteolysis and matrix degradation. In each study, different processing techniques applied to the assessed foods allowed for evaluating the effect of inherent-to-food properties on the study outcomes as well. The results have contributed to the development of a new evidence-based method to optimise pancreatic enzyme replacement therapy, and inform the scientific community about new insights on the behaviour of different foods undertaking the digestion process. 


\section{RESUMEN}

De entre las metodologías disponibles para estudiar la digestión de alimentos, los modelos de digestión in vitro se plantean como procedimientos válidos para este propósito. La digestión in vitro consiste en simular el proceso de digestión en el laboratorio, reproduciendo las condiciones fisiológicas en cuanto a composición de los fluidos digestivos (electrolitos y enzimas), $\mathrm{pH}$, temperatura, fuerzas mecánicas y duración de las etapas oral, gástrica e intestinal.

Abordar el estudio de la digestión de nutrientes es de especial relevancia en patologías que cursan con alteraciones pancreáticas o hepáticas, asociadas a una digestión de lípidos comprometida en la etapa intestinal, debido a la disminución de secreción de pancreatina, bicarbonato y sales biliares. Este es el caso de la fibrosis quística con insuficiencia pancreática, y los pacientes que padecen esta afección deben seguir la terapia de sustitución de enzimas pancreáticas, que consiste en el suministro exógeno de pancreatina encapsulada. Sin embargo, la dosis de este suplemento debe ajustarse a las características de los alimentos y no se dispone de ningún método válido para tal fin. Para hacer frente a este reto, en el proyecto financiado con fondos europeos MyCyFAPP se ha logrado desarrollar un método para ajustar la dosis óptima de los suplementos enzimáticos utilizados en la terapia. La presente tesis doctoral se realizó en el marco de dicho proyecto.

Concretamente, esta tesis tiene como objetivo abordar el estudio de la digestión de lípidos en los alimentos de origen animal (carne y productos cárnicos, huevos, queso y pescado) en el contexto de la fibrosis quística. Para abordar este objetivo se aplicó un modelo de digestión in vitro estático con el fin de explorar el papel de las características inherentes a los alimentos (estructura de la matriz alimentaria como resultado del procesado) y los factores relacionados con el individuo $(\mathrm{pH}$, concentración de sales biliares y concentración de pancreatina) como factores determinantes de la lipólisis en alimentos de origen animal.

A lo largo de los cuatro capítulos presentados, centrados en el huevo, la carne, el queso y el pescado, se presenta un diseño experimental común para estudiar la lipólisis, la proteólisis y la degradación de la matriz. En cada estudio, las diferentes técnicas de 
procesado aplicadas a los alimentos evaluados también permitieron evaluar el efecto de las propiedades inherentes a los alimentos en los resultados del estudio. Los resultados han contribuido al desarrollo de un nuevo método basado en la evidencia para optimizar la terapia de reemplazo de enzimas pancreáticas e informan a la comunidad científica sobre nuevos conocimientos en el comportamiento de diferentes alimentos sometidos al proceso de digestión. 


\section{RESUM}

De les metodologies disponibles per estudiar la digestió d'aliments, els models de digestió in vitro es plantegen com a procediments vàlids per a aquest propòsit. La digestió in vitro consisteix en simular el procés de digestió al laboratori, reproduint les condicions fisiològiques pel que fa a la composició dels fluids digestius (electròlits i enzims), $\mathrm{pH}$, temperatura, forces mecàniques i durada de les etapes oral, gàstrica $\mathrm{i}$ intestinal. Abordar l'estudi de la digestió de nutrients és d'especial rellevància en patologies que cursen amb alteracions pancreàtiques o hepàtiques, associades a una digestió de lípids compromesa en l'etapa intestinal, a causa de la disminució de secreció de pancreatina, bicarbonat i sals biliars. Aquest és el cas de la fibrosi quística amb insuficiència pancreàtica. Els pacients que pateixen aquesta afecció han de seguir la teràpia de substitució d'enzims pancreàtics, que consisteix en el subministrament exogen de pancreatina encapsulada. No obstant això, la dosi d'aquest suplement ha d'ajustar-se a les característiques dels aliments i actualment no es disposa de cap mètode vàlid per a tal fi. Per enfrontar a aquest repte, en el projecte finançat amb fons europeus, MyCyFAPP, s'ha aconseguit desenvolupar un mètode per a ajustar la dosi òptima dels suplements enzimàtics utilitzats en la teràpia. La present tesi doctoral es va realitzar en el marc d'aquest projecte.

Concretament, aquesta tesi té com a objectiu abordar l'estudi de la digestió de lípids en els aliments d'origen animal (ous, carn i productes carnis, formatge i peix) en el context de la fibrosi quística. Per a abordar aquest objectiu es va aplicar un model de digestió in vitro estàtic amb la finalitat d'explorar el paper de les característiques inherents als aliments (estructura de la matriu alimentària com a resultat del processament) i els factors relacionats amb l'individu $(\mathrm{pH}$, concentració de sals biliars i concentració de pancreatina) com a factors determinants de la lipòlisi en aliments d'origen animal.

Als quatre capítols presentats, centrats en l'ou, carn, formatge i peix, es presenta un disseny experimental comú per a estudiar la lipòlisi, la proteòlisi i la degradació de la matriu. En cada estudi, les diferents tècniques de processament aplicades als aliments avaluats també van permetre avaluar l'efecte de les propietats inherents als aliments en els resultats de l'estudi. Els resultats han contribuït al desenvolupament d'un nou mètode 
basat en l'evidència per a optimitzar la teràpia de substitució d'enzims pancreàtics i informen la comunitat científica sobre nous coneixements en el comportament de diferents aliments sotmesos al procés de digestió. 


\section{TABLE OF CONTENTS}

CONTEXT

MyCyFApp project.

Cystic Fibrosis (CF) and Pancreatic Enzyme Replacement Therapy

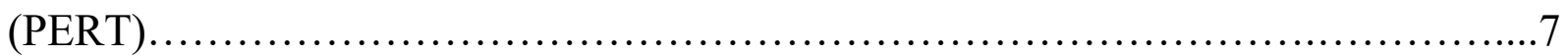

Dosage criteria in PERT: MyCyFApp approach......................................

1.INTRODUCTION

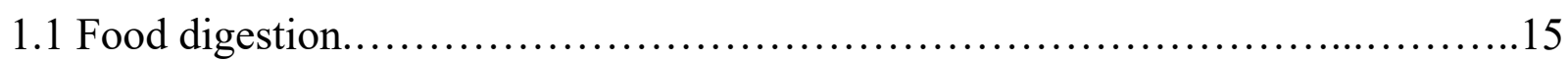

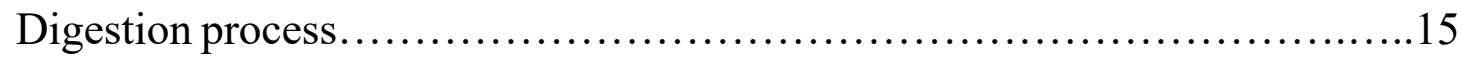

Digestion and absorption of nutrients...................................23

Factors affecting bioaccessibility and bioavailability of nutrients.............27

1.2 Gastrointestinal alterations in CF and their impact on digestibility and bioaccessibility of nutrients: MyCyFApp approach.................................................

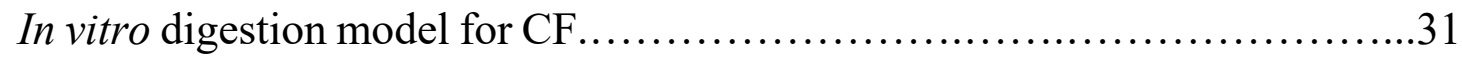

Dietary habits in patients with CF defining the focus food

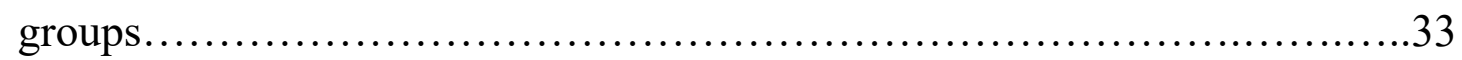

Lipid digestibility of vegetal-origin food products..........................37

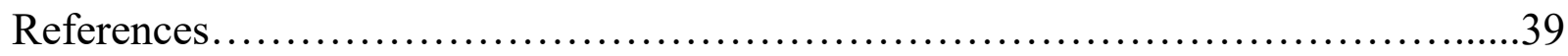

2. OBJECTIVES AND WORKING PLAN 48

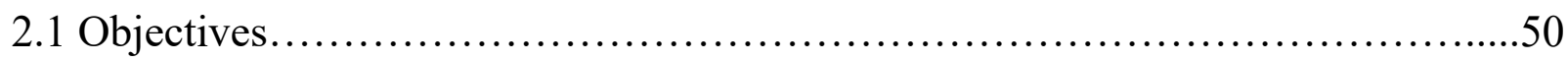

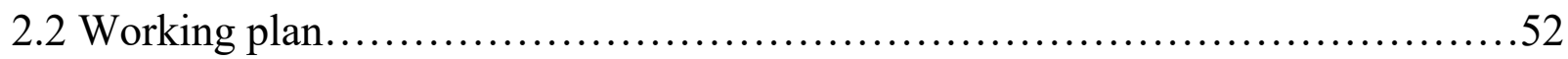

3. MATERIALS AND METHODS

3.1. Sample preparation and characterisation..................................56

3.2. Simulation of in vitro gastrointestinal digestion in CF.........................60

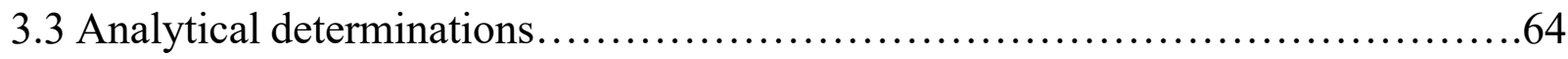

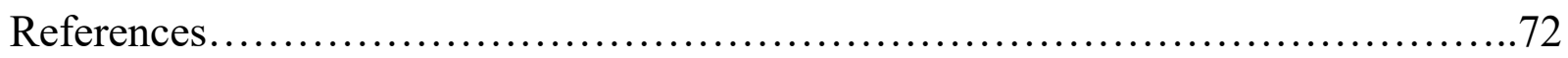

4. RESULTS $\mathbf{7 4}$

Chapter 1. Effect of cooking methods and intestinal conditions on lipolysis, proteolysis and xanthophylls bioaccessibility of eggs. ................................... 76

Chapter 2. Fat digestibility in meat products: influence of food structure and gastrointestinal conditions. ................................................ 110 Chapter 3. In vitro study of cheese digestion: effect of type of cheese and intestinal conditions on macronutrients digestibility. .................................. 137 
Chapter 4. In vitro digestion of salmon: influence of processing and intestinal conditions on macronutrients digestibility................................................ 166

5. CONCLUDING REMARKS 198

6. FUTURE PERSPECTIVES 204 


\section{LIST OF FIGURES}

Figure 1. Summary of the project: generated tools (A), expected final scenario at the end of the project (B) and desired outcomes (C). Open-access figure extracted from Calvo-Lerma et al., 2017a.

Figure 2. General overview and inter-relation of the different work-packages (WP) of the project. Open-access figure extracted from Calvo-Lerma et al., 2017a. 3

Figure 3. Difference in lipid digestion in the context of a functional pancreas and exocrine pancreatic insufficiency.... 8

Figure 4. Schematic overview of the components supporting the prediction of the optimal dose of enzyme supplements. The core item is the Theoretical optimal dose database, in which all foods regularly consumed are assigned with a TOD value in LU/g fat.

Figure 5. Change in coefficient of fat absorption (right) and enzyme supplements dose (left) at the end of the MyCyFAPP clinical trial study period compared to the study baseline, after using the evidence-based method to adjust the dose of enzyme supplements during 6 months (Calvo-Lerma et al., 2020b).

Figure 1.1. Overview of the main processes and enzymatic reactions occurring at the oral stage.

Figure 1.2. Overview of the main processes and enzymatic reactions occurring at the gastric stage.

Figure 1.3. Overview of the main processes and enzymatic reactions occurring at the small intestinal stage. 
Figure 1.4. Overview of the main processes and enzymatic reactions occurring at the large intestinal stage.

Figure 2.1. Overview of the thesis objectives

Figure 3.1. Overview of the experimental plan. Four animal origin food groups were processed prior in vitro digestion (A); two sets of gastrointestinal simulated conditions were established according to standard healthy and exocrine pancreatic insufficiency (EPI) and cystic fibrosis (CF) situations (B); an in vitro digestion model was set up and the specifications for the oral, gastric and intestinal stage were established $(\mathrm{C})$; a range of lipase concentrations was studied in all the experimental plans; and after the simulation of the intestinal stage, proteolysis, micronutrient bioaccessibility, lipolysis and matrix degradation were determined (D) ...................................... 71

Figure 4.1. Graphical abstract of in vitro evaluation of lipid digestibility in egg products under standard and cystic fibrosis intestinal conditions.

Figure 4.2. Matrix degradation index (\%) (A), TCA Soluble Protein (\%) (B) and Lipolysis extent (\%) (C) obtained for the different egg matrices after in vitro digestion at fixed duodenal conditions of $\mathrm{pH} 6$ and Bile concentration $1 \mathrm{mM}$ using different doses of Kreon (0-4000 LU/g fat $\approx 0-57-107-160-213$ Protease Units / g of protein). Letters (a-e) refer to the homogenous groups obtained for different doses $(0-4000)$ for the same egg matrix (boiled, poached and omelette) at a statistical significance of $95 \%$ (p-value $<0.05)$ .94

Figure 4.3. Graphical abstract of in vitro evaluation of lipid digestibility in meat product under standard and cystic fibrosis intestinal conditions 113 
Figure 4.4. Matrix degradation index (MDI, \%) of the meat products after in vitro digestion with five pancreatic enzyme supplements concentrations (enzyme dose, LU/g fat), classified according to the food matrix structure

Figure 4.5. Lipolysis extent (total FFA, $\mathrm{mg} / \mathrm{g}$ fat) of the meat products after in vitro digestion with five pancreatic enzyme supplements concentrations (enzyme dose, LU/g fat), classified according to the food matrix structure.

Figure 4.6. Linear mixed regression model plot. (A) Effect of the food matrix (natural or processed) on matrix degradation index (MDI): processed matrices have significantly higher MDI ( $p=0.013,95 \%$ CI $[8.148,30.612])$. (B) Effect of the MDI on the total FFA released: the higher the MDI, the higher the total FFA released ( $<<0.001,95 \%$ CI [6.128, $9.606])$

Figure 4.7. Linear mixed regression model plot. (A) Effect of the intestinal $\mathrm{pH}$ (6 or 7) on total FFA: $\mathrm{pH} 7$ allows for significantly higher amount of FFA released $(\mathrm{p}<0.001$, 95\% CI [53.466, 168.923]). (B) Effect of the bile salts concentration on the total FFA released: $10 \mathrm{mM}$ concentration allows for significantly higher amount of FFA released $(\mathrm{p}<0.001,95 \%$ CI $[90.188,205.645])$.

Figure 4.8. Graphical abstract of in vitro evaluation of lipid and protein digestibility in cheeses under standard and cystic fibrosis intestinal conditions 140

Figure 4.9. FFA profile of different cheese matrices after in vitro digestion simulating two intestinal scenarios corresponding to a healthy adult ( $\mathrm{pH} 7$ and bile $10 \mathrm{mmol} / \mathrm{L}$ ) and the most disadvantageous EPI conditions $(\mathrm{pH} \quad 6$ and bile $1 \mathrm{mmol} / \mathrm{L}$ ). 154

Figure 4.10. Matrix degradation index (\%) (A) and Lipolysis extent (\%) (B) obtained for the different cheese matrices after in vitro digestion at fixed duodenal conditions of 
pH 6 and Bile concentration $1 \mathrm{mmol} / \mathrm{L}$ using different doses of Kreon $(0-4000 \mathrm{LU} / \mathrm{g}$ fat)

Figure 4.11. Graphical abstract of in vitro evaluation of lipid and protein digestibility in salmon under standard, exocrine pancreatic insufficiency and cystic fibrosis intestinal conditions 169

Figure 4.12. Distribution of lipid species present in raw, marinated and cooked salmon, assessed by nuclear magnetic resonance. The small graphic shows a zoom of the 2-MG, $1-\mathrm{MG}$ and FA. *Different letters mean statistically significant $(\mathrm{p}<0.05)$ differences between salmon preparations

Figure 4.13. Matrix degradation index (\%), proteolysis (\%) and lipolysis extent (\%) achieved in raw, marinated and cooked salmon under standard intestinal conditions $\mathrm{pH}$ 7, bile salts concentration $10 \mathrm{mM}$ ) and pancreatin concentration $2000 \mathrm{LU} / \mathrm{g}$ lipid (A). Distribution of lipid species (molar percentage) in terms of triglycerides (TG), 1,3diglycerides (1,3-DG), 1,2-diglycerides (1,2-DG), 2-monoglycerides (2-MG), 1monoglycerides (1-MG) and fatty acids (FA) under standard intestinal conditions and pancreatin concentration $2000 \mathrm{LU} / \mathrm{g}$ lipid (B). The small graphic shows a zoom of the 1,3-DG, 1,2-DG, 2-MG and 1-MG. *Different letters mean statistically significant $(p<0.05)$ differentces between salmon preparations. Results correspond to $120 \mathrm{~min}$ of intestinal digestion

Figure 4.14. Matrix degradation index (\%), proteolysis (\%) and lipolysis extent (\%) in the salmon samples after in vitro digestion under both altered intestinal scenarios and pancreatin concentration of $2000 \mathrm{LU} / \mathrm{g}$ lipid: reduced $\mathrm{pH}$ and bile salts concentration ( $\mathrm{pH} 6$, bile salts concentration $1 \mathrm{mM}$ ) (A) and reduced $\mathrm{pH}$ and normal bile salts concentration ( $\mathrm{pH} 6$, bile salts concentration $10 \mathrm{mM}$ ) (B). Distribution of lipid species (molar percentage) under both intestinal scenarios and pancreatin concentration 2000 LU/g lipid: reduced $\mathrm{pH}$ and bile salts concentration (C) and reduced $\mathrm{pH}$ and normal bile salts concentration (D). The small graphic shows a zoom of the 1,3-DG, 1,2-DG, 2-MG 
and 1-MG. *Different letters mean statistically significant $(\mathrm{p}<0.05)$ differences between salmon preparations. Results correspond to $120 \mathrm{~min}$ of intestinal

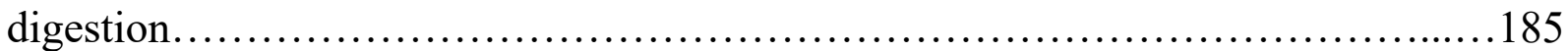

Figure 4.15. Matrix degradation index (\%), proteolysis (\%) and lipolysis extent (\%) achieved in raw, marinated and cooked salmon at different pancreatin concentration $(0$, 2000, 4000 and $6000 \mathrm{LU} / \mathrm{g}$ lipid. The corresponding protease activities were 0, 44, 88 and $132 \mathrm{PU} / \mathrm{g}$ protein in raw salmon, $0,70,140$ and $210 \mathrm{PU} / \mathrm{g}$ protein in marinated salmon and 0, 43, 87 and $130 \mathrm{PU} / \mathrm{g}$ protein in cooked salmon. *Different letters mean statistically significant $(\mathrm{p}<0.05)$ differences between the pancreatin concentration. Results correspond to 120 min of intestinal digestion..............................190 


\section{LIST OF TABLES}

Table 1. The consortium of MyCyFAPP Project..................................

Table 1.1. Food groups classification according to MyCyFAPP Project, including those considered as representative of each, which were selected for studying fat digestion with the in vitro digestion model. Highlighted in bold the foods that were specifically studied in the framework of this doctoral thesis............................................34

Table 3.1. Characteristics (ingredients among others) of industrial-processed products as well as the processing conditions applied to some food matrices

Table 3.2. Experimental design addressed in the different chapters.

Table 3.3. Simulation parameters describing the CF-pancreatic insufficiency in vitro digestion model.

Table 3.4. Composition of simulated digestion fluids. 64

Table 4.1: Composition of simulated digestion fluids .86

Table 4.2. Matrix degradation index (\%), TCA Soluble Protein (\%) and Lipolysis extent (\%), obtained for the different egg matrices after the in vitro digestion process using a fixed enzyme dose $(2000 \mathrm{LU} / \mathrm{g}$ fat $)$ and different duodenal conditions of $\mathrm{pH}$ and Bile concentration

Table 4.3. F-ratio obtained from factorial ANOVA analysis for MDI (\%). TCA soluble protein, Lipolysis extent (\%) and Zeaxanthin and Lutein bioaccessibility (\%). The factors for the analysis were $\mathrm{pH}$, bile concentration and cooking method. The multifactor ANOVA was applied only to the data obtained at a fixed dose of $2000 \mathrm{LU} / \mathrm{g}$ fat. 
Table 4.4. Lutein and Zeaxanthin content in raw egg, boiled, poached and omelette before digestion. Contents are expressed in $\mu \mathrm{g} / \mathrm{g}$ product and $\mu \mathrm{g} / \mathrm{g}$ dry matter. 98

Table 4.5. Lutein and Zeaxanthin bioaccessibility (\%) as a function of different doses of Kreon (0-4000 LU/g fat) and intestinal conditions of $\mathrm{pH}(6$ and 7) and bile concentration (1 and $10 \mathrm{mM})$ 100

Table 4.6. Composition of simulated digestion fluids. 118

Table 4.7. Characterization of water, fat and protein content in the different meat matrices expressed as $\mathrm{g} / \mathrm{g}$ of product.

Table 4.8. Matrix Degradation Index (\%) obtained for the different meat matrices (hamburger, sausage, luncheon ham, pate, cured ham, cooked ham, chicken drum, pork loin and beef steak) after the in vitro digestion process using a fixed enzyme dose (2000 $\mathrm{LU} / \mathrm{g}$ fat) and different duodenal conditions of $\mathrm{pH}$ and Bile concentration

Table 4.9. Total FFA (mg/g fat) obtained for the different meat matrices (hamburger, sausage, luncheon ham, pate, cured ham, cooked ham, chicken drum, pork loin and beef steak) after the in vitro digestion process using a fixed enzyme dose (2000 LU/g fat) and different duodenal conditions of $\mathrm{pH}$ and Bile concentration

Table 4.10. Linear mixed regression models explaining the association between the study variables. 130

Table 4.11. Matrix Degradation Index (\%) and Lipolysis extent (\%) of different cheeses (aged, mild, fresh goat and fresh cow) digested at fixed enzyme dose of $2000 \mathrm{LU} / \mathrm{g}$ fat and different duodenal conditions of $\mathrm{pH}$ and Bile concentration 149 
Table 4.12. Fatty acids profile obtained for the different cheese matrices (aged, mild, fresh goat and fresh cow) expressed as $\mathrm{g}$ of free fatty acid in $100 \mathrm{~g}$ of total fatty acids....

Table 4.13. Proteolysis parameters $\left(\triangle \mathrm{OD} / \mathrm{h}\right.$ and $\left.\mathrm{OD}_{\max }\right)$ obtained for the different cheese matrices (aged, mild, fresh goat and fresh cow) after the in vitro digestion process using a fixed enzyme dose of $2000 \mathrm{LU} / \mathrm{g}$ lipid $(\approx 175 ; 177 ; 194$ and $114 \mathrm{PU} / \mathrm{g}$ protein in aged, mild, fresh goat and fresh cow, respectively) and different duodenal conditions of $\mathrm{pH}$ (6 or 7 ) and Bile concentration (1 or $10 \mathrm{mmol} / \mathrm{L}$ ) 155

Table 4.14. Proteolysis parameters $\left(\Delta \mathrm{OD} / \mathrm{h}\right.$ and $\left.\mathrm{OD}_{\max }\right)$ obtained for the different cheese matrices (aged, mild, fresh goat and fresh cow) using different enzyme dose $(0,1000$, 2000, 3000 and $4000 \mathrm{LU} / \mathrm{g}$ lipids at fixed intestinal conditions of $\mathrm{pH} 6$ and Bile

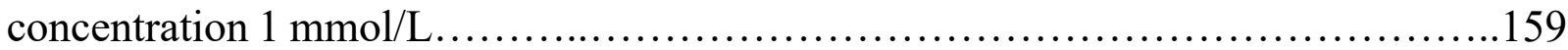

Table 4.15. Nutrient composition and water activity in raw, marinated and cooked salmon prior digestion

Table 4.16. F-ratio obtained from factorial ANOVA analysis for MDI (\%), proteolysis extent (\%), Lipolysis extent (\%) and Molar percentage of FA (\%). Factors included for the analysis were intestinal conditions and cooking method. The multifactor ANOVA was applied only to the data obtained at a fixed dose of 2000 LU/ g fat. 187 



\section{CONTEXT}

\section{MyCyFAPP Project}

The present doctoral thesis is framed in the context of an European Research and Innovation project funded by the Horizon 2020 program by the European Union: Innovative approach for self-management and social welfare of children with Cystic Fibrosis in Europe: development, validation and implementation of an mHealth tool (MyCyFAPP, REF. 643806, https://cordis.europa.eu/project/id/643806/es). This project was implemented from 2015 to 2018, with the integration of several research and innovation fields, including nutrition, food science and technology, gastroenterology, pediatrics, psychology, user centred-design, software engineering, ICT and mHealth.

The project was conceived with one main goal: to develop a Health tool to empower paediatric patients with Cystic Fibrosis (CF) and their families. One of the most interesting functionalities of the tool was a new evidence-based method that predicts the optimal dose of the supplement (Kreon ${ }^{\circledR}$, Mylan) according to the type of food, in every meal (Calvo-Lerma et al., 2017a). The reason behind was the lack of such a method and the negative consequences in the clinical treatment of pancreatic insufficiency derived from a wrong adjustment of the dose of the enzymatic supplements, including: abdominal pain, diarrhea, constipation, fat malabsorption, and growth stunting. The ultimate consequences of lacking of an accurate method to adjust the dose of enzyme supplements are a poor quality of life, decline in nutritional status, and thus, a worse disease prognosis and survival (Stephenson et al., 2013).

The vision of the final scenario consisted of a mobile app in which patients recorded the foods they were eating in a meal, and in real time the app showed the optimal dose of enzymes for that specific meal. In turn, these data would be synchronised with a professional web tool for the healthcare professionals in the hospital, enabling them to establish a close monitoring and follow-up. Overall, this system would empower patients' self-management of their treatment, improve feedback between patients and the hospital, and overall lead to improved nutritional status, quality of life and disease prognosis (Figure 1). 


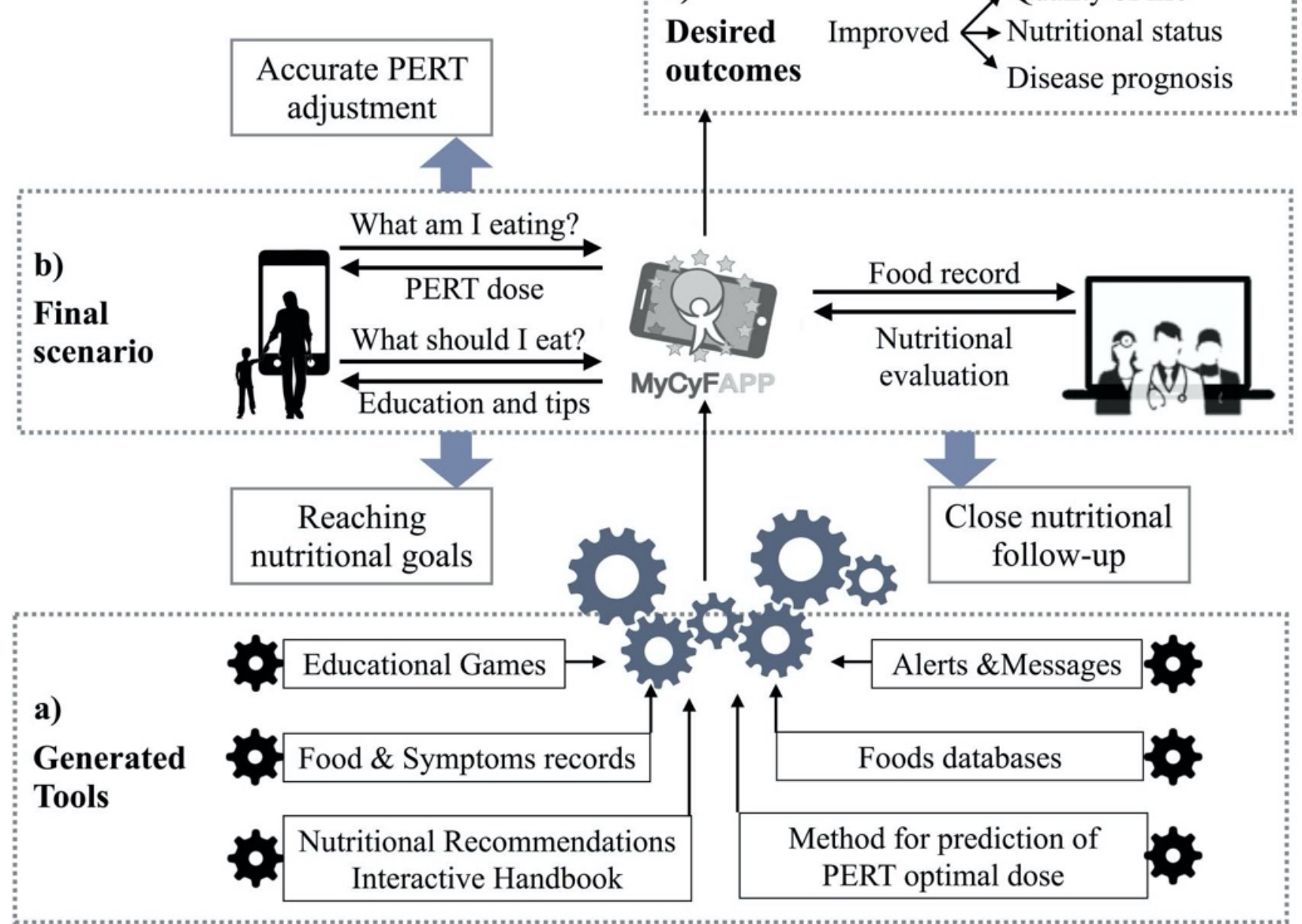

Figure 1. Summary of the project: generated tools (A), expected final scenario at the end of the project (B) and desired outcomes (C). Open-access figure extracted from Calvo-Lerma et al., $2017 \mathrm{a}$.

To address this challenge, MyCyFAPP project proposed a multidisciplinary and step-wise approach (Figure 2). This approached required a multi-actor consortium and the expertise from different research, development and innovation teams among Europe. In Table 1 the description of the consortium is provided. 


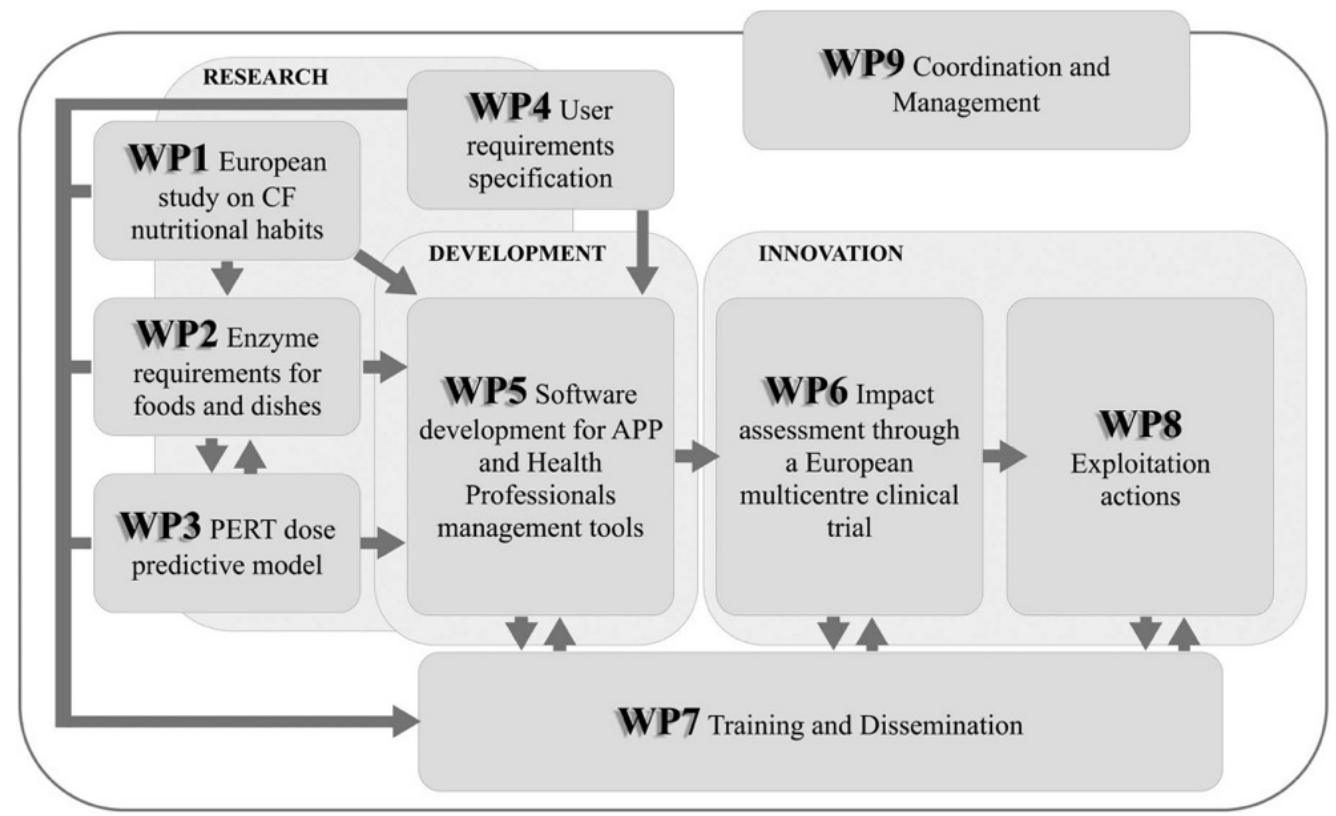

Figure 2. General overview and inter-relation of the different work-packages (WP) of the project. Open-access figure extracted from Calvo-Lerma et al., 2017a.

Table 1. The consortium of MyCyFAPP Project.

\begin{tabular}{|c|c|c|c|}
\hline Partner & Country & Discipline and expertise & Role in the project \\
\hline $\begin{array}{l}\text { Instituto de } \\
\text { Investigación } \\
\text { Sanitaria La Fe }\end{array}$ & $\begin{array}{l}\text { Valencia } \\
\text { (Spain) }\end{array}$ & $\begin{array}{l}\text { Clinical management of } \\
\text { pediatric patients with } \mathrm{CF}\end{array}$ & $\begin{array}{l}\text { Leader of the } \\
\text { Project. Leader of } \\
\text { WP3, WP7 and } \\
\text { WP9. Participant in } \\
\text { all WPs }\end{array}$ \\
\hline $\begin{array}{l}\text { Inst. Universitario de } \\
\text { Ingeniería de } \\
\text { Alimentos para el } \\
\text { Desarrollo (UPV) }\end{array}$ & $\begin{array}{l}\text { València } \\
\text { (Spain) }\end{array}$ & $\begin{array}{l}\text { In vitro digestion studies to } \\
\text { target nutrient digestibility. } \\
\text { Food Science and } \\
\text { Engineering }\end{array}$ & $\begin{array}{l}\text { Leader of WP2. } \\
\text { Participant in WP3, } \\
\text { WP7 and WP8. }\end{array}$ \\
\hline $\begin{array}{l}\text { Soluciones } \\
\text { tecnológicas para la } \\
\text { Salud y el bienestar } \\
\text { (UPV) }\end{array}$ & $\begin{array}{l}\text { València } \\
\text { (Spain) }\end{array}$ & $\begin{array}{l}\text { Software development for } \\
\text { technological tools } \\
\text { supporting } \\
\text { treatments }\end{array}$ & $\begin{array}{l}\text { Participant in WP4, } \\
\text { WP5 and WP8 }\end{array}$ \\
\hline
\end{tabular}




\begin{tabular}{|c|c|c|c|}
\hline Partner & Country & Discipline and expertise & Role in the project \\
\hline YOUSE GmbH & $\begin{array}{l}\text { Berlin } \\
\text { (Germany) }\end{array}$ & $\begin{array}{l}\text { User need's identification. } \\
\text { Application of the user- } \\
\text { centered design in research } \\
\text { projects }\end{array}$ & $\begin{array}{l}\text { Leader of WP4. } \\
\text { Participant in WP5 } \\
\text { and WP6 }\end{array}$ \\
\hline SINTEF & $\begin{array}{l}\text { Trondhaim } \\
\text { (Norway) }\end{array}$ & $\begin{array}{l}\text { ICT support in developing } \\
\text { software and devices to } \\
\text { improve clinical treatments }\end{array}$ & $\begin{array}{l}\text { Leader of WP5. } \\
\text { Participant in WP4 } \\
\text { and WP6 }\end{array}$ \\
\hline IMAGINARY & Milan (Italy) & $\begin{array}{l}\text { Serious games development } \\
\text { to support therapies }\end{array}$ & $\begin{array}{l}\text { Participant in WP4 } \\
\text { and WP5 }\end{array}$ \\
\hline UZ Leuven & $\begin{array}{l}\text { Leuven } \\
\text { (Belgium) }\end{array}$ & \multirow{5}{*}{$\begin{array}{l}\text { Leading CF Units in Europe } \\
\text { in terms of clinical } \\
\text { management and research }\end{array}$} & $\begin{array}{l}\text { Leader of WP6. } \\
\text { Participant in WP1, } \\
\text { WP3 and WP7 }\end{array}$ \\
\hline $\begin{array}{l}\text { Centro Hospitalar } \\
\text { Lisboa Norte }\end{array}$ & $\begin{array}{l}\text { Lisbon } \\
\text { (Portugal) }\end{array}$ & & $\begin{array}{l}\text { Leader of WP1. } \\
\text { Participant in WP6, } \\
\text { WP3 and WP7 }\end{array}$ \\
\hline $\begin{array}{l}\text { Erasmus MC } \\
\text { Sophia's Children } \\
\text { Hospital }\end{array}$ & $\begin{array}{l}\text { Rotterdam } \\
\text { (The } \\
\text { Netherlands) }\end{array}$ & & \multirow{3}{*}{$\begin{array}{l}\text { Participant in WP1, } \\
\text { WP3, WP6 and } \\
\text { WP7 }\end{array}$} \\
\hline $\begin{array}{l}\text { Ospedale Maggiore } \\
\text { Policlínico }\end{array}$ & Milan (Italy) & & \\
\hline $\begin{array}{l}\text { Hospital } \\
\text { Universitario Ramón } \\
\text { y Cajal }\end{array}$ & $\begin{array}{l}\text { Madrid } \\
\text { (Spain) }\end{array}$ & & \\
\hline CF Europe & $\begin{array}{l}\text { Brussels } \\
\text { (Belgium) }\end{array}$ & $\begin{array}{l}\text { European Federation of } \\
\text { National Associations for } \\
\mathrm{CF}\end{array}$ & $\begin{array}{l}\text { Participant in WP4, } \\
\text { WP6 and WP7 }\end{array}$ \\
\hline
\end{tabular}


The first stage of the project (Work-Package 1, WP1) was focused on assessing the nutritional habits and use of enzyme supplements in patients from different European CF Units. The objective of this initial research was to identify how patients adjusted the dose of enzymes according to the type of foods they had. The results revealed a lack of a common criterion among the different European countries along with high variability within the same patient regarding the enzymatic dose used for different meals (CalvoLerma et al., 2017 b; Calvo-Lerma et al., 2019). These results were aligned with other studies, showing similar results in children with $\mathrm{CF}$ from other regions in the world (Gelfond et al., 2018). Overall, this initial stage of the project highlighted the need of developing an evidence-based method to adjust the dose of enzyme supplements.

Following, WP2 used the ground information obtained from WP1 to set up an in vitro digestion model as the tool to investigate the optimal dose of enzyme supplements for every specific type of food. The most consumed foods and meals, previously identified in WP1, were classified into animal and vegetal origin. Only those containing amounts higher than $8 \%$ of fat were susceptible of being studied, as this is the most affected macronutrient by the altered gastrointestinal conditions occurring in $\mathrm{CF}$. The developed in vitro digestion model was designed by establishing the most representative alterations, as based on the available scientific literature in the field. Then, foods were subjected to the in vitro digestion process, and the digestions for all the studied foods were conducted by simulating different doses of enzyme supplements and combinations of altered intestinal conditions. The results were modelled and the "optimal dose of enzymes" for each studied food was established. Linked to a food recording system developed in another area of the project (WP5), the new evidencebased method to adjust the dose of enzymes was completed.

In a coming stage of the project, a preliminary pilot study consisted in translating the results of in vitro digestion studies to the in vivo scenario (WP3). To do so, a group of 207 patients followed during 24 hours the same fixed diet consisting of 6 meals and their corresponding recommended doses of enzymes, based on the results generated with the in vitro digestion model (Calvo-Lerma et al., 2019a). During the study period, patients collected faecal samples. Undigested fat found in faeces was determined, and 
overall, the coefficient of fat absorption was found to be $90 \%$, which confirmed the validity of the in vitro digestion approach (Calvo-Lerma et al., 2019b). With such prevalidation, the in vitro digestion studies were continued and expanded by simulating digestion to determine the optimal dose of enzymes in a wide range of food products.

In parallel to the described research actions, a specific area of the project worked on identifying the patients' needs regarding the design of the app in which the evidencebased method to adjust the dose of enzymes would be implemented (WP4). So, different workshops, interviews and simulations were conducted with the patients, their families and the health care professionals, overall conforming a co-creation process (Floch et al., 2020). When the evidence-based method to adjust the dose of enzymes was completed, and the software specifications were defined, the app was developed (WP5). At that point, a clinical trial involving 6 CF Units in Europe was conducted. In the trial, 170 paediatric patients with $\mathrm{CF}$ and their families used the app to adjust the dose of enzymes in every meal during 6 months (WP6). At the end of the clinical trial, quality of life improved (from an overall PedsQL-GI of 84 to 95/100) (Boon et al., 2020), and fat absorption increased in those patients with more severe fat malabsorption (from 85 to 94\%) (Calvo-Lerma et al., 2020c). In addition, from an ICT perspective evaluation, the app showed acceptance by the patients and their families, who rated it as useful to selfmange the adjustment of the enzyme supplements dose (Floch et al., 2020).

All along to the implementation of the project, the generated knowledge in the different areas and disciplines were published and disseminated (WP7), accounting for more than 40 papers released from the results of MyCyFAPP. In particular, from the area of food science and in vitro digestibility studies, a total of 20 scientific papers were published. A book chapter and a review paper summarise the main outcomes and detail the generated knowledge regarding lipid digestion depending on the food matrix characteristics and the gastrointestinal conditions (Heredia et al., 2021; Calvo-Lerma et al., 2020a). On the other hand, some of the generated results of the project were susceptible of being commercially exploitable, so a part of the project was devoted to identify and protect those results (WP8). Among them, the in vitro digestion-based methodology to predict the optimal dose of enzymes, was protected with intellectual 
property rights (in the Spanish Registry Office). This particular result was thereafter identified by the Innovation Radar of the European Commission as one of the products of the project with a high maturity level for market uptake (https://www.innoradar.eu/innovation/32948).

In particular, the present doctoral thesis includes part of the results generated in WP2, which implied a crucial input to the development of the evidence-based method to adjust the dose of enzymes and therefore to the successful outcomes of using the mobile app. Concretely the food group with lipids from animal origin are the focus of this thesis. The newly generated knowledge regarding digestion of this food group in CF represent the fundamental contents of this thesis.

The project concluded in December 2018 with all the objectives achieved, the recognition of the European Commission, and the operative and validated mobile app as a tangible result ready for market uptake.

\section{Cystic Fibrosis (CF) and Pancreatic Enzyme Replacement Therapy (PERT)}

$\mathrm{CF}$ is a recessive genetic disease caused by the defect in a transmembrane protein that transports chloride across the cellular membrane (CFTR). Reduced chloride transport leads to thick mucosal secretions that promote obstruction, colonization and failure or several organs and systems, especially lungs, pancreas and liver (Colombo \& Littlewood, 2011). In the case of the pancreas, the presence of thick mucus in the pancreatic duct can lead to its complete obstruction, impeding the secretion of bicarbonate and pancreatin to the duodenum. As lipid digestion mainly takes place in the duodenum and pancreatin is key for lipid hydrolysis, most of dietary triglycerides remain undigested, and consequently, unabsorbed (Figure 3). 
Functional pancreas

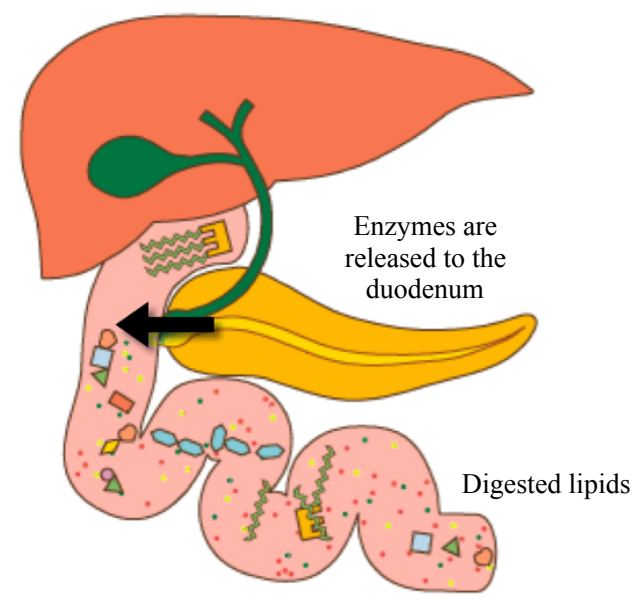

Exocrine pancreatic insufficiency

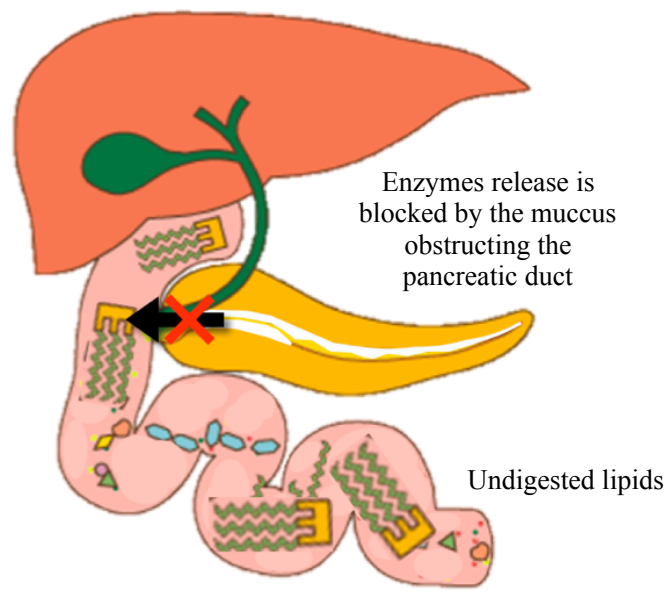

Figure 3. Difference in lipid digestion in the context of a functional pancreas and exocrine pancreatic insufficiency.

For this reason, the pillar in the nutritional treatment of $\mathrm{CF}$ is pancreatic enzyme replacement therapy (PERT). PERT consists of the oral administration of porcine-origin, encapsulated granules of pancreatin in every meal. The capsules contain protease (600 units), amylase (800 units) and mainly lipase (10.000 lipase units, LU). The capsules are made of a gel-based material that is rapidly disintegrated when in contact with the acidic fluids in the stomach, leaving the granules dispersed in the gastric content. The effectivity of the encapsulated pancreatin inside is preserved by the gastric-resistant enteric coat covering the granules. As digestion progresses, the granules pass through the pylorus along with the chyme and enter the duodenum. At that point, alkaline $\mathrm{pH}$ allows for the dissolution of the enteric coating. Then pancreatin, that has remained intact, is released and ready to exert its hydrolytic action (Domínguez-Muñoz, 2011). Despite the therapy succeeds in supplying a source of lipase to the intestinal tract, its effectivity remains continuously changing among patients (Rowbotham et al., 2018). 


\section{Dosage Criteria in PERT: MyCyFAPP Approach}

The need of administrating pancreatin supplements raises the question about the optimal dose that should be supplied. Despite the in force clinical guidelines of nutrition in CF (from 2016) recommend a dose between 2000 and 4000 LU per gram of dietary fat in every meal, the degree of evidence to make this recommendation was acknowledged to be "very low". Before Mycyfapp project, studies in the field could not find any evidence explaining the relationship between the dose of enzyme supplements and other physiological outcomes, such as presence of undigested fat in faecal samples, or weight gain (Woestenenk et al., 2015). Noteworthy, none of those studies considered the type and characteristics of foods consumed by those patients. In fact, the low evidence degree for the recommendation and the lack of scientific valid methods to adjust the dose, depicted a wide spectrum in the criteria among European CF centers to recommend dose adjustment (Calvo-Lerma et al., 2017). Authors found that in some centers the mean doses could be around $1500 \mathrm{LU} / \mathrm{g}$ day while in others it could be as high as $7800 \mathrm{LU} / \mathrm{g}$ day. These findings reinforced the need of conducting such a project as MyCyFAPP.

The approach towards an evidence based-method to adjust the dose of the enzymatic supplements started with the hypothesis that different factors should be considered: the specific physiological conditions of the CF patients (reduction of duodenal $\mathrm{pH}$, bile concentration and low or nule pancreatic enzymes) and the dietary factors (food composition, matrix structure, processing conditions and interactions between foods consumed in the same meal). The study of the impact of all these factors and their interactions was considered the key to adjust the enzyme dose to obtain the optimal hydrolytic action of the enzyme supplements and the subsequent absorption of the products of lipolysis. The in vitro digestion method was proposed as the most useful tool to deal with that aim. In vitro studies consist on the simulation of the physiological process of digestion in the laboratory. They allow for screening different samples simultaneously, enabling experimental designs that assess the food matrix effect as well as the gastrointestinal scenario implications. They have the advantages of cost, 
reproducibility, sampling points, and processes to monitor, among others (Minekus et al., 2014). In the last decade, static or dynamic in vitro digestion protocols have been largely used to understand the process and the fate of food in the gastrointestinal tract. Static methodologies consist of placing the food in a bioreactor and simulating the gastrointestinal environment in each digestion compartment keeping constant the $\mathrm{pH}$ at each digestion stage, enzyme concentrations and bile salts concentration during the whole digestion process. Contrarily, dynamic models allow the $\mathrm{pH}$ regulation, the food and fluids flow simulation and the progressive release of the digestive enzymes in the different stages of the digestion system. Although dynamic methodologies are more expensive than static ones, they mimic the digestive process with more accuracy. Both static and dynamic methodologies present certain advantages and disadvantages. Static protocols have some limitations since the gastric and intestinal emptying cannot be simulated and the $\mathrm{pH}$, enzyme and bile salts concentration are constant in each digestive stage. However, static methodologies allow to study several samples at the same time and are financially affordable.

In vitro digestion studies were conducted by simulating different scenarios, and the optimal dose of enzyme supplements for each studied food was defined. Predicted doses were in all cases within the range of 1000 to $4000 \mathrm{LU} / \mathrm{g}$ of fat.

As previously explained, the core part of the self-management app would consist of an optimal dose of enzyme dose prediction tool, so that the patients indicated the foods they were going to eat and the app would indicate the recommended dose of enzymes for that specific meal (Figure 4). It was developed thanks to the generation of results by the in vitro digestion studies, which eventually defined the optimal dose of enzymes for all the types of fat-containing foods. In this prediction tool, thus, the main element was a database including a "theoretical optimal dose" of enzyme supplements (TOD) and the content of fat ( $\mathrm{g}$ fat $/ 100 \mathrm{~g}$ of food) for all the food items (A). The TOD was expressed as lipase units (LU) per gram of dietary fat. The TOD database ran in the background of the "food recording" feature so that when consumed food items and quantity in a meal were reported by the patient (B), a summation of the individual TOD for the consumed amount of each food item was done $(\mathrm{C})$. Once a whole meal was registered, the app 
displayed the predicted optimal dose of enzymes for that specific meal in terms of LU, along with the dose expressed as number of PERT capsules needed (D). Then, patients had to indicate the dose actually taken for each specific meal.

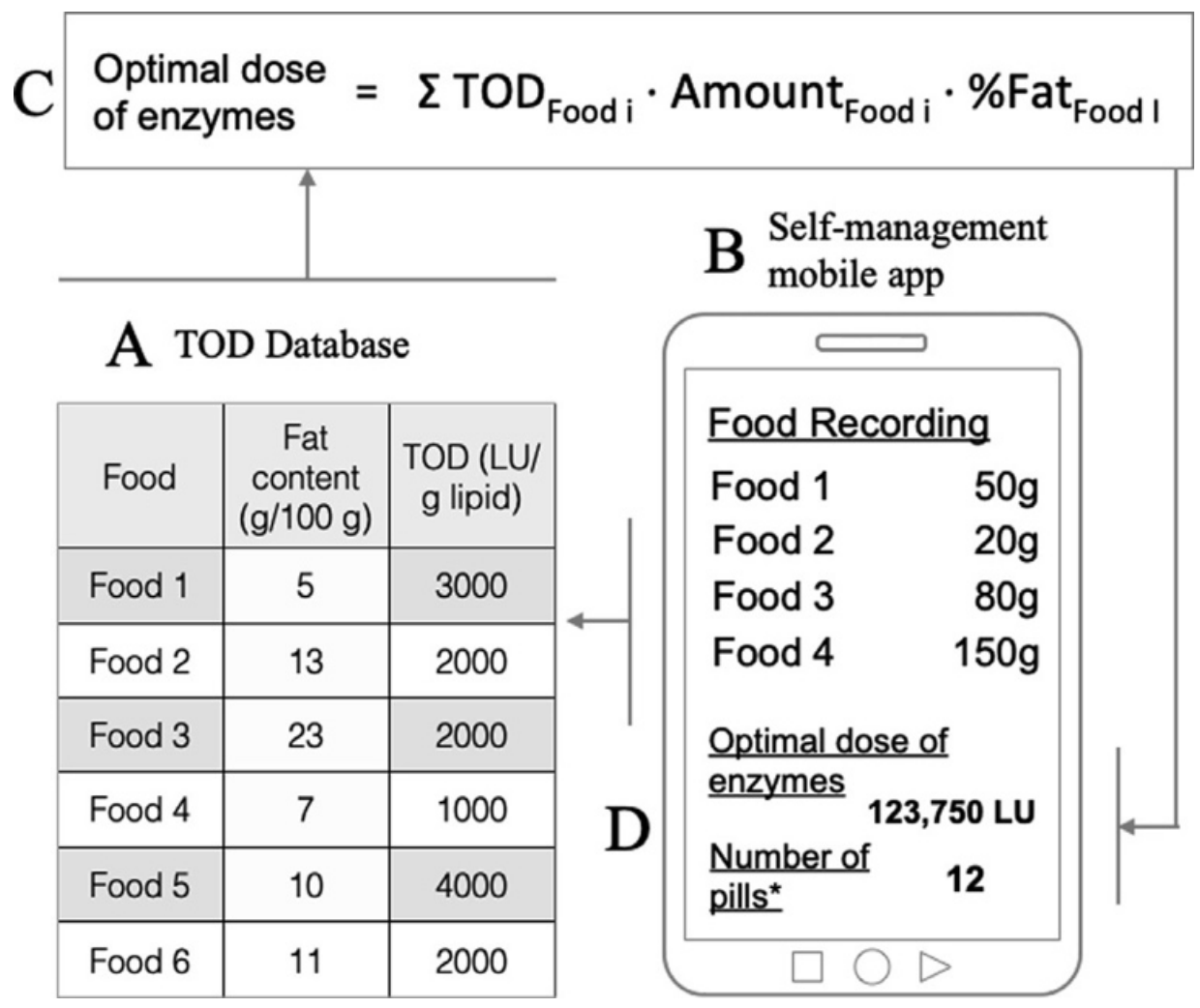

Figure 4. Schematic overview of the components supporting the prediction of the optimal dose of enzyme supplements. The core item is the Theoretical optimal dose database, in which all foods regularly consumed are assigned with a TOD value in $\mathrm{LU} / \mathrm{g}$ fat.

As anticipated, after using this evidence-based method to adjust the dose of enzymatic supplements during 6 months, patients with CF showed a median coefficient of fat absorption of $96.4 \%$, which is equivalent to the fat absorption extent found in healthy individuals. Interestingly, those patients with the poorest fat absorption at study baseline, experimented a statistically significant improvement (Figure 5 a). Thus, a change in the pattern of enzyme supplements administration supporting improvement in fat malabsorption was also documented: the interquartile range of the median dose of enzymes at the end of the study was significantly reduced from 1447-3070 LU/g fat to 1783-2495 LU/g fat (Figure 5 b) (Calvo-Lerma et al., 2020b). Therefore, MyCyFAPP 
project was concluded with satisfactory results, as the generated dosing criterion to adjust the dose of enzyme supplements led to improved fat absorption.
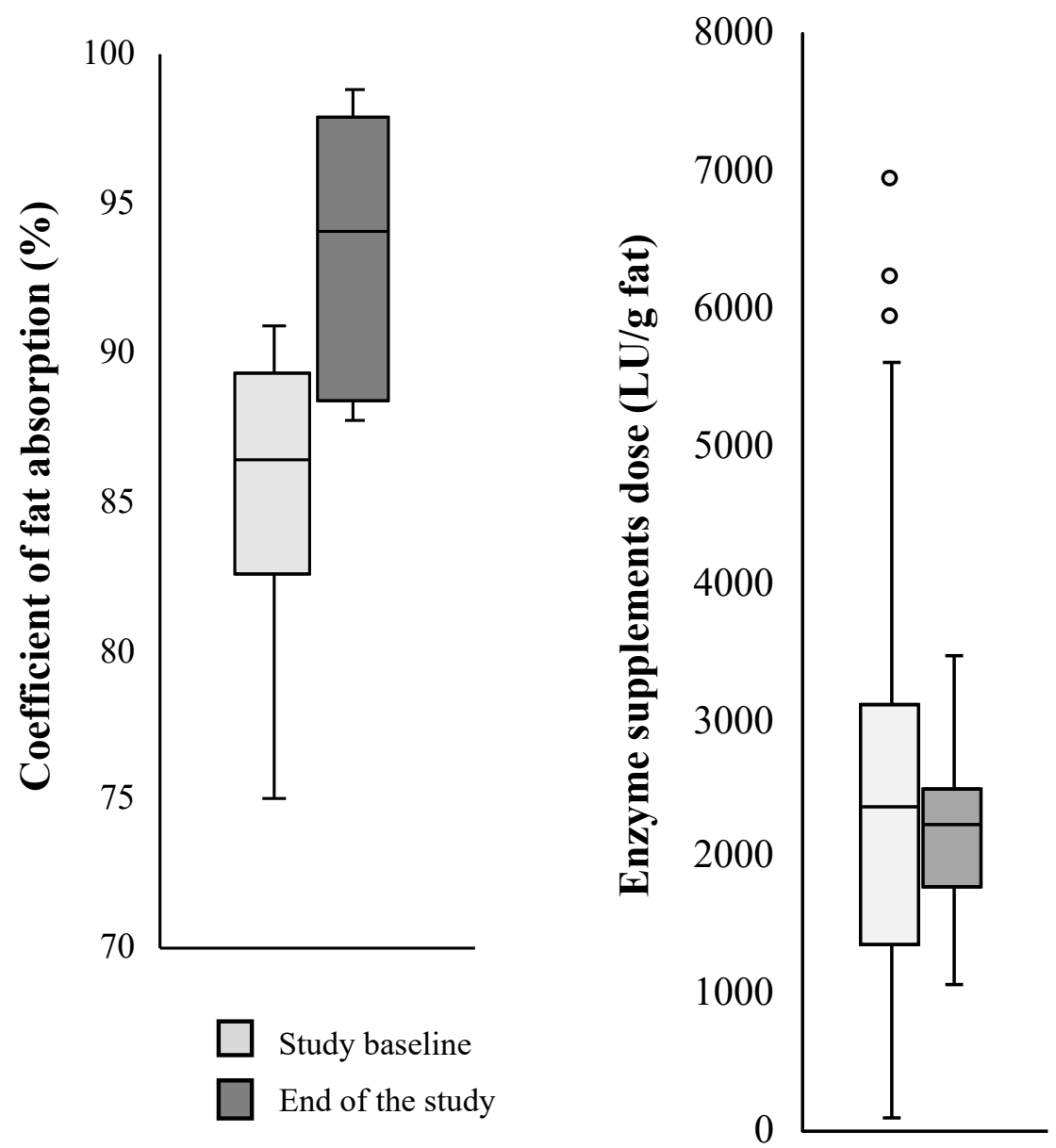

Figure 5. Change in coefficient of fat absorption (right) and enzyme supplements dose (left) at the end of the MyCyFAPP clinical trial study period compared to the study baseline, after using the evidence-based method to adjust the dose of enzyme supplements during 6 months (CalvoLerma et al., 2020b). 


\section{INTRODUCTION}




\section{INTRODUCTION}

As above contextualised, the present thesis focuses on studying the digestion of a suite of food products containing lipids of animal origin taking into account the altered intestinal conditions occurring in Cystic Fibrosis (CF). Understanding food digestion requires to overview the digestion process, the digestion and absorption of food nutrients and highlighting the main factors involved.

\subsection{Food Digestion}

\section{Digestion process}

Digestion is a complex process that consists of the disintegration of food structure allowing the release of macronutrients and the hydrolysis of lipids, proteins and carbohydrates in small molecules that are absorbable by the organism. Digestion also implies the solubilization of other components such as micronutrients, toxics and bioactive compounds as polyphenols and carotenoids. The digestive process starts in the mouth, and follows in the stomach and the small and large intestine, where the largest extent of food digestion occurs. The biological function that the digestion process contributes to is to allow the availability of nutrients to the epithelial cells, so nutrients pass to the circulatory system and are distributed to the corresponding organs and tissues to exert its function. The founding of digestion is step-wise: first the food matrix disruption enables nutrient release to the digestion medium. Then, released nutrients become accessible to the digestive enzymes that break them down into simpler molecules that can be eventually absorbed. The digestion process occurs in four main steps as follows:

\section{Oral stage}

Digestion starts in the mouth where food is mixed with the saliva and chewed by teeth (Figure 1.1). Mastication provides the mechanical force that contributes the most to the degradation of the food matrix, and allows for mixing the resulting particles with the salivary secretions. In case of solids, chewing produces the reduction of the particle 
size $(0.3-3 \mathrm{~mm})$ before oral bolus formation (Fontijn-Tekamp et al., 2004). Liquids, however, require a minimal time in mouth and they are diluted by the saliva and temperature is regulated when are ingested (Minekus et al., 2014). Dentition, tongue, muscles and joints are different elements that conform the mouth structure. During mastication the mandible moves vertically and horizontally according to the signals regulated by the central nervous system. Moreover, food intake involves different mechanisms related to the enjoyment and pleasure of eating and drinking. The nervous system also indicates when the bolus is ready to be swallowed. In this sense, different types of food have been characterised in terms of number of mastication cycles required before the bolus is ready for swallowing, the spectrum ranging from 55 in the case of peanut (Van der Bilt, Engelen, Abbink \& Pereira, 2007) to 27 in cheese (Gaviaõ, Engelen $\&$ van der Bilt, 2004). Both the structural properties of the food matrices and the nutrient and moisture composition are known to be the determinants of the required mastication regimes.

Saliva is a viscous fluid that is secreted by the salivary glands, containing $99.5 \%$ of water, $0.3 \%$ of proteins and enzymes, and $0.2 \%$ of different electrolytes such as sodium $\left(\mathrm{Na}^{+}\right)$, potassium $\left(\mathrm{K}^{+}\right)$, magnesium $\left(\mathrm{Mg}^{2+}\right)$, calcium $\left(\mathrm{Ca}^{2+}\right)$, and nitrogenous products (Li, 2020; Salles, 2011). These different components play an important role in the organism. For example, bicarbonates, phosphates and urea modulate the $\mathrm{pH}$ and the buffering capacity of saliva. In case of proteins, especially mucin, clean and protect the oral cavity from microorganisms and contribute to the plaque metabolism. Dental mineralisation reactions are modulated by calcium phosphate and proteins, and immunoglobulins provide the antibacterial power. Oral microbiota plays also an important role during digestion. Concretely, Calatayud et al., (2018) studied the relevance of adding oral microbiota for the simulation of the gastrointestinal digestion. According to the study, arsenic absorption was increased at small intestine when food matrices were digested with salivary bacteria. These results highlight the importance of including oral microbiota in studies addressing the digestion of real food matrices. 
Immunoglobulin A, lysozyme, lactoferrin and mucins are the main proteins which saliva presents. The composition and the flow rate of the saliva are not only influenced by the food properties, but also by physiological host factors (Salles et al., 2011).

The daily content of secreted saliva ranges between 0.5 and $1.5 \mathrm{~L}$ in healthy people. Salivary flow in healthy adults is approximately $0.3 \mathrm{~mL} / \mathrm{min}$ when is unstimulated, but the secretion increases to 1 and $2 \mathrm{~mL} / \mathrm{min}$ when a stimulus is present (Sreebny, 2000), and depending on the type of food, volumetric flow rates of 7-8 $\mathrm{mL} / \mathrm{min}$ have been reported, as in the case of bread and cakes (Gaviaõ, Engelen \& van der Bilt, 2004) or carrots (Watanabe \& Dawes, 1988). Overall, during the oral phase the salivary fluid:food ratios $(\mathrm{v} / \mathrm{w})$ result in a range between 0.4 and 8.8 (Gaviaõ, Engelen \& van der Bilt, 2004; Brudevold, Kashket \& Kent, 1990; Watanabe \& Dawes, 1988). The main enzyme that is present in the salivary fluid is alpha-amylase, which is usually present in the concentration of $45 \mathrm{U} / \mathrm{mL}$ (Neyraud et al., 2012).

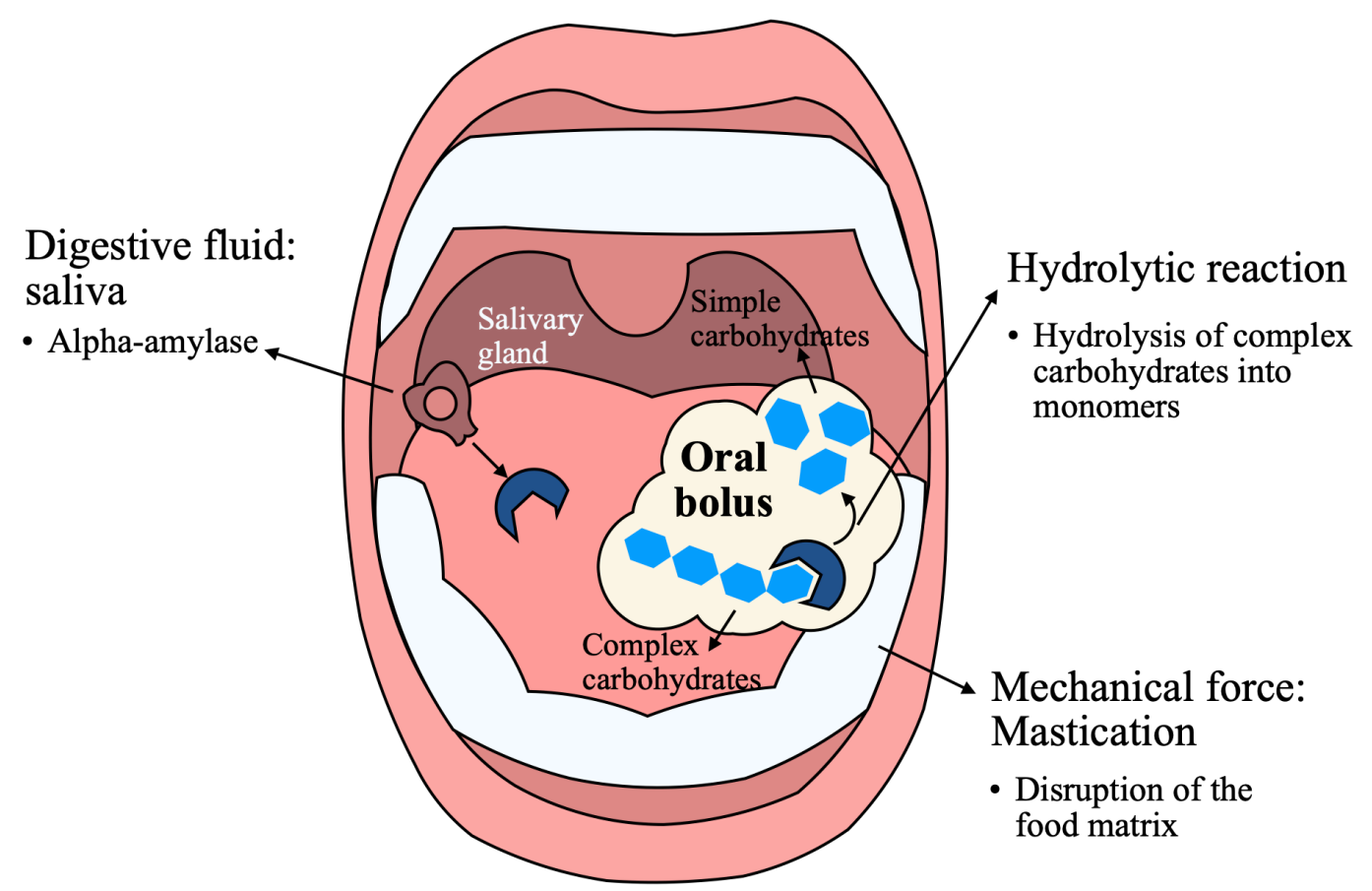

Figure 1.1. Overview of the main processes and enzymatic reactions occurring at the oral stage.

\section{Gastric stage}

The stomach is the organ involved in gastric digestion and is where the food hydrolysis starts under acid conditions (Figure 1.2). Stomach presents four sections: the 
fundus, the body, the antrum and the pylorus. The different parts of the stomach play a crucial role in the gastric digestion process. The fundus and body mainly act as a reservoir for non-digested food, while the antrum is responsible for grinding and mix the solid food particles and pump them for the gastric emptying through the pylorus (Marciani et al., 2008; Marciani et al., 2000).

The size of the stomach varies depending of the food intake. Under fasting conditions, the stomach has a small volume $(10-40 \mathrm{~mL})$ and it can extend to $1.5-4 \mathrm{~L}$ for large amount of food (Norton et al., 2014). The gastric emptying is determinant for glycaemic response. Lower gastric emptying rate provoke a slower release of food into the small intestine where the most of the starch is absorbed. The gastric emptying rate depends of the food physiochemical properties in terms of viscosity, state (solid or liquid), particle size, and energy density or macronutrient composition. Liquids and small food particles pass to the small intestine more quickly than the larger ones. Solid food sized particle needs to be reduced to $2 \mathrm{~mm}$ in order to pass through the pylorus into the small intestine. The time required to empty whole the stomach varies depending of the food properties (Norton et al., 2014) being usually between $3-5$ hours.

Regarding enzymes involved in gastric digestion, once the oral bolus has reached the stomach, pepsinogen and gastric lipase are secreted by the chief cells and the hydrochloric acid by the parietal cells. The decrease of $\mathrm{pH}$ during digestion takes several hours. Immediately after food intake, the gastric $\mathrm{pH}$ is mainly dominated by the $\mathrm{pH}$ of food (Amara et al., 2019). For this reason, the stomach $\mathrm{pH}$, which is around 2 in the fasting state, rapidly increases to 6 , due to the buffering effect of the oral bolus. However, the gastric secretions together with the gastric emptying cause a progressive decrease of $\mathrm{pH}$, reaching values close to 3 after 120 minutes of gastric digestion (Sam et al., 2015). 


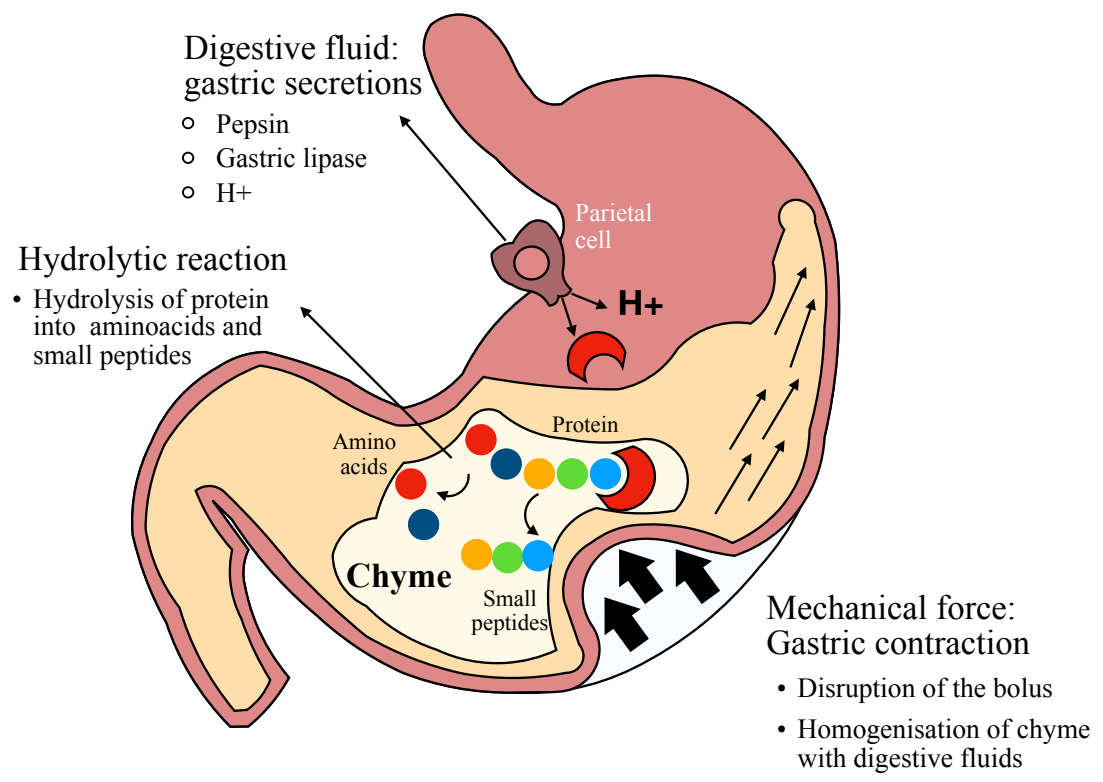

Figure 1.2. Overview of the main processes and enzymatic reactions occurring at the gastric stage.

\section{Small intestinal stage}

Once the chyme passes to the duodenum (the first segment of the small intestine), the poured pancreatic juice and the bicarbonate secretion produced by the pancreas start the intestinal digestion (Kalantzi et al., 2006). Anatomically, the small intestine consists of three parts with different length: duodenum $(0.25-0.3 \mathrm{~m})$, jejunum $(1.22 \mathrm{~m})$ and ileum $(1.52 \mathrm{~m})$ (Hadley, 2012). The digestion process occurs mainly in the duodenum, whereas nutrient absorption takes place in the jejunum and the ileum (Figure 1.3).

Chyme is transported through the duodenum due to the peristaltic movements and muscle contraction. These mechanisms are regulated by the myogenic, neural and hormonal reactions. The neural system includes the autonomic and enteric nervous systems and both control the movements and the hormonal secretions (Campbell et al., 2019), concretely gastrin, secretin and glucagon are the hormones affecting the most in the small intestine mobility. Mobility continues under fasting state to transport the undigested food into the colon for fermentation.

There are some organs involved in the digestion process, being the pancreas and the gallbladder the most relevant. Pancreatin and bicarbonate are secreted by the 
pancreas, while bile salts by the gallbladder, and poured into the intestine through the biliary duct. Pancreatin is a complex mixture of enzymes (mainly proteases, lipases and amylases). The bicarbonate secretion causes the increase of $\mathrm{pH}$ in the resulting mixture from the stomach (i.e., the chyle) up to $\mathrm{pH}$ between 7 and 7.5 (Aburub et al., 2018). In this scenario, both alpha-amylase and gastric lipase can play a role in the digestion, while pepsin is completely inactivated.

Regarding the different enzymes that are present in pancreatin, the majority of proteases are trypsin and chymotrypsin among others in lower amounts such as elastase, carboxypeptidase and other peptidases. Pancreatic amylase is also present in prancreatin, concretely an alpha-amylase enzyme which catalyse the starch hydrolysis into simple carbohydrates. Pancreatin also contains pancreatic lipase, which conducts lipid hydrolysis.

The wall of the small intestine is composed by four layers: mucosa, submucosa, muscularis propria and serosa. The mucosa is the layer where absorption of nutrients and water from lumen takes place thanks to the presence of specific structures, including: crypts (intestinal glands), villi and microvilli, this surface being also known as the brushborder. These intestinal microvilli vary in length from 100 to $2000 \mathrm{~nm}$, and their disposal allows for greatly increasing the absorption surface in the small intestine, which confers the appearance of a "brush-border". Apart from the enzymes contained in pancreatin, the brush-border secretes very specific hydrolytic enzymes that contribute to final breakdown of macronutrients, especially carbohydrates, close to the absorption sites.

The intestinal epithelial cells are produced at the base of crypts and after 3 or 5 days they migrate to the villi. Crypt cells are responsible of mitosis and the secretion of electrolytes and fluids. During this period of time, the cells are also differentiated into three cell types, including enterocytes (the common absorptive cells), the goblet cells (the responsible of mucin secretion) and endocrine cells (responsible of the detection of different nutrients and secretion of gastrointestinal hormones) (Mackie, 2019). The differentiation of these cells allows for the eventual nutrient absorption. 


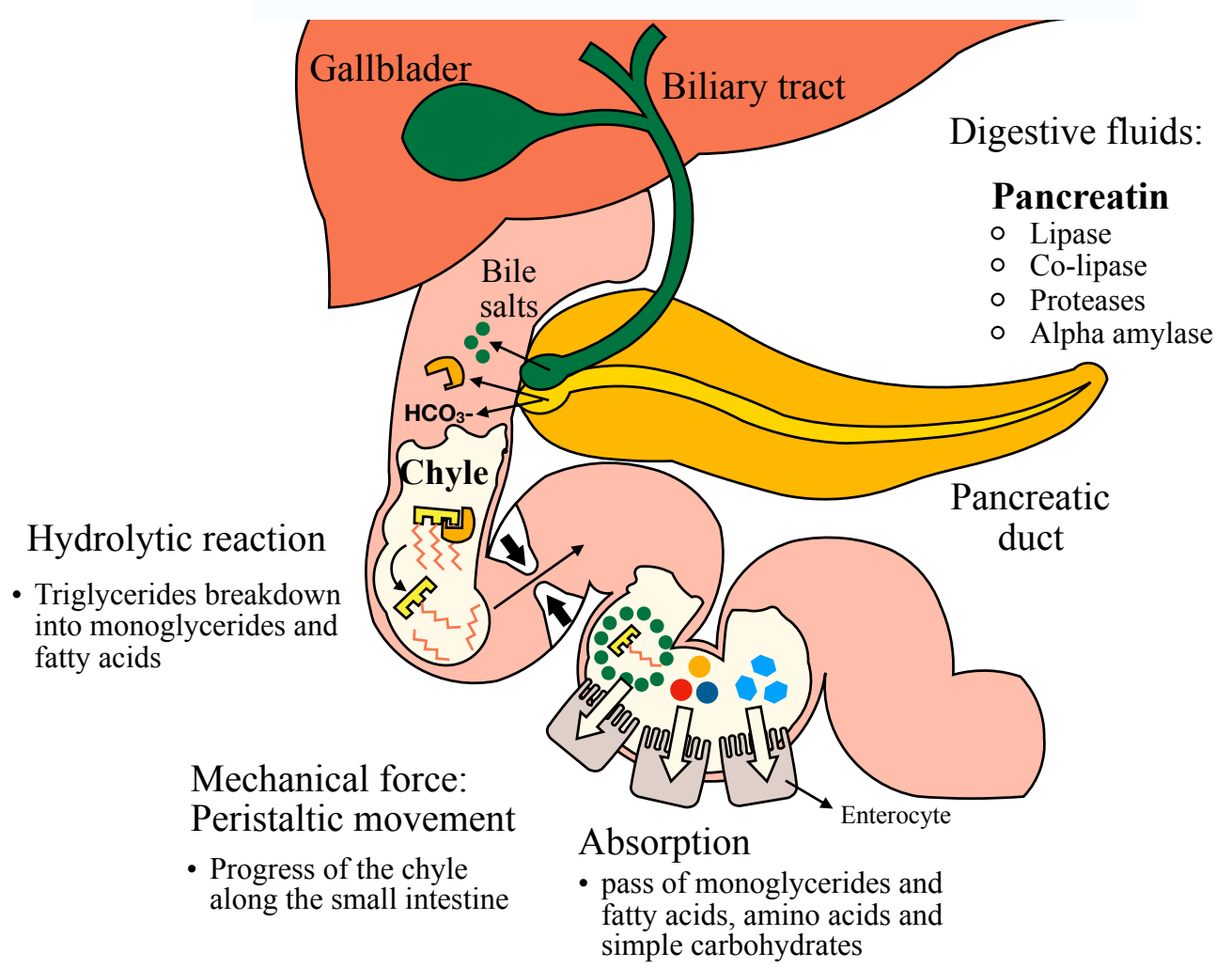

Figure 1.3. Overview of the main processes and enzymatic reactions occurring at the small intestinal stage.

\section{Colonic stage}

The last part of the digestive system is the large intestine or colon, which is divided into ascending, transverse and descending colon. Digestive mechanisms at this stage are largely conditioned by the presence of colonies of microorganisms, namely the microbiota (Figure 1.4). The colon is a complex microbial ecosystem in which the microbiota includes thousands of different bacterial species, subspecies and biotypes. The composition of microbiota depends on the many factors related to the host (i) (genetics, digestive secretions, digestive physiology, age, immunity, diet, diseases, drugs and antibiotics intake), microbiome behaviour (ii) (competition for nutrients and adhesion sites, metabolic cooperation and bacterial antagonism) and colon environment (iii) (substrate availability and pH) (Macfarlane \& Macfarlane, 2012).

The metabolic reactions occurring during the colonic digestion have an impact on the individual health. Colonic microbiota is able to hydrolyse some complex carbohydrates (fibre) and parts of proteins that have not been absorbed in the small intestine. The principal products from carbohydrate fermentation by the microbiota are 
short chain fatty acids (SCFA)s, which have multitude of beneficial effects in the human health. SCFAs production influences the epithelial cell transport, metabolism, epithelial cell grown and differentiation. They also have an effect on the hepatic control of lipids and carbohydrates, and also supplies energy for muscles and kidneys, heart and brain (Cummings, 1995). In the same way, proteins and peptides can be also hydrolysed by colonic microorganisms. The hydrolytic products serve as carbon and nitrogen sources to the microbiota. The enzymes secreted during the gastric and intestinal digestion can be also used by the bacteria community as protein sources. Most of the metabolites obtained from microbiota are absorbed in the colon.

Another relevant function of this part of the digestive system is related to water absorption. Digesta at this stage undertakes the major removal of water amount, resulting in a residue or faecal product, that is eventually excreted as faeces, representing the end of digestion.

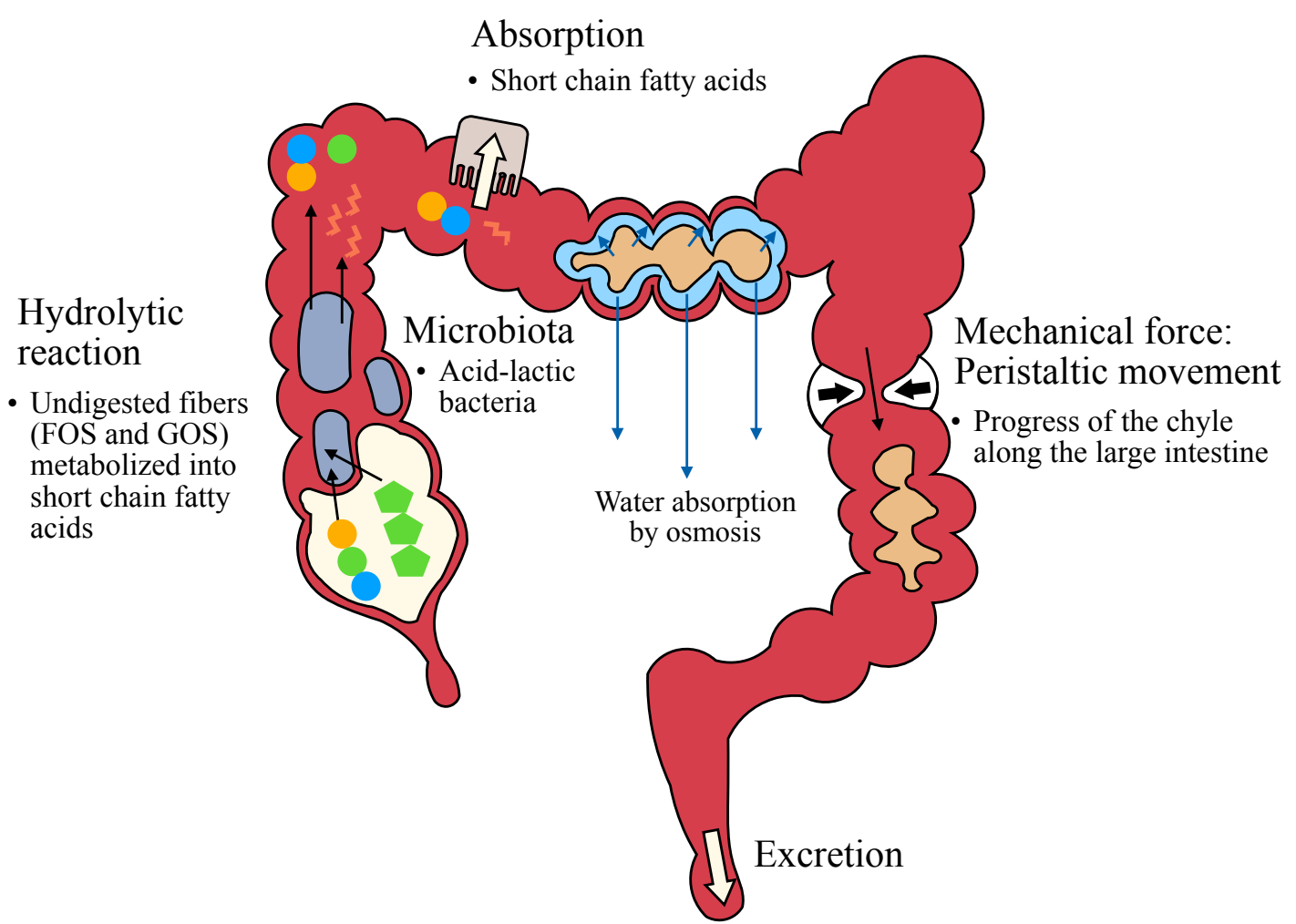

Figure 1.4. Overview of the main processes and enzymatic reactions occurring at the large intestinal stage. 


\section{Digestion and absorption of nutrients}

The digestion of foods results in the hydrolysis of macronutrients and the release of bioactive compounds thanks to the physical (peristaltic movements), chemical ( $\mathrm{pH}$ ) and biochemical agents (enzymes in the digestion fluids) supporting the physiological gastrointestinal digestion process. The resulting molecules after hydrolysis can be absorbed in the small intestinal. Water and nutrients are absorbed by enterocytes by simple diffusion, facilitated diffusion or active transport.

\section{Carbohydrates}

Of the three macronutrients, carbohydrates can be divided into two groups: simple and complex. The simple carbohydrates are in turn divided into monosaccharides (glucose, fructose, galactose and maltose) which are the most basic unit or monomers of carbohydrates, and can be absorbed. Then, disaccharides are molecules formed by two monosaccharides joined by an O-glycosidic bond. Examples include lactose (glucose+galacatose) or sucrose (glucose+fructose). Among the complex carbohydrates, starch and glycogen are the main representatives from vegetal and animal origin respectively. These polysaccharides are long chains of monosaccharides encompassed by glycosidic bonds. For carbohydrates being absorbed, hydrolytic reactions to deliver monosaccharide structures are required, by means of which the glycosidic bonds are broken down. The process of carbohydrates hydrolysis or digestion is known as glycolysis. The responsible enzymes to exert this hydrolysis are the amylases. In the human digestion, amylases are present in the salivary secretions and then in the pancreatic juice (Dona et al., 2010). Therefore, carbohydrates hydrolysis starts in the oral stage, thanks to the mixing of saliva with the food, resulting in the bolus. As the permanence of the food at this stage is brief, oral stage accounts for a low proportion of total glycolysis. However, salivary amylase is also present in the stomach since it remains in the swallowed oral bolus. In the beginning of the gastric digestion, alphaamylase can remain active for a period beyond the oral stage, but considering its optimal $\mathrm{pH}$ is around $6.5-7$. However, over time, the combination of pepsin secretion and the decrease of the $\mathrm{pH}$ cause the loss of enzyme activity. Glycolysis is resumed in the small 
intestine, thanks to the action of the pancreatic alfa-amylases and maltase, which are responsible for the largest extent of carbohydrate digestion.

Pancreatic amylase is the main enzyme implied at the luminal digestion. The enzyme structure contains three domains at the $\mathrm{N}$-terminal (A, B and C). The A domain is where the active site is located, while B domain is where the calcium is bound and the C domain has an unknown function (Brayer et al., 1995). Maltases enzymes are located in the brush-border and hydrolyse the disaccharide maltose to simple glucose. Other disaccharides or oligosaccharides are not hydrolysed by amylases or maltases, but by enzymes secreted at the gut absorption surface, such as alpha-dextrins or glycosidases. Monosaccharides need to be absorbed by active transport and it is occurring due to a low intracellular sodium concentration that implies the necessary gradient to transport from the lumen into the enterocyte. The rate of absorption of glucose and galactose, however, is limited because both compete for the same sodium coupled-carrier. In case of fructose, is absorbed by facilitated diffusion (Campbell et al., 2019). At this stage, the resulting monomers are absorbed across the enterocyte membrane, causing an increase in the glycaemic index, the amount of glucose in the bloodstream, until they are introduced into the cells of tissues and organs, thanks to the action of insulin, and further utilised as energy sources. Conversely, those non-digestible carbohydrates, e.g., the dietary fibres, pass to the colon, where are used as substrates by the microbiota (fermentation), resulting in the production of short chain fatty acids, that can also be absorbed in the colon.

\section{Proteins}

Proteins are molecules characterised by the presence of nitrogen. All of them share the same core structure, which is an amino acid chain bended in a three-dimensional structure. The basic units or amino acids, are characterised by a central carbon to which a carboxylic $(\mathrm{COOH})$ and an amino group $\left(\mathrm{NH}_{2}\right)$ are joined, besides a $\mathrm{R}$ chain, whose structure defines the type of amino acid, among a total of 20 which are aminoacids conforming food proteins. In the protein molecule, amino acids are joined by covalent peptidic bonds. The composition in amino acids is what differentiates proteins. Therefore, for proteins being absorbed, the peptidic bonds have to be hydrolysed, and 
proteases are the enzymes committed to this function. Through the process of digestion, the gastric and the intestinal stages secrete the fluids containing different types of proteases. The gastric secretions contain pepsinogen, the precursor of pepsin, which is activated in presence of acid $\mathrm{pH}$ (1.5-5) giving rise to pepsin, an aspartic protease with preference by the $\mathrm{N}$-terminal of aromatic amino acids. This enzyme contributes to the release of peptides, smaller structures than proteins formed by a small number of amino acids, and also some free amino acids. Then, the trypsin, chymotrypsin and carboxypeptidase are the main proteases in the pancreatic secretion, exerting further breakdown of protein and peptides into amino acids in the intestinal stage. Trypsin is secreted as a trypsinogen in order to protect the pancreas and pancreatic duct, and needs to be activated by enterokinase to trypsin. Then, trypsin activates other proenzymes (chymotrypsogen, proelastase and carboxypeptidase) into chymotrypsin, elastase and carboxypeptidase. Trypsin is mainly active at the C-terminal side of the amino acids, lysine and arginine. While chymotrypsin prefers to cleave the C-terminal side of hydrophobic amino acids such as tryptophan, tyrosine and phenylalanine (Mackie, 2019). As in the case of carbohydrates, some proteases, such as the aminopeptidases, are secreted by the brush-border cells at the surface of the intestinal cells, which complete the proteolysis of some peptides (tetrapeptides, pentapeptides and hexapeptides). Then amino acids (and some short-chain peptides) are absorbed through active transport. The most of protein absorption occurs at the jejunum.

\section{Lipids}

Lipids are presented in different molecular structures in foods. Among them, phospholipids or free fatty acids are present, but the main (>95\%) are in the form of triglyceride, which is a glycerol backbone to which three chains of fatty acids are attached by steric bonds. The glycerol structures to which fatty acids are bonded are known as the stereospecific positions sn-1, sn-2 and sn-3. There are different types of fatty acids in terms of chain length or number of carbons (most of the dietary fatty acids are long-chain, i.e., with more than 14 carbon atoms) and the number of double bonds within the chain, or number of unsaturations (saturated having no double bonds, 
monounsaturated having one and polyunsaturated more than one). So, in order for triglycerides to be broken down for absorption, the steric bonds have to be hydrolysed by the action of lipases. Lipases are water-soluble ester hydrolases and are defined by their preference to apolar substrates that are water-insoluble. This group of enzymes also includes colipase and cholesterol esterase. The hydrolysis of the triglyceride molecule can result in the release of three fatty acids and one glycerol molecule apart (full lipolysis), or in partial species such as a monoglycerol (one fatty acid remains attached to the glycerol) + two free fatty acids, or a diglycerol (only one fatty acid is released). However, only monoglycerols and free fatty acids can be eventually absorbed by the enterocyte.

Two types of lipases are responsible for conducting lipolysis in the digestion process: gastric and pancreatic lipases. Gastric lipase is secreted into the stomach by the chief cell. This enzyme is stable in acidic conditions as those occurring in the stomach environment, being active between a $\mathrm{pH}$ ranging from 3 to 6 and its optimal $\mathrm{pH}$ is between 4.5-5.4 (Sams et al., 2016). In turn, the gastric lipase hydrolyses around 10-25 $\%$ of the ingested triglycerides in diglycerides and fatty acids (Troncoso \& Aguilera, 2009) and has preference for the sn-3 position in the triglyceride. This enzyme starts the lipid digestion, which continues in the small intestine.

Among the hydrolytic processes occurring in duodenum, lipolysis is the most complex, as it requires the presence of different agents (surfactants, co-factors, etc.) and the optimal digestion environment conditions for the activity of pancreatic lipase. First, the presence of bile salts allows the formation of a colloidal system, in which dietary lipids are emulsified in the digestion medium. Then, the pancreatic lipase can access the surface of emulsified fats in presence of colipase. The presence of colipase, a protein cofactor, is necessary to get the optimal activity of pancreatic lipase. When colipase is secreted at duodenum is activated by the trypsin. The main objective is to prevent the inhibition effect of the bile salts on the lipase. Thus, lipid hydrolysis is a surface phenomenon occurring at the oil-water interface of fat droplets. Though this process, triglycerides are hydrolysed to monoglycerides and fatty acids forms. Pancreatic lipase acts highly in the sn- 1 and sn- 3 positions in the triglyceride molecule, although the sn- 2 
position is also hydrolysed by this enzyme (Hunter, 2005). Furthermore, bile salts also take part in this process by removing the lipolytic products from the surface of the lipid globules, contributing to maintain the accessibility of lipases, and thus lipolysis (Maldonado-Valderrama et al., 2011). When a molecule of triglyceride is hydrolysed into monoglycerols and fatty acids, the action of the bile salts is also required, as they contribute to the formation of micelles that facilitate absorption, given the fact that lipolysis products are insoluble in the aqueous digestion medium. Once incorporated into the micelles, the lipolysis products can get in contact with the microvilli where absorption take place through the cell membrane by means of diffusion (Mu \& Høy, 2004). Once free fatty acids are inside of the epithelial cells, they are transported to the endoplasmic reticule where the most part of them are esterified. The most part of lipids are synthetised at the epithelial cell and then incorporated in the chylomicrons. Afterwards, chylomicrons are expulsed by exocytosis reaching the lymphatic system. The intestinal absorption of lipids is a very effective process, as more than $95 \%$ of dietary lipids are recovered at the duodenal stage and only a small part is excreted with faeces in healthy subjects.

\section{Factors affecting bioaccessibility and bioavailability of nutrients}

As explained in the previous section, digestion is a complex process in which multiple factors are involved to achieve nutrient hydrolysis and absorption. Bioaccessibility of nutrients is the released fraction during digestion, while the bioavailability is the portion of the bioaccessible fraction that is susceptible to be absorbed. There are two main groups of factors affecting nutrient bioaccessibility and bioavailability: dietary factors and host-related factors.

\section{Dietary factors}

There are several factors related to the diet that can modify or modulate nutrient digestion. These factors can be related to the properties of a food or to the dietary patterns. The food properties that can affect nutrient bioaccessibility and digestibility are the chemical composition (macro and micronutrients, dietary fibre and bioactive 
compounds) and the physical structure of the dietary matrix. On top of these factors, the food processing and preparation can further alter bioaccessibility and digestibility.

The chemical composition and the specification of some compounds impact on its accessibility but also in its availability. For example, dietary iron present in two different forms, the heme and non-heme iron. Both forms of iron present different ways of absorption. Heme iron is directly absorbed while the absorption of non-heme iron depends on some compounds co-ingested within the same meal, such as vitamin $\mathrm{C}$ or acetic acid, both molecules contributing to the conversion of non-heme iron into an absorbable molecule (Cousins, 1996; Halberg, 1981). So, depending of chemical form of the iron its absorption can be affected, being the absorption of non-heme iron less efficient. Another example is found in some vitamins and antioxidant compounds. For example, the bioaccessibility and bioavailability of carotenoids vary depending of their isomeric structure (Yeum \& Russell, 2002). Another subfactor affecting nutrient digestion is food processing and cooking. Foods are usually summited to different mechanical or biotechnological treatments (milling, fermentation, boiling, baking, etc.) prior ingestion and these treatments belong mainly to industrial processing and culinary preparations. Cooking generally implies the use of thermal processes such as boiling, baking or frying, and in some cases, these treatments decrease the nutrient accessibility, especially regarding thermolabile compounds. For example, baking induces a decrease of the biological value of some proteins because aminoacids such as lysine, arginine and methionine are destroyed at high temperatures. Frying, however, induces to increased carotenoid bioaccessibility in tomato, as this bioactive compound is lipo-soluble and thus the incorporation of a fat-rich substrate facilitates its stability in the system (Hwang et al., 2012).

On the other hand, meal-related factors can also modify some mechanisms or processes related to digestion and absorption of nutrients. A case related to the presence of some fibres and polysaccharides is their ability of increasing the viscosity of the intestinal digesta, which prevents from the proper mixing of the digestive fluids with the food bolus, reducing the efficacy of the enzymatic reactions and consequently, nutrient digestibility (Grundy \& Wilde, 2021). Some carbohydrates such as starch granules have 
shown to dispose onto the surface of lipid droplets, physically preventing from the accessibility of lipases (Lentle, 2008). In addition, some types of protein are known to displace bile salts from the surface of lipid droplets, by this mechanism modifying the action of lipases. In turn, the droplet diameter determines the surface of fat that is accessible to enzymes, thus the binding between the enzyme and the substrate, affecting the extent of the hydrolytic reaction (Maldonado-Valderrama et al., 2011). Apart from the described interactions, when different food matrices are co-digested, the interplay of the different macronutrients with each other increase the complexity of the interactions, leading to other patterns of nutrient bioaccessibility and digestibility.

\section{Host-related factors}

There are different host-related factors affecting nutrient bioaccessibility and bioavailability, which can be divided into two groups: systemic and intestinal factors. Systemic factors influencing nutrient absorption are sex, age, genotype, style of life or physiological state.

For example, in the elderly, nutrient absorption is reduced due to some alterations related to digestive fluids secretion and absorption (Brownie, 2006), being some micronutrients affected the most, especially vitamin $\mathrm{B}_{12}$, calcium, vitamin $\mathrm{D}$ and $\mathrm{B}_{6}$ (Rusell, 2000). Another example of a systematic factor related to the differences that the gastrointestinal tract presents during the infancy (Sreedharan \& Mehta, 2004). The life style also influences the absorption of some nutrients, and concretely, Krall \& DawsonHughes, (2009) studied that smoking led to decreased calcium absorption efficiency in adults. Genetics also define the absorption of some micronutrients as in the case of lactose. Lactase is the brush-border enzyme that hydrolyses lactose and its secretion depends on the genotype. According to Mattar, de Campos Mazo \& Carrilho, (2012), the gen producing lactase persistence that implies the production of lactase during adulthood vary with the different countries. For example, European adults presented the variant related with lactase persistence while people from some Asian regions present lower prevalence of this gen. Thus, explain the lactose intolerances occurring in adults from regions such as Japan or China. 
As previously mentioned, intestinal factors, both at luminal and mucosal levels, also affect bioaccessibility and absorption of nutrients in several cases. Luminal factors are related to the intestinal secretions whereas mucosal implies the permeability alteration at the intestinal membrane. Both systems can be altered due to the presence of diseases such as chronic pancreatitis, atrophic gastritis, hyperthyroidism, CF, cirrhosis, etc (Shani-Levi et al., 2017). The consequences vary depending of the disease, for example, atrophic gastritis causes a reduction on chlorohydric acid by the cells of the stomach and thus impact on the bacteria proliferation. Several micronutrients need to be solubilised by the acid secretion prior absorption such in case of iron, zinc and calcium (Skikne et al., 1981; Stumiolo et al., 1991; Russel 2001). Chronic pancreatitis and CF cause maldigestion of proteins, lipids and carbohydrates because both diseases affect decreasing enzymes secretion. In the context of intestinal digestion conditions occurring in CF, interactions between lipid-protein and lipid-starch have been reported, consisting of the tendency towards decreased lipolysis extents in food matrices with high protein or starch content along with low content of fat. In contrast, under healthy intestinal conditions, these interactions have not been identified. In addition, depending on the food matrix structure (Guo et al., 2017), maximum lipolysis extents can be achieved in some cases such as "oil-in water emulsion", while more complex structures like "lipid inclusion in cells or tissues" showed decreased extents. Of note, these observations were noticed in simulated CF intestinal digestion conditions, and not in the standard conditions, in which the food matrix structure showed to have a minor effect on lipolysis extent (Calvo-Lerma et al., 2018). 


\subsection{Gastrointestinal alterations in $\mathrm{CF}$ and their impact on digestibility and bioaccessibility of nutrients: MyCyFAPP Approach}

\section{In vitro digestion model for $\mathbf{C F}$}

CF disease leads to a serial of GI disorders among which, intestinal alterations arise of special relevance because of their impact of lipid foods digestion Calvo-Lerma et al. (2018). As previously mentioned, one of the main pillars of MyCyFAPP project was to in vitro assess the contribution of both food and host-related factors to lipid digestibility under $\mathrm{CF}$ disease. Therefore, a specific CF-pancreatic insufficiency in vitro digestion model was to be set up based on the main intestinal alterations given in individuals with $\mathrm{CF}$ and exocrine pancreatic insufficiency.

The first key alteration in CF and pancreatic insufficiency is the obstruction of the pancreatic duct, which causes reduced or null secretion of bicarbonate and pancreatin. When the gastric chyme passes through the pylorus and enters the duodenum, the acid $\mathrm{pH}$ is neutralized by the secretion of pancreatic juice containing bicarbonate. In the term of 30 minutes approximately, the $\mathrm{pH}$ increases up to 6.5 , reaching values around 7 at the end of the small intestine. The alkaline $\mathrm{pH}$ allows pancreatic lipase to exert its hydrolytic action satisfactorily, this part of the intestinal tract accounting for the largest extent of lipid breakdown and absorption (Minekus et al., 2014). However, in exocrine pancreatic insufficiency, the obstructed pancreatic duct prevents from pancreatic juice pouring into the duodenum (Borowitz et al., 2005). So that, the acidity of the digestion content remains for a longer time and is not until one hour that $\mathrm{pH}$ can hardly reach a value of 6 (Carrière et al., 2005). The consequences of this delay in alkalinisation imply that lipases are not activated, skipping a large part of the absorption tract with undigested lipids (Baker, 2013). The sub-optimal pH for lipase activity leads to mal-digestion and malabsorption of lipids, which are washed away with faeces, carrying along other lipidic molecules such as liposoluble vitamins (Baker, 2013). The pancreatic juice containing pancreatin, a mixture of proteases, amylases and lipase, is neither poured into the duodenum because of the same mechanism preventing bicarbonate secretion. This is 
critical in $\mathrm{CF}$, as pancreatic lipase is the main enzyme responsible for dietary lipid digestion in the digestion process (Carrière et al., 1993). When pancreatic insufficiency is present in $\mathrm{CF}$, the secretion of pancreatin is in most of the cases null. Thus, the risk for lipid mal-digestion and mal-absorption is not only persistent because of the suboptimal $\mathrm{pH}$ conditions, but for the lack of enzymes itself. As above explained, this disorder is palliated with pancreatic enzyme replacement therapy (PERT). PERT consists of the oral administration of porcine-origin, encapsulated granules of pancreatin in every meal. This supplement including lipase can be considered as the only source of this enzyme in CF and pancreatic insufficiency. Despite the therapy succeeds in supplying a source of lipase to the intestinal tract, its effectivity is conditioned by the low intestinal $\mathrm{pH}$ and in some cases, the reduced bile salts concentration, and the characteristics of the foods.

Another relevant alteration related to the physiology of digestion in CF and pancreatic insufficiency is the reduced concentration of bile salts in the intestinal digestion medium. The gallbladder is an organ attached to the liver that exerts its function in the digestion process by secreting bile salts. Bile salts are a crucial agent in emulsifying dietary lipids in the intestinal medium. Its micellation function is also necessary to lipids being absorbed by the epithelial cells. When this function is accomplished, bile salts are reabsorbed and recirculated back to the gallbladder. However, in CF the recirculation of bile salts is reduced, resulting in biliary juice with low bile salts concentration. Also, in the context of CF, the biliary duct can be obstructed, reducing the secretion of the biliary fluid. These situations have been reported to cause bile salts concentration in the digestion medium up to ten times lower $(1 \mathrm{mM})$ than in normal conditions, in which it is around $10 \mathrm{mM}$. The low presence of bile salts prevents from micellation, hindering lipases adsorption onto lipid molecules overall reducing lipolysis. However, the low bile salts concentration has shown to significantly reduce lipolysis in some foods, but in others the negative effect has not been evidenced (CalvoLerma et al., 2018). A possible explanation for this fact could be related to the amount and type of some dietary proteins, that when released to the digestion medium could play a similar emulsifying role than bile salts (Sarkar et al., 2010). 
Altogether, as later on explained in the experimental plan of the thesis, the in vitro digestion model for $\mathrm{CF}$ patients with pancreatic insufficiency that was set up to address the studies of fat digestion and the estimation of the optimal dose of enzymes in different foods, considered the described physiological alterations: usage of pancreatic enzyme supplements instead of pancreatin, incorporation of encapsulated pancreatin in the gastric stage (to simulate co-administration with food as occur- ring in PERT), lower bile salts concentration up to $1 \mathrm{mM}$ and lower intestinal $\mathrm{pH}(\mathrm{pH}$ 6). These amendments were supported by the clinical partners involved in MyCyFAPP and a thorough literature research in which the alterations occurring in this pathology were described: the obstruction of the pancreatic duct impedes the secretion of the pancreatic juice (lack of pancreatin) (Humbert et al., 2018) and bicarbonate (lower alkalinisation of the gastric content in the duodenum) (Robinson, Smith, \& Sly, 1990; Gelfond, Ma, Semler, \& Borowitz, 2013; Aburub, Fischer, Camilleri, Semler, \& Fadda, 2018), along with reduced bile salts secretion (Harries et al., 1979; Humbert et al., 2018).

\section{Dietary habits in patients with CF defining the focus food groups}

Screening lipid digestion in fat-containing foods, by simulating in vitro different intestinal conditions and doses of pancreatic enzyme supplements, could be an extremely broad topic. Therefore, in order to follow a practical approach, knowing dietary habits in the population with CF helped encompassing the target. A study assessing the dietary pattern of European children and adolescents with CF was used as the basis to find the fat-containing foods contributing the most to daily lipid intake (Calvo-Lerma et al., 2019b). This study showed that the focus should be placed on dairy products (milk, cheese, yoghurt and desserts), meat, fish, eggs, chocolate, pastries, bakery and nuts, as these were the major dietary sources contributing to lipid intake.

In the framework of MyCyFAPP project, and based on the results of the cited study, foods were classified into groups according to a common consensus criterion among the participants in the project. Table 1.1. gathers this classification, which is extracted from the public deliverable of the project, available at CORDIS, the European Commission's repository for research items: 
https://ec.europa.eu/research/participants/documents/downloadPublic?documentIds $=08$ 0166e 5a521fa43\&appId=PPGMS. It considered all the food products proceeding from EuroFIR ${ }^{\circledR}$ databases. Those food products with similar nutritional and functional characteristics were considered as the same type (group) and, more concretely, so were those food products with a similar role in the dietary pattern or similar technological processing (subgroups).

Table 1.1. Food groups classification according to MyCyFAPP Project, including those considered as representative of each, which were selected for studying fat digestion with the in vitro digestion model. Highlighted in bold the foods that were specifically studied in the framework of this doctoral thesis.

\begin{tabular}{|c|c|c|}
\hline Groups & Subgroups & Selected foods for in vitro digestion \\
\hline 1. Milk and dairy & $\begin{array}{l}\text { - Milk } \\
\text { - Yoghurt } \\
\text { - Cheese } \\
\text { - Milkshakes } \\
\text { - Cream }\end{array}$ & $\begin{array}{l}\text { - Whole cow's milk, whole goat's milk, semi- } \\
\text { skimmed cow's milk } \\
\text { - Natural yoghurt, sugar added yoghurt } \\
\text { - Mild cheese, aged cheese, fresh cow cheese and } \\
\text { fresh goat cheese. } \\
\text { - Chocolate milkshake } \\
\text { - Cream }\end{array}$ \\
\hline Groups & Subgroups & Selected foods for in vitro digestion \\
\hline 2. Meat and derivatives & $\begin{array}{l}\text { - Chicken meat } \\
\text { - Pork meat } \\
\text { - Beef meat } \\
\text { - Turkey meat }\end{array}$ & $\begin{array}{l}\text { - Chicken drumstick } \\
\text { - Pork loin } \\
\text { - Beef steak } \\
\text { - Turkey breast }\end{array}$ \\
\hline
\end{tabular}




\begin{tabular}{|c|c|c|}
\hline & $\begin{array}{l}\text { - Lamb meat } \\
\text { - Cold meats } \\
\text { - Minced meat } \\
\text { - Sausages and } \\
\text { burgers } \\
\text { - Others }\end{array}$ & $\begin{array}{l}\text { - Hamburger } \\
\text { - Sausage } \\
\text { - Luncheon ham } \\
\text { - Pate } \\
\text {-Cured ham } \\
\text {-Cooked ham }\end{array}$ \\
\hline 3. Fish and derivatives & $\begin{array}{l}\text { - Blue fish } \\
\text { - White fish } \\
\text { - Seafood } \\
\text { - Others }\end{array}$ & $\begin{array}{l}\text { - Salmon (fresh, marinated and cooked), canned } \\
\text { tuna } \\
\text { - Hake }\end{array}$ \\
\hline 4. Eggs & - All types of egg & -Chicken egg with different cooking methods \\
\hline 5. Fruit & - All types of fruit & - Avocado and olives \\
\hline 6. Vegetables & - All types of fruit & - Fried tomato \\
\hline 7. Beans and pulses & $\begin{array}{l}\text { - All types of } \\
\text { beans and pulses }\end{array}$ & \\
\hline Groups & Subgroups & Selected foods for in vitro digestion \\
\hline 8. Cereal and grains & $\begin{array}{l}\text { - Bread } \\
\text { - Pasta } \\
\text { - Rice } \\
\text { - Potato }\end{array}$ & $\begin{array}{l}\text { - White bread, brown bread } \\
\text { - French fries }\end{array}$ \\
\hline
\end{tabular}




\begin{tabular}{|c|c|c|}
\hline & $\begin{array}{l}\text { - Corn } \\
\text { - Pseudocereals } \\
\text { - Seeds } \\
\text { - Others }\end{array}$ & - Chia \\
\hline $\begin{array}{l}\text { 9. Sweets and savory } \\
\text { snacks }\end{array}$ & $\begin{array}{l}\text { - Chocolate } \\
\text { - Pastries and } \\
\text { cakes } \\
\text { - Salty bakery } \\
\text { - Breakfast cereal } \\
\text { - Biscuits } \\
\text { - Others }\end{array}$ & $\begin{array}{l}\text { - White, milk and dark chocolate } \\
\text { - Muffin, waffle, croissant } \\
\text {-Chocolate cookie and biscuit }\end{array}$ \\
\hline 10. Fats & $\begin{array}{l}\text { - Vegetal oils } \\
\text { - Margarine } \\
\text { - Butter }\end{array}$ & $\begin{array}{l}\text { - Olive oil } \\
\text { - Regular margarine } \\
\text { - Regular butter }\end{array}$ \\
\hline 11. Nuts & - All types of nuts & - Walnuts, peanuts \\
\hline
\end{tabular}

From a practical approach to the experimental tasks, the selected foods for in vitro digestion (52 in total) were divided into two categories: vegetal-origin and animalorigin. The first category was addressed in the frame of a previous doctoral thesis (PazYépez, 2019) while the second, conform the results of the present one. 


\section{Lipid digestibility of vegetal-origin food products}

As anticipated, the study of fat digestibility in vegetal-origin foods was previously addressed, and the presentation and discussion of the obtained results were dissertated in a doctoral thesis (Paz-Yépez, 2019). The aim of that Ph.D. work was analysing the influence of the inherent-to-food factors and the host-related factors on lipid digestibility and bioactive compounds bioaccessibility in food matrices with vegetal-origin fat. The ultimate goal was, as part of MyCyFAPP project, establishing an optimal dose of pancreatic enzyme supplements for the studied representative food products within the category of vegetal-origin.

The selected matrices in this context were: chia seeds and sprouts, walnuts and peanuts, white, milk and dark chocolate, and bakery products, including whole-grain bread, white bread, regular biscuits, chocolate-chips biscuits, chocolate cake, doughnut, waffle, croissant and muffin. All of them were subjected to the same in vitro digestion model described in the section above.

The results pointed at food matrix structure, composition, type of food processing and the interaction among nutrients are determinant in lipolysis and bioaccessibility of bioactive compounds when simulating the altered intestinal conditions occurring in the CF-PI model, whereas these effects were not so noticeable in the standard simulated conditions. More concretely, in the case of chia seeds and nuts, the disintegration extent of the matrix in the oral stage was the major determinant in macronutrient digestibility, while the composition of nutrients or the type of fat did not play a significant role (Paz-Yépez et al., 2019; Calvo-Lerma et al., 2020d). In the case of chocolate products, however, the physical structure among the matrices was similar and was not a determinant variable in the extent of lipolysis. In these matrices, the nutritional composition (amount and type of fat, protein, emulsifiers, bioactive compounds) showed to have a significant impact on fat digestion (Paz-Yépez et al., 2019). Finally, in the case of bakery products, both the physical structure of the food matrix and the composition in macronutrients were factors explaining the final lipolysis obtained. 
The experimental trials conducted at different doses of the enzyme supplement allowed for determining the dose that maximized lipolysis for the assessed food products, and thus led to the assignation of a recommended dose to the vegetal-origin foods. Therefore, these results contributed to the set-up of the scientifically validated method to adjust the dose of pancreatic enzyme supplements according to food characteristics.

The present doctoral thesis contributes further to the milestone of having an evidence-based method to adjust the dose of enzyme supplements by uncovering the effects of food matrix structure, intestinal digestion conditions and dose of pancreatic enzyme supplements in animal-origin and fat containing foods. 


\section{References}

Aburub, A., Fischer, M., Camilleri, M., Semler, J. R., \& Fadda, H. M. (2018).

Comparison of $\mathrm{pH}$ and motility of the small intestine of healthy subjects and patients with symptomatic constipation using the wireless motility capsule. International Journal of Pharmaceutics, 544, 158-164.

Amara, S., Bourlieu, C., Humbert, L., Rainteau, D., \& Carrière, F. (2019). Variations in gastrointestinal lipases, $\mathrm{pH}$ and bile acid levels with food intake, age and diseases: Possible impact on oral lipid-based drug delivery systems. Advanced drug delivery reviews, 142, 3-15.

Baker RD. Assessing exocrine pancreatic function: When the best test is not possible. Journal of Pediatric Gastroenterology Nutrition. 2013;56(2): 116-117.

Bender, A. (1992). Meat and meat products in human nutrition in developing countries (p. 91). Rome: FAO.

Boon, M., Calvo-Lerma, J., Claes, I., Havermans, T., Asseiceira, I., Bulfamante, A., ... \& Ribes-Koninckx, C. (2020). Use of a mobile application for selfmanagement of pancreatic enzyme replacement therapy is associated with improved gastro-intestinal related quality of life in children with cystic fibrosis. Journal of Cystic Fibrosis, 19(4), 562-568.

Borowitz, D., Durie, P. R., Clarke, L. L., Werlin, S. L., Taylor, C. J., Semler, J., ... \& Heubi, J. (2005). Gastrointestinal outcomes and confounders in cystic fibrosis. Journal of pediatric gastroenterology and nutrition, 41(3), 273-285.

Brayer GD, Luo Y, and Withers SG. The structure of human pancreatic alphaamylase at 1.8 A resolution and comparisons with related enzymes. Protein Sci 4: 1730-1742, 1995. PMID: 8528071.

Brownie, S. (2006). Why are elderly individuals at risk of nutritional deficiency?. International journal of nursing practice, 12(2), 110-118.

Brudevold, F., Kashket, S., \& Kent Jr, R. L. (1990). The effect of sucrose and fat in cookies on salivation and oral retention in humans. Journal of dental research, 69(6), 1278-1282. 
Calvo-Lerma, J., Fornés-Ferrer, V., Heredia, A., \& Andrés, A. (2018). In vitro digestion of lipids in real foods: influence of lipid organization within the food matrix and interactions with nonlipid components. Journal of food science, 83(10), 2629-2637.

Calvo-Lerma, J., Hulst, J., Boon, M., Martins, T., Ruperto, M., Colombo, C., ... \& Garriga, M. (2019). The relative contribution of food groups to macronutrient intake in children with cystic fibrosis: A European multicenter assessment. Journal of the Academy of Nutrition and Dietetics, 119(8), 1305-1319.

Calvo-Lerma, J., Martinez-Jimenez, C. P., Lázaro-Ramos, J. P., Andrés, A., Crespo-Escobar, P., Stav, E., ... \& Ribes-Koninckx, C. (2017a). Innovative approach for self-management and social welfare of children with cystic fibrosis in Europe: development, validation and implementation of an mHealth tool (MyCyFAPP). BMJ open, 7(3).

Calvo-Lerma, J., Hulst, J. M., Asseiceira, I., Claes, I., Garriga, M., Colombo, C., ... \& Ribes-Koninckx, C. (2017b). Nutritional status, nutrient intake and use of enzyme supplements in paediatric patients with Cystic Fibrosis; a European multicentre study with reference to current guidelines. Journal of Cystic Fibrosis, 16(4), 510-518.

Calvo Lerma, J. (2018). Study of fat digestion in foods as an innovative approach to adjust pancreatic enzyme replacement therapy in Cystic Fibrosis (Doctoral dissertation).

Calvo-Lerma, J., Hulst, J., Boon, M., Colombo, C., Masip, E., Ruperto, M., ... \& MyCyFAPP project. (2019a). Clinical validation of an evidence-based method to adjust Pancreatic Enzyme Replacement Therapy through a prospective interventional study in paediatric patients with Cystic Fibrosis. Plos one, 14(3), e0213216.

Calvo-Lerma, J., Fornés-Ferrer, V., Peinado, I., Heredia, A., Ribes-Koninckx, C., \& Andrés, A. (2019b). A first approach for an evidence-based in vitro digestion method to adjust pancreatic enzyme replacement therapy in cystic fibrosis. PloS one, 14(2), e0212459. 
Calvo-Lerma, J., Asensio-Grau, A., Heredia, A., \& Andrés, A. (2020a). Screening the impact of food co-digestion on lipolysis under sub-optimal intestinal conditions. $L W T, 118,108792$.

Calvo-Lerma, J., Asensio-Grau, A., Heredia, A., \& Andrés, A. (2020b). Lessons learnt from MyCyFAPP Project: Effect of cystic fibrosis factors and inherent-tofood properties on lipid digestion in foods. Food Research International, 133, 109198.

Calvo-Lerma, J., Roca, M., Boon, M., Colombo, C., de Koning, B., FornésFerrer, V., ... \& Ribes-Koninckx, C. (2020c). Association between faecal pH and fat absorption in children with cystic fibrosis on a controlled diet and enzyme supplements dose. Pediatric research, 1-6.

Calvo-Lerma, J., Paz-Yépez, C., Asensio-Grau, A., Heredia, A., \& Andrés, A. (2020d). Impact of Processing and Intestinal Conditions on in Vitro Digestion of Chia (Salvia hispanica) Seeds and Derivatives. Foods, 9(3), 290.

Calatayud, M., Xiong, C., Du Laing, G., Raber, G., Francesconi, K., \& Van de Wiele, T. (2018). Salivary and gut microbiomes play a significant role in in vitro oral bioaccessibility, biotransformation, and intestinal absorption of arsenic from food. Environmental science \& technology, 52(24), 14422-14435.

Campbell, J., Berry, J., \& Liang, Y. (2019). Anatomy and physiology of the small intestine. In Shackelford's Surgery of the Alimentary Tract, 2 Volume Set (pp. 817-841). Content Repository Only.

Carrière, F., Barrowman, J. A., Verger, R., \& René, L. (1993). Secretion and contribution to lipolysis of gastric and pancreatic lipases during a test meal in humans. Gastroenterology, 105(3), 876-888.

Carrière, F., Grandval, P., Renou, C., Palomba, A., Priéri, F., Giallo, J., ... \& Laugier, R. (2005). Quantitative study of digestive enzyme secretion and gastrointestinal lipolysis in chronic pancreatitis. Clinical Gastroenterology and Hepatology, 3(1), 28-38.

Colombo C, Littlewood J. (2011). The implementation of standards of care in Europe: state of the art. Journal of cystic fibrosis, 10 (2), S7-S15. 
Cousins, R. J., Zinc, I., Bowman, B. A., \& Russell, R. M. (1996). Present knowledge in nutrition. Present knowledge in nutrition.

Cummings, J.H. (1995) in Human Colonic Bacteria: Role in Nutrition, Physiology and Health, G.R. Gibson \& G.T. Macfarlane (Eds), CRC Press, Boca Raton, FL, pp 101-130

Di Costanzo, M., \& Canani, R. B. (2018). Lactose intolerance: common misunderstandings. Annals of Nutrition and Metabolism, 73(4), 30-37.

Domínguez-Muñoz, J. E. (2011). Chronic pancreatitis and persistent steatorrhea: what is the correct dose of enzymes? Clinical gastroenterology and hepatology, 9(7), 541-546.

Dona, A. C., Pages, G., Gilbert, R. G., \& Kuchel, P. W. (2010). Digestion of starch: In vivo and in vitro kinetic models used to characterise oligosaccharide or glucose release. Carbohydrate Polymers, 80(3), 599-617.

Gavião, M. B. D., Engelen, L., \& Van Der Bilt, A. (2004). Chewing behavior and salivary secretion. European Journal of Oral Sciences, 112(1), 19-24.

Gelfond D, Heltshe SL, Skalland M, Heubi JE, Kloster M, Leung D, et al. Pancre- atic enzyme replacement therapy use in infants with cystic fibrosis diagnosed by newborn screening. J Pediatr Gastroenterol Nutr 2018;66:657-63.

Guo, Q., Ye, A., Bellissimo, N., Singh, H., \& Rousseau, D. (2017). Modulating fat digestion through food structure design. Progress in Lipid Research, 68, 109118.

Grundy, M. M. L., \& Wilde, P. J. (2021). Plant Food Structure and Lipid Digestibility. In Bioaccessibility and Digestibility of Lipids from Food (pp. 113131). Springer, Cham.

Floch, J., Vilarinho, T., Zettl, A., Ibanez-Sanchez, G., Calvo-Lerma, J., Stav, E., ... \& Montón, J. L. B. (2020). Users' Experiences of a Mobile Health SelfManagement Approach for the Treatment of Cystic Fibrosis: Mixed Methods Study. JMIR mHealth and uHealth, 8(7), e15896. 
Fontijn-Tekamp, F. A., Van Der Bilt, A., Abbink, J. H., \& Bosman, F. (2004). Swallowing threshold and masticatory performance in dentate adults. Physiology \& behavior, 83(3), 431-436.

Hadley, G. (2012). The Gastrointestinal System at a Glance. Journal of Anatomy, 220(1), 116.

Hallberg, L. (1981). Bioavailability of dietary iron in man. Annual review of nutrition, 1(1), 123-147.

Heredia, A., Asensio-Grau, A., Calvo-Lerma, J., \& Andrés, A. (2021). Interactions Among Macronutrients and Their Effect on Lypolisis. In Bioaccessibility and Digestibility of Lipids from Food(pp. 151-168). Springer, Cham.

Hwang, E. S., Stacewicz-Sapuntzakis, M., \& Bowen, P. E. (2012). Effects of heat treatment on the carotenoid and tocopherol composition of tomato. Journal of food science, 77(10), C1109-C1114.

Jalabert-Malbos, M. L., Mishellany-Dutour, A., Woda, A., \& Peyron, M. A. (2007). Particle size distribution in the food bolus after mastication of natural foods. Food Quality and Preference, 18(5), 803-812.

Kalantzi, L., Goumas, K., Kalioras, V., Abrahamsson, B., Dressman, J. B., \& Reppas, C. (2006). Characterization of the human upper gastrointestinal contents under conditions simulating bioavailability/bioequivalence studies. Pharmaceutical research, 23(1), 165-176.

Krall, E. A., \& Dawson-Hughes, B. (1999). Smoking increases bone loss and decreases intestinal calcium absorption. Journal of Bone and Mineral Research, 14(2), 215-220.

Lentle RG, Janssen PWM (2008) Physical characteristics of digesta and their influence on flow and mixing in the mammalian intestine: a review. J Comp Physiol B 178(6):673-690

Li, C., Yu, W., Wu, P., \& Chen, X. D. (2020). Current in vitro digestion systems for understanding food digestion in human upper gastrointestinal tract. Trends in Food Science \& Technology, 96, 114-126. 
Maldonado-Valderrama, J., Wilde, P., Macierzanka, A., \& Mackie, A. (2011). The role of bile salts in digestion. Advances in colloid and interface science, 165(1), 36-46.

Mackie, A. (2019). The digestive tract: a complex system. In Interdisciplinary approaches to food digestion (pp. 11-27). Springer, Cham.

Macfarlane, G. T., \& Macfarlane, S. (2012). Bacteria, colonic fermentation, and gastrointestinal health. Journal of AOAC International, 95(1), 50-60.

Marciani, L., Faulks, R., Wickham, M. S., Bush, D., Pick, B., Wright, J., ... \& Spiller, R. C. (2008). Effect of intragastric acid stability of fat emulsions on gastric emptying, plasma lipid profile and postprandial satiety. British Journal of Nutrition, 101(6), 919-928.

Marciani, L., Manoj, P., Wright, J., Young, P., Moore, R. J., Smith, A., ... \& Spiller, R. C. (2000). MRI assessment of the grinding forces in the antrum. effects of solid food breakdown strength and meal viscosity on gastric emptying and satiety. Gastroenterology, 4(118), A142.

Minekus, M., Alminger, M., Alvito, P., Ballance, S., Bohn, T. O. R. S. T. E. N., Bourlieu, C., ... \& Dufour, C. (2014). A standardised static in vitro digestion method suitable for food-an international consensus. Food \& function, 5(6), 1113-1124

Mattar, R., de Campos Mazo, D. F., \& Carrilho, F. J. (2012). Lactose intolerance: diagnosis, genetic, and clinical factors. Clinical and experimental gastroenterology, 5, 113.

Neyraud, E., Palicki, O., Schwartz, C., Nicklaus, S., \& Feron, G. (2012). Variability of human saliva composition: possible relationships with fat perception and liking. Archives of oral biology, 57(5), 556-566.

Norton, J. E., Wallis, G. A., Spyropoulos, F., Lillford, P. J., \& Norton, I. T. (2014). Designing food structures for nutrition and health benefits. Annual Review of Food Science and Technology, 5, 177-195.

Paz-Yépez, C., Peinado, I., Heredia, A., \& Andrés, A. (2019). Influence of particle size and intestinal conditions on in vitro lipid and protein digestibility of 
walnuts and peanuts. Food Research International, 119(June 2018), 951-959. https://doi.org/10.1016/j.foodres.2018.11.014

Paz Yépez, C. A. (2019). Influencia de factores inherentes al alimento y al individuo sobre la digestibilidad de lipidos de origen vegetal (Doctoral dissertation).

Robinson, P. J., Smith, A. L., \& Sly, P. D. (1990). Duodenal pH in cystic fibrosis and its relationship to fat malabsorption. Digestive diseases and sciences, 35(10), 1299-1304.

Rowbotham, N. J., Smith, S., Leighton, P. A., Rayner, O. C., Gathercole, K., Elliott, Z. C., ... \& Chandran, S. (2018). The top 10 research priorities in cystic fibrosis developed by a partnership between people with CF and healthcare providers. Thorax, 73(4), 388-390.

Russell, R. M. (2000). The aging process as a modifier of metabolism. The American journal of clinical nutrition, 72(2), 529S-532S.

Russell, R. M. (2001). Factors in aging that effect the bioavailability of nutrients. The Journal of nutrition, 131(4), 1359S-1361S.

Salles, C., Chagnon, M. C., Feron, G., Guichard, E., Laboure, H., Morzel, M., et al. (2011). In-mouth mechanisms leading to flavor release and perception. Critical Reviews in Food Science and Nutrition, 51, 67-90.

Sams, L., Paume, J., Giallo, J., \& Carrière, F. (2016). Relevant pH and lipase for in vitro models of gastric digestion. Food \& function, 7(1), 30-45.

Sarkar, A., Horne, D. S., \& Singh, H. (2010). Interactions of milk proteinstabilized oil-in-water emulsions with bile salts in a simulated upper intestinal model. Food Hydrocolloids, 24(2-3), 142-151.

Shani-Levi, C., Alvito, P., Andrés, A., Assunção, R., Barberá, R., Blanquet-Diot, S., ... \& Lesmes, U. (2017). Extending in vitro digestion models to specific human populations: Perspectives, practical tools and bio-relevant information. Trends in Food Science \& Technology, 60, 52-63.

Sreedharan, R., \& Mehta, D. I. (2004). Gastrointestinal tract. Pediatrics, 113 (Supplement 3), 1044-1050. 
Skikne, B. S., Lynch, S. R., \& Cook, J. D. (1981). Role of gastric acid in food iron absorption. Gastroenterology, 81(6), 1068-1071

Stephenson, A. L., Mannik, L. A., Walsh, S., Brotherwood, M., Robert, R., Darling, P. B., ... \& Stanojevic, S. (2013). Longitudinal trends in nutritional status and the relation between lung function and BMI in cystic fibrosis: a populationbased cohort study. The American journal of clinical nutrition, 97(4), 872-877.

Sturniolo, G., Montino, M. C., Rossetto, L., Martin, A., D'inca, R., D'odorico, A., \& Naccarato, R. (1991). Inhibition of gastric acid secretion reduces zinc absorption in man. Journal of the American College of Nutrition, 10(4), 372-375.

Sreebny, L. M. (2000). Saliva in health and disease: an appraisal and update. International dental journal, 50(3), 140-161.

Stefanelli, G., Viscido, A., Longo, S., Magistroni, M., \& Latella, G. (2020). Persistent Iron Deficiency Anemia in Patients with Celiac Disease Despite a GlutenFree Diet. Nutrients, 12(8), 2176.

Troncoso, E., \& Aguilera, J. M. (2009). Food microstructure and digestion. Food Science \& Technology, 23(4), 24-27.

Van Der Bilt, A., Engelen, L., Abbink, J., \& Pereira, L. J. (2007). Effects of adding fluids to solid foods on muscle activity and number of chewing cycles. European Journal of Oral Sciences, 115(3), 198-205.

Watanabe, S., \& Dawes, C. (1988). A comparison of the effects of tasting and chewing foods on the flow rate of whole saliva in man. Archives of oral biology, 33(10), 761-764.

Woestenenk, J. W., van der Ent, C. K., \& Houwen, R. H. (2015). Pancreatic enzyme replacement therapy and coefficient of fat absorption in children and adolescents with cystic fibrosis. Journal of pediatric gastroenterology and nutrition, 61(3), 355-360.

Wolever, T. M., Tosh, S. M., Spruill, S. E., Jenkins, A. L., Ezatagha, A., Duss, R., ... \& Steinert, R. E. (2020). Increasing oat $\beta$-glucan viscosity in a breakfast meal slows gastric emptying and reduces glycemic and insulinemic responses but has no effect on appetite, food intake, or plasma ghrelin and PYY responses in healthy 
humans: A randomized, placebo-controlled, crossover trial. The American journal of clinical nutrition, 111(2), 319-328.

Yeum, K. J., \& Russell, R. M. (2002). Carotenoid bioavailability and bioconversion. Annual review of nutrition, 22(1), 483-504. 


\section{OBJECTIVES}

AND WORKING PLAN 


\section{OBJECTIVES AND WORKING PLAN}

\subsection{Objectives}

This doctoral thesis aims at gaining knowledge about the main food factors influencing lipolysis during in vitro digestion of animal-origin dietary sources (meat and meat products, cheese, egg and fish) in the context of CF. From a practical point of view, the obtained results would contribute to improve the pancreatic enzyme replacement therapy used in CF and pancreatic insufficiency.

In order to achieve this overall objective, the following specific objectives are posed (Figure 2.1):

1. To evaluate the effect of inherent-to-food factors (matrix structure, food composition and processing) on digestibility of animal-origin food matrices.

2. To elucidate the influence of host-related factors such as intestinal $\mathrm{pH}$, bile salts concentration and pancreatic enzymes dose on digestibility of animalorigin food matrices.

3. To address the impact of inherent-to-food and physiological factors on the bioaccessibility of relevant liposoluble bioactive compounds (carotenoids) present in the food products under study.

4. To analyse the possible correlations between the food related factors (food structure, composition and processing) and the lipolysis extent at different doses of pancreatic enzymes supplement.

5. To establish the optimal dose of pancreatic enzyme supplement that maximizes lipolysis during in vitro digestion of the studied foods. 

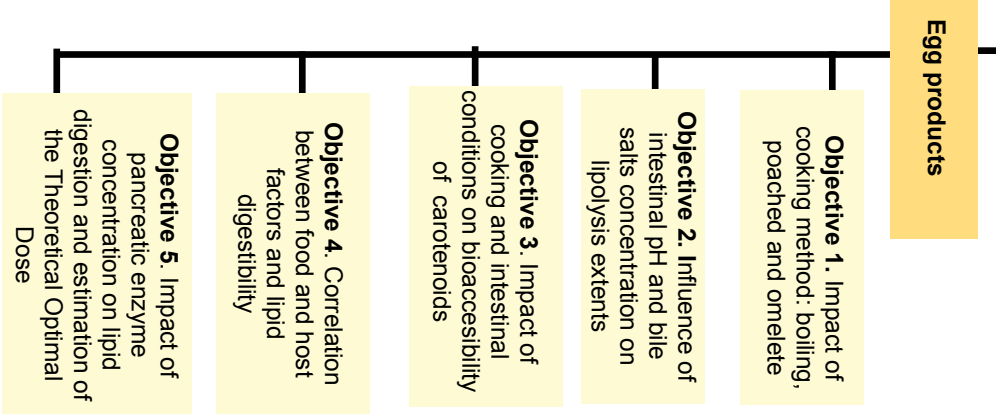

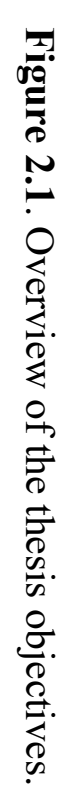
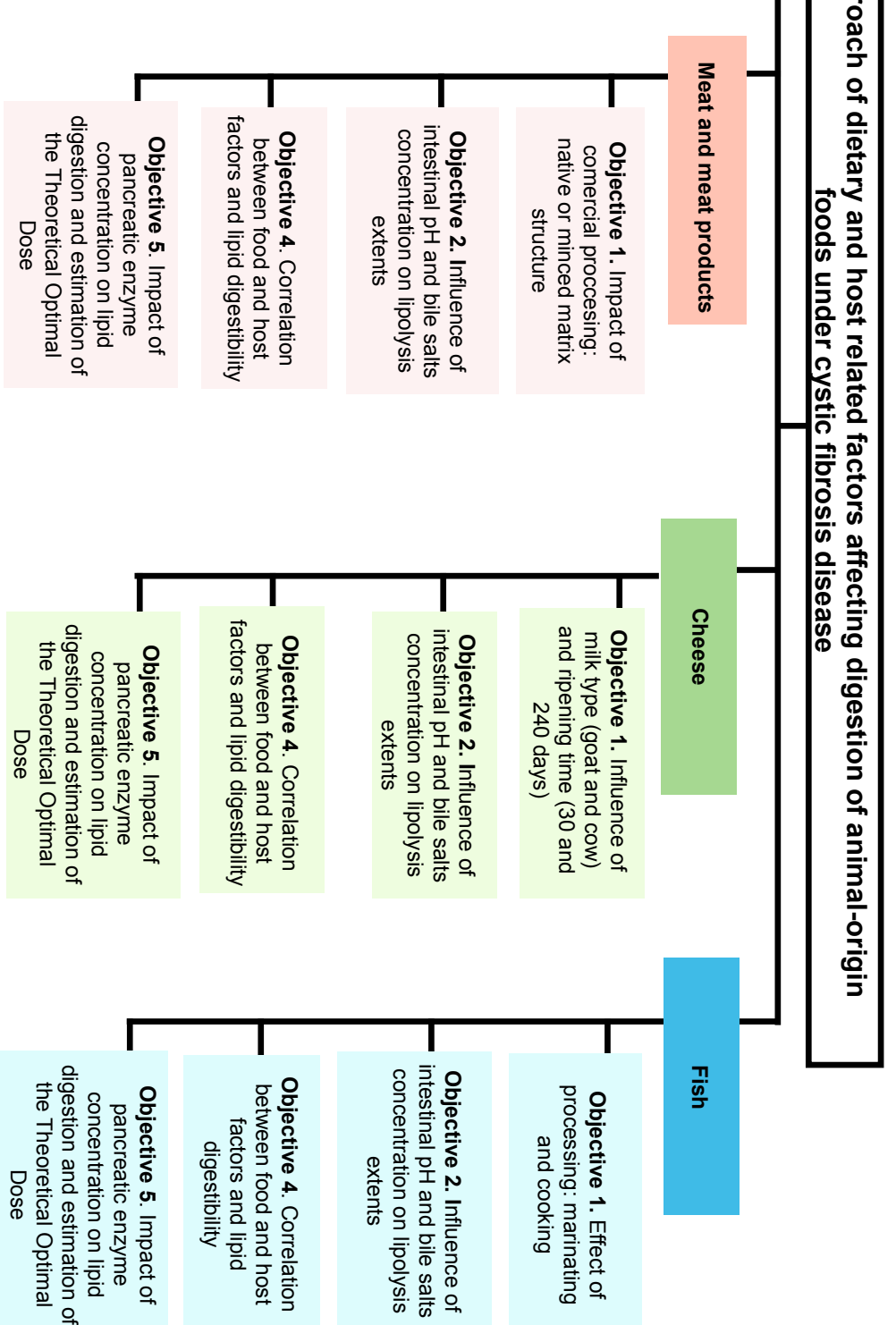


\subsection{Working plan}

The following tasks were conducted in order to reach the previously raised objectives:

1. Literature revision: setting the background of the state of the art for setting up some analytical methodologies and for the discussion of the results. Scientific literature related to gastrointestinal conditions of healthy and pancreatic insufficient subjects was used as a starting point for understanding the digestion events and defining the in vitro static model for the target population group.

2. Study of the effect of cooking and the impact of intestinal $\mathrm{pH}$, bile salts concentration and pancreatic enzyme concentration on digestibility and carotenoids bioaccessibility in egg products.

2.1 In vitro digestion assays under $\mathrm{CF}$ and standard intestinal conditions.

2.2 Analytical determination of lipolysis and proteolysis extents, matrix degradation index and carotenoids bioaccessibility.

3. Study of the effect of processing and the impact of intestinal $\mathrm{pH}$, bile salts concentration and pancreatic enzyme concentration on digestibility in meat and meat products.

3.1 In vitro digestion assays under $\mathrm{CF}$ and standard intestinal conditions.

3.2 Analytical determination of lipolysis extent and matrix degradation index.

4. Study of the effect of milk type and ripening, as well as the impact of the intestinal $\mathrm{pH}$, bile salts concentration and pancreatic enzyme concentration on digestibility in cheese.

4.1 In vitro digestion assays under $\mathrm{CF}$ and standard intestinal conditions.

4.2 Analytical determinations of lipolysis, proteolysis kinetics parameters and matrix degradation index, as well as fatty acid profile of cheese products. 
5. Analysis of the effect of household processing (marinating and microwavecooking) and the impact of intestinal $\mathrm{pH}$, bile salts concentration and pancreatic enzyme concentration on digestibility in fish, concretely salmon salar.

5.1 In vitro digestion assays under $\mathrm{CF}$ and standard intestinal conditions.

5.2 Analytical determination of lipolysis and proteolysis extent and matrix degradation index. 
3.MATERIALS AND METHODS 


\section{MATERIALS AND METHODS}

\subsection{Sample preparation and characterisation}

Four animal-origin food groups were selected to carry out the present thesis according to a dietary habits study in patients with CF. The food products studied in each group are presented as follows:

\section{Egg products}

Cooked egg, poached egg and omelette are the most frequent culinary preparations of chicken eggs, which in turn are the most frequently consumed. Therefore, eggs were subjected to three cooking methods to obtain diverse eggs matrices with different structural characteristics: boiled egg, poached egg and omelette. For boiling, whole shell eggs were placed in a cooking pan with boiling water covering the eggs during $10 \mathrm{~min}$ $\left(99 \pm 1^{\circ} \mathrm{C}\right)$ (Nimalaratne et al., 2012). After boiling, the whole eggs were placed under running tap water for $5 \mathrm{~min}$, and they were peeled right after. For poaching, eggs were broken into parafilm and then wrapped before scalding into a pan filled with boiling water for 4 minutes $\left(99 \pm 1^{\circ} \mathrm{C}\right)$. After that, the parafilm wraps were placed under running tap water for $5 \mathrm{~min}$. For omelette, eggs whites and yolks were mixed by stirring during 60 seconds and cooked in a household microwave oven (model GW72N, Samsung) for $80 \mathrm{~s}$ at $750 \mathrm{~W}, 2450 \mathrm{MHz})$.

\section{Meat and meat products}

Hamburger, chicken drumstick, pork loin, beef steak, luncheon ham, pate, cured ham, cooked ham and sausage were included in this group as they represented a wide range of the foods considered in this category, encompassing fresh and processed products. Hamburger (100\% minced pork meat), chicken drum, pork loin and beef steak were cooked in a household microwave oven (model GW72N, Samsung) for $4 \mathrm{~min}$ at $600 \mathrm{~W}, 2450 \mathrm{MHz}$. The rest of products (luncheon ham, pate, cured ham, cooked ham and sausage) were industrially processed and purchased ready to eat in the supermarket. 


\section{Cheeses}

Mild-cheese, aged cheese, fresh goat cheese and fresh cow cheese were representative of cheese with different ripening times and milk origins. All cheeses were processed by "Queserías Entrepinares" and the specifications of the processing techniques were the following: Mild-cheese (30 days of aging time) and aged-cheese (240 days of aging time) were two cheeses of different ripening conditions but with the same milk composition (55\% cow, $25 \%$ sheep and $20 \%$ goat). On the other hand, fresh goat cheese (100\% goat) and fresh cow cheese (100\% cow) had the same elaboration process but different milk origin.

Fish

Among fish varieties, salmon was selected because of its high fat content and since it is the major omega-3 dietary source. Cooked salmon, marinated salmon and raw salmon were studied in order to assess the effect of the preparation conditions. Salmon loins were separated in three sets from the same batch and frozen in order to preserve the same starting batch of salmon for all the subsequent determinations. One set was cooked using a microwave oven (Samsung GW72N) at 550W for 4 minutes. The second set was marinated according to Larrazábal-Fuentes et al., (2009). For this purpose, a mixture of salt and sugar in 1:1 (w/w) ratio was prepared. The loins were covered with the mixture and wrapped with parafilm during 9 hours in refrigeration $\left(5^{\circ} \mathrm{C}\right)$. Then, salmon was rinsed with water and dried with a paper towel to remove the excess water. The third set was not processed to assess digestibility in thawed raw salmon. 


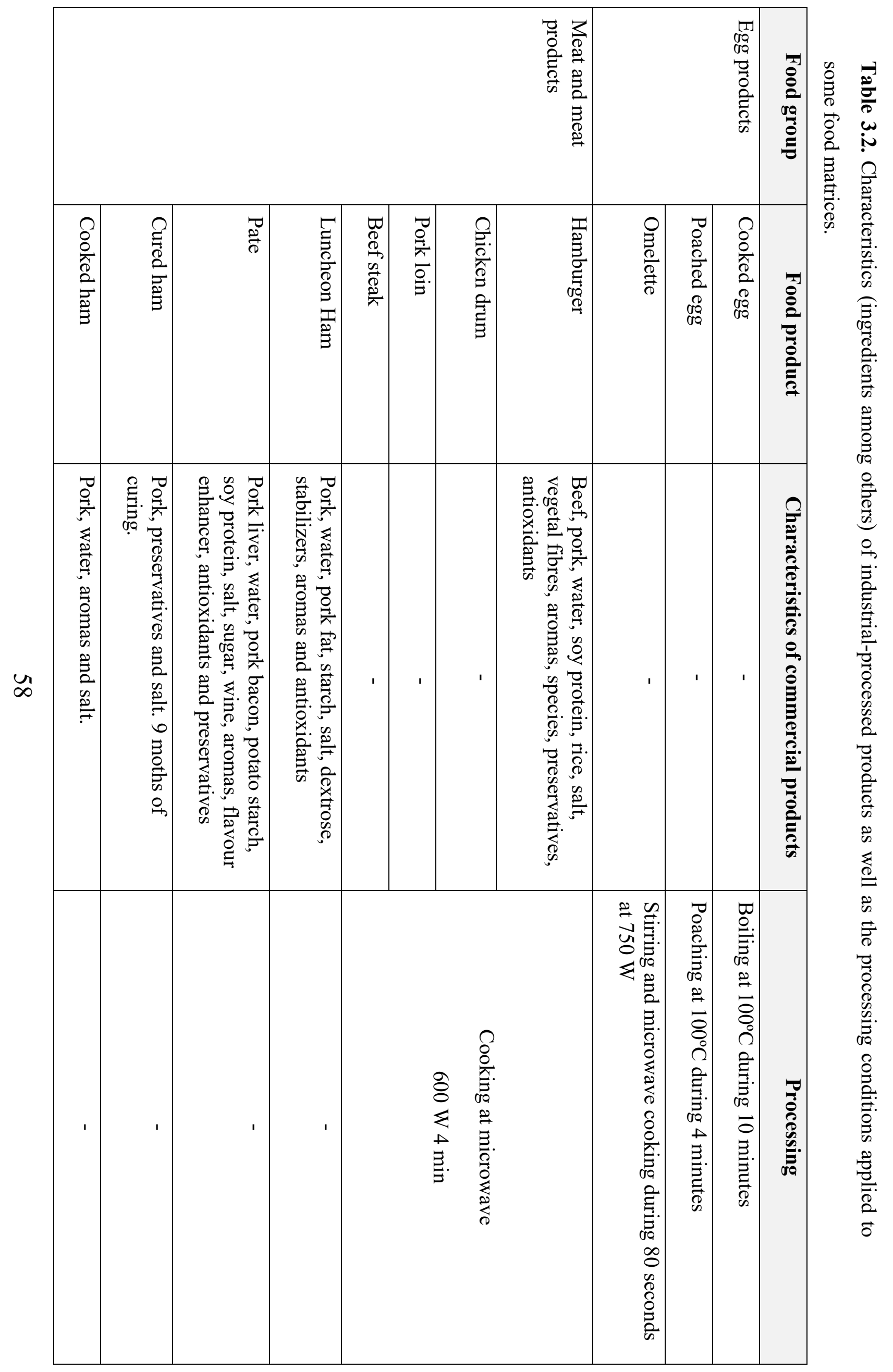




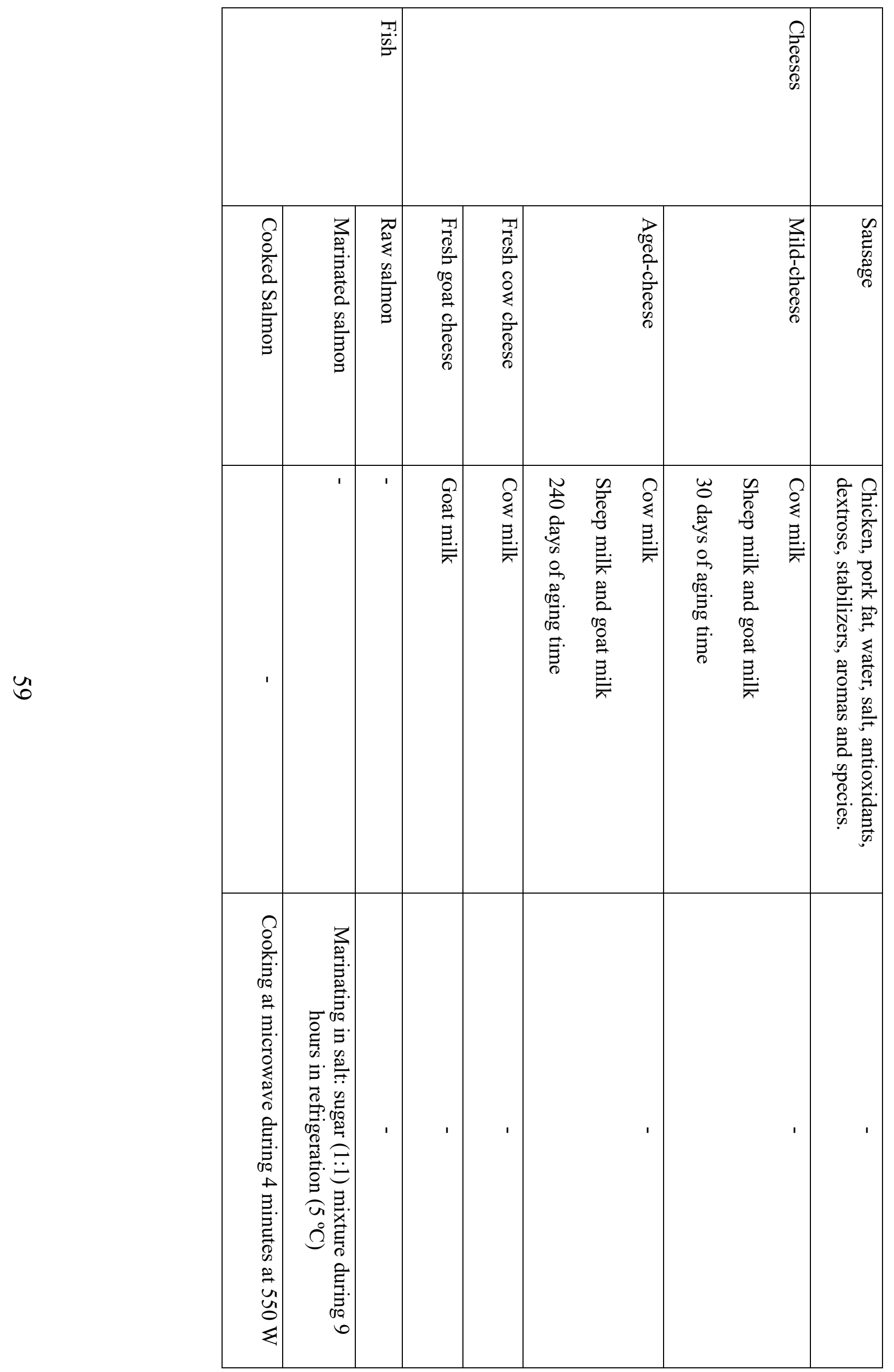


Compositional characterisation of food products

Fat, water and protein content were determined in all the food samples by following the official methods (AOAC, 2000). Water activity (aw) was only measured in salmon preparations by CX-2 AQUALab (Decagon Devices, Inc., Pullman, WA).

\subsection{Simulation of in vitro gastrointestinal digestion in CF}

The experimental design mainly consisted of two sets of experiments as shown Table 3.2. In the first set, different combination of intestinal $\mathrm{pH}$ and bile salts concentration were simulated to evaluate nutrient digestibility under a fixed pancreatin concentration (2000 UL/ g lipid). The intestinal condition of pH 7 and $10 \mathrm{mM}$ was selected such as the standard condition of a healthy adult. The other intestinal conditions refer to unfavourable intestinal conditions occurring in $\mathrm{CF}$ (pH 6 and bile salts concentration $1 \mathrm{mM}$ ) and exocrine pancreatic insufficiency ( $\mathrm{pH} 6$ and bile salts

concentration $10 \mathrm{mM}$ ). In the second set of experiments, different concentration of pancreatin was used to evaluate the influence of enzyme concentration on nutrient digestibility. 


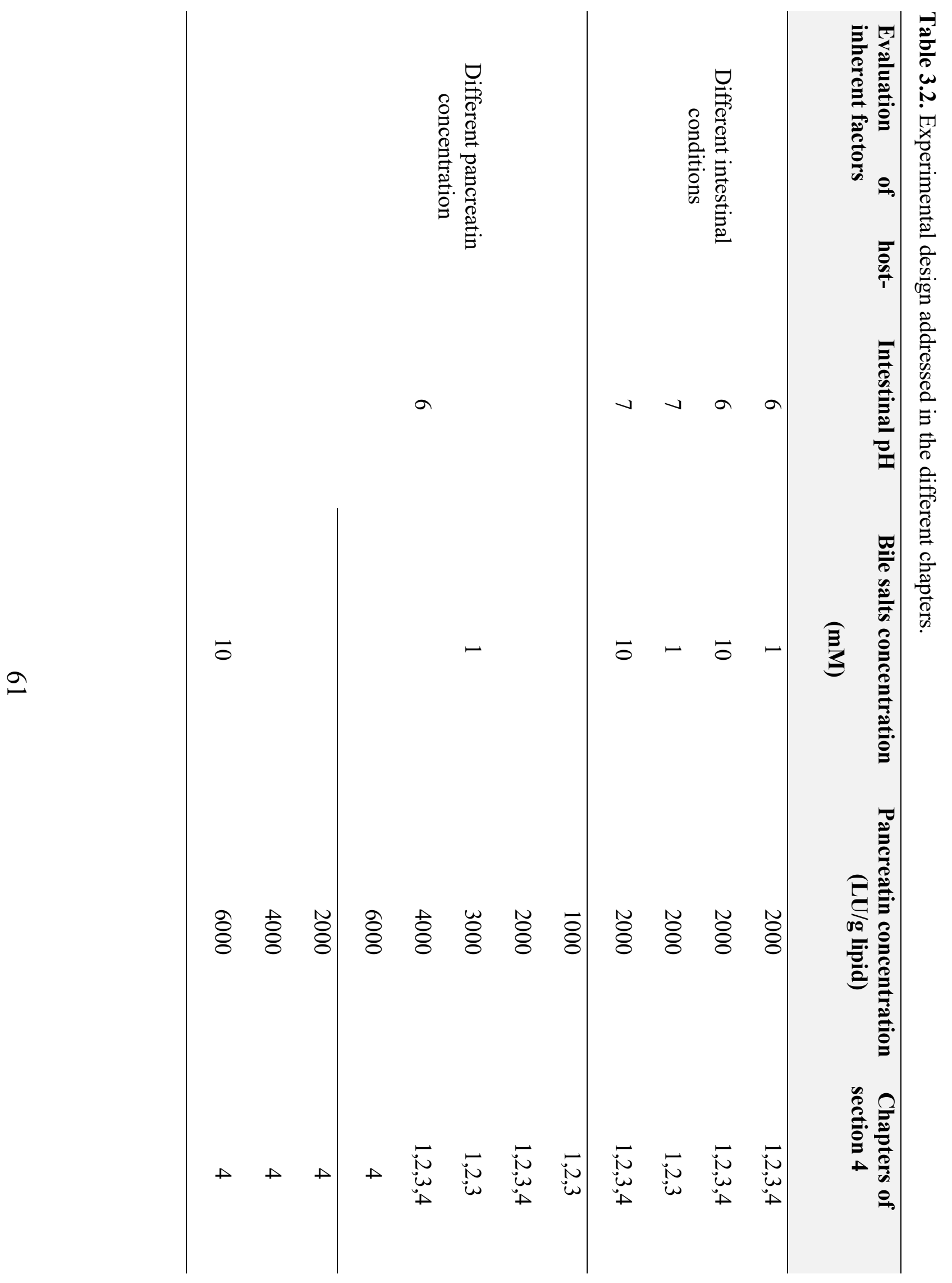


Digestion was simulated on the basis of the the standardized static in vitro digestion method for food published by Minekus et al., (2014) with some modifications to represent the intestinal conditions occurring in $\mathrm{CF}$ and pancreatic insufficiency (Table 3.3).

Table 3.3. Simulation parameters describing the CF-pancreatic insufficiency in vitro digestion model.

\begin{tabular}{|c|c|c|c|c|c|c|}
\hline $\begin{array}{c}\text { Digestion } \\
\text { stage }\end{array}$ & Duration & $\begin{array}{c}\text { Mechanical } \\
\text { force }\end{array}$ & $\begin{array}{l}\text { Digestion } \\
\text { fluid }\end{array}$ & pH & $\begin{array}{c}\text { Enzymatic } \\
\text { concentration }\end{array}$ & $\begin{array}{c}\text { Bile salts } \\
\text { concentration }\end{array}$ \\
\hline Oral & $5 \mathrm{~min}$ & Milling & $\begin{array}{l}\text { Simulated } \\
\text { salivary } \\
\text { fluid (5 } \\
\text { mL) }\end{array}$ & 7 & $\begin{array}{c}\text { Alfa-amylase } \\
45 \mathrm{U} / \mathrm{mL}\end{array}$ & - \\
\hline Gastric & $2 \mathrm{~h}$ & $\begin{array}{l}\text { Head-over } \\
\text { heels } \\
\text { agitation } \\
(55 \mathrm{rpm})\end{array}$ & $\begin{array}{l}\text { Simulated } \\
\text { gastric } \\
\text { fluid (10 } \\
\text { mL) }\end{array}$ & 3 & $\begin{array}{c}\text { Pepsin: } \\
2000 \text { U/mL }\end{array}$ & - \\
\hline Intestinal & $2 \mathrm{~h}$ & $\begin{array}{l}\text { Head-over } \\
\text { heels } \\
\text { agitation } \\
(55 \mathrm{rpm})\end{array}$ & $\begin{array}{l}\text { Simulated } \\
\text { intestinal } \\
\text { fluid } \\
(20 \mathrm{~mL})\end{array}$ & 6 & $\begin{array}{c}\text { Pancreatin: } \\
0 \mathrm{LU} / \mathrm{g} \text { fat } \\
1000 \mathrm{LU} / \mathrm{g} \text { fat } \\
2000 \mathrm{LU} / \mathrm{g} \text { fat } \\
3000 \mathrm{LU} / \mathrm{g} \text { fat } \\
4000 \mathrm{LU} / \mathrm{g} \text { fat }\end{array}$ & $\begin{array}{l}1 \mathrm{mM} \text { in the } \\
\text { intestinal } \\
\text { volume ( } 7.78 \\
\text { mg of bovine } \\
\text { extract / } \mathrm{mL})\end{array}$ \\
\hline
\end{tabular}


Table 3.4 illustrates the amounts and composition of the fluids required in each of the stages of the digestion process. The digestion fluids were prepared fresh daily from stock solutions, simulated salivary fluid (SSF), simulated gastric fluid (SGF) and simulated intestinal fluid (SIF) prepared according to Minekus et al., (2014). Each experimental condition was performed in triplicate. The in vitro digestion process was performed as follows:

Oral stage: Simulated salivary fluid (SSF; $\mathrm{pH} 8)$ at $37^{\circ} \mathrm{C}$, was added to the food samples in a ratio $1: 1(\mathrm{w} / \mathrm{v})$ and properly homogenized with a kitchen blender (Vario Mixer, Ufesa $600 \mathrm{~W}$ ) the time necessary until obtaining an equivalent consistency to tomato paste (Minekus et al., 2014).

Gastric stage: After the oral stage, simulated gastric fluid (SGF; pH 3) was added to each tube containing the oral bolus $(1: 1 \mathrm{v} / \mathrm{v})$. Pepsin was added into the SGF to reach a concentration in the gastric mixture of $(2000 \mathrm{U} / \mathrm{mL})$. The $\mathrm{pH}$ of the mixtures was adjusted with $\mathrm{HCl}(1 \mathrm{~N})$ to $\mathrm{pH} 2.8 \pm 0.1$ and samples were flipped from top to bottom at $55 \mathrm{rpm}$ for $2 \mathrm{~h}$ at $37^{\circ} \mathrm{C}$ using an Intell-Mixer RM-2 (Elmi Ltd, Riga, LV-1006, Latvia) and incubated in a chamber Selecta (JP Selecta SA, Barcelona). The pancreatin supplement was added in the gastric stage in order to simulate swallowing the pill in case of EPI situations.

Intestinal stage: Following the gastric stage, simulated intestinal fluid (SIF; $\mathrm{pH}$ 7) was added in a proportion $1: 1(\mathrm{v} / \mathrm{v})$ to each tube containing the gastric chime. The $\mathrm{pH}$ of the mixtures was adjusted to $\mathrm{pH} 6.0 \pm 0.1$ or $7.0 \pm 0.1$, depending on the conditions to be tested, with $\mathrm{NaOH}(1 \mathrm{~N})$. Samples were then being flipped from top to bottom at $55 \mathrm{rpm}$ for another $2 \mathrm{~h}$ at $37^{\circ} \mathrm{C}$. $\mathrm{pH}$ was monitored during the digestion process and readjusted if necessary to keep it constant (González-Bacerio, Rodríguez Hernández, \& del Monte Martínez, 2010). Then, tubes were placed in ice during 10 minutes in order to stop the enzymatic reactions. Digested sample collection was conducted according to the different analytical determinations. Only in case of salmon (chapter 4), lipolysis was determined by NMR at the whole digested. The remaining analytical determinations were determined in the bioaccessible fraction. Once intestinal digestion was finished, digested samples were centrifugate (4000 g-force, 20 minutes) and filtrate on a metallic 
sieve (1.6 $\mathrm{mm} \times 1.6 \mathrm{~mm}$ mesh) to separate the bioaccessible fraction from the solid ones. Each food matrix was digested in triplicate and then, analytical determinations were conducted at least in triplicate.

Table 3.4. Composition of simulated digestion fluids.

\begin{tabular}{lllll}
\hline \multicolumn{1}{c}{ Constituent } & \multicolumn{1}{c}{$\begin{array}{c}\text { SSF } \\
\mathbf{m m o l} / \mathbf{L}\end{array}$} & $\begin{array}{c}\text { SGF } \\
\mathbf{m m o l} / \mathbf{L}\end{array}$ & $\begin{array}{c}\text { SIF } \\
\mathbf{m m o l} / \mathbf{L}\end{array}$ \\
\hline $\mathrm{KCl}$ & 15.1 & 6.9 & 6.8 & 0.8 \\
$\mathrm{KH}_{2} \mathrm{PO}_{4}$ & 3.7 & 0.9 & 85 \\
$\mathrm{NaHCO}_{3}$ & 13.6 & 25 & 38.4 \\
$\mathrm{NaCl}$ & - & 47.2 & 0.33 \\
$\mathrm{MgCl}_{2}\left(\mathrm{H}_{2} \mathrm{O}\right)_{6}$ & 0.15 & 0.1 & - \\
$\left(\mathrm{NH}_{4}\right)_{2} \mathrm{CO}_{3}$ & 0.06 & 0.5 & 0.6 \\
$\mathrm{CaCl}_{2}$ & 1.5 & 0.15 & & \\
\hline
\end{tabular}

The addition of pepsin, $\mathrm{Ca}^{2+}$ solution and water will result in the correct electrolyte concentration in the final digestion mixture. SSF: Simulated Salival Fluid; SGF: Simulated Gastric Fluid; SIF: Simulated Intestinal Fluid.

\subsection{Analytical determinations}

\section{Analytical tools for lipolysis quantification}

There are different methodologies to study lipid hydrolysis in foods. Up to now, some methodologies have been commonly applied in the context of in vitro digestion simulations: free fatty acids enzymatic kit assay, $\mathrm{pH}$ stat method, nuclear magnetic resonance and chromatographic techniques. In the present doctoral thesis, free fatty acids enzymatic kit, nuclear magnetic resonance and chromatography techniques were applied to determine lipid hydrolysis. All analytical determinations were performed in triplicate at least.

Free fatty acids kit

Free fatty acid (FFA) released were estimated after in vitro digestion in all food matrices (chapter 1, 2, 3 and 4) using an enzymatic kit (Roche Diagnostics, Indianapolis, 
IN, USA) according to Lamothe et al., 2012. This method allows to measure the free fatty acids in digested samples easily and fast.

Aliquots from the liquid fraction of digested samples was diluted with a solution (5.6\% Triton X-100 and $6 \%$ ethanol in water) to solubilize FFAs ensuring lipase activity inactivation (Lamothe et al., 2012). Afterwards, FFAs were measured by means of an enzymatic kit (Roche Diagnostics, Indianapolis, IN, USA) using a spectrophotometer (UV/vis, Beckman Coulter). Palmitic (chapter 1, 2,3) and docosahexaenoic (chapter 4) acids were used such as standard for quantitative determination of FFAs. Lipolysis extent (\%) was expressed as the percentage of total fatty acids released after complete digestion, considering the release of two fatty acids per one molecule of triacylglycerol and the average molecular weight of triglyceride (chapter 1, 3 and 4) (Hunter, 2001). Lipolysis was also estimated as the fatty acids released per gram of initial lipid (chapter 2).

\section{Nuclear Magnetic Resonance}

${ }^{1} \mathrm{H}$ NMR is an accuracy technique that allows quantify and qualify the lipidic species (triglycerides, diglycerides, monoglycerides, fatty acids and glycerol). This analysis was only carried out in the salmon study (chapter 4). The procedure is detailed below:

\section{a) Lipid Extraction}

Undigested salmon was extracted with dichloromethane in a proportion $1: 2(\mathrm{w} / \mathrm{v})$ and placed in an ultrasonic bath for 1 hour. All the digestion fluids from salmon samples were extracted with dichloromethane in a proportion 2:3 (v/v). The extraction was performed twice to increase the extraction efficiency. Samples were centrifugated in falcon tubes at $6000 \mathrm{~g}$-force during $4 \mathrm{~min}\left(20^{\circ} \mathrm{C}\right)$. Then, a solution saturated of $\mathrm{NaCl}$ $(270 \mathrm{~g} / \mathrm{L})$ was added to separate the water fraction from lipid phase (dichloromethane). Samples were rota-evaporated to obtain the lipid fraction.

\section{b) NMR determination}

Then, $200 \mu \mathrm{l}$ of lipid samples was mixed with $400 \mu \mathrm{l}$ of deuterated chloroform containing $0.2 \%$ of non- deuterated chloroform and a small amount $[0.03 \%(\mathrm{v}: \mathrm{v})]$ of 
tetramethylsilane (TMS) which is used as internal reference. For the spectra acquisition, samples were introduced into a $5 \mathrm{~mm}$ dimeter tube and the ${ }^{1} \mathrm{H}$ NMR spectra of undigested and digested samples were recorded on a Bruker Avance 400 spectrometer operating at $400 \mathrm{MHz}$. Acquisition parameters: spectral width $6410 \mathrm{~Hz}$, relaxion delay $3 \mathrm{~s}$, number of scans 64, acquisition time 4.819 seconds and pulse width $90^{\circ}$.

\section{c) Spectra analysis}

The spectres were analysed by the Mestrenova software (V.14; Mnova campus licenses) and the values are provided as average and the standard deviation. The signal areas in the spectra are proportional to the number of protons that generate these signals. There are different ways of quantifying the lipolytic products generated during the lipolysis of triglycerides. Some authors take into account the acyl groups bound to different glyceryl backbone structures, while others consider all the glyceryl structures. So, the number of moles of each molecule can be calculated considering both acyl groups and glyceryl structures by the equations previously validated by Nieva-Echevarría (2014).

Gas Chromatography - Mass Spectrometry (GC-MS)

Fatty acid profile was analyzed in the chapter 3 according to Paz-Yépez et al., (2018) by GC-MS as follows:

a) Extraction of lipid phase:

Lipid fraction of different cheeses was separated by Soxlhet extraction according to the official methods (AOAC, 2000). In case of digested samples, after of intestinal digestion, the total content of the digestion tubes was centrifuged (4000 x g-force 20 minutes, $4{ }^{\circ} \mathrm{C}$ ) and then filtered on a metallic sieve $(1.6 \mathrm{~mm} \times 1.6 \mathrm{~mm}$ mesh) to separate liquid fraction and then, liquid fraction containing the hydrolysed fatty acids from lipolysis was freeze at $-40^{\circ} \mathrm{C}$ and then lyophilised. Both fat fraction of cheese and freezedried digested samples were submitted to a transesterification to methyl esters (FAMEs) with $\mathrm{BF}_{3}$ and methanol at $20^{\circ} \mathrm{C}$ according to the IUPAC standard method (IUPAC, 1992: Yaich et al., 2011). Lipid extraction was effectuated by adding $3 \mathrm{ml}$ of hexane in $15 \mathrm{ml}$ 
falcon tubes and by rotating head-over-heels at $55 \mathrm{rpm}$ during 90 minutes using IntellMixer RM-2 (Elmi Ltd, Riga, LV-1006, Latvia). Then, tubes were centrifuged for 5 minutes $125 \mathrm{~g}$-force and $1 \mathrm{~mL}$ of supernatant was dried with nitrogen flow and the residue was used for methylation. Then, $50 \mu \mathrm{L}$ of internal standard (pentadecanoic $1 \mathrm{mg}$ $/ \mathrm{mL}$ ), $40 \mu \mathrm{L}$ of hexane and $100 \mu \mathrm{L}$ of BF3 were added in the vial with the residue obtained, vortexed 15 seconds and heated at $70{ }^{\circ} \mathrm{C}$ during 90 minutes. Then $100 \mu \mathrm{L}$ of $\mathrm{NaCl}(25 \% \mathrm{w} / \mathrm{v}), 40 \mu \mathrm{L}$ of $\mathrm{H}_{2} \mathrm{SO}_{4}(10 \% \mathrm{w} / \mathrm{v})$ and $700 \mu \mathrm{L}$ of hexane were added and vortexed 15 seconds and settled for 30 minutes. After that time, $700 \mu \mathrm{L}$ of upper layer was taken and it was transferred to the injection vial ready to analyse.

b) Chromatography conditions and identification of fatty acids

Samples were analysed with an Agilent 5977A system and an HP - 5 MS UI (Agilent) ( $30 \mathrm{~m} \times 0.25 \mathrm{~mm}, 0.25 \mu \mathrm{m}$ film thickness) was used with helium. The oven temperature was programmed at $90{ }^{\circ} \mathrm{C}$ for $2 \mathrm{~min}$, increased to $222{ }^{\circ} \mathrm{C}$ at $5{ }^{\circ} \mathrm{C} / \mathrm{min}$ for 5 min, and increased to $280^{\circ} \mathrm{C}$ at $20^{\circ} \mathrm{C} / \mathrm{min}$ for $2 \mathrm{~min}$; split flow was adjusted at $1 \mathrm{~mL} / \mathrm{min}$, and injector temperature was at $280^{\circ} \mathrm{C}$. Mass spectra was recorded at $70 \mathrm{eV}$. Mass range was from $\mathrm{m} / \mathrm{z} 30$ to 650 . Identification of components was carried out by comparison of their matching against commercial libraries, built by genuine compounds and components, as well as mases literature date was also used for the identification. The software used for data acquisition and processing is $6890 \mathrm{GC}$ Chromatography Software for windows 8. Data analysis identification and quantification of fatty acid methyl ester (FAMEs) was accomplished by comparing the retention times of the peaks with those of pure standards (Supelco ${ }^{\circledR} 37$ Component FAMEs Mix, Sigma), and analysed under the same conditions.

\section{Determination of Matrix Degradation Index (MDI)}

MDI (\%) was estimated on the basis of the proportion of solids dispersed in the digested fluid at the end of the intestinal stage (Lamothe, Corbeil, Turgeon, \& Britten, 2012). The total content of the digestion tubes was centrifuged (4000 x g-force 20 minutes, $\left.4{ }^{\circ} \mathrm{C}\right)$ and then filtered on a metallic sieve (1.6 mm x $1.6 \mathrm{~mm}$ mesh) to separate the solid fraction. The liquid fraction was used for lipolysis and proteolysis extent 
determinations. To determine the mass of the solid large particles, the solid fraction of digesta was placed in a force air oven at $60{ }^{\circ} \mathrm{C}$ for 48 hours until reaching constant weight. MDI (\%) was expressed as grams of solid large particles in 100 grams of total solid fraction.

\section{Determination of proteolysis}

The extent of proteolysis was determined by characterizing the protein fraction soluble in acid trichloroacetic (TCA) according to Lamothe et al., (2014). Then, TCA was added to digested samples to a final concentration of $12 \%(\mathrm{w} / \mathrm{w})$. The mixture was vortexed, incubated for $15 \mathrm{~min}$ and filtered using a Whatman $\mathrm{n}^{\circ}$. 40 filter paper. The fraction soluble in $12 \%$ TCA consisted of small peptides and amino acid residues. The filtrate was diluted in a dissociating buffer (50 mM EDTA, $8 \mathrm{M}$ urea; $\mathrm{pH} 10)$. The extent of protein hydrolysis was estimated by measuring absorption at $280 \mathrm{~nm}$ against a blank prepared with the different digestion fluids. Results were reported as the percentage of the total protein concentration initially present in the sample using bovine serum albumin as standard protein (TCA soluble protein (\%)) (chapter 1 and 4).

In chapter 3, proteolysis in cheeses was determined at different times $(0,10,20$, 60, 90 and $120 \mathrm{~min}$ ) during gastric and intestinal stages, as explained above. Proteolysis was estimated by considering two parameters $\mathrm{OD}_{\max }$ and $\Delta \mathrm{OD} / \mathrm{h}$ initial from the mathematical model published by Bax, Aubry, Ferreira, Daudin, \& Gatellier, (2012) and using a Solver of Microsoft ${ }^{\circledR}$ Excel in order to estimate both parameters.

\section{Determination of xanthophylls content and bioaccessibility}

Initial lutein and zeaxanthin content in egg samples (chapter 1), raw and cooked, were characterized before and after digestion according to Nimarlantne et al., 2015; samples were homogenized, placed immediately at $-40{ }^{\circ} \mathrm{C}$ and kept at that temperature for at least $48 \mathrm{~h}$ before freeze drying $\left(48 \mathrm{~h},-45^{\circ} \mathrm{C}\right.$ and $1 \mathrm{mBar}$, Telstar, Terrasa, Spain). Freeze-dried samples were grounded to obtain a fine powder and they were stored at $20^{\circ} \mathrm{C}$ before the analysis of lutein and zeaxanthin content.

a) Extraction: 
Methanol, acetone, and hexane $[1: 1: 1(\mathrm{v} / \mathrm{v} / \mathrm{v})]$ were added to a glass tube containing $0.15 \mathrm{~g}$ of freeze-dried powder. After addition of the solvent mixture, tubes were shaken in a vortex for $30 \mathrm{~s}$ and immediately afterwards they continued to be flipped from top to bottom at $55 \mathrm{rpm}$ for $30 \mathrm{~min}$. Then, $2 \mathrm{~mL}$ of bidistilled water was added to each tube, and these were shaken for 1 min in the vortex mixer in order to separate the hydrosoluble and liposoluble phases adequately. Next, $1.5 \mathrm{~mL}$ of the non-polar phase containing the carotenoid pigments, were filtered with $0.22 \mathrm{~mm}$ nylon filters and transferred to amber HPLC glass vials. Hexane was then evaporated under nitrogen flow and xanthophylls were re-suspended in $400 \mu \mathrm{L}$ of hexane.

b) HPLC-DAD Analysis:

Xanthophylls (Lutein and Zeaxanthin) were separated using a separation module (Waters, 2695) comprising a pump and DAD detector (2996, Waters, USA), using methanol, tert-methyl-butyl-ether and water as mobile phase (v:v:v), solvent A (83:15:2) and solvent B (8:90:2). Gradient elution was carried out as follows: $90 \%$ A, 0-15 min; $90 \%$ to $5 \% \mathrm{~A}, 15-26 \mathrm{~min} ; 5 \%$ to $90 \%$ A (initial conditions), 26-28 min, at a flow rate of $1 \mathrm{~mL} / \mathrm{min}$, using a Develosil C30 Column $250 \mathrm{~mm} \times 4.6 \mathrm{~mm}$ i.d.5 $\mu \mathrm{m}$ (Phenomenex), and UV detection at $450 \mathrm{~nm}$. Each xanthophyll was quantified using a calibration curve of the pure standard (Sigma). To evaluate the changes undergone by the xanthophylls, results were expressed as \% of bioaccessibility, defined as the percentage of lutein and zeaxanthin that are solubilized in the digestion fluids after the intestinal stage. Thus, this index defines the proportion of xanthophylls (lutein or zeaxanthin) that could become available for absorption into the systematic circulation. Samples were prepared in triplicate.

c) Quantification of xanthophylls:

Six-point standard calibration curves were prepared for quantification purposes. External calibration plots were recorded with sample concentrations ranging from 0.05 to $30.00 \mu \mathrm{g} / \mathrm{mL}$. Concentrations were calculated using the corresponding all-E standard calibration curves. The limit of detection (LOD) and limit of quantitation (LOQ) were determined by injecting a series of diluted solutions with known concentrations. LOD 
and LOQ were defined as the signal-to-noise ratio equal to 3 and 10 respectively, according to the International Conference on Harmonization (ICH) Guideline (Dixon, 1999).

Bioaccessibility (\%) was calculated according to the Equation 1 (Martínez-Las Heras, Pinazo, Heredia, \& Andrés, 2017):

Bioaccessibility of xanthophylls $(\%)=\mathrm{A} / \mathrm{B} \cdot 100$

(Equation 1)

Where, A is either lutein or zeaxanthin content ( $\mu \mathrm{g} / \mathrm{g}$ product (boiled, poached or omelette egg)) quantified in the supernatant at the end of gastrointestinal digestion, and $\mathrm{B}$ is either lutein or zeaxanthin content in boiled, poached or omelette egg before digestion and expressed in the same units.

\section{Statistical analysis}

In order to study the significance of the differences of the food-related factors (processing) and the host-factors (intestinal $\mathrm{pH}$, bile salts concentration and pancreatin concentration) on lipid digestibility, unifactorial analysis of variance (ANOVA) was performed in the most of cases using Statgraphics Centurion XVII software with a confidence level of $95 \%$ (p-value $\leq 0.05$ ) (Chapters 1,3 and 4). Moreover, a multifactor analysis of variance (multi-variate ANOVA) was also performed with a confident interval of $99 \%(\mathrm{p}<0.001)$ and $95 \%(\mathrm{p}<0.05)$ to know which factor affected the response variables the most (F-ratio) (Chapter 1 and 4). The F-ratio value is directly proportional to the statistical effect of each factor on the response variables. The multifactor ANOVA was only applied to the results obtained at a fixed concentration of pancreatin concentration (2000 LU/g lipid). In chapter 2, analyses of linear regression models were performed by software $\mathrm{R}$ (version 3.4.2) using packages 225 betareg (version 3.1-0), lme4 (version 1.1-14) and NMF (version 0.20.6). A p-value lower than 0.05 was considered statistically significant. 


\section{Summary of the experimental methodology}

To close this section of the thesis, a brief and concise overview of the experimental methodology is summarised in Figure 3.1, which includes the target food matrices, the experimental design, the analytical determinations and the study outcomes.

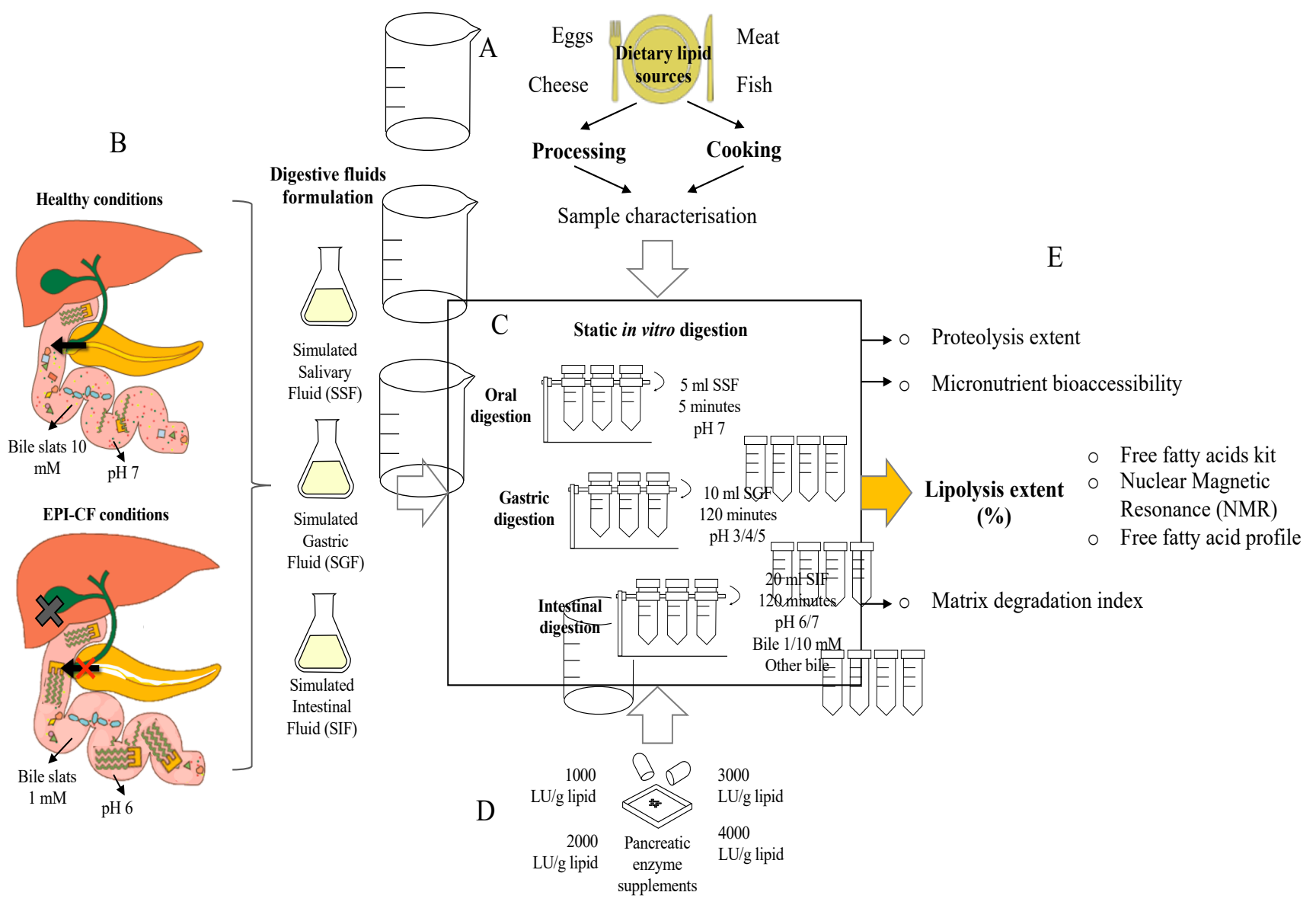

Figure 3.1. Overview of the experimental plan. Four animal origin food groups were processed prior in vitro digestion (A); two sets of gastrointestinal simulated conditions were established according to standard healthy and exocrine pancreatic insufficiency (EPI) and cystic fibrosis (CF) situations (B); an in vitro digestion model was set up and the specifications for the oral, gastric and intestinal stage were established (C); a range of lipase concentrations was studied in all the experimental plans; and after the simulation of the intestinal stage, proteolysis, micronutrient bioaccessibility, lipolysis and matrix degradation were determined (D). 


\section{References}

AOAC (2000). Official methods of analysis of AOAC International. (17th ed.). Gaithersberg, Maryland: Association of Official Chemists.

Bax, M., Aubry, L., Ferreira, C., Daudin, J., \& Gatellier, P. (2012). Cooking temperature is a key derminant of in vitro meat protein digestion rate: Investigation of underlying mechanisms. https://doi.org/10.1021/jf205280y.

Dixon, J. R. (1999). The international conference on harmonization good clinical practice guideline. Quality Assurance: Good Practice, Regulation, and Law, 6(2), 6574. https://doi.org/10.1080/105294199277860

Gelfond, D., Ma, C., Semler, J., \& Borowitz, D. (2013). Intestinal ph and gastrointestinal transit profiles in cystic fibrosis patients measured by wireless motility capsule. Digestive Diseases and Sciences, 58(8), 2275-2281. https://doi.org/10.1007/s10620-012-2209-1

González-Bacerio, J., Rodríguez Hernández, J., \& del Monte Martínez, A. (2010). Lipases: enzymes with potential for the development of immobilized biocatalysts by interfacial adsorption. Revista Colombiana de Biotecnología, 12(1), 113-140.

Humbert, L., Rainteau, D., Tuvignon, N., Wolf, C., Seksik, P., Laugier, R., \& Carrière, F. (2018). Postprandial bile acid levels in intestine and plasma reveal altered biliary circulation in chronic pancreatitis patients. Journal of Lipid Research, 59(11), 2202-2213.

Hunter, J. E. (2001). Studies on Effects of Dietary Fatty Acids as Related to Their Position on Triglycerides. Lipids, 36(7), 655-668

Larrazábal-Fuentes, M.J., Escriche-Roberto, I., \& Camacho-Vidal, M.D.M. (2009). Use of immersion and vacuum impregnation in marinated salmon (Salmosalar) production. Journal of Food Processing and Preservation, 33(5):635-650

Lamothe, S., Corbeil, M.-M., Turgeon, S. L., \& Britten, M. (2012). Influence of cheese matrix on lipid digestion in a simulated gastro-intestinal environment. Food \& Function, 3(7), 724. https://doi.org/10.1039/c2fo10256k 
Lamothe, S., Azimy, N., Bazinet, L., Couillard, C., \& Britten, M. (2014). Interaction of green tea polyphenols with dairy matrices in a simulated gastrointestinal environment. Food \& Function, 5(10), 2621-2631. https://doi.org/10.1039/c4fo00203b

Martínez-Las Heras, R., Pinazo, A., Heredia, A., \& Andrés, A. (2017). Evaluation studies of persimmon plant (Diospyros kaki) for physiological benefits and bioaccessibility of antioxidants by in vitro simulated gastrointestinal digestion. Food Chemistry, 214, 478-485. https://doi.org/10.1016/j.foodchem.2016.07.104

Minekus, M., Alminger, M., Alvito, P., Ballance, S., Bohn, T., Bourlieu, C., ... Brodkorb, A. (2014). A standardised static in vitro digestion method suitable for food an international consensus. Food \& Function, 5(5), 1113-1124. https://doi.org/10.1039/c3fo60702j

Nieva- Echevarría, B., Goicoechea, E., Manzanos, M. J., \& uill n, M. D. (2014). A method based on 1H NMR spectral data useful to evaluate the hydrolysis level in complex lipid mixtures. Food Research International, 66, 379-387.

Nimalaratne, C., Lopes-Lutz, D., Schieber, A., \& Wu, J. (2012). Effect of Domestic Cooking Methods on Egg Yolk Xanthophylls. Journal of Agricultural and Food Chemistry, 60(51), 12547-12552. https://doi.org/10.1021/jf303828n

Nimalaratne, C., Savard, P., Gauthier, S. F., Schieber, A., \& Wu, J. (2015). Bioaccessibility and Digestive Stability of Carotenoids in Cooked Eggs Studied Using a Dynamic in Vitro Gastrointestinal Model. Journal of Agricultural and Food Chemistry, 63(11), 2956-2962. https://doi.org/10.1021/jf505615w

Paz-Yépez, C., Peinado, I., Heredia, A., \& Andrés, A. (2018). Influence of particle size and intestinal conditions on in vitro lipid and protein digestibility of walnuts and peanuts. Food Research International, 119, 951-959. June 2018 https://doi.org/10.1016/j. foodres.2018.11.014.

Yaich, H., Garna, H., Besbes, S., Paquot, M., Blecker, C., \& Attia, H. (2011). Chemical composition and functional properties of Ulva lactucaUlva lactuca seaweed collected in Tunisia. Food Chemistry, 128(4), 895-901. https://doi.org/10.1016/j.foodchem. 2011.03.114. 


\section{RESULTS}




\section{CHAPTER 1}

\section{EFFECT OF COOKING AND INTESTINAL CONDITIONS ON LIPOLYSIS, PROTEOLYSIS AND XANTHOPHYLLS BIOACCESSIBILITY OF EGGS.}

The first chapter of the present doctoral thesis deals with the impact of different preparations on digestibility of the most relevant nutrients, including macronutrients (lipids and protein) and bioactive compounds (mainly xanthophylls) of egg: poached, hard-boiled and omelette. Furthermore, to address the goal of MyCyFApp project, their digestibility under different intestinal scenarios with different pancreatin concentration were also studied.

Egg is considered a highly nutritious food composed of two main parts with different composition and structure: the white, containing the protein, and the yolk, which gathers the lipids and liposoluble bioactive compounds. Lysozyme, ovomucoid, ovoinhibitor, and cysteine are proteins located in the albumen which present biological activity. On the other hand, egg yolk is the major source of bioavailable xhantophylls. Xhantophylls are a type of carotenoid with antioxidant activity and predominates in all the E-isomeric forms in the nature. The bioaccessibility and bioavailability of these compounds depend on lipid digestibility. First, xhantophylls (as well as the other nutrients) need to be released from the food matrix to be then bioaccessible for absorption. Bioaccessibility of nutrients depends on food-related factors such as food matrix structure, nutrient composition, processing and cooking. Eggs admits different types of cooking but culinary heat treatments are the most frequent household processes applied prior ingestion. These treatments imply denaturalisation of protein and relevant changes in the structural conformation of the food matrix, which present as a potential determinant of the degradation and the subsequent nutrient release, digestibility and bioaccessibility. After poaching and hard-boiling, both parts remain apart in the cooked resulting matrix; while in omelette the white and the yolk are homogenised by shaking, resulting in an emulsion-like structure system containing both protein and lipid. Regarding the aggregation state of food matrix resulting from thermal treatment, boiling 
leads to the solidification of both white and yolk due to the higher temperature achieved compared to poaching. In poaching, egg white becomes semi-solid while yolk, remains in its fluid native form. Finally, the solid structure resulting from omelette preparation consists of a continuous phase of denaturised protein in which lipid globules are dispersed. Therefore, the conformational differences of cooked eggs depending on the culinary preparations could have an impact on the fate of nutrients during digestion and can become more relevant in digestive disorders, as is the case of CF.

To address the study of these factors together with those related to altered intestinal alterations a static in vitro gastrointestinal digestion model was used. The analytical determinations performed after digestion included the matrix degradation index, lipolysis extent, proteolysis extent and xanthophyls' bioaccessibility. The matrix degradation was determined as the amount of solid digested after digestion. Proteolysis and lipolysis were measured in the bioaccessible fraction by following the same methodology as reported in the previous chapters: the trichloroacetic acid (TCA) soluble protein and the colorimetric kit. For xhantophylls determination, bioaccessible fraction was freeze-dried for the HPLC analysis.

The most relevant result of this study relates to lipolysis extents reached at the different intestinal simulated conditions, in the different egg matrices, and with different pancreatin concentrations, which all had an impact in this study outcome. Matrix degradation index is a parameter that represents the proportion of solids that are dispersed in digested fluid after intestinal digestion. The cooking method showed an impact on the matrix structure after cooking, and the effect both digestion and cooking in the final matrix was evaluated with matrix degradation parameter. Poached egg experimented a higher matrix degradation along digestion than hard-boiled egg or omelette. These results were related to the lipolysis extent achieved. First, with a pancreatin concentration of $2000 \mathrm{LU} / \mathrm{g}$ fat, and considering the healthy intestinal conditions, none of the matrices achieved $100 \%$ of lipolysis, being the hard egg showing the maximum extent $(87 \pm 12 \%)$, followed by poached egg ( $75 \%)$ and omelette achieving only $55 \%$. In the CF intestinal conditions, poached egg was the only matrix achieving an equivalent extent than in the healthy conditions (76\%). Besides, an increased lipolysis 
and proteolysis were found in all egg matrices as long as pancreatic concentration increases from 1000 to $2000 \mathrm{LU} / \mathrm{g}$ fat under the CF intestinal conditions. Complete lipolysis $(100 \%)$ and maximum proteolysis $(90 \%)$ was obtained after in vitro digestion of poached egg with 3000-4000 LU/g fat. In this context, all these findings support that the poached egg, having a liquid yolk where lipids are located, were more easily disintegrated and thus, lipids were more accessible to the lipases in pancreatin. In contrast, the hardest matrices (hard-boiled egg and omelette) showed more resistance against degradation during digestion and thus, against lipolysis. Regarding xhantophylls, both lutein and zeaxanthin were affected by the cooking method, being boiling the egg preparation leading to a highest bioaccessibility of both carotenoids. In contrast, in the CF intestinal conditions, omelette, cooking method results in a lower bioaccessibility of both carotenoids.

Moving onto the optimal dose of pancreatin enzyme supplement which maximise lipolysis, an enzyme concentration of $3000 \mathrm{LU} / \mathrm{g}$ fat was necessary for poached egg to achieve a value of $90 \%$ of lipolysis. In hard-boiled egg a maximum concentration of enzyme supplement, $4000 \mathrm{LU} / \mathrm{g}$ fat, was necessary to maximise lipolysis $(66 \%)$ while for omelette the maximum lipolysis (44\%) was achieved using an enzyme concentration of $2000 \mathrm{LU} / \mathrm{g}$ fat.

In this sense, the practical recommendation resulting from this study is that individuals with those altered intestinal conditions inherent to $\mathrm{CF}$ and pancreatic insufficiency should preferably consume eggs in the poached form, at the dose of 3000 $\mathrm{LU} / \mathrm{g}$ fat. 


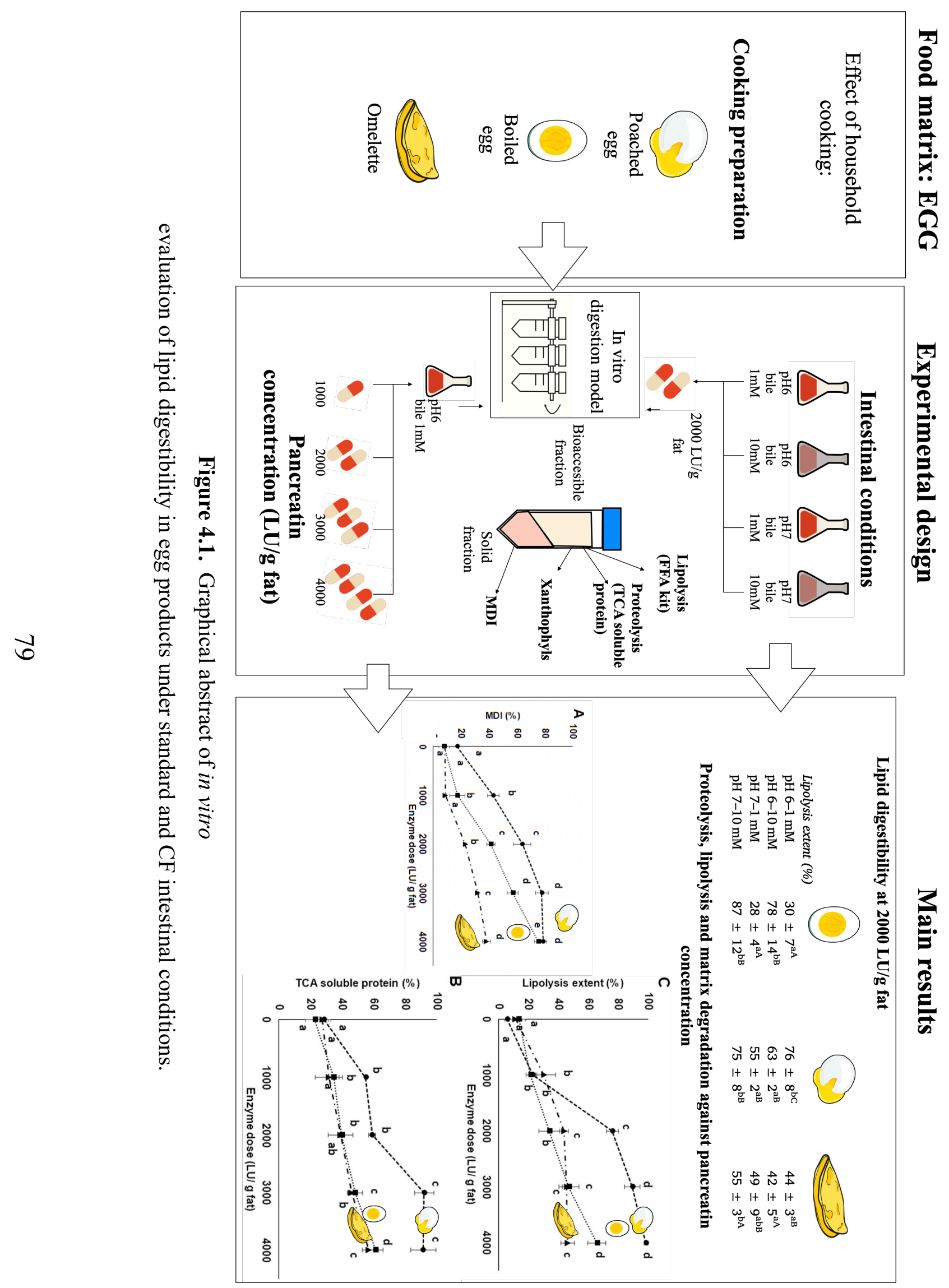


Title: Effect of cooking methods and intestinal conditions on lipolysis, proteolysis and xanthophylls bioaccessibility of eggs

\author{
Andrea Asensio-Grau, Irene Peinado, Ana Heredia and Ana Andrés \\ Journal of Functional Foods, 46, 579-586.
}

https://doi.org/10.1016/j.jff.2018.05.025

\begin{abstract}
Digestibility of macro and micronutrients depends on the ingested food as well as on gastrointestinal conditions, being those suboptimal in exocrine pancreatic insufficiency (EPI) patients. Under this scenario, oral enzyme supplementation improves enzymatic hydrolysis of nutrients. In this study, a static in vitro model was used to assess lipids and protein digestibility as well as lutein and zeaxanthin bioaccessibility of eggs cooked differently and submitted to different intestinal conditions. Boiled, poached and omelette eggs were digested under different intestinal conditions of $\mathrm{pH}$ ( 6 or 7), bile concentration (1 or $10 \mathrm{mM}$ ) and doses of the enzyme supplement (1000-4000 LU/g fat). Results showed that poaching resulted in higher digestibility of lipids and proteins, compared to boiling or omelette preparations, under gastrointestinal conditions of EPI ( $\mathrm{pH} \mathrm{6}$, bile $1 \mathrm{mM})$. Concerning xanthophylls bioaccessibility, boiling and poaching led to higher bioaccessibility of lutein and zeaxanthin than omelette under EPI conditions.
\end{abstract}

Keywords: Pancreatic insufficiency, Egg, Cooking, Lipolysis, Proteolysis, Xanthophylls 


\section{INTRODUCTION}

Egg has lately gained attention as a food to be considered into a healthy diet mainly due to its high protein content together with egg yolks antioxidant composition. Concretely, egg white contains around $10 \%$ of high-quality protein with a Protein Digestibility Corrected Amino Acid Score (PDCAAS) value of 1 . It includes albumins, mucoproteins and globulins, being ovalbumin (OVA) the main protein of egg white which represents $54 \%$ of egg white protein (Sponton, Perez, Carrara, \& Santiago, 2015; Weijers, Sagis, Veerman, Sperber, \& van der Linden, 2002). Egg yolk, on the other hand, is considered among many food types, one of the most important sources of xanthophylls with higher bioavailability than other common sources such as dark-green leafy vegetables (Nimalaratne, Lopes-Lutz, Schieber, \& Wu, 2012; Nimalaratne \& Wu, 2015; Seuss-baum, 2007; Sunwoo \& Gujral, 2015). Xanthophylls, the yellow pigments of egg yolk, are oxygenated carotenoids which allE-isomeric form predominates in nature. However, processing conditions such as stirring, heating, light, and oxygen exposure may lead to some different changes in protein and lipid digestibility, which may result in changes of the functionality and bioavailability of egg nutrients (Dugave \& Demange, 2003; Nimalaratne et al., 2012; Schieber \& Carle, 2005). Although the main xanthophylls present in egg yolk are lutein and zeaxanthin, other bioactive compounds such as vitamin $\mathrm{E}$ and omega-6/3 polyunsaturated fatty acids are also present (Sunwoo \& Gujral, 2015). Due to the lipophilic nature of these compounds, their absorption is closely related to the digestion of lipids. Thus, egg yolk can be an ideal food matrix to deliver highly bioavailable xanthophylls; indeed, bioavailability of lutein from lutein-enriched egg yolk was found to be greater than from lutein supplements or spinach (Chung, Rasmussen, \& Johnson, 2004; Handelman, Nightingale, Lichtenstein, Schaefer, \& Blumberg, 1999; Nimalaratne, Savard, Gauthier, Schieber, \& Wu, 2015).

In order to be bioavailable, lipophilic compounds will have to be released from their food matrix and micellarized, becoming then absorbable (bioaccessible), which means they can be absorbed by intestinal cells and be metabolized (Faulks \& Southon, 2005; Nimalaratne et al., 2015). Bioaccessibility of nutrients will depend on different 
factors related to the food itself such as food matrix, its composition, type of nutrients, processing and cooking methods (Granado-Lorencio et al., 2007; Nimalaratne et al., 2015; Pineda-Vadillo et al., 2017; Ryan, O'Connell, O’Sullivan, Aherne, \& O'Brien, 2008). Thus, analyzing the extent to which food matrix and processing can modify the stability, and the bioaccessibility of bioactive compounds is an essential first step for better understanding the actual biological activity of food constituents (RodríguezRoque et al., 2015). Furthermore, absorption of this lipophilic bioactive compounds will also depend on individual factors such as gastrointestinal conditions $\mathrm{pH}$, secretion and composition of the digestive fluids, transit time...) (Ryan et al., 2008; Whitcomb et al., 2010). All this might modify the extent of digestion and micellarization in the small intestine, and therefore, to absorb liposoluble compounds (Panozzo et al., 2013; PinedaVadillo et al., 2017).

Gastrointestinal environment will vary within different individuals depending on their age, gender, diet, etc. (Shani-Levi et al., 2017); these differences however, can become even more relevant under specific digestive disorders. It is the case of Exocrine Pancreatic Insufficiency (EPI), which is a disorder associated to several diseases such as pancreatic cancer, chronic pancreatitis $(\mathrm{CP})$ or cystic fibrosis (CF). The obstruction of the pancreatic duct in EPI, produces an insufficient secretion of sodium bicarbonate and pancreatic juice, containing digestive enzymes. Besides this lack of digestive enzymes, the decrease of pancreatic juice may also decrease the intestinal $\mathrm{pH}$, leading to nutrients mal-digestion and mal-absorption (Layer \& Keller, 2003; Naikwade, Meshram, \& Bajaj, 2009; Whitcomb et al., 2010). Due to pancreatic lipase is the main responsible of lipolysis (Carrière et al., 2000; Sikkens, Cahen, Kuipers, \& Bruno, 2010), this scenario compromises lipids' hydrolysis and absorption, leading therefore to a deficit in fatsoluble vitamins (A, D, E and $\mathrm{K}$ ) as well as other bioactive compounds, causing malnutrition. The current treatment for EPI involves oral administration of an enzymatic supplement in order to improve nutrients digestion and absorption (Armand, Fieker, \& Philpott, 2011). Nowadays, the current guidelines for EPI recommend an enzyme dose of 2000-4000 Lipase Units (LU)/g fat intake, being the only available parameters to guide health professionals on adjusting the prescribed doses, based on the overall fat 
content of the meals or on patients body weight (Turck et al., 2016). However, the optimal doses are still uncertain since satisfactory levels of fat absorption are not often achieved as they depend on food factors as well as on gastrointestinal (GI) conditions. Since human studies might give very precise information on the bioaccessibility of nutrients, due to its high cost, technical difficulty and ethical reasons, alternative methods are generally used. In vitro digestion methodologies represent therefore, a good approach to mimic in vivo luminal digestion and to assess the bioaccessibility of bioactive compounds (Faulks \& Southon, 2005; Hur, Lim, Decker, \& McClements, 2011; Minekus et al., 2014; Pineda-Vadillo et al., 2017).

To the authors knowledge, there are already some studies focusing on lipids absorption and antioxidants bioaccessibility using egg or egg based food matrices (Chung et al., 2004; Handelman et al., 1999; Nimalaratne et al., 2015; Pineda-Vadillo et al., 2017). However, in all of them, gastrointestinal conditions were simulated according to a standard healthy adult. Therefore, the aim of the present study was to in vitro evaluate the influence of some intestinal factors associated to EPI (intestinal $\mathrm{pH}$, bile concentration and the amount of enzyme supplement), as well as the effect of cooking procedure on lipids digestibility and xanthophylls bioaccessibility in eggs.

\section{MATERIALS AND METHODS}

\subsection{Materials}

Pancreatic enzymes supplements (Kreon 10,000 lipase units (LU)) were used to simulate in vitro digestion of an individual with EPI. Each capsule contains $150 \mathrm{mg}$ of gastro-resistant microspheres containing porcine pancreatic enzyme equivalent to 10,000 lipase U., 8,000 amylase U., and 600 protease U. The specific lipase activity of the Kreon was usually measured before the experiments (Carrière et al., 2000) and the amount of supplement added to the gastric stage was adjusted always to have the corresponding $\mathrm{LU} / \mathrm{g}$ fat according to the experimental design.

For the preparation of the simulated digestive fluids (Table 4.1.), the following chemicals were needed: pepsin from porcine gastric mucosa ( $\geq 2500 \mathrm{U} / \mathrm{g}$ protein), bovine bile extract, $\mathrm{KCl}, \mathrm{KH}_{2} \mathrm{PO}_{4}, \mathrm{NaHCO}_{3}, \mathrm{NaCl}, \mathrm{MgCl}_{2}(\mathrm{H} 2 \mathrm{O})_{6},\left(\mathrm{NH}_{4}\right)_{2} \mathrm{CO}_{3}$ and 
$\mathrm{CaCl}_{2}$ all of them from Sigma-Aldrich Chemical Company (St Louis, MO, USA). $\mathrm{NaOH}$ $(1 \mathrm{~N})$ and $\mathrm{HCl}(1 \mathrm{~N})$, were acquired from AppliChem Panreac. For the analytical determinations, Triton-X $100 \%$, petroleum ether, trichloroacetic acid (TCA), hexane, methanol, acetone, bovine serum albumin (BSA), methyl tert-butyl ether (MTBE), crystalline urea as well as the analytical standards of palmitic acid, lutein and zeaxanthin were all acquired from Sigma-Aldrich.

\subsection{Sample preparation}

Eggs were purchased from a local supermarket and divided into four equal sets before their use for the experiments that were performed at least 2 weeks prior to the expiry date. One set was used to characterize the raw product and the other three sets were used to analyse the influence of different cooking ways (boiled, poached and omelette). For the boiling, whole shell eggs were placed in a cooking pan, with boiling water covering the eggs, and they were boiled for $10 \min \left(99 \pm 1^{\circ} \mathrm{C}\right)$ (Nimalaratne et al., 2012). After boiling, the whole eggs were placed under running tap water for $5 \mathrm{~min}$, and they were peeled right after. For poaching, eggs were broken into parafilm and then wrapped before boiling them into a pan filled with boiling water for 4 minutes $\left(99 \pm 1^{\circ}\right.$ C). After that, the parafilm wraps were placed under running tap water for $5 \mathrm{~min}$. For omelette, eggs whites and yolks were mixed by stirring for 60 seconds, placed in a microwavable plate and cooked in a household microwave oven (model GW72N, Samsung) for $80 \mathrm{~s}$ at $750 \mathrm{~W}, 2450 \mathrm{MHz}$. After cooking, the samples were in vitro digested by using a static system.

\subsection{In vitro digestion}

Cooked yolks and whites of poached and boiled eggs were separated and sampling was made by weighing both parts in the same proportion as they would appear in a whole cooked egg; in the case of the omelette, raw yolk and white were weighted and added to keep the same proportion of both parts as in the whole egg prior to preparation. The amount of cooked samples to be digested was weighted in order to have $0.35 \mathrm{~g}$ fat in each tube $(50 \mathrm{~mL}$ falcon tubes). Fat content in fresh and cooked eggs was determined 
previously at the digestion by the official Soxhlet method (AOAO, 2000). The digestion procedure used was based on the standardized static in vitro digestion method for food published by Minekus et al., (2014) with some modifications in order to allow analysing EPI conditions. Table 4.1 illustrates the amounts and composition of the fluids required in each of the stages of the digestion process. The digestion fluids were prepared fresh daily from stock solutions, salival (SSS), gastric (SGS) and intestinal (SIS) prepared according to Minekus et al., (2014). The enzymatic activity was tested before each experiment following the protocol proposed by Carrière et al., (2000). Each experimental condition was performed in triplicate. The in vitro digestion process was performed as follows:

Oral stage: Simulated salival fluid $(5 \mathrm{~mL})(\mathrm{SSF} ; \mathrm{pH} 8)$ at $37^{\circ} \mathrm{C}$, was added to the egg sample in a ratio 1:1 $(\mathrm{v} / \mathrm{w})$ and properly homogenized with a kitchen blender for 3 minutes (Vario Mixer, Ufesa $600 \mathrm{~W}$ ).

Gastric stage: After the oral stage, simulated gastric fluid (SGF; pH 3) was added to each tube containing the oral bolus $(1: 1 \mathrm{v} / \mathrm{w})$. Pepsin was added into the SGF to reach a concentration in the gastric mixture of $(2000 \mathrm{U} / \mathrm{mL})$. The $\mathrm{pH}$ of the mixtures was adjusted with $\mathrm{HCl}(1 \mathrm{~N})$ to $\mathrm{pH} 2.8 \pm 0.1$ and samples were flipped from top to bottom at $55 \mathrm{rpm}$ for $2 \mathrm{~h}$ at $37^{\circ} \mathrm{C}$ using an Intell-Mixer RM-2 (Elmi Ltd, Riga, LV-1006, Latvia) and incubated in a chamber Selecta (JP Selecta SA, Barcelona). These mixing conditions provided constant mechanical energy to induce the breakdown of the food matrix during digestion. The pancreatine supplement was added in the gastric stage in order to simulate swallowing the pill in case of EPI situations.

Intestinal stage: Following the gastric stage, simulated intestinal fluid (SIF; pH 7) was added in a proportion 1:1 (v/w) to each tube containing the gastric chime. The $\mathrm{pH}$ of the mixtures was adjusted to $\mathrm{pH} 6.0 \pm 0.1$ or $7.0 \pm 0.1$, depending on the conditions to be tested, with $\mathrm{NaOH}(1 \mathrm{~N})$. Samples were then being flipped from top to bottom at $55 \mathrm{rpm}$ for another $2 \mathrm{~h}$ at $37^{\circ} \mathrm{C}$. $\mathrm{pH}$ was monitored during the digestion process and readjusted if necessary to keep it constant (González-Bacerio, Rodríguez Hernández, \& del Monte Martínez, 2010; Prazeres, Garcia, \& Cabral, 1994). 
Table 4.1: Composition of simulated digestion fluids.

\begin{tabular}{llll}
\hline Constituent & $\begin{array}{l}\text { SSF } \\
\mathrm{mmol} / \mathrm{L}\end{array}$ & $\begin{array}{l}\text { SGF } \\
\mathrm{mmol} / \mathrm{L}\end{array}$ & $\begin{array}{c}\text { SIF } \\
\mathrm{mmol} / \mathrm{L}\end{array}$ \\
\hline $\mathrm{KCl}$ & 15.1 & 6.9 & 6.8 \\
$\mathrm{KH}_{2} \mathrm{PO}_{4}$ & 3.7 & 0.9 & 0.8 \\
$\mathrm{NaHCO}_{3}$ & 13.6 & 25 & 85 \\
$\mathrm{NaCl}$ & - & 47.2 & 38.4 \\
$\mathrm{MgCl}_{2}\left(\mathrm{H}_{2} \mathrm{O}\right)_{6}$ & 0.15 & 0.1 & 0.33 \\
$\left(\mathrm{NH}_{4}\right)_{2} \mathrm{CO}_{3}$ & 0.06 & 0.5 & - \\
$\mathrm{CaCl}_{2}$ & 1.5 & 0.15 & 0.6
\end{tabular}

The addition of pepsin, $\mathrm{Ca}^{2+}$ solution and water will result in the correct electrolyte concentration in the final digestion mixture. SSF: Simulated Salival Fluid; SGF: Simulated Gastric Fluid; SIF: Simulated Intestinal Fluid.

\subsection{Experimental design}

The experimental design for each type of cooked egg (boiled, poached and omelette) consisted on two main sets of experiments. In the first, intestinal conditions were fixed at $\mathrm{pH} 6$ and bile salts concentration $1 \mathrm{mM}$, and different pancreatin supplement doses $(0,1000,2000,3000$ and $4000 \mathrm{LU} / \mathrm{g}$ of lipid) were tested, in order to assess the influence of enzyme concentration. In the second, the dose of enzymes was fixed at $2000 \mathrm{LU} / \mathrm{g}$ of fat, and the study variables were different combinations of intestinal $\mathrm{pH}$ and bile concentration: $\mathrm{pH} 6 / 10 \mathrm{mM}, \mathrm{pH} 7 / 1 \mathrm{mM}$ and $\mathrm{pH} 7 / 10 \mathrm{mM}$, in order to analyse the impact of different intestinal scenarios on lipolysis, proteolysis, matrix degradation and lutein and zeaxanthin bioaccessibility. Of note, the combination $\mathrm{pH} 6 / 1 \mathrm{mM}$ would represent the most unfavourable condition in the gastrointestinal tract in EPI (Clarke, Stien, \& Walker, 2001; Gelfond, Ma, Semler, \& Borowitz, 2013; Norman, 1979; Robinson, Smith, \& Sly, 1990; Rovner, Schall, Mondick, Zhuang, \& Mascarenhas, 2013; $\mathrm{Vu}$ et al., 2000), and the $\mathrm{pH} 7 / 10 \mathrm{mM}$ would approach the standard duodenal conditions of a healthy adult. All the experiments were conducted in triplicate. 


\subsection{Analytical determinations}

\subsubsection{Matrix Degradation Index (MDI (\%))}

Matrix degradation Index was determined in all samples after in vitro digestion. This parameter represents the proportion of solids that were finely dispersed in the digested after the intestinal stage. The total content of a digestion tube was centrifuged (4000 x g-force for 20 minutes, $4{ }^{\circ} \mathrm{C}$ ) and filtered on a metallic sieve $(1.6 \mathrm{~mm} \times 1.6 \mathrm{~mm}$ mesh) to separate out large egg particles. The drained liquid, from now on called micellar phase, was collected and used to determine soluble protein in $12 \%$ trichloroacetic acid (TCA) $(5 \mathrm{ml})$, free fatty acids $(0.1 \mathrm{ml})$ and the remaining micellar phase was freeze-dried for xanthophylls determination. The egg particles were rinsed twice with $5 \mathrm{~mL}$ of appropriate juice to remove any digested material. Blotting paper was placed around the metallic sieve for $10 \mathrm{~min}$ to drain residual digestion juice. The egg particles were then transferred to an aluminum dish and immediately weighed. The aluminum dish was put in a forced air oven at $60^{\circ} \mathrm{C}$ for $48 \mathrm{~h}$ and weighed again to determine the mass of large egg solids. The matrix degradation index (MDI), corresponding to the proportion of egg solids passing the metallic sieve, was calculated according to Lamothe et al, 2012 (Lamothe, Azimy, Bazinet, Couillard, \& Britten, 2014; Lamothe, Corbeil, Turgeon, \& Britten, 2012).

\subsubsection{TCA soluble protein (\%)}

The extent of proteolysis was determined by measuring the protein soluble in TCA (Lamothe et al., 2014). TCA was added to digested samples to final concentration of $12 \%(\mathrm{w} / \mathrm{w})$. The mixture was vortexed, incubated for $15 \mathrm{~min}$ and filtered using a Whatman no. 40 filter paper. The fraction soluble in 12\% TCA was composed of small peptides and amino acid residues (Rowland, 1938). The filtrate was diluted in buffer (50 $\mathrm{mM}$ EDTA, $8 \mathrm{M}$ urea, $\mathrm{pH}=10$ ) and protein was determined by measuring absorption at $280 \mathrm{~nm}$ against a blank prepared with appropriate digestion fluids. A calibration line was determined using bovine serum albumin (BSA) as a standard. The results were reported as the percentage of the total protein concentration initially present in each tube. 


\subsubsection{Lipolysis extent (\%)}

Drained juice from digested samples was diluted 100-fold with a solution made of 5.6\% Triton X-100 and 6\% ethanol in water (Lamothe, Corbeil, Turgeon, \& Britten, 2012). This solution was used to solubilize the free fatty acids and stop lipase activity. Fatty acids release during digestion was measured on the diluted samples using a free fatty acid colorimetric assay kit (Roche Diagnostics, Indianapolis, IN, USA) and a spectrophotometer (UV/vis, Beckman Coulter) (Lamothe et al., 2014). Palmitic acid standard was used for quantitative determination of free fatty acids (FFA). FFA was expressed as the percentage of total fatty acids that could theoretically be released after complete digestion, assuming the maximum release of 2 fatty acids per triacylglycerol molecule and the average molecular weight of egg triglycerides $860 \mathrm{~g} \mathrm{~mol}^{-1}$ (Hunter, 2001).

\subsubsection{Xanthophylls bioaccesibility}

Initial lutein and zeaxanthin content in egg samples, raw and cooked, were characterized before and after digestion; samples were homogenized, placed immediately at $-40{ }^{\circ} \mathrm{C}$ and kept at that temperature for at least $48 \mathrm{~h}$ before freeze drying (48 h, $-45^{\circ} \mathrm{C}$ and $1 \mathrm{mBar}$ ). Freeze-dried samples were grounded to obtain a fine powder and they were stored at $-20^{\circ} \mathrm{C}$ before the analysis of lutein and zeaxanthin content. Extraction of xanthophylls: $6 \mathrm{ml}$ of methanol, acetone, and hexane $(1: 1: 1(\mathrm{v} / \mathrm{v} / \mathrm{v}))$ were added to a glass tube containing $0.15 \mathrm{~g}$ of freeze-dried powder. After addition of the solvent mixture, tubes were shaken in a vortex for $30 \mathrm{~s}$ and immediately afterwards they continued to be flipped from top to bottom at $55 \mathrm{rpm}$ for $30 \mathrm{~min}$. After this, $2 \mathrm{ml}$ of bidistilled water was added to each tube, and these were shaken for $1 \mathrm{~min}$ in the vortex mixer in order to separate the hydrosoluble and liposoluble phases adequately. Next, 1.5 $\mathrm{ml}$ of the non-polar phase containing the carotenoid pigments, were filtered with 0.22 mm nylon filters and transferred to amber HPLC glass vials. Hexane was then evaporated under Nitrogen flow and xanthophylls were re-suspended in $400 \mu \mathrm{L}$ of hexane. 
HPLC-DAD Analysis. Xanthophylls (Lutein and Zeaxanthin) were separated using a separation module (Waters, 2695) comprising a pump and DAD detector (2996, Waters, USA), using methanol, tert-methyl-butyl-ether and water as mobile phase (v:v:v), solvent A (83:15:2) and solvent B (8:90:2). Gradient elution was carried out as follows: $90 \% \mathrm{~A}, 0-15 \mathrm{~min} ; 90 \%$ to $5 \% \mathrm{~A}, 15-26 \mathrm{~min} ; 5 \%$ to $90 \%$ A (initial conditions), $26-$ $28 \mathrm{~min}$, at a flow rate of $1 \mathrm{~mL} / \mathrm{min}$, using a Develosil C30 Column $250 \mathrm{~mm} \times 4.6 \mathrm{~mm}$ i.d.5 $\mu \mathrm{m}$ (Phenomenex), and UV detection at $450 \mathrm{~nm}$. Each xanthophyll was quantified using a calibration curve of the pure standard. To evaluate the changes undergone by the xanthophylls, results were expressed as \% of bioaccessibility, defined as the percentage of lutein and zeaxanthin that are solubilized in the digestion fluids after the intestinal stage. Thus, this index defines the proportion of xanthophylls (lutein or zeaxanthin) that could become available for absorption into the systematic circulation. Samples were prepared in triplicate. Bioaccessibility (\%) was calculated according to Eq. (1) (Martínez-Las Heras, Pinazo, Heredia, \& Andrés, 2017; Ortega, Reguant, Romero, Macià, \& Motilva, 2009):

Bioaccessibility $(\%)=A / B \cdot 100$

Where, $\mathrm{A}$ is either lutein or zeaxanthin content $(\mu \mathrm{g} / \mathrm{g}$ product (boiled, poached or omelette egg) quantified in the supernatant at the end of gastrointestinal digestion, and $\mathrm{B}$ is either lutein or zeaxanthin content in boiled, poached or omelette egg before digestion and expressed in the same units.

Xanthophylls Quantification. Six-point standard calibration curves were prepared for quantification purposes. External calibration plots were recorded with sample concentrations ranging from 0.05 to $30.00 \mu \mathrm{g} / \mathrm{mL}$. Concentrations were calculated using the corresponding all-E standard calibration curves. The limit of detection (LOD) and limit of quantitation (LOQ) were determined by injecting a series of diluted solutions with known concentrations. LOD and LOQ were defined as the signal-to-noise ratio equal to 3 and 10 respectively, according to the International Conference on Harmonization (ICH) Guideline (Dixon, 1999). 


\subsection{Statistical analyses}

In order to study significant differences of the factors (enzyme dosage (LU/g fat), intestinal conditions of $\mathrm{pH}-$ bile concentration (6-1, 6-10, 7-1, 7-10) and cooking method (boiled, poached and omelette egg)), on MDI (\%), TCA soluble protein (\%), Lipolysis Extent (\%), Lutein and Zeaxanthin bioaccessibility (\%), a statistical analysis of variance (simple ANOVA) was performed using Statgraphics Centurion, with a confidence interval of $95 \%(\mathrm{p}<0.05)$. Additionally, a multi-factor analysis of variance (multivariate ANOVA) was also performed with a confidence interval of $99 \%(\mathrm{p}<0.001)$ in order to know out which factor ( $\mathrm{pH}$, bile or cooking method) affected the most (F-ratio) the studied parameters (MDI (\%), TCA soluble protein (\%), Lipolysis Extent (\%), Lutein and Zeaxanthin bioaccessibility (\%)). The multifactor ANOVA was applied only to the data obtained at a fixed dose of $2000 \mathrm{LU} / \mathrm{g}$ fat. All the experiments were performed at least in triplicate.

\section{RESULTS AND DISCUSSION}

\subsection{Influence of the intestinal conditions and cooking method on macronutrients digestibility}

Table 4.2 shows the results of the different digestibility parameters (MDI (\%), TCA soluble protein (\%) and lipolysis extent (\%)) obtained from varying the intestinal $\mathrm{pH}$ and bile concentration using a fixed pancreatic enzyme supplement dose of 2000 LU/g fat (average recommended value for EPI, (Turck et al., 2016)). Complementarily, Table 4.3 shows the F-ratio obtained from the multifactor ANOVA considering $\mathrm{pH}$, bile concentration and cooking method as factors and MDI (\%), TCA soluble protein (\%), Lipolysis Extent (\%), Lutein and Zeaxanthin bioaccessibility (\%) as response variables. The higher the F-ratio value, the higher the statistical significance of the factors on given response variables. Thus, bile concentration was the factor affecting the most both MDI (\%) and lipolysis extent; while cooking method presented a higher impact on proteolysis (TCA soluble protein). 
Table 4.2. Matrix degradation index (\%), TCA Soluble Protein (\%) and Lipolysis extent (\%), obtained for the different egg matrices after the in vitro digestion process using a fixed enzyme dose (2000 LU/g fat) and different duodenal conditions of $\mathrm{pH}$ and Bile concentration.

\section{Boiled Egg}

Poached Egg

Omelette Egg

\section{MDI (\%)}

pH $6-1 \mathrm{mM}$

$41 \pm 2^{\mathrm{aB}}$

$64 \pm 12^{\mathrm{aC}}$

$23.2 \pm 0.3^{\text {aA }}$

pH $6-10 \mathrm{mM}$

$71.23 \pm 0.03 \mathrm{bB}$

$73 \pm 10^{\mathrm{aC}}$

$25 \pm 4^{\text {aA }}$

pH 7 - $1 \mathrm{mM}$

$46 \pm 1 \mathrm{aB}$

$70 \pm 4^{\mathrm{aC}}$

$34.77 \pm 1.14^{\mathrm{aA}}$

$\mathrm{pH} 7-10 \mathrm{mM}$

$83 \pm 7^{\mathrm{cC}}$

$70 \pm 6^{\mathrm{aB}}$

$40 \pm 4^{\mathrm{aA}}$

\section{TCA Soluble protein (\%)}

\begin{tabular}{|c|c|c|c|c|c|}
\hline $\mathrm{pH} 6-1 \mathrm{mM}$ & $40.0 \pm 0.4^{\mathrm{aA}}$ & 58 & $\pm 2^{\mathrm{bB}}$ & 39 & $\pm 6^{\mathrm{aA}}$ \\
\hline pH $6-10 \mathrm{mM}$ & $50 \pm 2^{\mathrm{bB}}$ & 49 & $\pm 3^{\mathrm{aB}}$ & 36 & $\pm 2^{\mathrm{aA}}$ \\
\hline pH $7-1 \mathrm{mM}$ & $39 \pm 5^{\mathrm{aA}}$ & 68 & $\pm 1^{\mathrm{cC}}$ & 51 & $\pm 5^{\mathrm{bB}}$ \\
\hline pH $7-10 \mathrm{mM}$ & $57 \pm 6^{\mathrm{bB}}$ & 54 & \pm 4 bAB & 44 & $\pm 6^{\mathrm{abA}}$ \\
\hline
\end{tabular}

Lipolysis extent (\%)

$\begin{array}{llllll}\text { pH 6 - } 1 \mathrm{mM} & 30 \pm 7^{\mathrm{aA}} & 76 & \pm 8^{\mathrm{bC}} & 44 & \pm 3^{\mathrm{aB}} \\ \text { pH 6 - } 10 \mathrm{mM} & 78 \pm 14^{\mathrm{bB}} & 63 & \pm 2^{\mathrm{aB}} & 42 & \pm 5^{\mathrm{aA}} \\ \text { pH } 7-1 \mathrm{mM} & 28 \pm 4^{\mathrm{aA}} & 55 & \pm 2^{\mathrm{aB}} & 49 & \pm 9^{\mathrm{abB}} \\ \text { pH } 7-10 \mathrm{mM} & 87 \pm 12^{\mathrm{bB}} & 75 & \pm 8^{\mathrm{bB}} & 55 & \pm 3^{\mathrm{bA}}\end{array}$

Superscript letters (a-c) refer to the homogenous groups obtained for different duodenal conditions ( $\mathrm{pH}$ and Bile concentration) for the same egg matrix (boiled, poached and omelette) and at a statistical significance of $95 \%$ (p-value $<0.05$ ). Superscript letters (A-C) refer to the homogenous groups for different cooking methods at the same intestinal conditions and at a statistical significance of $95 \%$ (p-value $<0.05$ ). 
Table 4.3. F-ratio obtained from factorial ANOVA analysis for MDI (\%). TCA soluble protein, Lipolysis extent (\%) and Zeaxanthin and Lutein bioaccessibility (\%). The factors for the analysis were $\mathrm{pH}$, bile concentration and cooking method. The multifactor ANOVA was applied only to the data obtained at a fixed dose of $2000 \mathrm{LU} / \mathrm{g}$ fat.

\begin{tabular}{|c|c|c|c|c|c|c|c|c|c|c|}
\hline \multirow{2}{*}{$\begin{array}{l}\text { Principal } \\
\text { effects } \\
\mathrm{pH}\end{array}$} & \multicolumn{2}{|l|}{$\begin{array}{l}\text { MDI } \\
(\%)\end{array}$} & \multicolumn{2}{|c|}{$\begin{array}{l}\text { TCA soluble } \\
\text { protein } \\
(\%)\end{array}$} & \multicolumn{2}{|c|}{$\begin{array}{l}\text { Lipolysis } \\
\text { extent } \\
(\%)\end{array}$} & \multicolumn{2}{|c|}{$\begin{array}{l}\text { Lutein } \\
\text { bioaccessi- } \\
\text { bility (\%) }\end{array}$} & \multicolumn{2}{|c|}{$\begin{array}{l}\text { Zeaxanthin } \\
\text { bioaccessi- } \\
\text { bility (\%) }\end{array}$} \\
\hline & 16.3 & $*$ & 26.5 & $*$ & 1.04 & n.s. & 0.04 & ns & 3.6 & $\mathrm{~ns}$ \\
\hline Bile & 54.9 & $*$ & 0.36 & ns & 61.9 & $*$ & 57.89 & $*$ & 0.18 & $\mathrm{~ns}$ \\
\hline Cooking & 151 & $*$ & 46 & $*$ & 21.8 & $*$ & 18.54 & $*$ & 100.5 & $*$ \\
\hline
\end{tabular}

ns: non-statistical differences $(\mathrm{p}>0.05) .{ }^{*}: \mathrm{p}<0.001$.

The cooking method has a great impact on the matrix structure of the final egg product. Mixing of egg white and yolk for omelette preparation, as well as the different combinations of cooking temperature-time that were applied in each case (at $100^{\circ} \mathrm{C}$ for 10 minutes in boiled, at $100^{\circ} \mathrm{C}$ for 4 minutes in poached and $750 \mathrm{~W}$ for 80 seconds in omelette), result in different structural changes on egg proteins and lipids; then, different matrices with the same ingredients are obtained (with lower humidity in the case of the omelette, which dehydrates during cooking). Additionally, gastrointestinal digestion is a process that implies food interactions with biological fluids and their exposure to complex flow profiles and mechanical forces (Torcello-Gómez et al., 2011). The overall effect of both processes (cooking and digestion) was evaluated according to their Matrix Degradation Index (MDI (\%)). This parameter allows to measure the net result of the changes that take place during gastrointestinal digestion and to analyse the impact of cooking preparation (as food-related factor) and three host-related factors (intestinal $\mathrm{pH}$, bile concentration and pancreatic enzyme activity). In spite of the same composition, different matrices structure degrades in a different way during digestion. Poached egg, which yolk is still fluid showed the highest MDI. The degradation index of boiled egg was lower than poached due to the high coagulation of the white and the solidification of yolk, and even lower for omelette where yolk and white make up a more complex solid structure. The recent available evidence showing that structures of food matrices 
can modulate bioavailability of lipids, and other macro and micronutrients is based on the accessibility of digestive enzymes to the substrates. This is especially important in some chronic diseases that occur with EPI and require pancreatic enzyme supplementation. Our results reveal that for a certain enzyme dose the MDI and then the digestibility will be higher for poached and boiled egg than for omelette (Figure 4.2).

Additionally, results from in vitro digestion revealed that protein and lipid digestion are significantly affected by cooking method. Then, both host and food related factors should be taken into account to optimise egg fat and protein digestion. The highest proteolysis and lipolysis values were observed in poached egg and was the type of cooking that showed to be less dependent on intestinal conditions. According these results, poaching would be the most appropriated way of cooking eggs if the target is to maximize lipolysis, while omelette would be better for contrary purposes. 

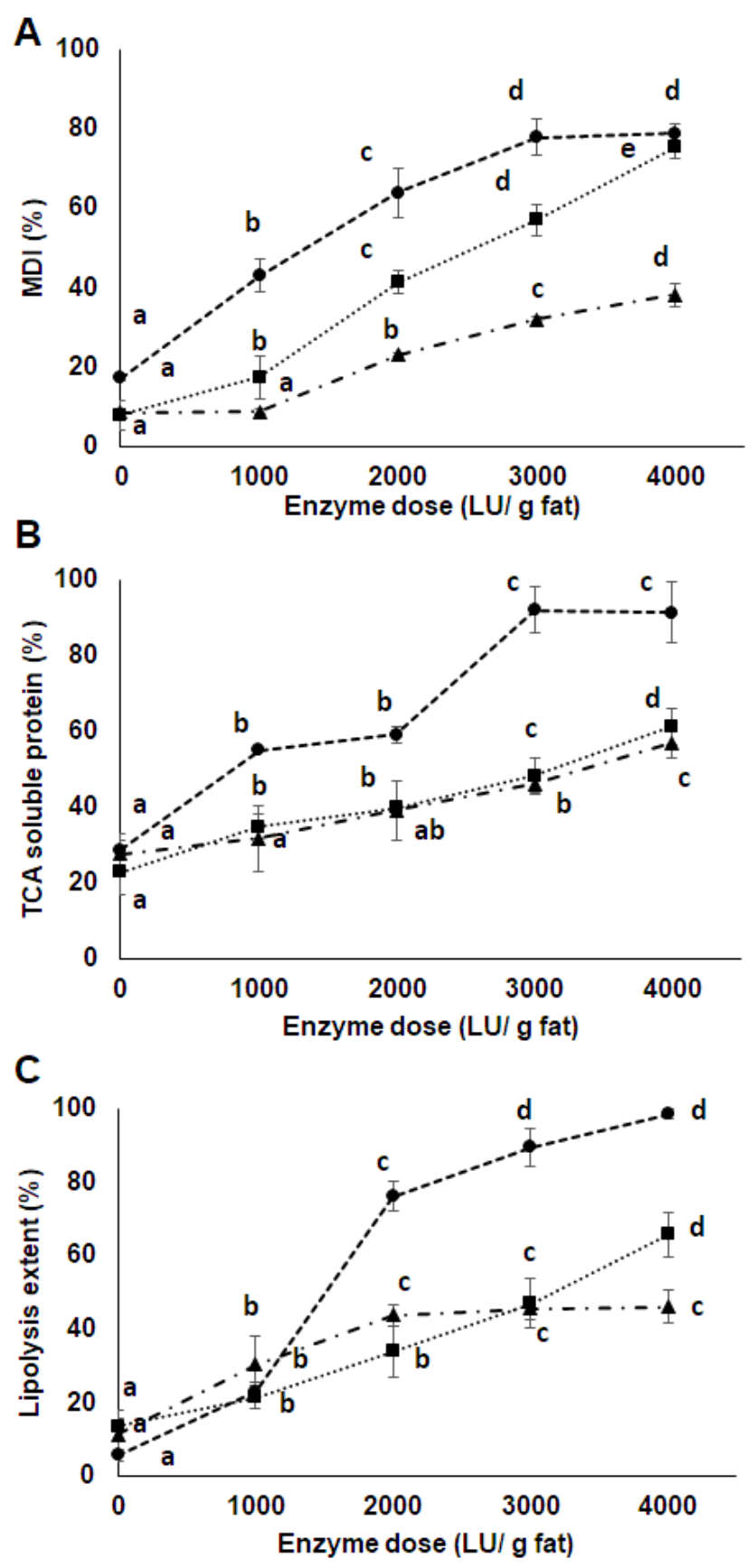

......Boiled Egg $\quad \rightarrow$ B..Poached Egg $\quad-\wedge-$ Omelette Egg

Figure 4.2. Matrix degradation index (\%) (A), TCA Soluble Protein (\%) (B) and Lipolysis extent $(\%)(C)$ obtained for the different egg matrices after in vitro digestion at fixed duodenal conditions of pH 6 and Bile concentration $1 \mathrm{mM}$ using different doses of Kreon (0-4000 LU/ g fat $\approx 0-57-$ 107-160-213 Protease Units / g of protein).

Letters (a-e) refer to the homogenous groups obtained for different doses $(0-4000)$ for the same egg matrix (boiled, poached and omelette) at a statistical significance of $95 \%$ ( $\mathrm{p}$-value $<0.05$ ). 
The higher the intensity of the cooking process (omelette>boiled $>$ poached) the lower the matrix degradation, even at the highest enzyme dose. These changes are related to the thermal denaturation of proteins, which interact to form insoluble aggregates. Concretely, the albumin coagulation depends on temperature as well as on cooking time (Matsudomi, Takahashi, \& Miyata, 2001). Moreover, the protein solubility of raw egg can decrease from $98 \%$ to $20 \%$ due to thermal treatment (Denmat, Anton, \& Gandemer, 1999; Llave, Fukuda, Fukuoka, Shibata-Ishiwatari, \& Sakai, 2018; Van Der Plancken, Van Loey, \& Hendrickx, 2006). These protein changes are also observed in TCA soluble protein results; no differences between boiled and omelette was observed, and the poached egg samples reached the highest TCA soluble protein values at and above 3000 $\mathrm{LU} / \mathrm{g}$ fat. Additionally, denatured egg yolk proteins can adsorb at the $\mathrm{o} / \mathrm{w}$ interface this affecting lipolysis extent at low bile concentrations. This could probably explain the differences observed between lipids digestion in poached and boiled or omelette. In omelette egg, the mixing step previous to the heating process favours the lipids from egg yolk being trapped within the coagulated protein matrix, further reducing the accessibility of the enzymes to lipids. It can be noticed that matrix degradation, and therefore MDI (\%), occurs even in absence of pancreatic enzymes. In this context, the simulated gastric stirring together with the previous pepsin action during the gastric stage could be responsible for the MDI (\%) value obtained. This is in accordance to the results obtained for TCA soluble protein values for the dose of $0 \mathrm{LU} / \mathrm{g}$ fat, which indicates that proteolysis partially occurred during the gastric stage (about 29\% for poached egg, 23\% for boiled egg and $28 \%$ for omelette, (Figure 4.2b). After the intestinal stage, however, it ranged from a minimum to a maximum of 40 and $90 \%$, depending on the type of processing and enzymatic supplement concentration (Figure 4.2b). Increased supplement dose generated a higher proteolysis in all cooking eggs (boiled, poached and omelette), being almost $100 \%$ in poached egg. In case of boiled egg and omelette using a $4000 \mathrm{LU} / \mathrm{g}$ fat reached similar TCA soluble protein (\%) values to achieved in poached egg using $2000 \mathrm{LU} / \mathrm{g}$ fat. As it has been mentioned above, this fact seems to be related to the structural changes in egg matrix caused by the cooking method. Cooking involves 
the use of high temperatures that could modified native protein structure resulting in protein aggregates, which might interfere in protein and lipid digestion. Van der Plancken et al. (2006) reported that only $20 \%$ of egg proteins remained soluble after 10 min at $80^{\circ} \mathrm{C}$. Therefore, it is expected a percentage of soluble protein even inferior after cooking treatment at $100{ }^{\circ} \mathrm{C}$. For this reason, protein and lipid digestibility are affected by cooking conditions and it is important to consider the time and temperature that egg have been subjected.

The interactions generated among macronutrients during cooking as well as the chemical modifications undergone by proteins, significantly affected the amount of protein digested $(\mathrm{p}<0.05)$. At the end of the digestion, no significant differences were found in the proteolysis achieved between both, omelette and boiled eggs, $(p<0.05)$ at the same enzymatic supplement concentration (Figure 4.1b).

Regarding the effect of the dose of enzymatic supplement on proteolysis, an increase from 0 to $2000 \mathrm{LU} / \mathrm{g}$ fat (0 to 106.6 protease units'/ g protein) resulted in higher proteolysis values and especially for poached eggs. The softer thermal treatment (in terms of time and/or temperature) of poached egg results in less denaturation and gelation of proteins than in omelette or boiled eggs. The higher temperature applied for boiled and omelette preparations could lead to a coagulation of proteins with an increase of the viscosity, as well as to the formation of aggregates and to a subsequent gelation due to the hydrophobic interactions and the formation of disulphide bonds (Guilmineau \& Kulozik, 2006; Kiosseoglou \& Parakevopoulou, 2005). The obtained results confirm therefore, that lower denaturation and gelation of proteins allows the matrix for a greater facility to be digested during the intestinal stage. These results are in agreement with previous studies were gelation by heat treatment of protein based products lead to an increase in their mean retention time in the stomach, this leading to lower levels of amino acid absorption (Barbé et al., 2013, 2014). These findings have to be taken into account as this delay and lower amino acid bioavailability might have substantial effects on the protein metabolism. Likewise, a slight increase in TCA soluble protein values could be observed by increasing the $\mathrm{pH}$ from 6 to 7 in the case of poached egg and omelette, as well as by increasing the bile concentration when digesting the boiled egg. Comparing 
the results at $\mathrm{pH}$ 6-1 $\mathrm{mM}$ bile (exocrine pancreatic insufficiency) with $\mathrm{pH}$ 7-10 $\mathrm{mM}$ bile (standard healthy conditions), the digestibility of egg lipids only seems to be compromised in the consumption of boiled eggs.

According to our results from lipolysis extent (\%), it can be concluded that differences in bile concentration, from $10 \mathrm{mM}$ to $1 \mathrm{mM}$, greatly affects the extent of lipolysis in boiled and omelette eggs, while no significant influence of the duodenal $\mathrm{pH}$ was found $(p>0.05)$. The role of bile concentration on lipolysis was much higher in boiled eggs in which fat globules are coagulated in yolk, requiring high concentrations of bile to be emulsified and to be more accessible for lipases. Regardless intestinal $\mathrm{pH}$ or bile concentration, $2000 \mathrm{LU} / \mathrm{g}$ fat seems no to be enough for a complete lipid digestion in egg products. Moreover, an increase on the dose of enzymatic supplement to 4000 $\mathrm{LU} / \mathrm{g}$ fat, only promotes a complete lipid digestion (lipolysis close to $100 \%$ ) in poached eggs whereas for boiled or omelette the highest extent of lipolysis achieved were $\approx 66$ and $42 \%$, respectively. This could be explained by the capacity of some proteins such ovalbumin to bind hydrophobic compounds (for instance stearic acid) forming complexes that could modify nutrients availability during digestion (Sponton, Perez, Carrara, \& Santiago, 2015). In the case of omelette and boiled eggs, where proteins are highly coagulated, these complexes formed within proteins and lipids could lead to the decrease of lipids availability.

\subsection{Influence of the intestinal conditions and cooking method on carotenoid bioaccessibility}

Lutein and zeaxanthin constitute the main xanthophylls in egg yolk (Schlatterer \& Breithaupt, 2006), while other xanthophylls, such as 13'-Z-lutein, and 13-Zzeaxanthin, all-E-canthaxanthin or all-E- $\beta$ - apo- 8 ' carotenoic acid ethyl ester, are in much lower amounts. Additionally, no significant trans-cis isomerization of xanthophylls previously reported during digestion (Granado-Lorencio et al., 2007, 2010; Nimalaratne et al., 2015). Thus, the impact of the intestinal conditions on xanthophylls bioaccessibility in eggs has been focused on lutein and zeaxanthin compounds, and the bioaccessibility assessed from the chromatographic quantification of trans isomer of 
each respective carotenoid. In this context, the LOD and LOQ were found to be 0.032 and $0.12(\mu \mathrm{g} / \mathrm{mL})$ for lutein and 0.033 and $0.103(\mu \mathrm{g} / \mathrm{mL})$ for zeaxanthin respectively, and the concentration of both xanthophylls in the extracts was always above the LOQ. According to our results (Table 4.4), lutein and zeaxanthin contents in raw egg (mean value of 0.27 and $0.35 \mu \mathrm{g} / \mathrm{g}$, respectively) were similar to those reported by other authors (Handelman et al., 1999; Nimalaratne \& Wu, 2015), although they could be significantly affected by hens' feed composition. With regard to the influence of the cooking method (boiling, poaching, and microwaving), it could be affirmed that all methods preserved the xanthophylls content ( $\mu \mathrm{g} / \mathrm{g}$ of dry matter). The carotenoid stability during cooking has been also reported in the study carried out by Nimalaratne et al. (2012) in which a slight decrease of lutein and zeaxanthin contents (6-20\%), was found as a consequence of cooking. It is important to point out, the higher intake of xanthophylls per gram of omelette compared to the ingestion of one gram of raw, boiled or poached egg (values of $\mu \mathrm{g} / \mathrm{g}$ product) as a result of the concentration taking place during cooking by microwaves due to the loss of water.

Table 4.4. Lutein and Zeaxanthin content in raw egg, boiled, poached and omelette before digestion. Contents are expressed in $\mu \mathrm{g} / \mathrm{g}$ product and $\mu \mathrm{g} / \mathrm{g}$ dry matter.

\begin{tabular}{ccccc}
\hline & \multicolumn{2}{c}{ Lutein } & \multicolumn{2}{c}{ Zeaxanthin } \\
& $(\boldsymbol{\mu g} / \mathbf{g}$ product$)$ & $(\boldsymbol{\mu g} / \mathbf{g}$ dry matter $)$ & $(\boldsymbol{\mu g} / \mathbf{g}$ product $)$ & $(\boldsymbol{\mu g} / \mathbf{g}$ dry matter $)$ \\
\hline Raw egg & $0.27 \pm 0.09^{\mathrm{a}}$ & $1.2 \pm 0.3^{\mathrm{a}}$ & $0.35 \pm 0.18^{\mathrm{a}}$ & $1.5 \pm 0.7^{\mathrm{a}}$ \\
Boiled & $0.25 \pm 0.04^{\mathrm{a}}$ & $0.89 \pm 0.15^{\mathrm{a}}$ & $0.38 \pm 0.08^{\mathrm{a}}$ & $1.3 \pm 0.3^{\mathrm{a}}$ \\
Poached & $0.27 \pm 0.09^{\mathrm{a}}$ & $0.9 \pm 0.3^{\mathrm{a}}$ & $0.35 \pm 0.06^{\mathrm{a}}$ & $1.3 \pm 0.2^{\mathrm{a}}$ \\
Omelette & $0.67 \pm 0.17^{\mathrm{b}}$ & $1.1 \pm 0.3^{\mathrm{a}}$ & $0.68 \pm 0.17^{\mathrm{b}}$ & $1.14 \pm 0.16^{\mathrm{a}}$ \\
\hline
\end{tabular}

Superscript letters $(a-b)$ refer to the homogeneous groups obtained by the ANOVA (p-value $<0.05$ ).

Table 4.5 gathers the influence of intestinal conditions of $\mathrm{pH}$ and bile concentration as well as enzymatic dosage of Kreon on lutein and zeaxanthin bioaccessibility (\%). With regard to the effect of the dosage of the enzymatic supplement under intestinal $\mathrm{pH}$ of 6 and bile concentration of $1 \mathrm{mM}$, bioaccessibility of both 
xanthophylls seems to follow a similar trend to that observed for lipids digestion as it was expected due to the fat-soluble nature of these antioxidants. Thus, the solubility and extractability of xanthophylls from boiled and poached eggs seems to increase as it does the dose of the enzyme supplement from 0 to $3000 \mathrm{LU} / \mathrm{g}$ fat; whereas in omelette, the maximum bioaccessibility of xanthophylls was reached at $1000 \mathrm{LU} / \mathrm{g}$ fat. When the digestibility of both xanthophylls is compared, zeaxanthin appears to be slightly more bioaccessible than lutein in poached and omelette eggs at 2000, 3000 and $4000 \mathrm{LU} / \mathrm{g}$ fat. Apparently, lutein and zeaxanthin may exhibit different orientations in the phospholipid bilayer, which might contribute to their different bioaccessibility (Britton, Liaaen-Jensen, \& Pfander, 2008; Nimalaratne et al., 2015). 
Table 4.5. Lutein and Zeaxanthin bioaccessibility (\%) as a function of different doses of Kreon (0-4000 LU/g fat) and intestinal conditions of $\mathrm{pH}$ (6 and 7) and bile concentration (1 and $10 \mathrm{mM})$.

\begin{tabular}{|c|c|c|c|}
\hline & \multicolumn{3}{|c|}{ Lutein Bioaccesibility (\%) } \\
\hline & Boiled Egg & Poached Egg & Omelette Egg \\
\hline \multicolumn{4}{|c|}{ Enzyme dose (LU/g fat) } \\
\hline 0 & $27 \pm 2^{\mathrm{aA}}$ & $30 \pm 2^{\mathrm{aA}}$ & $35 \pm 7$ bA \\
\hline 1000 & $41 \pm 3^{\mathrm{bA}}$ & $38 \pm 11^{\mathrm{aA}}$ & $37 \pm 4^{\mathrm{bA}}$ \\
\hline 2000 & $66 \pm 7^{\mathrm{cB}}$ & $70 \pm 11 \mathrm{bB}$ & $19 \pm 7^{\mathrm{aA}}$ \\
\hline 3000 & $80 \pm 8^{\mathrm{dB}}$ & $99 \pm 5^{\mathrm{cC}}$ & $28 \pm 6^{\mathrm{abA}}$ \\
\hline 4000 & $84 \pm 8 \mathrm{~dB}$ & $91 \pm 14^{\mathrm{bcB}}$ & $22 \pm 2^{\mathrm{aA}}$ \\
\hline \multicolumn{4}{|c|}{ Intestinal conditions $\mathbf{p H}-$ Bile $\mathbf{m M}$} \\
\hline $6-1$ & $66 \pm 7^{\mathrm{aB}}$ & $70 \pm 11^{\mathrm{aB}}$ & $19 \pm 7^{\mathrm{aA}}$ \\
\hline $6-10$ & $59 \pm 10^{\mathrm{aB}}$ & $69 \pm 3^{\mathrm{aA}}$ & $33 \pm 9^{b B}$ \\
\hline $7-1$ & $65 \pm 11^{\mathrm{aA}}$ & $92 \pm 10^{\mathrm{bB}}$ & $83 \pm 3 \mathrm{dAB}$ \\
\hline $7-10$ & $104 \pm 21^{\mathrm{bB}}$ & $57 \pm 10^{\mathrm{aA}}$ & $69 \pm 7^{\mathrm{cA}}$ \\
\hline
\end{tabular}

\begin{tabular}{|c|c|c|c|}
\hline & \multicolumn{3}{|c|}{ Zeaxanthin Bioaccesibility (\%) } \\
\hline & Boiled Egg & Poached Egg & Omelette Egg \\
\hline \multicolumn{4}{|c|}{ Enzyme dose (LU/g fat) } \\
\hline 0 & $26 \pm 0^{\mathrm{aA}}$ & $28 \pm 8^{\mathrm{aAB}}$ & $43 \pm 11^{\mathrm{aB}}$ \\
\hline 1000 & $48 \pm 1^{\mathrm{bB}}$ & $32 \pm 3^{\mathrm{aA}}$ & $61 \pm 7^{\mathrm{bC}}$ \\
\hline 2000 & $63 \pm 5^{\mathrm{cAB}}$ & $65 \pm 13^{\mathrm{bB}}$ & $31 \pm 7^{\mathrm{aA}}$ \\
\hline 3000 & $70 \pm 2 \mathrm{~dB}$ & $103 \pm 17^{b C}$ & $45 \pm 13^{a b A}$ \\
\hline 4000 & $77 \pm 5^{\mathrm{dB}}$ & $98 \pm 7^{\mathrm{bC}}$ & $34 \pm 7^{\mathrm{aA}}$ \\
\hline \multicolumn{4}{|c|}{ Intestinal conditions $\mathbf{p H}-$ Bile $\mathbf{m M}$} \\
\hline $6-1$ & $63 \pm 5^{\mathrm{aB}}$ & $65 \pm 13^{\mathrm{aB}}$ & $31 \pm 7^{\mathrm{aA}}$ \\
\hline $6-10$ & $67 \pm 7 \mathrm{aB}$ & $70 \pm 4^{\mathrm{bB}}$ & $47 \pm 8^{\mathrm{bA}}$ \\
\hline $7-1$ & $62 \pm 6^{\mathrm{aA}}$ & $86 \pm 3^{\mathrm{bB}}$ & $111 \pm 12^{\mathrm{aAB}}$ \\
\hline $7-10$ & $98 \pm 16^{\mathrm{bB}}$ & $65 \pm 6^{\text {aA }}$ & $106 \pm 13^{\mathrm{bB}}$ \\
\hline
\end{tabular}

$\overline{\text { Superscript letters (a-d) refer to the homogenous groups obtained for different doses }(0-4000) \text { or }}$ duodenal conditions ( $\mathrm{pH}$ and Bile concentration) for the same egg matrix (boiled, poached and omelette) and at a statistical significance of $95 \%$ (p-value $<0.05$ ). Superscript letters (A-C) refer to the homogenous groups for different cooking methods at the same dose or intestinal conditions and at a statistical significance of $95 \%$ (p-value $<0.05)$. 
The effect of intestinal $\mathrm{pH}$ and bile concentration on xanthophylls bioaccessibility was dependent on the egg matrix. The results obtained from the multifactorial ANOVA showed a significant influence $(\mathrm{p}<0.001)$ of cooking method on the bioaccessibility of lutein and zeaxanthin; while only the lutein bioaccessibility was significantly affected $(\mathrm{p}<0.001)$ by bile concentration (Table 4.3 ).

Boiling process resulted in higher bioaccessibility of lutein and zeaxanthin, under standard intestinal conditions of $\mathrm{pH} 7$ and bile concentration of $10 \mathrm{mM}$ when compared to the other intestinal scenarios $(\mathrm{pH} 6 / 1 \mathrm{mM}$ or $10 \mathrm{mM}$ and $\mathrm{pH}$ 7/ $1 \mathrm{mM})$. In poached egg, neither $\mathrm{pH}$ nor bile concentration seems to present a significant influence on xanthophylls bioaccessibility, even if slight higher values were found at $\mathrm{pH} 7$ and bile concentration of $1 \mathrm{mM}$. Finally, a notable increase of xanthophylls bioaccessibility was found when omelette was digested at $\mathrm{pH} 7$ instead of 6 . This fact could be linked to the higher digestibility of macronutrients (Table 4.2) in omelette, both lipids and proteins, at $\mathrm{pH} 7$ than at 6, leading to a higher release of micronutrients at this $\mathrm{pH}$ (Peinado, Larrea, Heredia, \& Andrés, 2018).

Of notice, chemical and structural changes of proteins and lipoproteins in egg yolk occurring during different cooking conditions will influence the micellarization

efficiency (Nimalaratne et al., 2015) giving as a result higher carotenoid bioaccessibility in boiled eggs and poached eggs than in omelette, excepting at $\mathrm{pH} 7$ at $2000 \mathrm{LU} / \mathrm{g}$ fat. Concretely, the homogenization during omelette preparation, together with the thermal treatment, could increase the interaction among ingredients and therefore matrix consistency, generating a network that might entrap the carotenoids (Panozzo et al., 2013), leading to a lower bioaccessibility.

\section{CONCLUSIONS}

From the present study, it could be concluded that both structural changes undergone by egg matrix during cooking and the host intestinal conditions highly affect the digestibility and bioaccessibility of macro and micronutrients. To this regard, omelette cooking and boiling resulted in lower digestibility of lipids and protein compared to poaching after in vitro digestion under exocrine pancreatic insufficiency 
(EPI) conditions. Thus, the highest lipolysis (100\%) was registered for poached eggs under the highest dose of enzyme supplementation of pancreatin (4000 LU / g fat).

In the same way, xanthophylls bioaccessibility was also affected by cooking method, registering the highest bioaccessibility of lutein and zeaxanthin in boiled and poached egg. Xanthophylls bioaccessibility of boiled and omelette eggs was significantly lower when in vitro digested under EPI. Additionally, $\mathrm{pH} 7$ seems to greatly favour xanthophylls bioaccessibility in omelette eggs compared to $\mathrm{pH}$ 6; while lutein bioaccessibility was positively and significantly affected by bile concentration.

To sum up, it is expected that these results help to adjust the dosage of pancreatic supplementation for individuals with exocrine insufficiency taking into account the preparation method. In this context, poached egg would be the most advisable under these intestinal conditions in terms of fat and protein digestibility.

\section{ACKNOWLEDGEMENTS}

Authors of this paper, on behalf of MyCyFAPP consortium, acknowledge the European Union and the Horizon 2020 Research and Innovation Framework Programme for funding the above-mentioned project under grant agreement number 643806. The authors would like to thank the Conselleria de Educació i Investigació de la Generalitat Valenciana for the PhD scholarship given to Andrea Asensio Grau.

\section{REFERENCES}

AOAC (2000). Official methods of analysis of AOAC International. (17th ed.). Gaithersberg, Maryland: Association of Official Chemists.

Armand, Fieker, A. P., \& Philpott, J. (2011). Enzyme replacement therapy for pancreatic insufficiency: present and future. Clinical and Experimental Gastroenterology, 4(1), 55. https://doi.org/10.2147/CEG.S17634

Barbé, F., Ménard, O., Gouar, Y. Le, Buffière, C., Famelart, M.-H., Laroche, B., ... Dupont, D. (2014). Acid and rennet gels exhibit strong differences in the kinetics of milk protein digestion and amino acid bioavailability. Food Chemistry, 143, 1-8. https://doi.org/10.1016/j.foodchem.2013.07.100 
Barbé, F., Ménard, O., Le Gouar, Y., Buffière, C., Famelart, M.-H., Laroche, B., ... Rémond, D. (2013). The heat treatment and the gelation are strong determinants of the kinetics of milk proteins digestion and of the peripheral availability of amino acids. Food Chemistry, 136(3-4), 1203-1212. https://doi.org/10.1016/j.foodchem.2012.09.022

Britton, G., Liaaen-Jensen, S., \& Pfander, H. (2008). Carotenoids. In G. Britton, S. Liaaen-Jensen, \& H. Pfander (Eds.), Carotenoids (Vol. 4, pp. 1-30). Cambridge: Cambridge University Press.

Carrière, F., Renou, C., Lopez, V., De Caro, J., Ferrato, F., Lengsfeld, H., ... Verger, R. (2000). The specific activities of human digestive lipases measured from the in vivo and in vitro lipolysis of test meals. Gastroenterology, 119(4), 949-960. https://doi.org/10.1053/gast.2000.18140

Chung, H.-Y., Rasmussen, H. M., \& Johnson, E. J. (2004). Lutein bioavailability is higher from lutein-enriched eggs than from supplements and spinach in men. The Journal of Nutrition, 134(8), 1887-93.

Clarke, L. L., Stien, X., \& Walker, N. M. (2001). Intestinal bicarbonate secretion in cystic fibrosis mice. JOP : Journal of the Pancreas, 2(4), 263-267.

Denmat, M. Le, Anton, M., \& Gandemer, G. (1999). Protein Denaturation and Emulsifying Properties of Plasma and Granules of Egg Yolk as Related to Heat Treatment. Journal of Food Science, 64(2), 194-197. https://doi.org/10.1111/j.13652621.1999.tb15863.x

Dixon, J. R. (1999). The international conference on harmonization good clinical practice guideline. Quality Assurance: Good Practice, Regulation, and Law, 6(2), 6574. https://doi.org/10.1080/105294199277860

Dugave, C., \& Demange, L. (2003). Cis-Trans Isomerization of Organic Molecules and Biomolecules: Implications and Applications †. Chemical Reviews, 103(7), 24752532. https://doi.org/10.1021/cr0104375

Faulks, R. M., \& Southon, S. (2005). Challenges to understanding and measuring carotenoid bioavailability. Biochimica et Biophysica Acta (BBA) - Molecular Basis of Disease, 1740(2), 95-100. https://doi.org/10.1016/j.bbadis.2004.11.012 
Gelfond, D., Ma, C., Semler, J., \& Borowitz, D. (2013). Intestinal ph and gastrointestinal transit profiles in cystic fibrosis patients measured by wireless motility capsule. Digestive Diseases and Sciences, 58(8), 2275-2281. https://doi.org/10.1007/s10620-012-2209-1

González-Bacerio, J., Rodríguez Hernández, J., \& del Monte Martínez, A. (2010). Lipases: enzymes with potential for the development of immobilized biocatalysts by interfacial adsorption. Revista Colombiana de Biotecnología, 12(1), 113-140.

Granado-Lorencio, F., López-López, I., Herrero-Barbudo, C., Blanco-Navarro, I., Cofrades, S., Pérez-Sacristán, B., ... Jiménez-Colmenero, F. (2010). Lutein-enriched frankfurter-type products: Physicochemical characteristics and lutein in vitro bioaccessibility. Food Chemistry, 120(3), 741-748. https://doi.org/10.1016/j.foodchem.2009.11.005

Granado-Lorencio, F., Olmedilla-Alonso, B., Herrero-Barbudo, C., Pérez-Sacristán, B., Blanco-Navarro, I., \& Blázquez-García, S. (2007). Comparative in Vitro Bioaccessibility of Carotenoids from Relevant Contributors to Carotenoid Intake. Journal of Agricultural and Food Chemistry, 55(15), 6387-6394. https://doi.org/10.1021/jf070301t

Guilmineau, F., \& Kulozik, U. (2006). Impact of a thermal treatment on the emulsifying properties of egg yolk. Part 2: Effect of the environmental conditions. Food Hydrocolloids, 20(8), 1114-1123. https://doi.org/10.1016/j.foodhyd.2005.12.006

Handelman, G., Nightingale, Z., Lichtenstein, A., Schaefer, E., \& Blumberg, J. (1999). Lutein and zeaxanthin concentrations in plasma after dietary supplementation with egg yolk. American Journal of Clinical Nutrition, 70(2), 247-251.

Hunter, E. J. (2001). Studies on effects of dietary fatty acids as related to their position on triglycerides. Lipids, 36(7), 655-668. https://doi.org/10.1007/s11745-0010770-0

Hur, S. J., Lim, B. O., Decker, E. A., \& McClements, D. J. (2011). In vitro human digestion models for food applications. Food Chemistry, 125(1), 1-12. https://doi.org/10.1016/j.foodchem.2010.08.036 
Kiosseoglou, V., \& Parakevopoulou, A. (2005). Molecular interactions in gels prepared with egg yolk and its fractions. Food Hydrocolloids, 19(3), 527-532. https://doi.org/10.1016/j.foodhyd.2004.10.027

Lamothe, S., Azimy, N., Bazinet, L., Couillard, C., \& Britten, M. (2014). Interaction of green tea polyphenols with dairy matrices in a simulated gastrointestinal environment. Food \& Function, 5(10), 2621-2631. https://doi.org/10.1039/c4fo00203b

Lamothe, S., Corbeil, M.-M., Turgeon, S. L., \& Britten, M. (2012a). Influence of cheese matrix on lipid digestion in a simulated gastro-intestinal environment. Food \& Function, 3(7), 724. https://doi.org/10.1039/c2fo10256k

Lamothe, S., Corbeil, M.-M., Turgeon, S. L., \& Britten, M. (2012b). Influence of cheese matrix on lipid digestion in a simulated gastro-intestinal environment. Food $\{\&\}$ Function, 3(7), 724-731. https://doi.org/10.1039/c2fo10256k

Layer, P., \& Keller, J. (2003). Lipase Supplementation Therapy: Standards, Alternatives, and Perspectives. Pancreas, 26(1), 1-7. https://doi.org/10.1097/00006676200301000-00001

Llave, Y., Fukuda, S., Fukuoka, M., Shibata-Ishiwatari, N., \& Sakai, N. (2018). Analysis of color changes in chicken egg yolks and whites based on degree of thermal protein denaturation during ohmic heating and water bath treatment. Journal of Food Engineering, 222, 151-161. https://doi.org/10.1016/j.jfoodeng.2017.11.024

Martínez-Las Heras, R., Pinazo, A., Heredia, A., \& Andrés, A. (2017). Evaluation studies of persimmon plant (Diospyros kaki ) for physiological benefits and bioaccessibility of antioxidants by in vitro simulated gastrointestinal digestion. Food Chemistry, 214, 478-485. https://doi.org/10.1016/j.foodchem.2016.07.104

Matsudomi, N., Takahashi, H., \& Miyata, T. (2001). Some structural properties of ovalbumin heated at 80 degrees $\mathrm{C}$ in the dry state. Food Research International, 34(23), 229-235. https://doi.org/10.1016/S0963-9969(00)00157-5

Minekus, M., Alminger, M., Alvito, P., Ballance, S., Bohn, T., Bourlieu, C., ... Brodkorb, A. (2014). A standardised static in vitro digestion method suitable for food an international consensus. Food Funct. Food Funct, 5(5), 1113-1124. https://doi.org/10.1039/c3fo60702j 
Naikwade, S. R., Meshram, R. N., \& Bajaj, A. N. (2009). Preparation and In Vivo Efficacy Study of Pancreatin Microparticles as an Enzyme Replacement Therapy for Pancreatitis. Drug Development and Industrial Pharmacy, 35(4), 417-432. https://doi.org/10.1080/03639040802422104

Nimalaratne, C., Lopes-Lutz, D., Schieber, A., \& Wu, J. (2012). Effect of Domestic Cooking Methods on Egg Yolk Xanthophylls. Journal of Agricultural and Food Chemistry, 60(51), 12547-12552. https://doi.org/10.1021/jf303828n

Nimalaratne, C., Savard, P., Gauthier, S. F., Schieber, A., \& Wu, J. (2015). Bioaccessibility and Digestive Stability of Carotenoids in Cooked Eggs Studied Using a Dynamic in Vitro Gastrointestinal Model. Journal of Agricultural and Food Chemistry, 63(11), 2956-2962. https://doi.org/10.1021/jf505615w

Nimalaratne, C., \& Wu, J. (2015). Hen Egg as an Antioxidant Food Commodity: A Review. Nutrients, 7(10), 8274-8293. https://doi.org/10.3390/nu7105394

Norman, A. P. (1979). Intestinal bile salts in cystic fibrosis, 19-24.

Ortega, N., Reguant, J., Romero, M.-P., Macià, A., \& Motilva, M.-J. (2009). Effect of Fat Content on the Digestibility and Bioaccessibility of Cocoa Polyphenol by an in Vitro Digestion Model. Journal of Agricultural and Food Chemistry, 57(13), 57435749. https://doi.org/10.1021/j9900591q

Panozzo, A., Lemmens, L., Van Loey, A., Manzocco, L., Nicoli, M. C., \& Hendrickx, M. (2013). Microstructure and bioaccessibility of different carotenoid species as affected by high pressure homogenisation: A case study on differently coloured tomatoes. Food Chemistry, 141(4), 4094-4100. https://doi.org/10.1016/j.foodchem.2013.06.099

Peinado, I., Larrea, V., Heredia, A., \& Andrés, A. (2018). Lipolysis kinetics of milkfat catalyzed by an enzymatic supplement under simulated gastrointestinal conditions. Food Bioscience, 23(January), 1-8. https://doi.org/10.1016/j.fbio.2018.02.011

Pineda-Vadillo, C., Nau, F., Guerin-Dubiard, C., Jardin, J., Lechevalier, V., SanzBuenhombre, M., ... Dupont, D. (2017). The food matrix affects the anthocyanin profile of fortified egg and dairy matrices during processing and in vitro digestion. Food Chemistry, 214, 486-496. https://doi.org/10.1016/j.foodchem.2016.07.049 
Prazeres, D. M. F., Garcia, F. A. P., \& Cabral, M. S. (1994). Continuous lipolysis in a reversed micellar membrane bioreactor. Bioprocess Engineering, 10, 21-27.

Robinson, P. J., Smith, A. L., \& Sly, P. D. (1990). Duodenal pH in cystic fibrosis and its relationship to fat malabsorption. Digestive Diseases and Sciences, 35(10), 1299 1304. https://doi.org/10.1007/BF01536423

Rodríguez-Roque, M. J., de Ancos, B., Sánchez-Moreno, C., Cano, M. P., ElezMartínez, P., \& Martín-Belloso, O. (2015). Impact of food matrix and processing on the in vitro bioaccessibility of vitamin $\mathrm{C}$, phenolic compounds, and hydrophilic antioxidant activity from fruit juice-based beverages. Journal of Functional Foods, 14, 33-43. https://doi.org/10.1016/j.jff.2015.01.020

Rovner, A. J., Schall, J. I., Mondick, J. T., Zhuang, H., \& Mascarenhas, M. R. (2013). Delayed small bowel transit in children with cystic fibrosis and pancreatic insufficiency. Journal of Pediatric Gastroenterology and Nutrition, 57(1), 81-84. https://doi.org/10.1097/MPG.0b013e318290d112

Rowland, S. J. (1938). 176. The Determination of the nitrogen distribution in milk. Journal of Dairy Research, 9(1), 42. https://doi.org/10.1017/S0022029900002296

Ryan, L., O’Connell, O., O’Sullivan, L., Aherne, S. A., \& O’Brien, N. M. (2008). Micellarisation of Carotenoids from Raw and Cooked Vegetables. Plant Foods for Human Nutrition, 63(3), 127-133. https://doi.org/10.1007/s11130-008-0081-0

Schieber, A., \& Carle, R. (2005). Occurrence of carotenoid cis-isomers in food: Technological, analytical, and nutritional implications. Trends in Food Science \& Technology, 16(9), 416-422. https://doi.org/10.1016/j.tifs.2005.03.018

Schlatterer, J., \& Breithaupt, D. E. (2006). Xanthophylls in commercial egg yolks: Quantification and identification by HPLC and LC-(APCI)MS using a C30 phase. Journal of Agricultural and Food Chemistry, 54(6), 2267-2273. https://doi.org/10.1021/jf053204d

Seuss-baum, I. (2007). Nutritional Evaluation of Egg Compounds. In R. Huopalahti, R. López-Fandiño, M. Anton, \& R. Schade (Eds.), Bioactive Egg Compounds (pp. 117-144). Berlin, Heidelberg: Springer Berlin Heidelberg. https://doi.org/10.1007/978-3-540-37885-3_18 
Shani-Levi, C., Alvito, P., Andrés, A., Assunção, R., Barberá, R., Blanquet-Diot, S., ... Lesmes, U. (2017). Extending in vitro digestion models to specific human populations: Perspectives, practical tools and bio-relevant information. Trends in Food Science \& Technology, 60, 52-63. https://doi.org/10.1016/j.tifs.2016.10.017

Sikkens, E. C. M., Cahen, D. L., Kuipers, E. J., \& Bruno, M. J. (2010). Pancreatic enzyme replacement therapy in chronic pancreatitis. Best Practice \& Research Clinical Gastroenterology, 24(3), 337-347. https://doi.org/10.1016/j.bpg.2010.03.006

Sponton, O. E., Perez, A. A., Carrara, C. R., \& Santiago, L. G. (2015). Linoleic acid binding properties of ovalbumin nanoparticles. Colloids and Surfaces B: Biointerfaces, 128, 219-226. https://doi.org/10.1016/j.colsurfb.2015.01.037

Sunwoo, H. H., \& Gujral, N. (2015). Chemical Composition of Eggs and Egg Products. In P. C. K. Cheung \& B. M. Mehta (Eds.), Handbook of Food Chemistry (pp. 331-363). Berlin, Heidelberg: Springer Berlin Heidelberg. https://doi.org/10.1007/9783-642-36605-5_28

Torcello-Gómez, A., Maldonado-Valderrama, J., De Vicente, J., CabrerizoVílchez, M. A., Gálvez-Ruiz, M. J., \& Martín-Rodríguez, A. (2011). Investigating the effect of surfactants on lipase interfacial behaviour in the presence of bile salts. Food Hydrocolloids, 25(4), 809-816. https://doi.org/10.1016/j.foodhyd.2010.09.007

Turck, D., Braegger, C. P., Colombo, C., Declercq, D., Morton, A., Pancheva, R., ... Wilschanski, M. (2016). ESPEN-ESPGHAN-ECFS guidelines on nutrition care for infants, children, and adults with cystic fi brosis. Clinical Nutrition, 35(3), 557-577. https://doi.org/10.1016/j.clnu.2016.03.004

Van Der Plancken, I., Van Loey, A., \& Hendrickx, M. E. (2006). Effect of heattreatment on the physico-chemical properties of egg white proteins: A kinetic study. Journal of Food Engineering, 75(3), 316-326. https://doi.org/10.1016/j.jfoodeng.2005.04.019

Vu, M. K., Vecht, J., Eddes, E. H., Biemond, I., Lamers, C. B., \& Masclee, a a. (2000). Antroduodenal motility in chronic pancreatitis: are abnormalities related to exocrine insufficiency? American Journal of Physiology. Gastrointestinal and Liver Physiology, 278, G458-G466. 
Weijers, M., Sagis, L. M., Veerman, C., Sperber, B., \& van der Linden, E. (2002). Rheology and structure of ovalbumin gels at low $\mathrm{pH}$ and low ionic strength. Food Hydrocolloids, 16(3), 269-276. https://doi.org/10.1016/S0268-005X(01)00097-2

Whitcomb, D. C., Lehman, G. a, Vasileva, G., Malecka-Panas, E., Gubergrits, N., Shen, Y., ... Caras, S. (2010). Pancrelipase Delayed-Release Capsules (CREON) for Exocrine Pancreatic Insufficiency due to Chronic Pancreatitis or Pancreatic Surgery: A Double-Blind Randomized Trial. The American Journal of Gastroenterology, 105(10), 2276-2286. https://doi.org/10.1038/ajg.2010.201 


\section{CHAPTER 2}

\section{INFLUENCE OF FOOD STRUCTURE AND GASTROINTESTINAL CONDITIONS ON FAT DIGESTIBILITY OF MEAT PRODUCTS}

In this second chapter, the study of digestibility moves onto meat products, identified as one of the main sources of dietary lipids in children suffering from $\mathrm{CF}$ and pancreatic insufficiency in Mycyfapp context. For this reason, a suite of 9 meat products were included as representatives of different matrix structures: raw meat products, preserving the native structure of protein fibres entrapping fat; and processed meat products undertaking mincing or emulsification as part of the industrial processing, resulting in restructured or emulsified products. Depending on the industrial processing, meat products can be directly consumed (such as ham, luncheon meats or pate) or require cooking (fresh pieces, such as pork loin, beef steak or chicken drumstick). Processed meats are the preferred choice over the fresh varieties due to its cost and time of preparation. Meat is an important source of proteins, vitamins and in most of the cases contains lipids. Depending of the cut and the animal origin, the amount of protein and lipids can vary. Furthermore, cooking and processing also affect the final structure. As protein digestibility in meat is a well-documented phenomenon, the study of proteolysis was not contemplated in this research. Rather, it was focused on characterising lipolysis and its possible association with the food matrix structure and its degradation during the digestion process.

In the present study, lipid digestibility of different meat products was evaluated by means of static in vitro gastrointestinal digestion including different intestinal scenarios (healthy and CF). After intestinal digestion, samples were centrifugated and filtrated to separate two fractions: liquid fraction considered as the bioaccessible fraction where free fatty acids are present, and solid fraction. Matrix degradation was determined in the solid fractions, while lipolysis was analysed in the bioaccessible fraction by means of a spectrophotometry enzymatic kit. Lipolysis was expressed such as mg of FFA release per gram of lipid. 
The results revealed that, lipolysis extents in meat products digested under intestinal scenario of $\mathrm{CF}$ were significantly lower than their counterparts digested under standard healthy conditions. Besides, the effect of the intestinal conditions on lipid digestibility varied according to the meat product. Thus, some of the assessed foods showed to be more dependent on the bile salts concentration in the digestion medium than others, in which this variable seemed not to have an impact on lipolysis. This finding was attributed to the role of the types of proteins present in some of the meat products, which could have had a similar role than bile salts in emulsifying fat in the digestion medium, facilitating lipolysis. Regarding the effect of the matrix structure (native or unstructured) had a significant impact on matrix degradation index, the processed meat products resulting in unstructured matrices being more successfully degraded during digestion. In turn, and this representing the main finding of the study, the matrix degradation index achieved was positively correlated with the extent of lipolysis, so those products with higher degradation index reached higher lipolysis extent. In this regard, and in the $\mathrm{CF}$ intestinal conditions, hamburger, sausage, pate and luncheon meat reached FFA release between 400 and $500 \mathrm{mg} / \mathrm{g}$ lipid; while in beef steak, chicken drumstick, pork loin, cooked ham or cured ham, it ranged from 100 to $350 \mathrm{mg} \mathrm{FFA/g}$ lipid approximately.

Finally, the effect of the pancreatin concentration in the digestion medium was assessed to comply with the ultimate goal of establishing the optimal recommended dose of enzymatic supplements for patients with CF and pancreatic insufficiency. In both series of foods, a general increase in lipolysis was experimented when increasing the pancreatin concentration from 1000 to $2000 \mathrm{LU} / \mathrm{g}$ fat and in some cases, to $3000 \mathrm{LU} / \mathrm{g}$ fat. However, higher concentrations did not significantly increase lipolysis extents, which in turn was decreased in some particular cases, probably due to enzyme aggregation. Regarding optimal enzyme concentration to maximise lipolysis under CF conditions in products presenting a native structure, results showed that beef steak, chicken drumstick, and pork loin obtained the maximum value of lipolysis (405, 403, and $320 \mathrm{mg} / \mathrm{g}$ respectively) at enzyme concentration of $3000 \mathrm{LU} / \mathrm{g}$ lipid. In case of ham, cooked ham achieved a lipolysis of $580 \mathrm{mg} / \mathrm{g}$ at $1000 \mathrm{LU} / \mathrm{g}$ lipid, while cured ham 
obtained a maxim lipolysis $(344 \mathrm{mg} / \mathrm{g}$ ) at $2000 \mathrm{LU} / \mathrm{g}$ lipid. In case of unstructured products, the optimal pancreatin concentration to maximise lipolysis (hamburger 429 $\mathrm{mg} / \mathrm{g}$, luncheon meat $500 \mathrm{mg} / \mathrm{g}$, pate $613 \mathrm{mg} / \mathrm{g}$, and sausage $525 \mathrm{mg} / \mathrm{g}$ ) was reached at dose of $2000 \mathrm{LU} / \mathrm{g}$ lipid.

Therefore, two practical recommendations can be extracted from this research when aiming at improving lipid digestion in CF patients: 1) unstructured meat products should be preferred, as they are more easily disintegrated during digestion and the lipids they contain are more accessible to digestive enzymes; and 2) a dose of $2000 \mathrm{LU} / \mathrm{g}$ fat of the pancreatic enzyme supplements used in the treatment of pancreatic insufficiency should be applied when consuming meat products, except in some concrete cases in which the dose of $3000 \mathrm{LU} / \mathrm{g}$ fat should be used. 


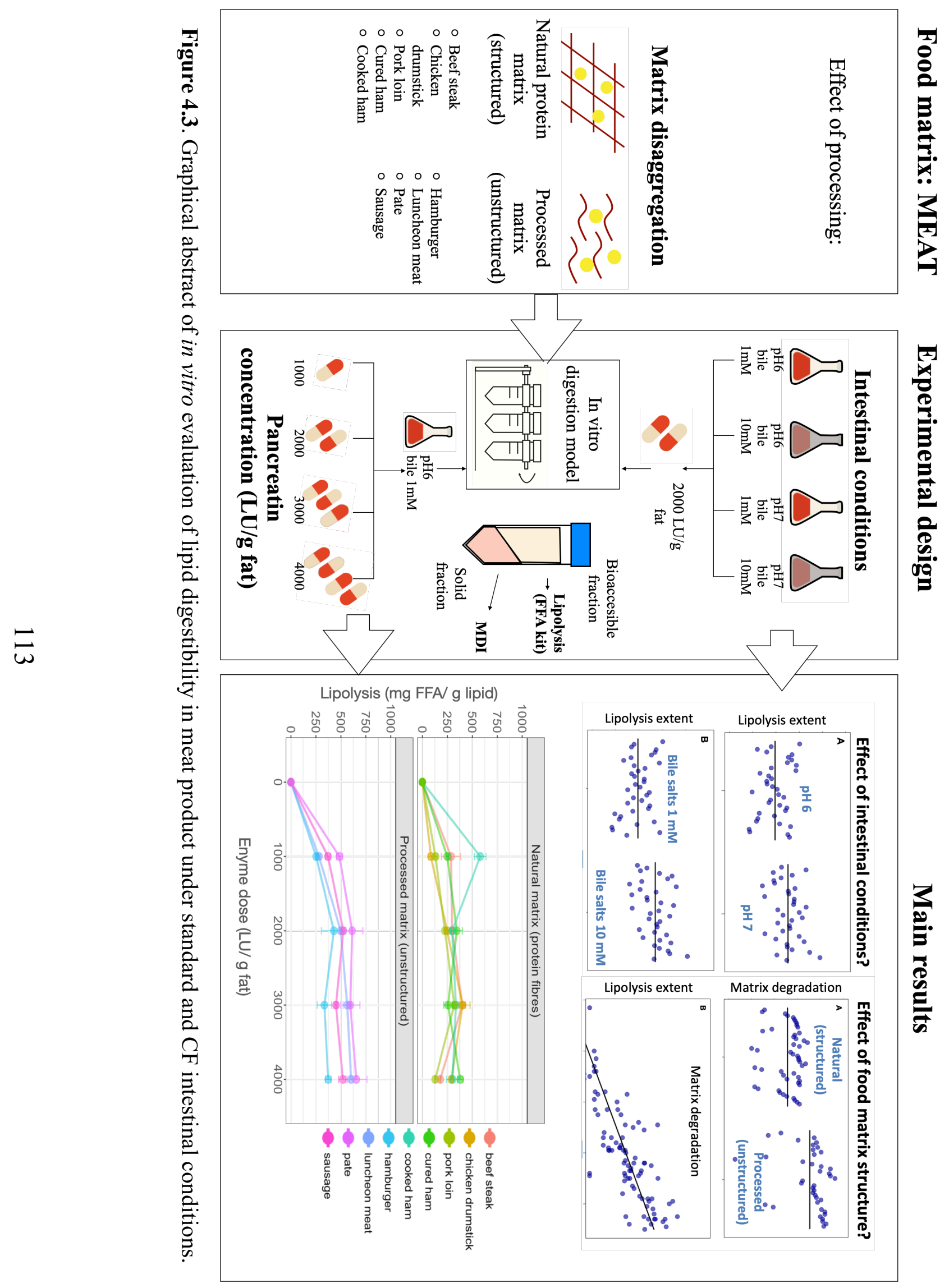


Title: Fat digestibility in meat products: influence of food structure and gastrointestinal conditions

Andrea Asensio-Grau, Joaquim Calvo-Lerma, Ana Heredia and Ana Andrés

International Journal of Food Sciences and Nutrition, 530-539.

https://doi.org/10.1080/09637486.2018.1542665

\begin{abstract}
Digestibility of macronutrients depends on the food matrix structure as well as on gastrointestinal conditions, especially in patients with exocrine pancreatic insufficiency. In this situation, an oral enzyme supplementation that promotes nutrient hydrolysis is needed. In this context, in the present study, a static in vitro digestion model was used to assess the lipid digestibility of different meat products (processed and fresh), different intestinal conditions of $\mathrm{pH}$ ( 6 or 7$)$, bile concentration ( 1 or $10 \mathrm{mM})$, and doses of the enzyme supplement (1000 to 4000 lipase units/ g fat). Results showed that processed (unstructured) meats had better matrix degradation during digestion and reached higher values of lipolysis extents (total free fatty acids/ $g$ fat) than the natural meat matrices with a statistically significant association $(\mathrm{p}<0.001)$. Regarding the intestinal medium, $\mathrm{pH}$ of 7 and bile concentration of $10 \mathrm{mM}$ contribute to higher matrix degradation, and thus, to a higher lipolysis $(\mathrm{p}<0.001)$.
\end{abstract}

Keywords: in vitro digestion, lipolysis, nutrition, pancreatic insufficiency, food matrix 


\section{INTRODUCTION}

Nowadays meat products are overconsumed in the western societies, both in young and adult populations, and the consumption exceeds the recommended daily intake (Huybrechts et al, 2010, Moreira et al, 2010, Pérez-Rodrigo et al. 2015, Roccaldo et al. 2014). Processed meats are the preferred choice over the fresh varieties because processed meat products are cheaper and easier to prepare. Moreover, the fast-food type restaurants, which offer mainly the varieties of meat that are already prepared and processed, are a frequent meal choice (Bhutani, Schoeller et al. 2018, Close et al. 2016, French et al. 2001).

Meat is an important source of protein and vitamins and its composition also contains fat and water (Pereira and Vicente 2013). Different meats and cuts are composed of distinctive types of muscle fibres and they contain varying amounts of connective tissues. This implies that the quality and structure of them are very diverse (Greenfield et al. 2009). In addition, the processing method of meat, as well as including the cooking technique, may also affect the final structure resulting in a wide variety of food matrices in this food group (Bax et al. 2012, Luo et al. 2018). Concerning the fat fraction and quality of the meat, they depend on the area of the meat portion as well as the origin of the animal.

While several studies assessing proteolysis in meat products have been published in the recent years, scarce literature is available regarding the study of lipolysis. Given the direct effect of dietary fat intake on the development of diet-based diseases (de Souza et al. 2015), it is important to unveil the digestion fate of this nutrient when it comes from a food choice as popular as meat.

Processed meats normally have a higher fat content than non-processed varieties, as they are made of the animal parts that are less consumed, have less sensory quality and a lower consumer acceptance. However, apart from the fat content, the structure also could influence digestibility of this nutrient. Concretely, in natural structure of meat, fat molecules are embedded in muscle fibres while processed meats have an unstructured mixture of fat, protein and water, and in some cases, carbohydrates are also added (Guo 
et al. 2017). Therefore, in order to address the study of lipid digestibility in meat, the influence of the meat structure should be taken into account.

Lipid digestion is a complex process, which takes place in the duodenal region of the small intestine, which implies a previous micellization in order to provide the enzyme access allowing lipid hydrolysis. During this process, the intestinal $\mathrm{pH}$ and the presence of bile salts are crucial to improve the enzymatic hydrolysis (Ryan et al. 2008, Whitcomb et al. 2010). The intestinal $\mathrm{pH}$ is directly related to the enzyme activity and efficiency. Moreover, the bile salts act as emulsifying agents leading to the micellization of fat and providing a larger surface area on the fat globule for the enzyme to adsorb. However, the alteration of these factors could compromise the lipid digestibility in some individuals who suffer from exocrine pancreatic insufficiency (EPI), mainly present in patients with Cystic Fibrosis. The obstruction of the pancreatic duct in EPI produces an insufficient secretion of pancreatic juice, which contains the digestive enzymes. Moreover, the secretion of sodium bicarbonate $\left(\mathrm{NaHCO}_{3}\right)$ is also reduced, causing a drop in the intestinal $\mathrm{pH}$ and the consequent reduction of the pancreatic enzymes activity. This situation leads to the mal-digestion and mal-absorption of nutrients (Layer and Keller 2003, Naikwade et al. 2009). The treatment for EPI consists in oral administration of pancreatic enzyme supplements, containing proteases and mainly lipase (Armand et al. 2011). The current guidelines for nutritional management in Cystic Fibrosis recommend a dose of the enzymatic supplement of $2000-4000 \mathrm{LU} / \mathrm{g}$ fat, with a very low degree of evidence (Turck et al. 2016). The modulation of both intestinal $\mathrm{pH}$ and bile salts concentration in the intestinal digestion medium are thus of upmost relevance in the process of lipolysis.

In vitro studies are a useful tool that allows studying the structural changes, the digestibility and release of food components under simulated gastrointestinal conditions. In this context, the goal of the present study was to evaluate the influence of gastrointestinal conditions associated with EPI (intestinal $\mathrm{pH}$, bile salts concentration and the dose of the enzyme supplement) as well as the effect of the food matrix on lipid digestibility in different meat products. 


\section{MATERIALS AND METHODS}

\subsection{Materials}

The different meat products (hamburger (just the meat patty, 100\% minced pork meat), sausage, luncheon ham, cooked ham, cured ham, pate, chicken drum, pork loin and beef steak were obtained from a local supermarket in Valencia (Spain).

For the preparation of the simulated digestive fluids (Table 4.6) the following chemicals were needed: human $\alpha$-amylase (1000 - $3000 \mathrm{U} / \mathrm{mg}$ protein) (CAS: 9001-19-8), pepsin from porcine gastric mucosa ( $\geq 2500 \mathrm{U} / \mathrm{g}$ protein) (CAS: 9001-75-6), bovine bile extract (CAS: 8008-63-7), $\mathrm{KCl}, \mathrm{KH}_{2} \mathrm{PO}_{4}, \mathrm{NaHCO}_{3}, \mathrm{NaCl}, \mathrm{MgCl}_{2}(\mathrm{H} 2 \mathrm{O})_{6},\left(\mathrm{NH}_{4}\right)_{2} \mathrm{CO}_{3}$ and $\mathrm{CaCl}_{2}$, all of them from Sigma-Aldrich Chemical Company (St Louis, MO, USA). $\mathrm{NaOH}(1 \mathrm{~N})$ and $\mathrm{HCl}(1 \mathrm{~N})$, were all acquired from AppliChem Panreac. Pancreatic enzymes supplements (Kreon 10,000 lipase units (LU)) were used to simulate in vitro digestion of an individual with EPI. Each capsule contains $150 \mathrm{mg}$ of gastro-resistant microspheres containing porcine pancreatic enzyme equivalent to 10,000 lipase U., 8,000 amylase U., and 600 protease U. The specific lipase activity of the Kreon was usually measured before the experiments (Carriere et al. 2000) and the amount of supplement added to the gastric stage was adjusted always to have the corresponding $\mathrm{LU} / \mathrm{g}$ fat according to the experimental design.

For the analytical determinations, Triton-X $100 \%$, as well as the analytical standard of palmitic acid, were acquired from Sigma-Aldrich. Ethanol (96 \% v/v for analysis) was acquired from AppliChem Panreac. 
Table 4.6. Composition of simulated digestion fluids.

\begin{tabular}{cccc}
\hline Constituent & $\begin{array}{c}\text { SSF } \\
\text { mmol/ }\end{array}$ & $\begin{array}{c}\text { SGF } \\
\text { mmol/ L }\end{array}$ & $\begin{array}{c}\text { SIF } \\
\mathrm{mmol} / \mathrm{L}\end{array}$ \\
\hline $\mathrm{KCl}$ & 15.1 & 6.9 & 6.8 \\
$\mathrm{KH}_{2} \mathrm{PO}_{4}$ & 3.7 & 0.9 & 0.8 \\
$\mathrm{NaHCO}_{3}$ & 13.6 & 25 & 85 \\
$\mathrm{NaCl}$ & - & 47.2 & 38.4 \\
$\mathrm{MgCl}_{2}\left(\mathrm{H}_{2} \mathrm{O}\right)_{6}$ & 0.15 & 0.1 & 0.33 \\
$\left(\mathrm{NH}_{4}\right)_{2} \mathrm{CO}_{3}$ & 0.06 & 0.5 & - \\
$\mathrm{CaCl}_{2}$ & 1.5 & 0.15 & 0.6 \\
\hline
\end{tabular}

The addition of pepsin, $\mathrm{Ca}^{2+}$ solution and water will result in the correct electrolyte concentration in the final digestion mixture.

SSF: Simulated Salival Fluid; SGF: Simulated Gastric Fluid; SIF: Simulated Intestinal Fluid.

\subsection{Sample preparation}

Prior to the digestion process, hamburger, chicken drum, pork loin and beef steak were placed in a microwavable plate and cooked in a household microwave oven (model GW72N, Samsung) for $4 \mathrm{~min}$ at $600 \mathrm{~W}, 2450 \mathrm{MHz}$. For the rest of the matrices (luncheon ham, pate, cured ham, cooked ham and sausage) a thermic treatment was not necessary because they were ready to eat. After their preparation, all samples were in vitro digested by using a static system.

\subsection{In vitro digestion process}

Meat samples were placed into falcon tubes $(50 \mathrm{ml})$; the amount of samples to be digested was weighted in order to have $0.35 \mathrm{~g}$ of fat in each tube. Fat, water and protein content in all meat products was determined before digestion by the official methods (AOAO, 2000).

The digestion proceeding used was based on the standardized static in vitro digestion method for food published by Minekus et al. (2014) with some modifications in order to allow for analysing EPI conditions. Table 4.6 illustrates the amounts and composition of the fluids required in each of the stages of the digestion process (Minekus et al. 2014). The digestion fluids were prepared daily from stock solutions, salivary 
(SSS), gastric (SGS) and intestinal (SIS) prepared according to Minekus et al. (2014). The enzymatic activity was tested before each simulation following the protocol proposed by Carriere et al., (2000). The in vitro digestion process was performed as follows:

Oral stage: Simulated salivary fluid $(5 \mathrm{ml})(\mathrm{SSF} ; \mathrm{pH} 8)$ at $37^{\circ} \mathrm{C}$, was added to the meat sample in a 1:1 (w/v) ratio and properly homogenized with a kitchen blender for 3 minutes (Vario Mixer, Ufesa $600 \mathrm{~W}$ ). Salivary amylase was added into SSF to reach a concentration in the saliva mixture of $75 \mathrm{U} / \mathrm{ml}$.

Gastric stage: After the oral stage, simulated gastric fluid (SGF; pH 3) was added to each tube containing the oral bolus $(1: 1 \mathrm{v} / \mathrm{v})$. Pepsin was added into the SGF to reach a concentration in the gastric mixture of $2000 \mathrm{U} / \mathrm{ml}$. The $\mathrm{pH}$ of the mixtures was adjusted with $\mathrm{HCl}(1 \mathrm{~N})$ to $\mathrm{pH} 2.8 \pm 0.1$ and samples were flipped from top to bottom at $55 \mathrm{rpm}$ for 2 hours using an Intell-Mixer RM-2 (Elmi Ltd, Riga, LV-1006, Latvia) and incubated at $37^{\circ} \mathrm{C}$ in a chamber Selecta (JP Selecta SA, Barcelona). These mixing conditions provided constant mechanical energy to induce the breakdown of the food matrix during digestion. The pancreatic supplement was added in the gastric stage in order to simulate swallowing the pill in case of EPI situations.

Intestinal stage: Following the gastric stage, simulated intestinal fluid (SIF; pH 7) was added in a $1: 1(\mathrm{v} / \mathrm{v})$ proportion to each tube containing the gastric chime. The $\mathrm{pH}$ of the mixtures was adjusted to $\mathrm{pH} 6.0 \pm 0.1$ or $7.0 \pm 0.1$, depending on the conditions to be tested, with $\mathrm{NaOH}(1 \mathrm{~N})$. Samples were then being agitated from top to bottom at 55 rpm for another 2 hours at $37^{\circ} \mathrm{C}$. $\mathrm{pH}$ was monitored during the digestion process and readjusted if necessary to keep it constant (González-Bacerio et al. 2010, Prazeres et al. 1994).

\subsection{Experimental design}

The experimental design for each type of product (hamburger, sausage, luncheon ham, cooked ham, cured ham, pate, chicken drum, pork loin and beef steak) consisted of two main sets of experiments. In the first, intestinal conditions were fixed at pH 6 and bile salts concentration $1 \mathrm{mM}$, and different pancreatin supplement doses $(0,1000,2000$, 
3000 and $4000 \mathrm{LU} / \mathrm{g}$ of lipid) were tested, in order to assess the influence of enzyme concentration. In the second, the dose of enzymes was fixed at $2000 \mathrm{LU} / \mathrm{g}$ of lipid, and the study variables were different combinations of intestinal $\mathrm{pH}$ and bile concentration: pH6-1 mM, pH 6-10 mM, pH 7-1 mM and pH 7-10 mM, in order to analyse the impact of different intestinal scenarios on lipolysis, and matrix degradation. Of note, the combination $\mathrm{pH} 6-1 \mathrm{mM}$ would represent the most unfavourable condition in the gastrointestinal tract in EPI (Clarke 2001, Gelfond et al. 2013, Harries et al. 1979, Rovner et al. 2013, Vu et al. 2000), and the $\mathrm{pH} 7-10 \mathrm{mM}$ would approach the standard duodenal conditions of a healthy adult. All the experiments were conducted in triplicate.

\subsection{Analytical determinations}

\subsubsection{Matrix Degradation Index (MDI (\%))}

Matrix Degradation Index (MDI) was determined in all samples after in vitro digestion. This parameter represents the proportion of solids that were finely dispersed in the final product of digestion. The total content of a digestion tube was centrifuged (4000 x g for 20 minutes, $4^{\circ} \mathrm{C}$ ) and filtered by a metallic sieve (1.6 $\mathrm{mm} \times 1.6 \mathrm{~mm}$ mesh) to separate out large particles. The drained liquid was collected and used to determine the free fatty acids. The solid particles were rinsed twice with $5 \mathrm{ml}$ of appropriate juice to remove any digested material. Blotting paper was placed around the metallic sieve for 10 minutes to drain residual digestion juice. The solid meat particles were then transferred to an aluminum dish and immediately weighed. The aluminum dish was put in a forced air oven at $60{ }^{\circ} \mathrm{C}$ for 48 hours and weighed again to determine the mass of large solids. The MDI, corresponding to the proportion of solids passing the metallic sieve, was calculated according to Lamothe et al. $(2012,2014)$.

\subsubsection{Lipolysis extent (\%)}

Drained juice from digested samples was diluted 100 -fold with a solution made of 5.6\% Triton X-100 and 6\% ethanol in water (Lamothe et al. 2012) . This solution was used to solubilize the free fatty acids (FFA) and stop the lipase activity. Fatty acids release during digestion was measured on the diluted samples using a free fatty acid colorimetric assay kit (Roche Diagnostics, Indianapolis, IN, USA) and a 
spectrophotometer (UV/vis, Beckman Coulter) (Lamothe et al. 2014). Palmitic acid standard was used for quantitative determination of FFA. Total FFA was expressed as $\mathrm{mg}$ of fatty acids released after a complete digestion per gram of initial fat present in each meat product.

\subsection{Statistical analysis}

The variables included for the statistical analysis were the nutrient composition of foods: water, protein and fat, starch; and the food matrix structure: natural food matrix (protein fibres) or processed matrix (unstructured); the pancreatic enzyme supplement concentration (enzyme dose); the intestinal conditions: $\mathrm{pH}$ and bile salts concentration; and the matrix degradation index (MDI). The response variables were lipolysis extent (total FFA) and the MDI.

Data were summarised using mean, standard deviation, median and $1^{\text {st }}$ and $3^{\text {rd }}$ quartile in the case of continuous variables and with absolute ant relative frequencies in the case of categorical variables.

Linear mixed regression models were performed to assess the effect of the food matrix structure and other factors such as matrix degradation index were included as covariates. Additionally, because observations of the same food are more likely to have similar lipolysis extent due to their nutritional characteristics, the linear regression models were extended with the "Food" variable as random effect with random intercept to correct for the non-independence of the data.

All the analyses were performed by software R (version 3.4.2) using packages betareg (version 3.1-0), lme4 (version 1.1-14) and NMF (version 0.20.6). A p-value lower than 0.05 was considered statistically significant.

\section{RESULTS AND DISCUSSION}

\subsection{Effect of the food structure on matrix degradation and fat digestibility}

The degradation of the food matrix is the process by which the 3D structural conformation of a food is disrupted into smaller parts allowing for the release of the structural components, i.e. the nutrients (Table 4.7). It is facilitated by several 
mechanisms: mainly the mechanical forces produced along the gastrointestinal tract (chewing in the mouth, stomach walls agitation and small intestine peristaltic movements) and the enzymatic activity that contributes to the breakdown of nutrients conforming the matrix structure. Thus, when no enzymes were used in the in vitro digestion, significantly lower matrix degradation indexes were obtained (Figure 4.4) as compared to digestions conducted with pancreatic enzyme supplements. Generally, the enzymatic supplements increase of $1000 \mathrm{LU} / \mathrm{g}$ of fat led to a minor increase in the MDI. In the case of the natural matrices (protein fibres) maximum MDI were between 50 and $75 \%$, while in the unstructured matrices higher degradation extents were reached $(>75 \%)$.

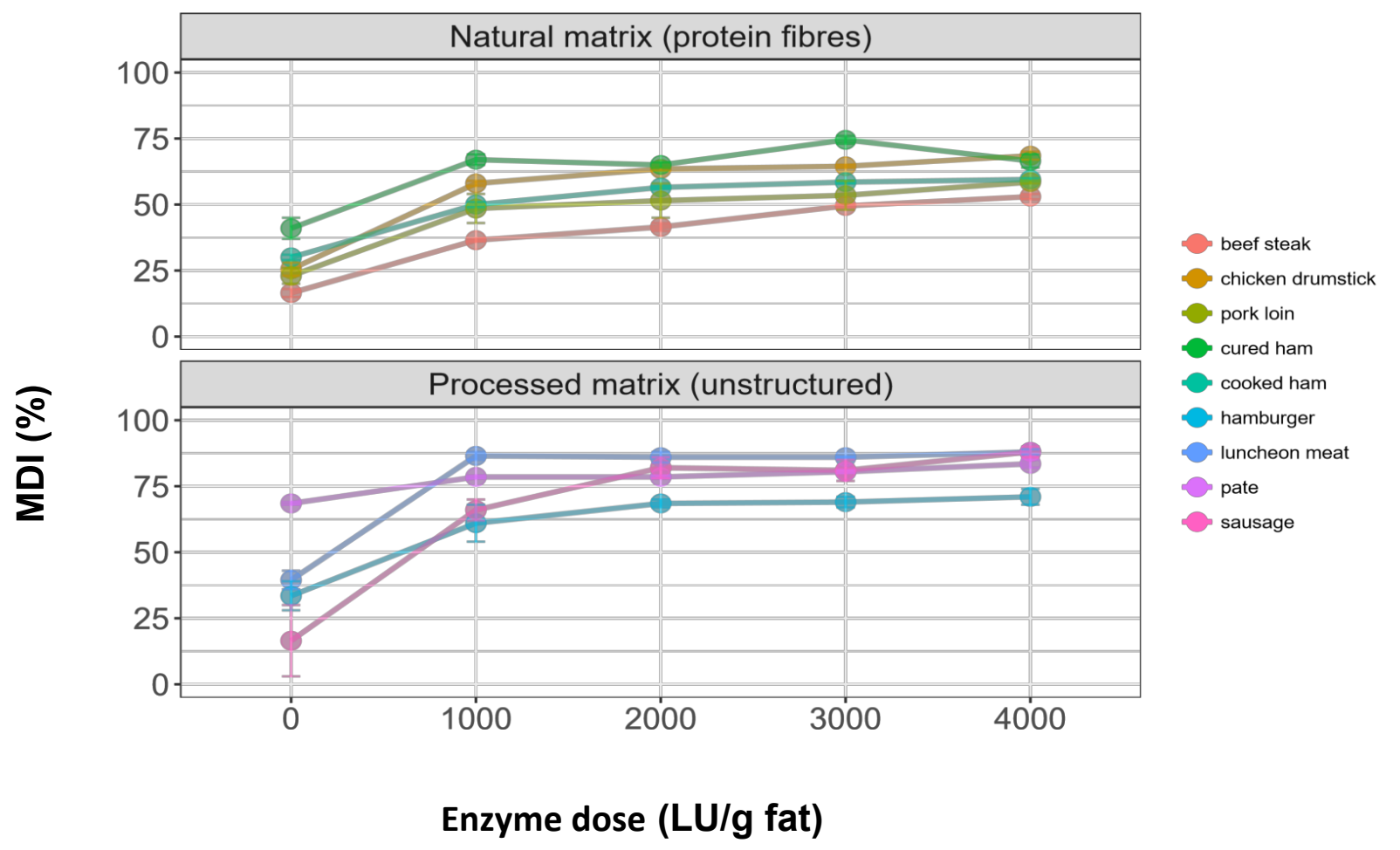

Figure 4.4. Matrix degradation index (MDI, \%) of the meat products after in vitro digestion with five pancreatic enzyme supplements concentrations (enzyme dose, LU/g fat), classified according to the food matrix structure. 
Table 4.7. Characterization of water, fat and protein content in the different meat matrices expressed as $\mathrm{g} / \mathrm{g}$ of product.

\begin{tabular}{cccc}
\hline Meat product & $\begin{array}{c}\text { Water content } \\
(\mathbf{g} / \mathbf{g} \text { product })\end{array}$ & $\begin{array}{c}\text { Fat content } \\
(\mathbf{g} / \mathbf{g} \text { product })\end{array}$ & $\begin{array}{c}\text { Protein content } \\
(\mathbf{g} / \mathbf{g} \text { product })\end{array}$ \\
\hline Hamburger & $0.51 \pm 0.03$ & $0.24 \pm 0.04$ & $0.21 \pm 0.02$ \\
Sausage & $0.683 \pm 0.002$ & $0.107 \pm 0.003$ & $0.18 \pm 0.02$ \\
Luncheon ham & $0.653 \pm 0.002$ & $0.120 \pm 0.006$ & $0.11 \pm 0.003$ \\
Pate & $0.606 \pm 0.004$ & $0.30 \pm 0.09$ & $0.090 \pm 0.002$ \\
Cured ham & $0.529 \pm 0.03$ & $0.1 \pm 0.02$ & $0.32 \pm 0.05$ \\
Cooked ham & $0.756 \pm 0.004$ & $0.025 \pm 0.03$ & $0.199 \pm 0.006$ \\
Chicken drum & $0.649 \pm 0.012$ & $0.12 \pm 0.03$ & $0.201 \pm 0.004$ \\
Pork loin & $0.543 \pm 0.026$ & $0.135 \pm 0.06$ & $0.29 \pm 0.04$ \\
Beef steak & $0.56 \pm 0.014$ & $0.10 \pm 0.03$ & $0.30 \pm 0.03$ \\
\hline
\end{tabular}

In terms of fat digestibility (total release of FFA), a similar tendency as in the MDI was shown for all the assessed meat products (Figure 4.5). In those matrices which preserve the protein fibres structure, the total FFA increased with the concentration of the enzymatic supplement up to $3000 \mathrm{LU} / \mathrm{g}$ fat, and it slightly decreased at $4000 \mathrm{LU} / \mathrm{g}$ fat, probably due to inactivation by aggregation. It has been described that when a high concentration of enzymes is not active in the reaction medium (e.g. because there is no substrate available) aggregation and inactivation occur. Furthermore, the release of fat particles from the protein fibres complex is a progressive and slow process, so this may lead to a low concentration of substrate at the beginning of the digestion. This may be the reason of the inactivation phenomenon (López-Gallego et al. 2005). In contrast, in unstructured matrices, the release of FFA was directly proportional to the concentration of enzymes. Pate and luncheon meat reached a total FFA released close to $600 \mathrm{mg} / \mathrm{g}$ fat at enzyme dose of $4000 \mathrm{LU} / \mathrm{g}$ fat. On the other hand, hamburger and sausage reached a lipolysis extent of 500 and $300 \mathrm{mg}$ FFA/ g fat, respectively. In any case, the highest value of lipolysis was reached at enzyme dose of $3000 \mathrm{LU} / \mathrm{g}$ fat. 


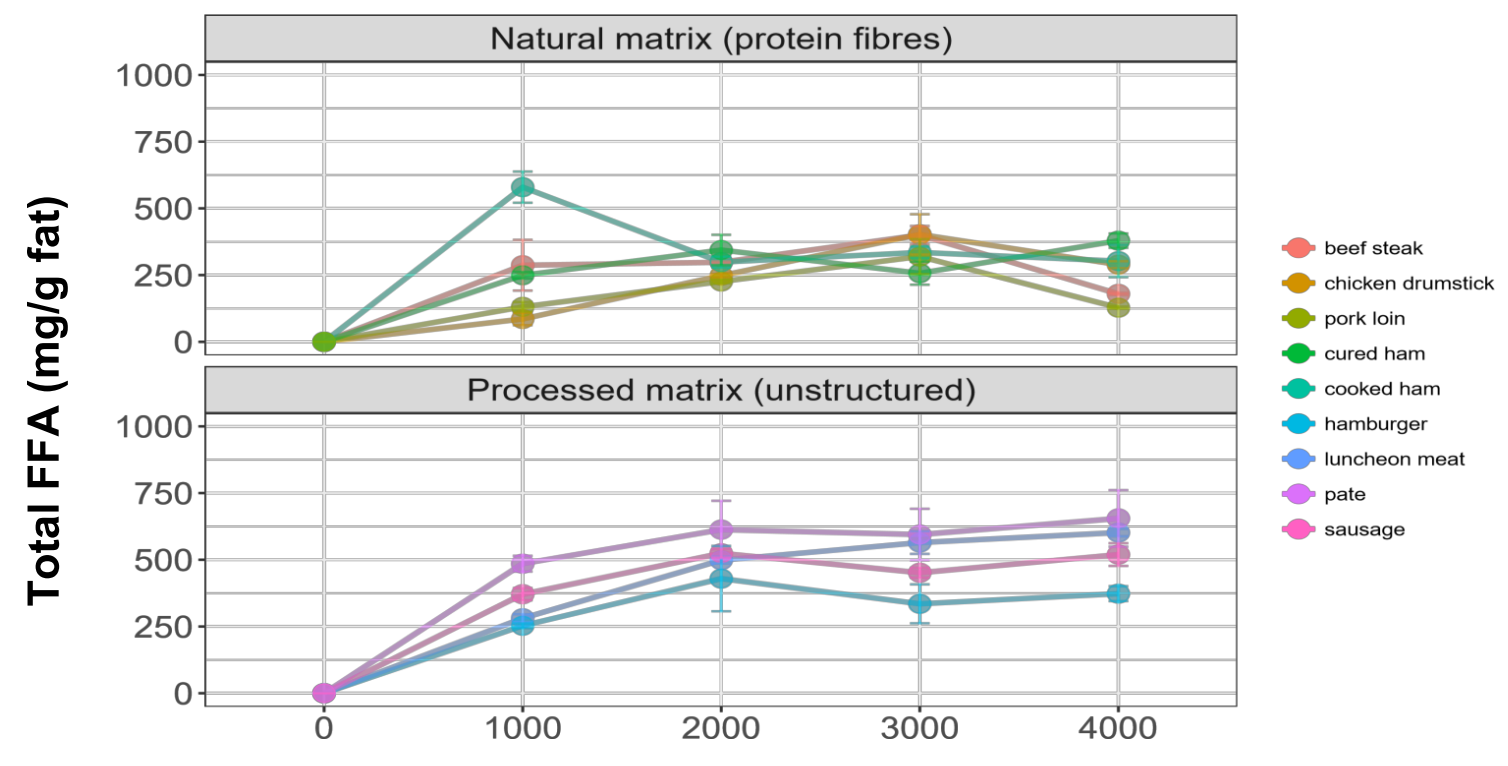

Enzyme dose (LU/g fat)

Figure 4.5. Lipolysis extent (total FFA, $\mathrm{mg} / \mathrm{g}$ fat) of the meat products after in vitro digestion with five pancreatic enzyme supplements concentrations (enzyme dose, LU/g fat), classified according to the food matrix structure.

The fact that MDI and total FFA released followed the same tendency was, indeed, statistically explained, finding significant associations between the type of matrix and the MDI, and between the MDI and the fat digestibility (Figure 4.6). The unstructured matrices allowed for higher MDI than the natural protein fibres, up to $30.6 \%$ more $(\mathrm{p}=$ $0.013,95 \%$ CI $[8.148,30.612])$; and the higher MDI were associated with higher total FFA released, every 1\% increase produced between 6.1 and $9.6 \mathrm{mg}$ of FFA more (p $<0.001,95 \%$ CI $[6.128,9.606])$.

These relationships are backed up by previous literature providing a physical explanation, as previously compiled by Guo et al. (2017). When fat molecules are trapped in a solid food matrix, the structure of the surrounding food matrix is the dominant factor controlling digestion. In order to make lipids available to the enzymes, the degradation of the protein food matrix has to occur. In such systems, lipolysis is thus conditioned by the rate and extent of proteolysis: as the protein structure is broken down, 
the lipids are released from the matrix, and lipases can start hydrolysis (Dickinson 2012).

An example of this type of system was described by Dickinson (2012), in which protein gels containing lipids were formulated with different amounts of protein and forming different microstructures (hard and soft gels). The soft gel presented an in vitro digestion behaviour similar to a liquid whey protein emulsion, but the hard gel showed slower lipolysis rates and extents, as the gel structure was degraded along digestion and allowed for fat droplets release from the matrix (Guo et al. 2017, Guo et al. 2016).

Another example supporting our findings is the study of fat digestibility in chewed almonds versus their isolated fat molecules, which lipolysis extents were 22 and $69 \%$ after one hour of in vitro digestion (Grundy et al. 2017). The study pointed at the fact that cells remained largely intact after mastication and concluded that lipid bioaccessibility in almonds was dependent on the structure and the cell walls surrounding the oil droplets.

Finally, the role of the food structure in protein-lipid matrices has been also assessed in two types of cheese (Fang et al. 2016). Cheddar cheese had larger fat globules that made the structure less hard and more easily degraded. On the other hand, the mozzarella had a denser fibrous protein matrix. In terms of digestibility, it was higher in cheddar as fat globules were rapidly released and accessible to the enzymes, while in mozzarella the fibrous structure prevented fat release and thus led to a lower lipolysis extent.

In the present study, natural protein fibres matrix represents a robust structure in which lipids are contained, and the unstructured matrices suppose a softer system in which lipid and protein are not bonded or linked to each other. This structural fact explains why the unstructured matrices had more MDI and consecutively a higher amount of FFA release.

Apart from the food structure, the conditions of the digestive fluid and the intestinal environment may also affect the behaviour of food digestion. These are explored and explained in the coming section. 


\subsection{Effect of the intestinal conditions on matrix degradation and fat digestibility}

In all the assessed intestinal conditions, the unstructured matrix meat products had higher MDI than the structured, values ranging from 69 to $78.6 \%$ and 42 to $70 \%$, respectively (Table 4.8). The intestinal $\mathrm{pH}$ had a significant effect on the matrix degradation index, as in all the assessed meat products it allowed for an increase between 5 and $15 \%(p<0.01)$. However, when comparing the effect of the bile salts concentration at intestinal $\mathrm{pH} 6$ or at $\mathrm{pH} 7$, this showed a non-significant increase in the matrix degradation index. Pate was an exception, in which MDI increased 7\% at the $10 \mathrm{mM}$ concentration, both in $\mathrm{pH} 6$ and 7. In contrast, the role of bile was not significant in proteolysis, but it was important on lipolysis due to the bile emulsify the lipids allowing a higher surface area available for the lipases action.
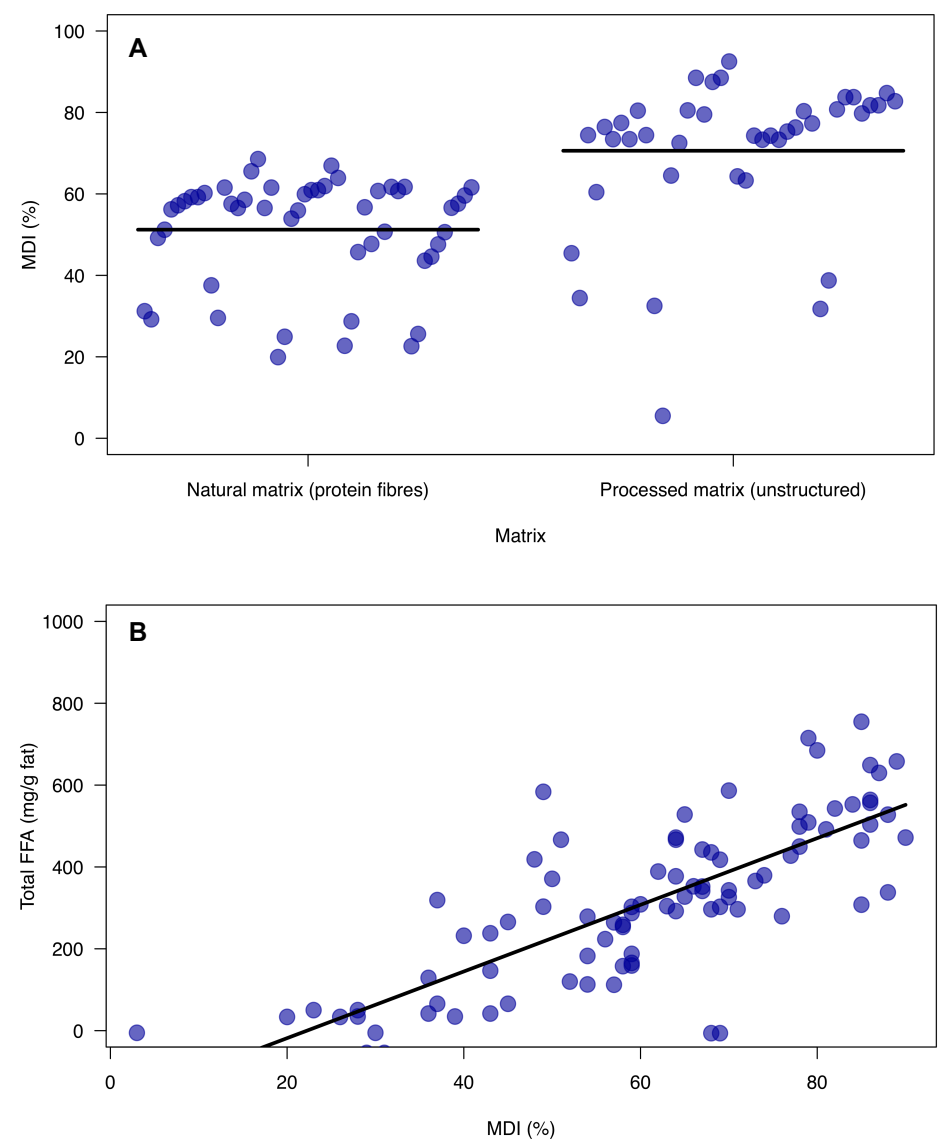

Figure 4.6. Linear mixed regression model plot. (A) Effect of the food matrix (natural or processed) on matrix degradation index (MDI): processed matrices have significantly higher MDI $(p=0.013,95 \%$ CI $[8.148,30.612])$. (B) Effect of the MDI on the total FFA released: the higher the MDI, the higher the total FFA released ( $p<0.001$, 95\% CI $[6.128,9.606])$. 
Overall, in terms of fat digestibility, the release of total FFA was significantly higher at $\mathrm{pH} 7$ ( $\mathrm{p}<0.001,95 \%$ CI $[53.5,168.9])$ and at bile salts concentration of $10 \mathrm{mM}$ ( $\mathrm{p}<0.001,95 \%$ CI $[90.2,205.6])$ (Figure 4.7). The 95\% CI represent the extent to which the $\mathrm{pH} 7$ and bile $10 \mathrm{mM}$ conditions produce an increase in the total FFA. This is in accordance to previous studies conducted by our group (Asensio-Grau et al. 2018, Peinado et al. 2018).

Table 4.8. Matrix Degradation Index (\%) obtained for the different meat matrices (hamburger, sausage, luncheon ham, pate, cured ham, cooked ham, chicken drum, pork loin and beef steak) after the in vitro digestion process using a fixed enzyme dose $(2000 \mathrm{LU} / \mathrm{g}$ fat $)$ and different duodenal conditions of $\mathrm{pH}$ and Bile concentration.

\begin{tabular}{|c|c|c|c|c|c|c|c|c|}
\hline & \multicolumn{2}{|c|}{ pH 6 - 1 mM } & \multicolumn{2}{|c|}{ pH 6-10 mM } & \multicolumn{2}{|c|}{ pH $7-1 \mathrm{mM}$} & \multicolumn{2}{|c|}{ pH $7-10 \mathrm{mM}$} \\
\hline \multicolumn{9}{|l|}{ MDI (\%) } \\
\hline Hamburger & 69 & \pm 2 & 69.06 & \pm 1.12 & 83 & \pm 4 & 82.1 & \pm 0.9 \\
\hline Sausage & 82 & \pm 6 & 79 & \pm 3 & 94 & \pm 2 & 96.6 & \pm 1.2 \\
\hline Luncheon ham & 86 & \pm 3 & 87.8 & \pm 0.5 & 90.38 & \pm 0.13 & 90.2 & \pm 1.4 \\
\hline Pate & 78.6 & \pm 0.6 & 85.13 & \pm 1.14 & 81.2 & \pm 0.2 & 88.957 & \pm 1.014 \\
\hline Cured ham & 70 & \pm 5 & 73.6 & \pm 0.2 & 67 & \pm 5 & 78 & \pm 6 \\
\hline Cooked ham & 55.7 & \pm 0.3 & 55.13 & \pm 0.13 & 59.1 & \pm 1.2 & 63.3 & \pm 0.6 \\
\hline Chicken drum & 63.57 & \pm 1.06 & 66 & \pm 3 & 69 & \pm 4 & 74 & \pm 2 \\
\hline Pork loin & 52 & \pm 9 & 52 & \pm 6 & 68 & \pm 4 & 68.73 & \pm 0.04 \\
\hline Beef steak & 42 & \pm 2 & 45 & \pm 3 & 51 & \pm 3 & 56 & \pm 2 \\
\hline
\end{tabular}

Focusing on the results when considering the food products and their type of matrix, more concrete patterns could be depicted (Table 4.9). Digestions conducted at intestinal $\mathrm{pH} \mathrm{7,} \mathrm{revealed} \mathrm{that} \mathrm{in} \mathrm{the} \mathrm{protein} \mathrm{fibre} \mathrm{matrices} \mathrm{the} \mathrm{higher} \mathrm{concentration} \mathrm{of}$ bile salts led to a significant increase in total FFA release of up to $300 \mathrm{mg} / \mathrm{g}$ fat, while this effect of bile concentration showed a lower increase in the unstructured matrices (50 $\mathrm{mg} / \mathrm{g}$ fat, except for luncheon ham whose increase was higher). In contrast, the unstructured matrices were more influenced by the $10 \mathrm{mM}$ bile salts concentration in the intestinal $\mathrm{pH} 6$ scenario, which produced an increase of around $150 \mathrm{mg}$ of FFA released per gram of fat as compared to the use of $1 \mathrm{mM}$ bile. At this last $\mathrm{pH} 6$ and $1 \mathrm{mM}$ combination, the natural protein fibres matrices did not show a common pattern. 

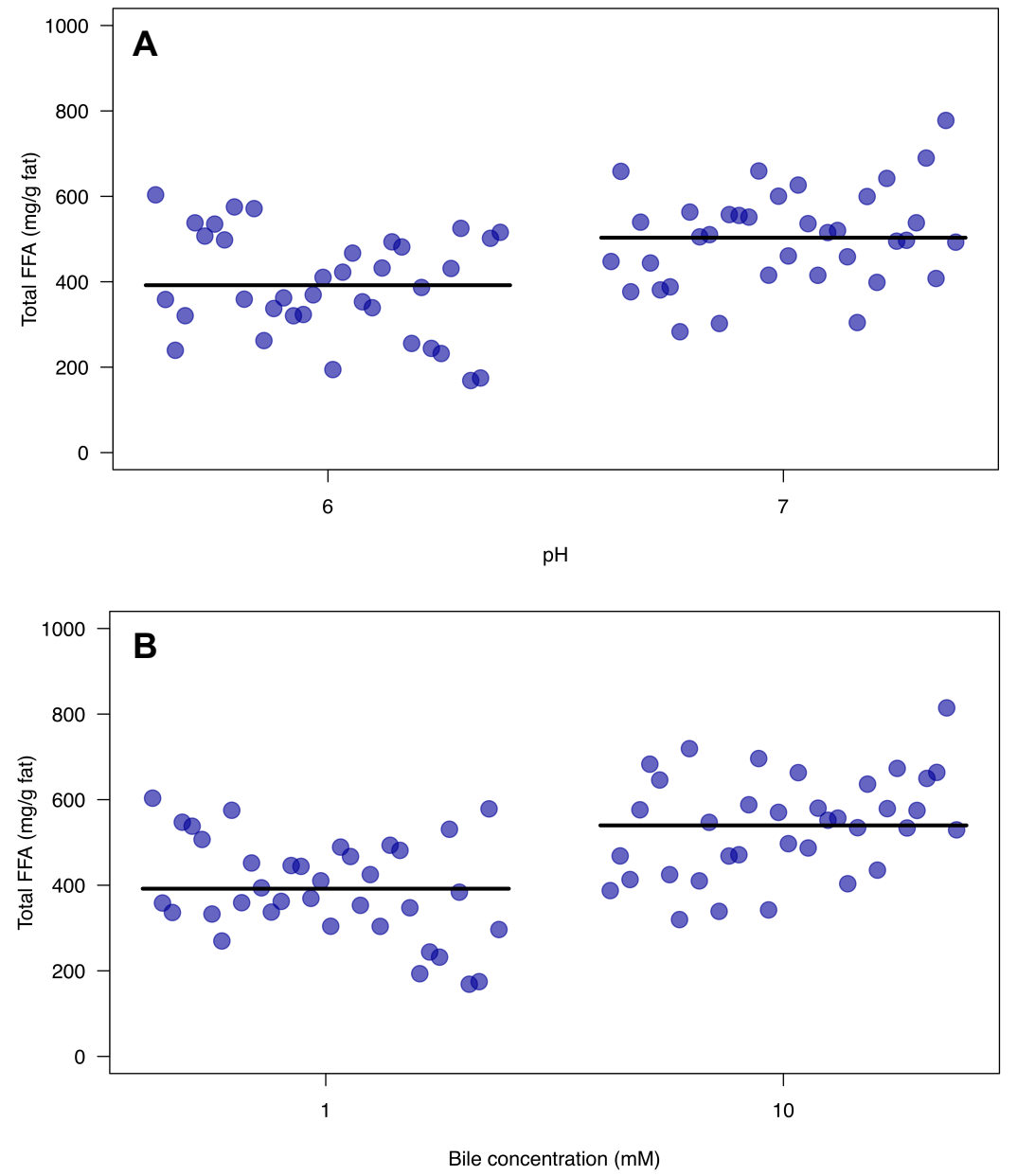

Figure 4.7. Linear mixed regression model plot. (A) Effect of the intestinal $\mathrm{pH}$ (6 or 7) on total FFA: pH 7 allows for significantly higher amount of FFA released ( $<<0.001,95 \%$ CI [53.466, 168.923]). (B) Effect of the bile salts concentration on the total FFA released: $10 \mathrm{mM}$ concentration allows for significantly higher amount of FFA released $(\mathrm{p}<0.001,95 \%$ CI [90.188, 205.645]). 
Table 4.9. Total FFA (mg/g fat) obtained for the different meat matrices (hamburger, sausage, luncheon ham, pate, cured ham, cooked ham, chicken drum, pork loin and beef steak) after the in vitro digestion process using a fixed enzyme dose (2000 LU/ g fat) and different duodenal conditions of $\mathrm{pH}$ and Bile concentration.

\begin{tabular}{|c|c|c|c|c|c|c|c|c|}
\hline & \multicolumn{2}{|c|}{ pH 6 - $1 \mathrm{mM}$} & \multicolumn{2}{|c|}{ pH 6-10 mM } & \multicolumn{2}{|c|}{ pH $7-1 \mathbf{m M}$} & \multicolumn{2}{|c|}{ pH $7-10 \mathrm{mM}$} \\
\hline \multicolumn{9}{|c|}{ Total FFA (mg/g fat) } \\
\hline Hamburger & 253 & \pm 13 & 376 & \pm 58 & 501 & \pm 149 & 554 & \pm 115 \\
\hline Sausage & 525 & \pm 22 & 667 & \pm 26 & 415 & \pm 44 & 490 & \pm 67 \\
\hline Luncheon ham & 498 & \pm 18 & 619 & \pm 3 & 705 & \pm 1 & 902 & \pm 77 \\
\hline Pate & 613 & \pm 153 & 710 & \pm 219 & 680 & \pm 41 & 700 & \pm 147 \\
\hline Cured ham & 344 & \pm 80 & 467 & \pm 66 & 409 & \pm 85 & 600 & \pm 3 \\
\hline Cooked ham & 298 & \pm 29 & 365 & \pm 162 & 416 & \pm 131 & 600 & \pm 177 \\
\hline Chicken drum & 248 & \pm 8 & 249 & \pm 6 & 142 & \pm 109 & 408 & \pm 142 \\
\hline Pork loin & 226 & \pm 8 & 614 & \pm 67 & 556 & \pm 104 & 653 & \pm 29 \\
\hline Beef steak & 298 & \pm 4 & 783 & \pm 10 & 675 & \pm 199 & 860 & \pm 272 \\
\hline
\end{tabular}

Although the $10 \mathrm{mM}$ concentration allowed for a higher amount of FFA release in all the meat products, the increase was up to different extents: the highest was in beef steak (400 mg/g fat) and the lowest in chicken drum (which showed no increase).

Thus, at intestinal $\mathrm{pH} 7$ bile concentration plays a crucial role in natural matrices while it is not relevant in the unstructured matrices; and at $\mathrm{pH}$, the higher bile concentration improves FFA release in unstructured matrices but shows a rather random effect in the natural ones. On the one hand, bile salts are bio-surfactant compounds that play a crucial role in lipid digestion. They adsorb onto lipid droplets and remove proteins, emulsifiers and free fatty acids (lipolysis products). This mechanism facilitates lipases' access and action (Maldonado-Valderrama et al. 2011, Harries et al. 1979). On the other hand, the intestinal $\mathrm{pH}$ environment determines enzymatic activity and also influences the isoelectric point of the protein that may be present at the lipid droplet interface causing isoelectric effects. This fact may change the protein to a cationic form allowing the bind to the anionic bile salts. Consequently, different meat matrices result in different systems 
during digestion in which proteins can interact with the bile salts either promoting or inhibiting the activity of pancreatic lipase (Bauer et al. 2005, Lowe 2002).

To sum up, unstructured matrices led to higher MDI than the structured ones; higher MDI led to higher lipolysis extents (\%); and the intestinal $\mathrm{pH} 7$ and the $10 \mathrm{mM}$ bile salts concentration allowed for higher lipolysis extents. These associations, explained by means of linear regression models, are summarised in Table 4.10.

Table 4.10. Linear mixed regression models explaining the association between the study variables.

\begin{tabular}{|c|c|c|c|c|}
\hline Explained effect & Estimate & $\begin{array}{l}\text { Standard } \\
\text { error }\end{array}$ & $\begin{array}{l}95 \% \\
\text { Confidence } \\
\text { interval (CI) }\end{array}$ & p-value \\
\hline $\begin{array}{l}\text { Effect of the matrix structure } \\
\text { (unstructured vs. structured) on MDI } \\
(\%)\end{array}$ & 19.38 & 5.818 & {$[8.148,30.612]$} & 0.013 \\
\hline $\begin{array}{l}\text { Effect of the MDI (\%) on lipolysis } \\
\text { extent }(\%)\end{array}$ & 8.144 & 0.856 & {$[6.128,9.606]$} & $<0.001$ \\
\hline $\begin{array}{l}\text { Intestinal } \mathrm{pH} \text { (7 vs. } \\
6 \text { ) }\end{array}$ & 111.19 & 29.47 & {$[53.5,168.9]$} & $<0.001$ \\
\hline $\begin{array}{l}\text { Bile salts } \\
\text { concentration }(10 \\
\text { vs. } 1 \mathrm{mM})\end{array}$ & 147.9 & 29.48 & {$[90.2,205.6]$} & $<0.001$ \\
\hline
\end{tabular}

Overall, a main limitation has been identified when aiming at discussing the results. There are no studies conducted in meat products assessing lipolysis, and in contrast, all of them focus on proteolysis. Nonetheless, two papers related to this topic were found: one study assessing lipid digestibility of pork patties depending on the thermal treatment (Hur et al. 2014), and another compiling knowledge about factors affecting lipolysis in fish (Olsen and Ringø 1997). This scarcity has prevented the comparison of the results to previous literature. This is a point of special relevance: characterising the role of lipid digestion in meat products is of upmost necessity, as recently the consumption of red meat products and cold meat derivatives has been classified by the World Health Organisation as a major determinant in the development of cancer (McGuire 2016). In addition, processed meat products have been traditionally characterised by a high content of fat, mainly composed of saturated fatty acids. This 
type of fat is unequivocally associated to the development of nutrition related conditions such as high blood pressure and diseases like obesity (Chen et al. 2016).

\section{CONCLUSION}

In conclusion, fat digestibility in a wide range of meat products has been screened and characterised for the first time regarding their composition, structure and intestinal digestion conditions. The results reveal that lipolysis extent is dependent on the food matrix degradation, and that unstructured processed meats allow for higher amount of free fatty acids release than the natural protein fibrous matrices. In addition to the food structure, the bile salts concentration in the digestion and the $\mathrm{pH}$ in the intestinal digestion medium, contribute significantly to the fate of lipid digestion in meat products.

\section{ACKNOWLEDGEMENTS}

Authors of this paper acknowledge the European Union and the Horizon 2020 Research and Innovation Framework Programme (PHC-26-2014 call Self-management of health and disease: citizen engagement and mHealth) for fully funding this research in the context of MyCyFAPP Project, under grant agreement number 643806. The authors also thank the Conselleria de Educació i Investigació de la Generalitat Valenciana for the $\mathrm{PhD}$ scholarship given to Andrea Asensio Grau. Finally, we thank Antonio Martínez Cañada, from the Data Science and Biostatistics Unit of Instituto de Investigación Sanitaria La Fe, and Arash Javanidejad for the English corrections.

\section{DECLARATION OF INTEREST}

The authors report no conflicts of interest. The authors alone are responsible for the content and writing of the paper.

\section{REFERENCES}

AOAC. 2000. Official methods of analysis of AOAC International. (17th ed.). Gaithersberg, Maryland: Association of Official Chemists. 
Armand, Fieker, A. P., \& Philpott, J. (2011). Enzyme replacement therapy for pancreatic insufficiency: present and future. Clin. Exp. Gastroenteroll. 4: 55. https://doi.org/10.2147/CEG.S17634

Asensio-grau A, Peinado I, Heredia A, Andrés A. (2018). Effect of cooking methods and intestinal conditions on lipolysis, proteolysis and xanthophylls bioaccessibility of eggs. J. Funct Foods.46: 579-586. https://doi.org/10.1016/j.jff.2018.05.025

Bauer E, Jakob S, Mosenthin R. (2005). Principles of physiology of lipid digestion. Asian-Australas J. Anim. Sci. 18: 282-295.

Bax ML, Aubry L, Ferreira C, Daudin JD, Gatellier P, Rémond D, SantéLhoutellier V. (2012). Cooking temperature is a key determinant of in vitro meat protein digestion rate: Investigation of underlying mechanisms. J. Agr. Food Chem. 60: 25692576. https://doi.org/10.1021/jf205280y

Bhutani S, Schoeller DA, Walsh MC, McWilliams C. (2018). Frequency of Eating Out at Both Fast-Food and Sit-Down Restaurants Was Associated With High Body Mass Index in Non-Large Metropolitan Communities in Midwest. Am. J. Health Pr. 32(1), 75-83. https://doi.org/10.1177/0890117116660772

Carriere F, Renou C, Lopez V, De Caro J, Ferrato F, Lengsfeld H, Verger, R. (2000). The specific activities of human digestive lipases measured from the in vivo and in vitro lipolysis of test meals. Gastroenterology. 119: 949-960. https://doi.org/10.1053/gast.2000.18140

Chen M, Li Y, Sun Q, Pan A, Manson JE, Rexrode KM, Hu FB. (2016). Dairy fat and risk of cardiovascular disease in 3 cohorts of US adults. Am. Journal of Clin Nutr. 104. 1209-1217. https://doi.org/10.3945/ajcn.116.134460

Clarke LL, Stien X, Walker NM. (2001). Intestinal bicarbonate secretion in cystic fibrosis mice. JOP : J. Pancreas. 2: 263-267.

Close MA, Lytle LA, Viera AJ. (2016). Is frequency of fast food and sit-down restaurant eating occasions differentially associated with less healthful eating habits? Prev. Med. 4, 574-577. https://doi.org/10.1016/j.pmedr.2016.10.011 
De Souza RJ, Mente A, Maroleanu A, Cozma AI, Ha V, Kishibe T, Anand SS. (2015). Intake of saturated and trans unsaturated fatty acids and risk of all cause mortality, cardiovascular disease, and type 2 diabetes: systematic review and metaanalysis of observational studies. Bmj, h3978. https://doi.org/10.1136/bmj.h3978

Dickinson E. (2012). Emulsion gels: The structuring of soft solids with proteinstabilized oil droplets. Food Hydrocolloids. 28: 224-241. https://doi.org/10.1016/j.foodhyd.2011.12.017

Fang X, Rioux LE, Labrie S, Turgeon SL. (2016). Disintegration and nutrients release from cheese with different textural properties during in vitro digestion. Food Research International, 88, 276-283. https://doi.org/10.1016/j.foodres.2016.04.008

French SA, Story M, Neumark-Sztainer D, Fulkerson JA, Hannan P. (2001). Fast food restaurant use among adolescents: Associations with nutrient intake, food choices and behavioral and psychosocial variables. Int. J. Obes. 25: 1823-1833. https://doi.org/10.1038/sj.ijo.0801820

Gelfond D, Ma C, Semler J, Borowitz D. (2013). Intestinal ph and gastrointestinal transit profiles in cystic fibrosis patients measured by wireless motility capsule. Dig. Dis. Sci. 58: 2275-2281. https://doi.org/10.1007/s10620-012-2209-1

González-Bacerio J, Hernández JR, Martínez ADM. (2010). Las lipasas: enzimas con potencial para el desarrollo de biocatalizadores inmovilizados por adsorción interfacial. Rev. Colomb. Bio. 12: 124-140.

Greenfield H, Arcot J, Barnes JA, Cunningham J, Adorno P, Stobaus T, Muller WJ. (2009). Nutrient composition of Australian retail pork cuts 2005/2006. Food Chem. 117: 721-730. https://doi.org/10.1016/j.foodchem.2009.04.048

Grundy MML, Quint J, Rieder A, Ballance S, Dreiss CA, Cross KL, Wilde PJ. (2017). The impact of oat structure and $\beta$-glucan on in vitro lipid digestion. J. Funct. Foods. 38, 378-388. https://doi.org/10.1016/j.jff.2017.09.011

Guo Q, Ye A, Bellissimo N, Singh H, Rousseau D. (2017). Modulating fat digestion through food structure design. Prog. Lipid Res. 68: 109-118. https://doi.org/10.1016/j.plipres.2017.10.001 
Guo Q, Ye A, Lad M, Dalgleish D, Singh H. (2016). Impact of colloidal structure of gastric digesta on in-vitro intestinal digestion of whey protein emulsion gels. Food Hydrocolloids. 54: 255-265. https://doi.org/10.1016/j.foodhyd.2015.10.006

Hur SJ, Lee SY, Moon SS, Lee SJ. (2014). In vitro effects of cooking methods on digestibility of lipids and formation of cholesterol oxidation products in pork. Korean J. Food Sci. An. 34: 280-286.

Huybrechts I, Maes L, Vereecken C, De Keyzer W, De Bacquer D, De Backer G, De Henauw S. (2010). High dietary supplement intakes among Flemish preschoolers. Appetite, 54(2), 340-345. https://doi.org/10.1016/j.appet.2009.12.012

Lamothe S, Azimy N, Bazinet L. (2014). Function Interaction of green tea polyphenols with dairy matrices in a simulated gastrointestinal environment. Food Func. 5:2621-2631. https://doi.org/10.1039/C4FO00203B

Lamothe S, Corbeil MM, Turgeon SL, Britten M. (2012). Influence of cheese matrix on lipid digestion in a simulated gastro-intestinal environment. Food Func. 3: 724-31. https://doi.org/10.1039/c2fo10256k

Layer P, Keller J. (2003). Lipase Supplementation Therapy: Standards, Alternatives, and Perspectives. Pancreas. 26: 1-7. https://doi.org/10.1097/00006676200301000-00001

López-Gallego F, Betancor L, Hidalgo A, Alonso N, Fernández-Lafuente R, Guisán JM. (2005). Co-aggregation of enzymes and polyethyleneimine: A simple method to prepare stable and immobilized derivatives of glutaryl acylase. Biomacromolecules. 6: 1839-1842. https://doi.org/10.1021/bm050088e

Lowe ME. 2002. The triglyceride lipases of the pancreas. J. Lipid Res. 43: $2007-$ 2016.

Luo J, Taylor C, Nebl T, Ng K, Bennett LE. (2018). Effects of macro-nutrient, micro-nutrient composition and cooking conditions on in vitro digestibility of meat and aquatic dietary proteins. Food Chem. 254: 292-301. https://doi.org/10.1016/j.foodchem.2018.01.164 
Maldonado-Valderrama J, Wilde P, MacIerzanka A, MacKie A. (2011). The role of bile salts in digestion. Adv. Colloid Interface Sci. 165: 36-46. https://doi.org/10.1016/j.cis.2010.12.002

Minekus M, Alminger M, Alvito P, Ballance S, Bohn T, Bourlieu C, Brodkorb A. (2014). A standardised static in vitro digestion method suitable for food-an international consensus. Food Func. 5: 1113-1124. https://doi.org/10.1039/c3fo60702j

Moreira P, Santos S, Padrão P, Cordeiro T, Bessa M, Valente H, Moreira A. (2010). Food patterns according to Sociodemographics, physical activity, sleeping and obesity in Portuguese children. Int. J. Environ. Res. 7: 1121-1138. https://doi.org/10.3390/ijerph7031121

Naikwade SR, Meshram RN, Bajaj AN. (2009). Preparation and In Vivo Efficacy Study of Pancreatin Microparticles as an Enzyme Replacement Therapy for Pancreatitis. Drug Dev. Ind. Pharm. 35: 417-432. https://doi.org/10.1080/03639040802422104

Harries JT, Muller DP, McCollum JP, Lipson A, Roma E, Norman AP. (1979). Intestinal bile salts in cystic fibrosis: studies in the patient and experimental animal. Arch. Dis. Child. 54: 19-24.

Olsen RE and Ringø E. (1997). Lipid digestibility in fish: a review. Recent Res. Dev. Lipid Res.1:199-265.

Peinado I, Larrea V, Heredia A, Andrés A. (2018). Lipolysis kinetics of milkfat catalyzed by an enzymatic supplement under simulated gastrointestinal conditions. Food Biosci. 23: 1-8. https://doi.org/10.1016/j.fbio.2018.02.011

Pereira PM. de CC, Vicente A. F. dos R. B. (2013). Meat nutritional composition and nutritive role in the human diet. Meat Sci. 93: 586-592. https://doi.org/10.1016/j.meatsci.2012.09.018

Pérez-Rodrigo C, Gil Á, González-Gross M, Ortega RM., Serra-Majem L, Varela-Moreiras G, Aranceta-Bartrina J. (2015). Clustering of dietary patterns, lifestyles, and overweight among Spanish children and adolescents in the ANIBES study. Nutrients, 8(1), 1-17. https://doi.org/10.3390/nu8010011 
Prazeres DMF, Garcia FAP, Cabral MS. (1994). Bioprocess Engineering Continuous lipolysis in a reversed micellar membrane bioreactor, 10, 21-27.

Roccaldo R, Censi L, D’Addezio L, Toti E, Martone D, D'Addesa D, Cernigliaro A. (2014). Adherence to the Mediterranean diet in Italian school children (The ZOOM8 Study). Int- J. Food Sci. Nutr. 65: 621-628. https://doi.org/10.3109/09637486.2013.873887

Rovner AJ, Schall JI, Mondick JT, Zhuang H, Mascarenhas MR. (2013). Delayed small bowel transit in children with cystic fibrosis and pancreatic insufficiency. J. Pediatr. Gastroenterol. Nutr. 57(1), 81-84. https://doi.org/10.1097 /MPG.0b013e318290d112

Ryan L, O'Connell O, O’Sullivan L, Aherne SA, O'Brien NM. (2008). Micellarisation of Carotenoids from Raw and Cooked Vegetables. Plant Food Hum. Nutr. 63: 127-133. https://doi.org/10.1007/s11130-008-0081-0

Turck D, Braegger CP, Colombo C, Declercq D, Morton A, Pancheva R, Wilschanski M. (2016). ESPEN-ESPGHAN-ECFS guidelines on nutrition care for infants, children, and adults with cystic fi brosis. Clin. Nutr. 35: 557-577. https://doi.org/10.1016/j.clnu.2016.03.004

Vu MK, Vecht J, Eddes EH, Biemond I, Lamers CB, Masclee AA. (2000). Antroduodenal motility in chronic pancreatitis: are abnormalities related to exocrine insufficiency? NAL AND LIVER PHYSIOLOGY Am. J. Physiol.-Gastroint. Liver Physiol. 278: 458-466.

Whitcomb DC, Lehman GA, Vasileva G, Malecka-Panas E, Gubergrits N, Shen Y, Caras S. (2010). Pancrelipase delayed-release capsules (CREON) for exocrine pancreatic insufficiency due to chronic pancreatitis or pancreatic surgery: A doubleblind randomized trial. Am. J. Gastroenterol. 105: 2276-2286. https://doi.org/10.1038/ajg.2010.201 


\section{CHAPTER 3}

\section{EFFECT OF MILK TYPE AND AGING OF CHEESE ON LIPIDS AND PROTEIN DIGESTIBILITY UNDER DIFFERENT INTESTINAL CONDITIONS}

The study of cheese digestibility is the focus of the third chapter of this thesis, as this food contributes the most to the dietary intake of dairy fat, as reported in a cohort of pediatric patients with CF, coursing with digestive disorders. In this study both ripening and milk origin were evaluated as factors affecting digestibility of lipid and protein in cheese.

Cheese can be consumed after milk coagulation, as occurs in fresh cheese, or after a subsequent maturation period, as in the case of ripened cheeses. During ripening both lipid and protein are enzymatically hydrolysed affecting cheese matrix and its flavour. These physicochemical changes might influence intestinal lipid and protein digestibility. Another relevant variable that could affect proteolysis and lipolysis is the milk origin. There are different types of milk usually used in the cheese manufacturing such as goat, cow and sheep. Depending of the milk type the fatty acids conforming the triglyceride can vary, affecting thus lipid digestion.

Thus, the aim of this study was to in vitro evaluate the effect of ripening time and milk composition together with the intestinal conditions of $\mathrm{pH}$, bile and pancreatic concentrations on protein and lipid digestibility in cheese. For this purpose, the experimental design followed the same approach previously explained (Section Materials and Methods). To address the aim of this study a static in vitro gastrointestinal digestion was simulated and then, digested samples were centrifugated and filtrated to separate the liquid fraction (bioaccessible) from the solid part. As for the analytical determinations, the matrix degradation index was measured in the solid fraction to establish the degree of disaggregation of the cheese matrices during simulated digestion. Proteolysis and lipolysis were measured in the bioaccessible fraction by following the same methodology as reported in the previous chapters: the trichloroacetic acid (TCA) 
soluble protein and the colorimetric kit. In addition, in this study, lipolysis was also assessed by gas chromatography mass spectrometry (GC-MS). This analytical technique allows for identifying all the individual fatty acids present in the sample and also the profile of the fatty acids released after digestion.

According to the obtained results, it can be stated that cheeses were more digestible (lipolysis extent values closed to $100 \%$ ) than meat products (chapter 2) under standard intestinal conditions ( $\mathrm{pH} \mathrm{7,} \mathrm{bile} \mathrm{salt} \mathrm{concentration} 10 \mathrm{mM}$ ). Under the most unfavourable conditions ( $\mathrm{pH} \mathrm{6}$, bile salt concentration $1 \mathrm{mM}$ ), however, only fresh goat cheese achieved $100 \%$ of lipolysis extent at a lipase concentration of $2000 \mathrm{LU} / \mathrm{g}$ fat. Concerning the fatty acid profile of the undigested cheeses, all of them were characterised by the main proportion of palmitic acid, followed by oleic and stearic, other short-chain saturated fatty acids having a relevant presence as well. On the other hand, the optimal intestinal conditions led to a higher fatty acids release compared to the $\mathrm{CF}$ intestinal conditions in all cheeses. Regarding protein digestion, higher proteolysis in mild and aged cheeses was found, as the ripening process is known to contribute to protein hydrolysis. In case of fresh cheeses, both cow and goat cheeses reached similar values of proteolysis. The intestinal scenario of CF led to lower proteolysis than in the case of the standard intestinal conditions, as pancreatic proteases have optimal activity at intestinal $\mathrm{pH} 7$.

The results also showed different behaviours in lipolysis when different pancreatin concentrations were tested in the simulation of intestinal digestion of CF. The fresh goat cheese reached maximum lipolysis $(100 \% \pm 10)$ already at the dose of 2000 $\mathrm{LU} / \mathrm{g}$ fat and it did not significantly increase with higher concentrations. The same pattern was noticed in the mild-aged cheese, but in this case the optimal dose that maximises lipolysis extent (50\%) was $3000 \mathrm{LU} / \mathrm{g}$ lipid. The other varieties, including fresh cow cheese and aged cheese obtained higher lipolysis extents with increasing pancreatin concentrations up to $4000 \mathrm{LU} / \mathrm{g}$ fat, reaching maximum extents of 60 and $80 \%$ respectively. This chapter concludes, therefore, with a practical recommendation of pancreatic enzyme supplements for patients with pancreatic insufficiency of 2000 $\mathrm{LU} / \mathrm{g}$ fat for fresh goat cheese, $3000 \mathrm{LU} / \mathrm{g}$ fat for mild-aged cheese, and $4000 \mathrm{LU} / \mathrm{g}$ fat 
for fresh cow cheese and aged cheese. In addition, the preferable consumption of goat fresh cheese is advised, as this is the only assessed cheese type being able to achieve maximum lipolysis extent in CF intestinal conditions. 


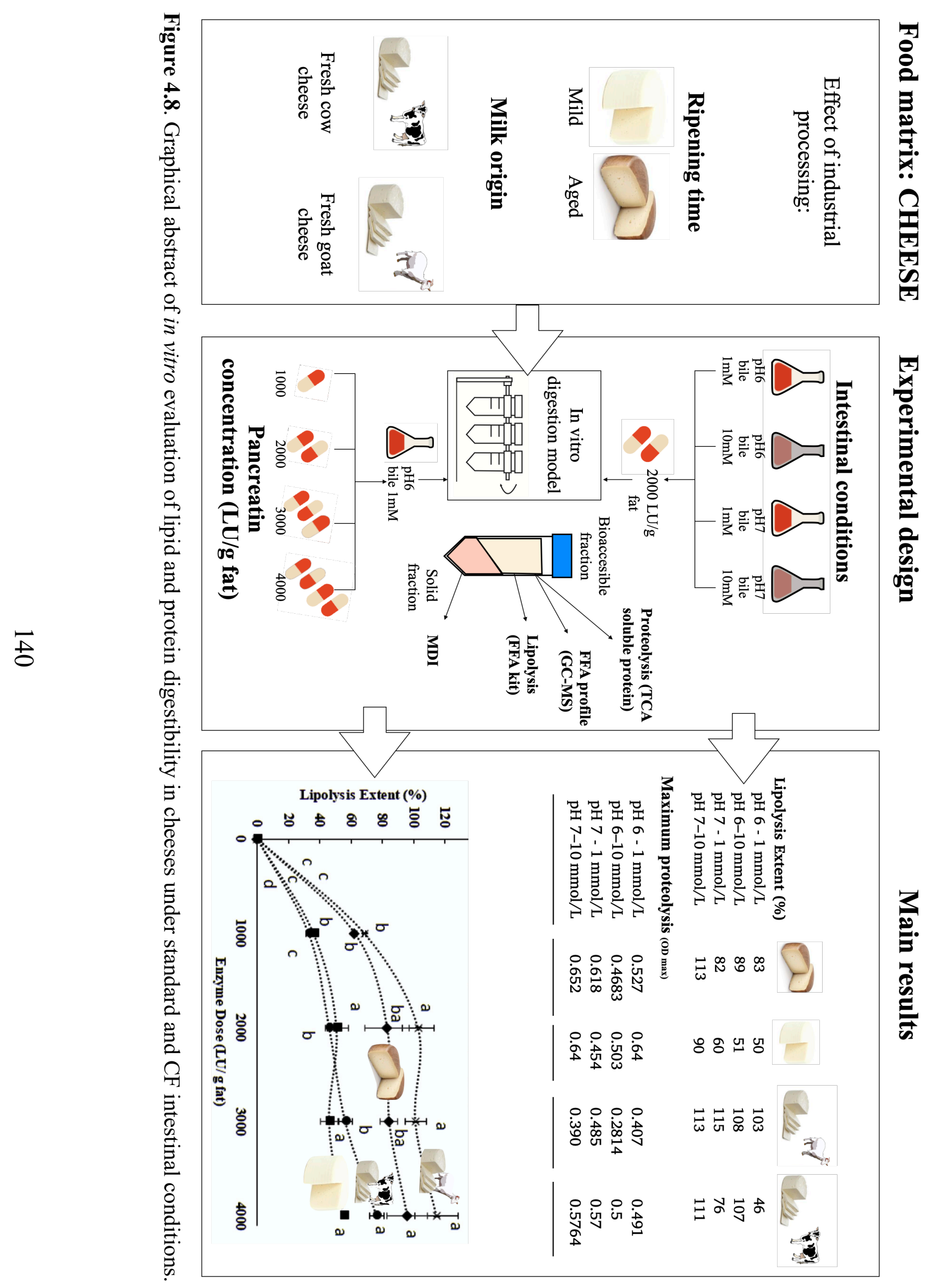


Title: In vitro study of cheese digestion: effect of type of cheese and intestinal conditions on macronutrients digestibility

Andrea Asensio-Grau, Irene Peinado, Ana Heredia and Ana Andrés

LWT - Journal, 46, 579-586.

\title{
https://doi.org/10.1016/j.lwt.2019.108278
}

\begin{abstract}
Exocrine Pancreatic Insufficiency (EPI) implies maldigestion, being pancreatic enzyme replacement therapy the treatment to enhance digestibility. This study aims at analysing the influence of cheese-related factors and intestinal conditions on macronutrients digestibility. Fresh-cow, fresh-goat, mild and aged cheeses were in vitro digested under different intestinal conditions of $\mathrm{pH}$ (6 or 7$)$, bile concentration ( 1 or $10 \mathrm{mmol} / \mathrm{L})$ and pancreatic enzymes $(0-4000 \mathrm{LU} / \mathrm{g}$ fat $)$ in order to in vitro mimic the intestinal conditions of a healthy adult and of an individual suffering of EPI. Under intestinal conditions of EPI ( $\mathrm{pH} 6$, bile $1 \mathrm{mmol} / \mathrm{L})$, lipids of fresh-goat and aged cheeses were more easily digested than those of fresh-cow and mild cheeses. In fact, $2000 \mathrm{LU} / \mathrm{g}$ fat of enzymatic dosage was enough to achieve a lipolysis extent of 80 and $100 \%$ in aged and fresh-goat cheeses, respectively. In contrast, proteolysis was higher in fresh-cow cheese and ripened (mild or aged) than in fresh-goat one regardless the intestinal conditions. Only in ripened-cheeses, the proteolysis significantly increased at dose of enzymes does.
\end{abstract}

Keywords: Pancreatic insufficiency; Cheese; Lipolysis; Proteolysis; Fatty acids profile 


\section{INTRODUCTION}

Food lipids are important in diets of infants and children, especially when digestive disorders occur such as exocrine pancreatic insufficiency (EPI), as they supply metabolic energy and phospholipids, the main constituents of biological membranes (Briefel, Reidy, Karwe, \& Devaney, 2004). Among lipid-containing foods, dairy products are highly consumed by childhood population (Calvo-Lerma et al., 2019). Cheese is particularly rich in lipid and a good source of essential nutrients such as protein, bioactive peptides, vitamins and minerals (Walther, Schmid, Sieber, \& Wehrmüller, 2008). The three major constituents of cheese are protein, fat and water, and all them conform their matrix structure. Protein matrix consists of casein particles that are bonded with calcium ions through electrostatic forces or hydrophobic aggregations, which entrap fat globules. Water content depends on the manufacturing process that directly influences lipid and protein content. Cheese can be consumed directly after its elaboration (fresh cheese), or after a ripening stage (ripened cheese). During ripening, proteolysis disaggregates the casein network that conforms the cheese matrix, while lipolysis is the main process determining the flavour. These physicochemical events might influence lipid and protein bioaccessibility (AyalaBribiesca, Lussier, Chabot, Turgeon, \& Britten, 2016). Besides cheese processing, milk origin also determines protein and lipid content. $98 \%$ of dairy lipids are triacyglycerides (TAG) (Ayala-Bribiesca, Turgeon, \& Britten, 2017); being the three major predominant free fatty acids (FFA) forming part of TAG the following: palmitic acid $\left(\mathrm{C}_{16: 0}\right)$, stearic acid $\left(\mathrm{C}_{18: 0}\right)$ and oleic acid $\left(\mathrm{C}_{18: 1}\right.$ cis (n-9)) (Ceballos et al., 2009). The origin of milk (cow, goat or sheep milk), also influences lipid digestibility, resulting goat milk fat in better digestibility as compared to cow milk fat (Alférez et al., 2001).

The intestinal environment as well as the intrinsic matrix composition of food have been reported to influence the digestion process (Calvo-Lerma, Fornés-Ferrer, Heredia \& Andrés, 2018; Hur, Lim, Decker, \& McClements, 2011). Lipid digestion requires complex mechanisms, such as biliar secretion to emulsify fat globules (fat micelles), making them accessible for the pancreatic enzymes. However, gastrointestinal environment can vary among different individuals (Shani-Levi et al., 2017). Concretely, 
in the EPI scenario, the obstruction of the pancreatic duct results in deficient secretion of pancreatic juice containing pancreatin and sodium bicarbonate. Besides, alteration of the biliary duct can lead to a reduced secretion of bile salts. This situation causes maldigestion and mal-absorption, mainly of fats (Whitcomb et al., 2010). To revert the situation, oral pancreatic enzyme replacement therapy is the life-long treatment patients have to adhere to Turck et al., 2016.

In this context, the aim of the present study was to evaluate, by means of a static in vitro gastrointestinal digestion model, the influence of some intestinal conditions of $\mathrm{pH}$ (6 and 7), bile concentration ( 1 and $10 \mathrm{mmol} / \mathrm{L}$ ) and pancreatic supplementation ( 0 4000 Lipase Units (LU)/g fat) associated to EPI, on protein and lipid digestion in cheeses with different milk origin (cow or goat) and ripening time (mild or aged).

\section{MATERIALS AND METHODS}

\subsection{Materials}

Four types of cheese were used in this study. On the one hand, two cheeses of different ripening conditions but with the same milk composition (55\% cow, $25 \%$ sheep and $20 \%$ goat), mild-cheese ( 30 days of aging time) and aged-cheese (240 days of aging time). On the other hand, cheeses with the same elaboration process but different milk origin (100\% goat or $100 \%$ cow): fresh goat cheese and fresh cow cheese were also assessed. All cheeses were produced by "Queserías Entrepinares, S.A.U." and distributed in a local supermarket in Valencia (Spain).

The simulated digestive fluids were prepared with $\mathrm{KCl}, \mathrm{KH}_{2} \mathrm{PO}_{4}, \mathrm{NaCl}, \mathrm{NaHCO}_{3}$, $\mathrm{MgCl}_{2}\left(\mathrm{H}_{2} \mathrm{O}\right)_{6},\left(\mathrm{NH}_{4}\right)_{2} \mathrm{CO}_{3}, \mathrm{CaCl}_{2}$, human $\alpha-$ amylase (1000 - $3000 \mathrm{U} / \mathrm{mg}$ protein), pepsin from porcine gastric mucosa ( $\geq 2500 \mathrm{U} / \mathrm{mg}$ protein) and bovine bile extract all of them from Sigma-Aldrich Chemical Company (St Louis, MO, USA). The pancreatic enzymes supplements came from Kreon 10,000 LU (Mylan, USA), each capsule containing $150 \mathrm{mg}$ of gastro-resistant microspheres including porcine pancreatic enzyme equivalent to 10,000 lipase units, 8,000 amylase units, and 600 protease units.

For the analytical determinations, Triton-X $100 \% 100 \%$, trichloroacetic acid (TCA), hexane,and the analytical standards were acquired from Sigma-Aldrich 
Chemical Company (St Louis, MO, USA), and ethanol (95\% v/v for analysis), $\mathrm{NaOH}$ and $\mathrm{HCl}$, were from AppliChem Panreac.

\subsection{Experimental design}

The experimental design consisted in two sets of experiments. In the first set, the dose of enzyme supplement was remained fixed at $2000 \mathrm{LU} / \mathrm{g}$ of fat, and the study variables were different combinations of intestinal $\mathrm{pH}$ and bile salts concentration (mmol/L): 6-1, 6-10, 7-1 and 7-10, with the purpose of analysing the impact of intestinal conditions on lipolysis and proteolysis. The intestinal condition of $\mathrm{pH} 6$ and $1 \mathrm{mmol} / \mathrm{L}$ would represent the worst unfavourable intestinal scenario in EPI (Gelfond, Ma, Semler, \& Borowitz, 2013; Seksik et al., 2018). The intestinal condition of pH 7 and $10 \mathrm{mmol} / \mathrm{L}$ bile salts would correspond to the gastrointestinal scenario of a healthy subject (Minekus et al., 2014). In the second set, the intestinal conditions of EPI were simulated (pH $6-1$ $(\mathrm{mmol} / \mathrm{L}))$ and different doses of enzyme supplement $(0,1000,2000,3000$ and 4000 $\mathrm{LU} / \mathrm{g}$ of lipid) were tested, in order to assess the influence of supplement concentration on lipolysis and proteolysis. A blank of digested fluids in each intestinal condition was also analysed in the absence of food. All the experiments were performed at least in triplicate.

\subsection{In vitro digestion}

Fat, water, carbohydrate and protein contents in all cheeses were determined before digestion with the official methods (AOAC, 2000). In vitro digestion was conducted on the basis of the INFOGEST Cost Action international protocol (Minekus et al., 2014) with some modifications in order to simulate EPI conditions (Asensio-Grau, Peinado, Heredia, \& Andrés, 2018). Digestion fluids were prepared from the corresponding stock solutions according to Minekus et al. (2014). Before each experiment, the enzymatic activity was cheeked according to the protocol published by Carriere et al. (2000). The In vitro digestion process was conducted as follows: Oral stage: Simulated Salivary Fluid (SSF; pH 7) was added to the cheese sample in a ratio $1: 1(\mathrm{w} / \mathrm{v})$ properly homogenized using a kitchen blender for $3 \mathrm{~min}$ at $37^{\circ} \mathrm{C}$ (Vario 
Mixer, Ufesa $600 \mathrm{~W}$ ). Human $\alpha$ - amylase was added as a part of SSF to reach a concentration in the salival mixture of $75 \mathrm{U} / \mathrm{ml}$.

Gastric stage: Subsequently, Simulated Gastric Fluid (SGF; pH 3) was added to each tube in a 1:1 (v/v) ratio including pepsin to reach a concentration in the gastric mixture of $2000 \mathrm{U} / \mathrm{ml}$. The $\mathrm{pH}$ of the mixtures was adjusted with $\mathrm{HCl}(1 \mathrm{~N})$ to $\mathrm{pH} 3$. Tubes were head-over-heels rotated at $55 \mathrm{rpm}$ for $2 \mathrm{~h}$ at $37{ }^{\circ} \mathrm{C}$ using Intell - Mixer RM - 2 (Elmi Ltd, Riga, LV - 1006, Latvia) in an incubator chamber (JP Selecta SA, Barcelona). The pancreatic supplement was added at the gastric stage, mimicking the incorporation of pancreatic enzyme replacement therapy to the digestion process.

Intestinal stage: After the gastric stage, Simulated Intestinal Fluid (SIF; pH 6 or 7) was added in 1:1 (v/v) ratio to each tube containing the gastric chime. The mixtures were adjusted to $\mathrm{pH} 6$ or 7 , depending on the experimental set with $\mathrm{NaOH}(1 \mathrm{~N})$. Then, samples were rotated head-over-heels at $55 \mathrm{rpm}$ for $2 \mathrm{~h}$ at $37{ }^{\circ} \mathrm{C}$. During digestion, $\mathrm{pH}$ was controlled to keep the experimental conditions, as $\mathrm{pH}$ below 5.7 might inactivate lipase activity (González-Bacerio, Hernández, \& Martínez, 2010; Prazeres, Garcia, \& Cabral, 1994).

\subsection{Analytical determinations}

\subsubsection{Matrix Degradation Index (MDI (\%))}

Matrix degradation Index (\%) was calculated from the proportion of solids that were finely dispersed in the digested juice after the intestinal stage (Lamothe, Corbeil, Turgeon, \& Britten, 2012).The total content of the tubes was centrifuged (4000 x g-force $\left.20 \mathrm{~min}, 4^{\circ} \mathrm{C}\right)$ and then filtered on a metallic sieve (1.6 $\mathrm{mm} \times 1.6 \mathrm{~mm}$ mesh) in order to separate the solid fraction. The liquid fraction was kept for lipolysis extent determination. The remaining liquid phase was freeze-dried $\left(-40^{\circ} \mathrm{C}\right.$ and $1.25 \mathrm{mbar}$, Telstar, Terrasa, Spain) and used for fatty acids profile analysis by gas chromatography. The solid large particles from digestion were transferred to an aluminium plate and then placed in a force air oven at $60{ }^{\circ} \mathrm{C}$ for 48 hours to determine the mass of large cheese particles. 


\subsubsection{Proteolysis}

Proteolysis was determined by measuring the soluble protein fraction in trichloroacetic acid (TCA) (Lamothe, Azimy, \& Bazinet, 2014) at different times ( 0,10 , 20, 60, 90 and $120 \mathrm{~min}$ ) during gastric and intestinal stages. Aliquots of digested samples were extracted and TCA was added to a final concentration of $15 \%(\mathrm{w} / \mathrm{w})$, and then centrifuged at $4000 \mathrm{~g}$-force for $15 \mathrm{~min}$ at $4^{\circ} \mathrm{C}$. Then, the supernatant containing the hydrolysed peptides was mixed with glycine buffer, and the absorbance (OD) was measured at $280 \mathrm{~nm}$ using a spectrophotometer (UV/vis, Beckman Coulter). Proteolysis was determined estimated by considering two parameters $\mathrm{OD}_{\max }$ and $\Delta \mathrm{OD} / \mathrm{h}$ initial from the mathematical model published by Bax, Aubry, Ferreira, Daudin, \& Gatellier (2012) and using a Solver of Microsoft ${ }^{\circledR}$ Excel in order to estimate calculate estimate both parameters.

\subsubsection{Lipolysis extent (\%)}

Aliquots from the liquid fraction of digested samples were diluted with a solution (5.6\% Triton X-100 and $6 \%$ ethanol in water) to solubilize free fatty acids ensuring lipase activity inactivation (Lamothe, Corbeil, Turgeon, \& Britten, 2012). FFA release after digestion was measured by means of an enzymatic kit (Roche Diagnostics, Indianapolis, IN, USA) using a spectrophotometer (UV/vis, Beckman Coulter). Palmitic acid standard was used for quantitative determination of FFA. Lipolysis extent (\%) was expressed as the percentage of total fatty acids released after complete digestion, considering the maximum release of 2 fatty acids per 1 molecule of triacylglycerol and the average molecular weight of milk triglycerides $741 \mathrm{~g} / \mathrm{mol}$ (Hunter, 2001). Lipolysis of the studied cheeses was also determined before digestion, to estimate lipid hydrolysis during ripening.

\subsubsection{Free fatty acid profile}

Chromatography mass spectrometry (GC-MS) was used for identification of FFA from cheese before and after digestion. Undigested samples were subjected to a Soxhlet extraction (AOAC, 2000), while digested samples were extracted with hexane. Lipid samples needed a transesterification from fatty acids to methyl esters (FAMEs) with $\mathrm{BF}_{3}$ and methanol at $20^{\circ} \mathrm{C}$ according to the IUPAC standard method (Yaich et al., 2011). 
Then, samples were analysed with an Agilent 5977A system and an HP-5MS UI (Agilent) (Colum: $30 \mathrm{~m} \times 0.25 \mathrm{~mm}, 0.25 \mu \mathrm{m}$ film thickness) with helium as carrier agent (1 $\mathrm{ml} / \mathrm{min})$. Extraction, esterification and the analysis conditions were previously described by Paz-Yépez, Peinado, Heredia, \& Andrés (2018).

\subsection{Statistical analyses}

Simple ANOVA analyses were performed to assess the statistical significance of the intestinal conditions variables, milk origin and maturation stage on MDI, proteolysis, lipolysis extent, and free fatty acid profile in digested cheeses. Statgraphics Centurion was used and the analyses were conducted with at least a significance of $95 \%$ ( $p$-value $<0.05)$.

\section{RESULTS AND DISCUSSION}

\subsection{Influence of the intestinal $\mathrm{pH}$ and bile concentration on macronutrients digestibility of different fresh and ripened cheeses}

As previously mentioned, the studied cheeses were characterized before digestion in terms of fat, protein and carbohydrate contents ( $g$ of each macronutrient/ $g$ of dry matter). Fresh-cow cheese $(0.32 \pm 0.03)$ presented lower fat content than the fresh-goat (0.50 \pm 0.06$)$, mild $(0.544 \pm 0.003)$ and aged cheeses $(0.51 \pm 0.04)$. However, the protein content was similar in all of them $(\approx 0.3 \mathrm{~g} / \mathrm{g}$ dry matter). Regarding carbohydrate content, as expected, ripened cheeses presented less content (aged cheese $(0.015 \pm 0.002)$ and mild cheese (0.022 \pm 0.003$)$ ) compared to fresh ones (fresh cow cheese $(0.18 \pm 0.05)$ and fresh goat cheese $(0.097 \pm 0.04))$. These differences can be attributed to the different composition of cow and goat milks, in terms of lipids for instance, and to the cheesemaking process. In case of fresh cheeses, the rennet is immediately added after milk pasteurization, when temperature reaches $32-37{ }^{\circ} \mathrm{C}$, and then mixed to coagulate the milk. After 30 minutes, draining and pressing proceed. Conversely, ripened cheeses are kept on a maturating chamber after coagulation, where the temperature and time of the process are controlled. This situation leads to ripened cheeses resulting in an additional loss of moisture content with an increase of protein and lipids in ripened cheeses 
compared to fresh ones, but in a lower carbohydrate content due to bacterial conversion of carbohydrates into other metabolic compounds.

Table 4.11 reports the values for MDI (\%) and lipolysis extent (\%) achieved in cheeses digested at a fixed enzyme dose of $2000 \mathrm{LU} / \mathrm{g}$ fat but different gastrointestinal conditions of $\mathrm{pH}(6$ or 7$)$ and bile concentration ( 1 or $10 \mathrm{mmol} / \mathrm{L})$. As observed, both fresh cheeses presented higher MDI (\%) under healthy conditions of $\mathrm{pH} 7$ and bile concentration of $10 \mathrm{mmol} / \mathrm{L}$; whereas in ripened cheeses, similar values of MDI (\%) (between 73 and 81) were found regardless the intestinal conditions, and being higher than the values obtained for fresh varieties. During fresh cheese production, and directly after acidic or enzymatic coagulation of caseins, cheeses are pressed and packaged resulting in softer structures than those of the ripened ones, but with a very stable threedimensional casein matrix (Pastorino, Hansen, \& McMahon, 2003). During the further ripening stage applied in the production of aged cheeses, proteolysis, lipolysis and the metabolism of residual lactose, lactate and citrate, are the three primary routes by which biochemical activity continues. The relative importance of each of these processes is largely dependent on cheese variety; however, proteolysis has been pointed out as the most complex mechanism, therefore playing a significant role during ripening of nearly all varieties. In fact, Karaman and Akalin (2013) reported a decrease of the hardness and cohesiveness in ripened cheeses as a consequence of proteolysis. In the same way, lipolysis contributes to the volatile compounds profile as well as to unctuousness. Therefore, proteolysis and lipolysis occurring during ripening stage could favour further matrix degradation during the gastrointestinal track.

Concerning lipolysis extent after digestion, complete lipolysis $(\approx 100 \%)$ was achieved in most of the studied cheeses under the standard healthy intestinal conditions (pH 7 and bile concentration $10 \mathrm{mmol} / \mathrm{L}$ ). However, these results also show that the different manufacturing processes can influence the bioavailability of lipids at suboptimal intestinal conditions of 6 and bile concentration of $1 \mathrm{mmol} / \mathrm{L}$. Concretely, lipolysis was found to be higher in aged cheese and fresh goat cheese than in mild and fresh cow cheese at these intestinal conditions. Aged cheese showed a significant higher lipolysis extent compared to mild cheese, being the only difference between them the 
aging time: 30 days for mild and 240 days for aged cheese. The lipolysis extent found in these cheeses before digestion was $1.6 \pm 0.3 \%$ and $3.4 \pm 0.5 \%$, respectively; while the extent of lipolysis in fresh cow and fresh goat cheese was around $0.4 \pm 0.2 \%$ in both cases. During ripening process, products of hydrolysis could enhance the further lipolysis during digestion because of their emulsifying capacity (MaldonadoValderrama, Wilde, MacIerzanka \& MacKie, 2011).

Table 4.11. Matrix Degradation Index (\%) and Lipolysis extent (\%) of different cheeses (aged, mild, fresh goat and fresh cow) digested at fixed enzyme dose of $2000 \mathrm{LU} / \mathrm{g}$ fat and different duodenal conditions of $\mathrm{pH}$ and Bile concentration.

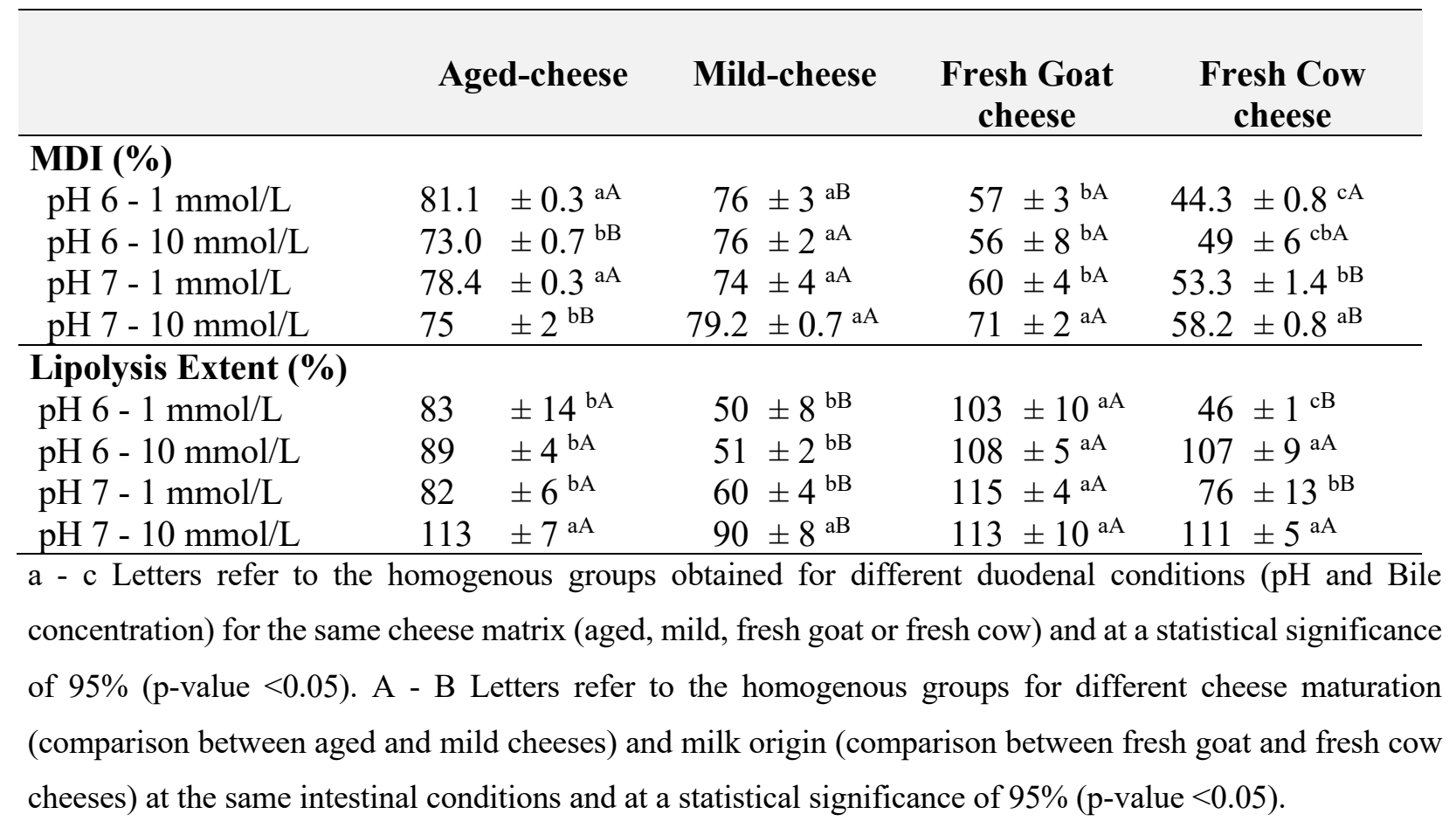

Bile concentration played a crucial significant role on lipolysis attained in fresh cow cheese at both $\mathrm{pH} 6$ and 7, and aged and mild cheese at pH 7. However, lipolysis extent was not affected in fresh goat cheese, with complete lipid hydrolysis regardless the intestinal $\mathrm{pH}$ or bile salt concentration. Goat milk is richer in short chain fatty acids than cow milk. Short chain fatty acids are easier to hydrolyse by lipases, becoming the role of bile salts or $\mathrm{pH}$ less important (Arora, Bhojak \& Joshi, 2013). Therefore, these 
results revealed that triglycerides from fresh goat cheese are more digestible than in fresh cow type, which increases their nutritional value and their health benefits.

FFA profiles resulting from cheese digestion were determined in two intestinal scenarios, corresponding to the healthy situation ( $\mathrm{pH} 7$ and bile $10 \mathrm{mMmmol} / \mathrm{L}$ ) and the EPI conditions $(\mathrm{pH} 6$ and bile $1 \mathrm{mMmmol} / \mathrm{L}$ ) in order to deeper understand the consequences of the EPI disorder on lipid mal-digestion.

Additionally, FFA profile of mild, aged, fresh goat and fresh cow cheeses (g FFA/100 g total fatty acids) was analysed prior digestion, and results are gathered in Table 4.12. The predominant FFAs found in all cheeses were lauric acid $\left(\mathrm{C}_{12: 0}\right)$, palmitic acid $\left(\mathrm{C}_{16: 0}\right)$ and stearic acid $\left(\mathrm{C}_{18: 0}\right)$ above saturated FFA; and oleic acid $\left(\mathrm{C}_{18: 1}\right)$ over the unsaturated ones. Concretely, these four FFA entail the 85.8, 86.4, 83.8 and $83.7 \%$ of total FFA in aged, mild, fresh goat and fresh cow cheeses, respectively. Particularly, the main differences between fresh goat and fresh cow cheeses were found in the amounts of saturated fatty acids $\left(\mathrm{C}_{6: 0}, \mathrm{C}_{8: 0}, \mathrm{C}_{10: 0}, \mathrm{C}_{12: 0}\right.$ and $\left.\mathrm{C}_{20: 0}\right)$. Similar FFA distribution was reported for fresh goat and fresh cow cheeses in other studies (Ceballos et al., 2009; Rodríguez-Alcalá, Harte \& Fontecha, 2009), differences beingattributed to milk origin. Aged and mild cheeses presented a very similar FFA profile, as expected, since they are made from the same mixture of milks, and in the same proportion, being the only difference between them the aging time. However, aged cheese presented a slightly, although statistically significant, higher amount of $\mathrm{C}_{12: 0}(16.93 \%)$ and $\mathrm{C}_{14: 0}(3.007 \%)$; while mild cheese showed a higher content in $\mathrm{C}_{18: 0}(17.58 \%)$. The difference found in the content of myristic acid $\left(\mathrm{C}_{14: 0}\right)$ between fresh and ripened cheeses might be attributed to the action of lipolytic agents during the maturation process, such as enzymes from milk, rennet and the microflora. 


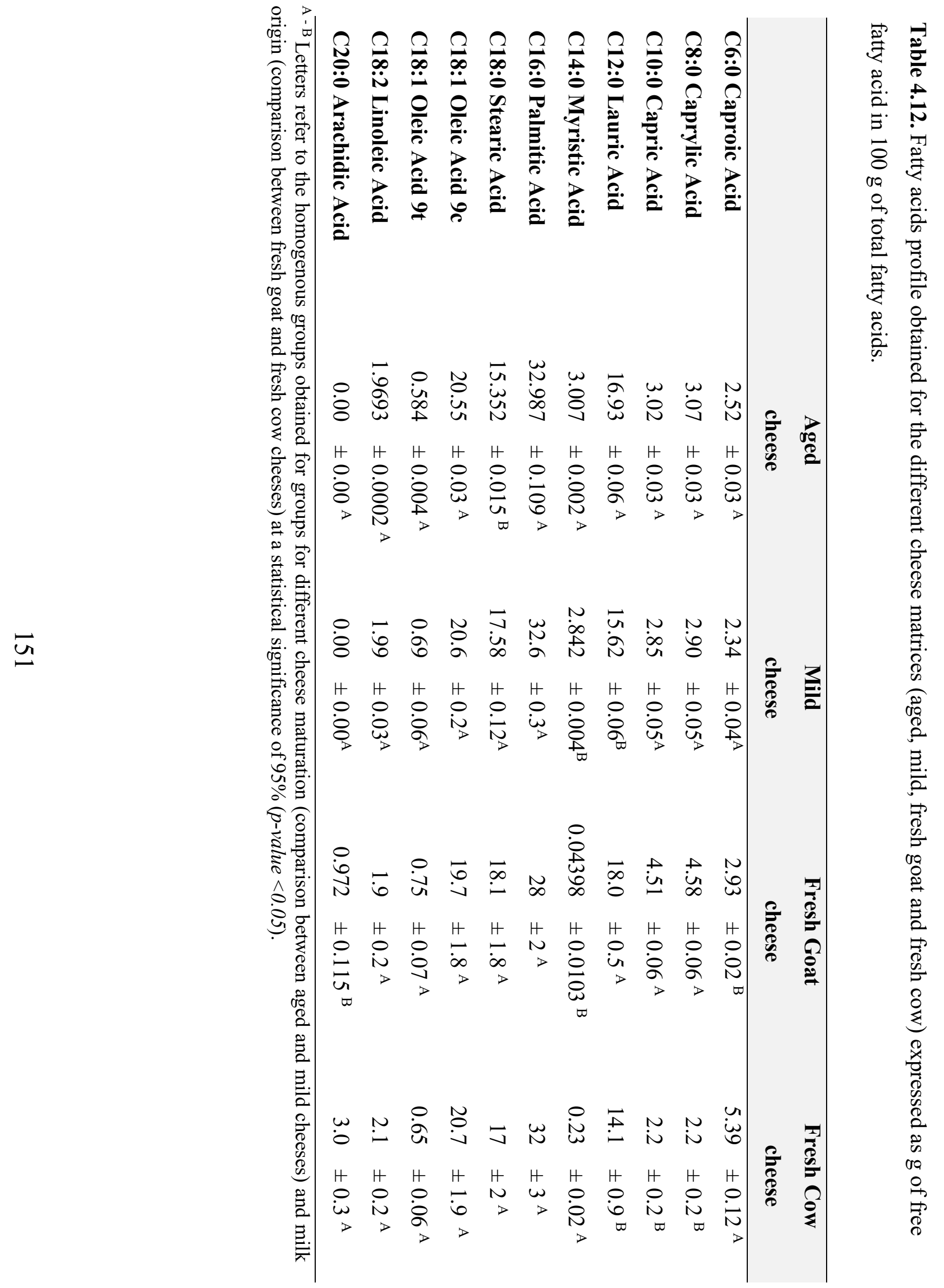


Regarding the influence of intestinal conditions on the FFA profile after digestion (Figure 4.9), the optimal conditions of pH 7 and bile $10 \mathrm{mmol} / \mathrm{L}$ slightly increased the FFA released compared to the EPI conditions. An exception of this tendency was the FFA found in the digested aged cheese, for which slightly higher contents of saturated and unsaturated medium-long-chain fatty acids $\left(\mathrm{C}_{16: 0,}, \mathrm{C}_{18: 0}, \mathrm{C}_{18: 1 \mathrm{c}}, \mathrm{C}_{18: 1 \mathrm{t}}\right.$ and $\left.\mathrm{C}_{20}\right)$ were found at $\mathrm{pH} 6$ and $1 \mathrm{mmol} / \mathrm{L}$ of bile salts. When comparing FFA profile of the four digested cheeses, one gram of digested fat of fresh goat cheese presented considerably higher quantities of all FFA than the same fat amount of fresh cow cheese. Likewise, the FFA profile of digested aged cheese was richer in all the identified FFA than mild cheese. These results again evidence the easier digestibility of fresh cheeses made from goat milk and cheeses subjected to long maturation time. Therefore, consumption of fresh goat and aged cheeses would be advisable for EPI patients with suboptimal intestinal conditions.

Concerning proteolysis, Table 4.13 shows the initial slope $\left(\Delta \mathrm{OD} / \mathrm{h}_{\text {initial }}\right)$ and the maximum protein hydrolysis $\left(\mathrm{OD}_{\max }\right)$ of the different cheeses digested under different intestinal conditions. $\mathrm{OD}_{\max }$ can be considered as an indicator of the proteolysis extent, while the initial slope $\left(\Delta \mathrm{OD} / \mathrm{h}_{\text {initial }}\right)$ refers to the kinetics of the initial proteolytic reactions (Bax, Aubry, Ferreira, Daudin, \& Gatellier, 2012). Both parameters were determined during and at the end of gastric and intestinal stages. Remarkably, all the studied cheeses presented similar protein content ( $\mathrm{g} / \mathrm{g}$ dry matter).

According to the obtained results, proteolysis resulting from gastric pepsin activity was higher in aged and fresh cow cheeses, and much lower than in the intestinal stage for all cheeses. The hydrolysis of protein achieved in fresh cow cheese is especially relevant because the Protease Units (PU)/g protein was lower for this cheese in comparison with the others. Other studies, however, showed that goat milk caseins were more efficiently digested compared to cow milk ones (Hodgkinson, Wallace, Boggs, Broadhurst, \& Prosser, 2018), in our study, gastric pepsin seemed to present more affinity for caseins of cow cheese than for other kind of cheeses. Bovine milk proteins are similar to those of goat milk, but they present different genetic polymorphisms. These 
differences are due to amino acids substitutions in protein chains, and lead to different digestibility fates (Haenlein, 2004).

On the other hand, higher proteolysis $\left(\mathrm{OD}_{\max }\right)$ was found at the end of gastrointestinal digestion for both ripened cheeses when compared to fresh ones, and particularly than in fresh goat cheese that was digested under similar PU/g protein, and thus comparable to the ripened ones. As previously mentioned, both, salting and ripening stages, favoured the proteolytic activity, giving as a result an increase of free amino acids and small peptides in ripened cheese, coming from casein degradation (McSweeney, 2004). As it was expected, $\mathrm{pH} 7$ instead of 6 promoted higher proteolysis extent. In fact, it is well-known that the optimal pancreatic proteases activity is around $\mathrm{pH}$ 7.5. However, neither intestinal $\mathrm{pH}$ nor bile concentration seemed to determine kinetics $\left(\Delta \mathrm{OD} / \mathrm{h}_{\text {initial }}\right)$ of the initial proteolytic reactions. 

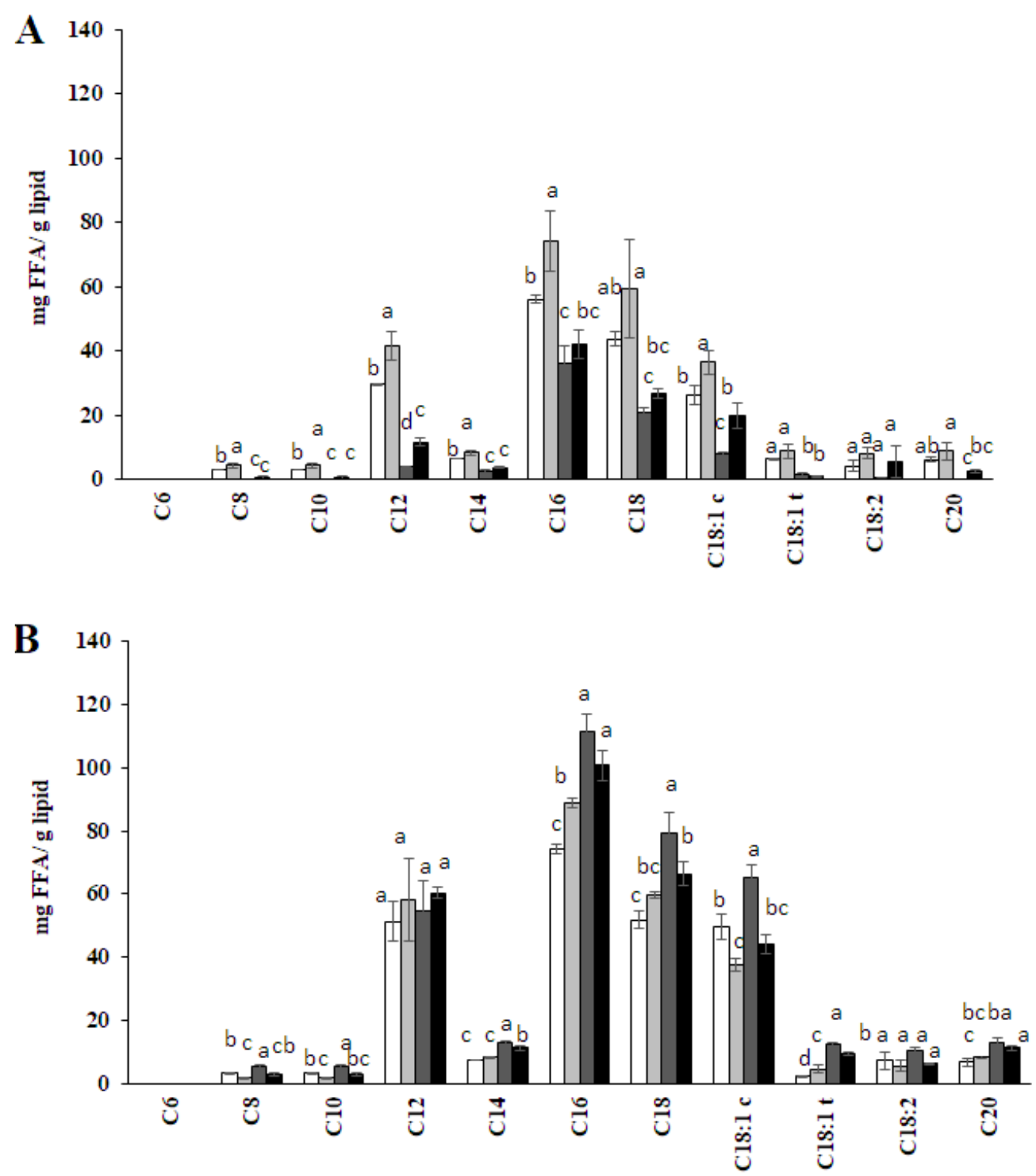

Figure 4.9. FFA profile of different cheese matrices after in vitro digestion simulating two intestinal scenarios corresponding to a healthy adult ( $\mathrm{pH} 7$ and bile $10 \mathrm{mmol} / \mathrm{L}$ ) and the most disadvantageous EPI conditions (pH 6 and bile $1 \mathrm{mmol} / \mathrm{L}$ ). A: pH 6 Bile $1 \mathrm{mmol} / \mathrm{L}$ fresh goat cheese $\square$; pH 6 Bile 1 mmol/L fresh cow cheese $\square$; pH 7 Bile 10 mmol/L fresh goat cheese $\square$; pH 7 Bile 10 mmol/L fresh cow cheese $\square$. B: pH 6 Bile 1 mmol/L mild cheese $\square$; pH 6 Bile 1 mmol/L aged cheese $\square$; pH 7 Bile 10 mmol/L mild cheese $\square$; pH 7 Bile 10 mmol/L aged cheese ${ }^{\mathrm{a}-\mathrm{c}}$ Letters refer to the homogenous groups obtained for different cheese (mild, aged, fresh cow and fresh goat cheeses) for the same fatty acid (C6, C8, C10, C12, C14, C16, C18, C18:1c, C18:1t, $\mathrm{C} 18: 2$ and $\mathrm{C} 20)$ and at a statistical significance of statistical significance of $95 \%$ (p-value $<0.05)$. 


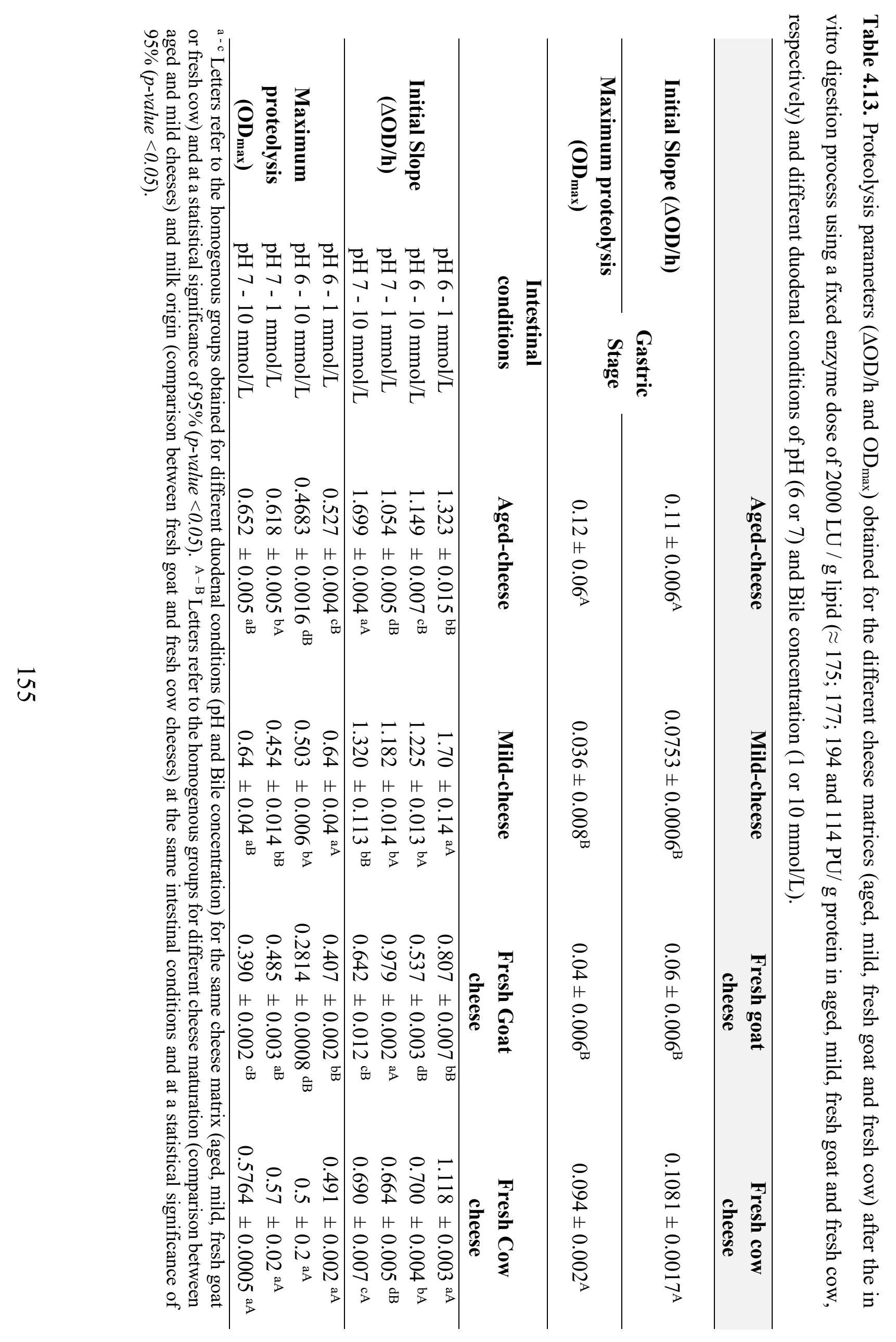




\subsection{Influence of oral pancreatic supplementation on macronutrients digestibility of different fresh and ripened cheeses}

The impact of the oral supplement dose on macronutrient digestibility was also assessed. Figure 4.6 shows the results of the MDI (\%) and lipolysis extent (\%) at different enzymatic dosages (1000-4000 LU/g lipid) and at EPI fixed intestinal conditions of pH 6 and bile concentration $1 \mathrm{mmol} / \mathrm{L}$. Table 4.14 gathers the results of proteolysis under the same conditions. As previously stated, MDI (\%) did not seem to depend on intestinal conditions (Table 4.11), but on cheese-related factors and especially of ripening. Similarly, the supplementation with pancreatin only increased MDI (\%) of digested fresh goat cheese, irrespective from the dosage. On the contrary, lipolysis extent (\%) was highly dependent on pancreatin dose, increasing gradually as long as it did. Figure 4.10 shows that fresh goat cheese reached the maximum value of lipolysis extent $(\approx 100 \%)$ at $2000 \mathrm{LU} / \mathrm{g}$ fat. Fresh cow cheese, in contrast, required a higher dose (4000 $\mathrm{LU} / \mathrm{g}$ fat) to reach a lipolysis extent of $\approx 65 \%$. In fact, fresh cow cheese, $100 \%$ made from cow milk, seemed to be the less digestible in terms of lipids. The difference might be due to the fat origin from milk (cow or goat). Goat milk presents higher concentration of short and medium chain fatty acids ( $\mathrm{C} 6$ to $\mathrm{C} 12)$ than cow milk. Consequently, this matrix allowed for greater release of free fatty acids. Some authors reported that goat milk has smaller fat globule size than cow milk, whereby led to greater rates of lipolysis in cheese made from goat milk (Ceballos et al., 2009; Logan et al., 2017; Park, 2001). Lower fat globule size leads to an increase of the total fat globules surface, apparently enhancing fat digestibility. Furthermore, aging time also affected lipolysis. The highest lipolysis extent in digested aged cheese $(\approx 80 \%)$ and digested mild cheese $(\approx 45 \%)$ was achieved at $2000 \mathrm{LU} / \mathrm{g}$ fat. In both cheeses, the increment of pancreatic dose above 2000 LU/g fat did not improve lipid digestibility. 

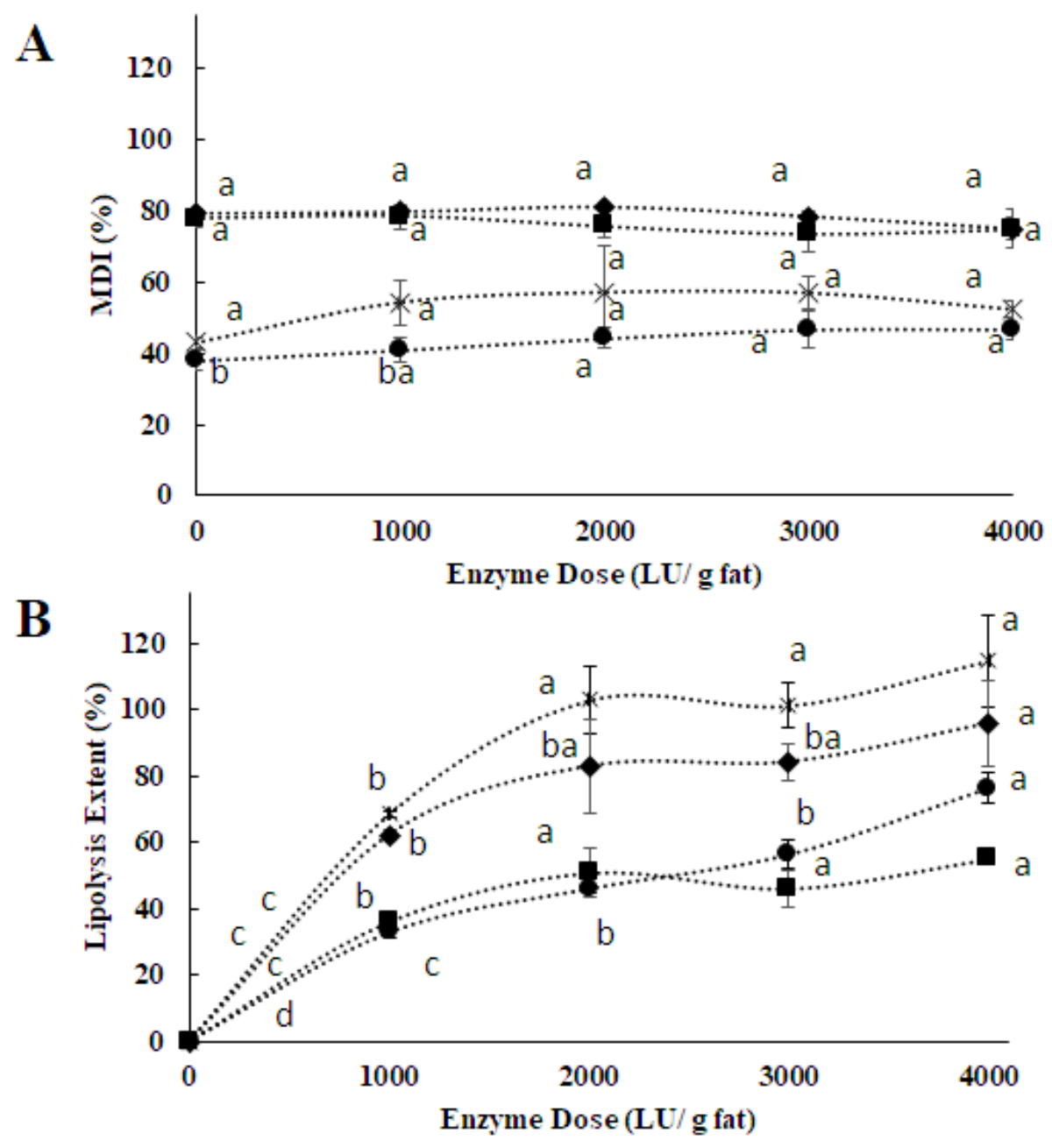

Figure 4.10. Matrix degradation index (\%) (A) and Lipolysis extent (\%) (B) obtained for the different cheese matrices (mild cheese $\mathbf{\bullet}$; aged cheese $\boldsymbol{\bullet}$; fresh cow cheese $\boldsymbol{\bullet}$; fresh goat cheese ${ }^{\circledR}$ ) after in vitro digestion at fixed duodenal conditions of $\mathrm{pH} 6$ and Bile concentration 1 $\mathrm{mmol} / \mathrm{L}$ using different doses of Kreon $(0-4000 \mathrm{LU} / \mathrm{g}$ fat $) .{ }^{\mathrm{a}-\mathrm{c}}$ Letters refer to the homogenous groups obtained for different doses $(0-4000)$ for the same cheese matrix (mild, aged, fresh cow and fresh goat cheeses) at a statistical significance of $95 \%$ ( $p$-value $<0.05)$.

As shown in Table 4.13, the initial kinetics of proteolysis was faster (higher values of initial slope) in cheeses subjected to maturation than in fresh ones, independently of the enzymatic supplement dosage. Small peptides and free amino acids resulting from proteolysis occurring during aging act as bio-catalysers, enhancing the 
kinetics of the further proteolysis during digestion (Tavano, 2013). Proteolysis occurred faster in fresh cow cheese than in fresh goat cheese, considering the results of initial slope at $2000 \mathrm{LU} / \mathrm{g}$ lipid (194 PU/g protein) in fresh goat cheese, and $3000 \mathrm{LU} / \mathrm{g}$ lipid (171 PU/g protein) in fresh cow. Overall, Table 4.13 illustrates that high doses of enzyme supplement seem to be associated with a reduction of the initial slope in aged and fresh cow cheeses. These results can validate the hypothesis that proteolysis extent decreases when a certain dose of enzyme supplement is present. Enzyme autoaggregation, over a certain limit of concentration, together with product inhibition, could leads to proteases inactivation. This second phenomenon could be especially relevant in in vitro static models of digestion because of products of proteolysis are not gradually removed from the system.

In terms of maximum proteolysis, similar values for fresh cheeses at the same $\mathrm{PU} / \mathrm{g}$ protein were found. On the other hand, the presence of pancreatic proteases was essential to accomplish casein hydrolysis during intestinal stage, but without significant relevance of the protease dose. During cheese manufacturing, rennet is added to milk causing casein hydrolysis and leaving milk serum free. As a result, an increase in the attractive forces is produced between micelles found in milk, resulting in the formation of casein aggregates that maintain fat globules and serum retained inside the protein matrix (McSweeney, 2004). The importance of protein hydrolysis and lipolysis during cheese processing should be considered since the resultant matrices of milk and cheese are completely different. 


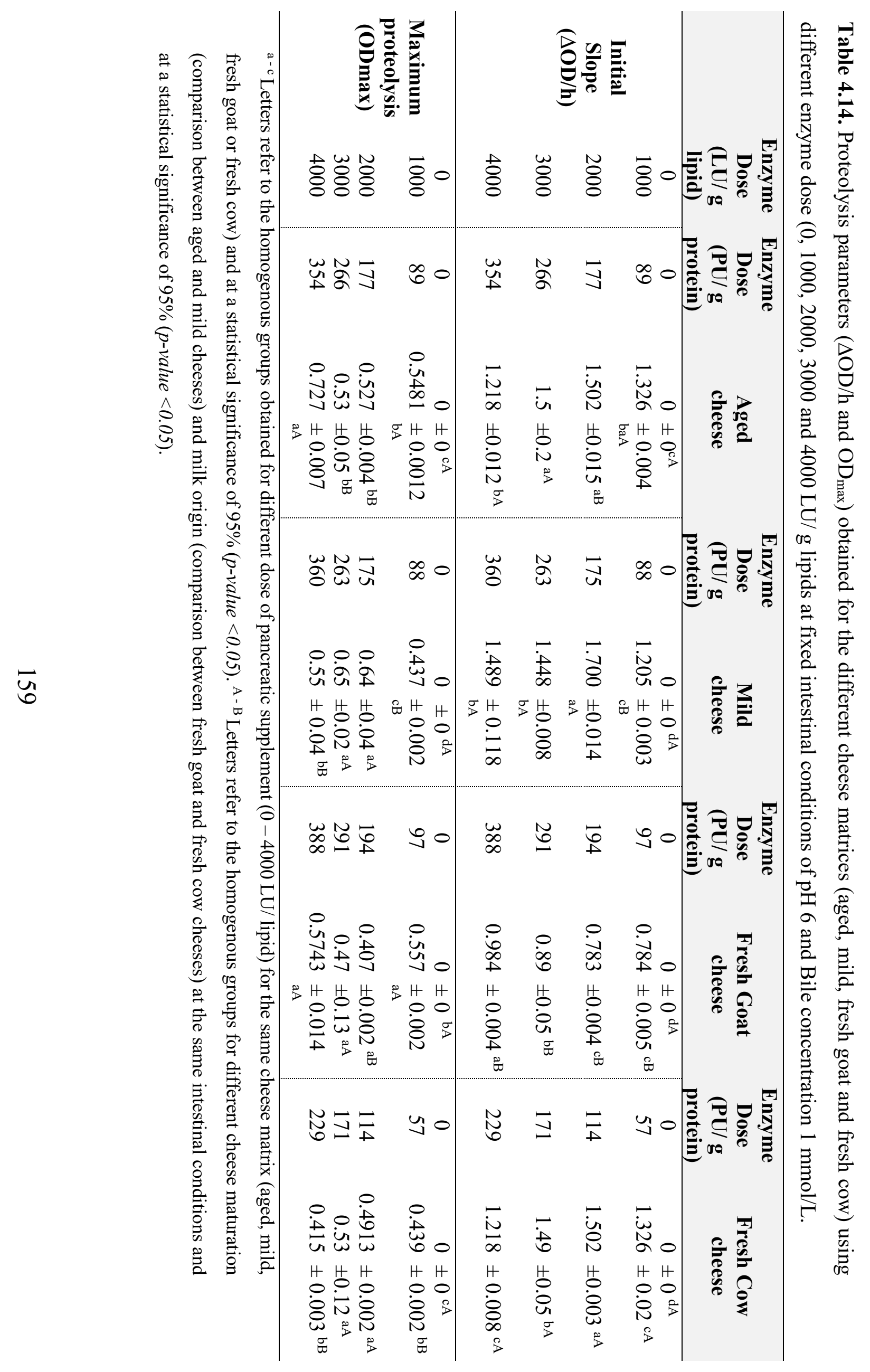




\section{CONCLUSIONS}

The present study points out that the type of cheese and together with the hostindividual gastrointestinal conditions influence lipids and proteins digestibility. Even if lipolysis was completed $(\approx 100 \%)$ for all cheeses under the healthy intestinal conditions; goat-fresh cheese and aged cheese achieved higher lipolysis extent under EPI conditions lipolysis than cow-fresh cheese and mild-cheese.

Concerning protein digestibility, it was only dependent on the characteristics of cheeses, being higher in fresh-cow cheeses and matured ones than in fresh-goat cheese. Results also demonstrate that some dairy matrix properties, milk origin and ripening time, greatly affect lipolysis in the EPI situation. Concretely, aged and fresh-goat cheeses reached the maximum value of lipolysis extent, $80 \%$ and $100 \% 100 \%$ respectively, at $2000 \mathrm{LU} / \mathrm{g}$ fat; whilst lipolysis remained incomplete in fresh-cow cheese and mildcheeses even at the highest dose of $4000 \mathrm{LU} / \mathrm{g}$ fat.

To conclude, this study has unveiled the implication of food characteristics and host-related factors on lipid and protein digestibility in cheese products. Our findings could contribute to establishing dietary recommendations for pancreatic insufficient patients, including the promotion of matured cheese consumption, as it would be the most easily digested.

\section{ACKNOWLEDGEMENTS}

Authors of this paper, on behalf of MyCyFAPP consortium, acknowledge the European Union and the Horizon 2020 Research and Innovation Framework Programme for funding the above-mentioned project under grant agreement number 643806 . The authors would like to thank the Conselleria de Educació i Investigació de la Generalitat Valenciana for the PhD scholarship given to Andrea Asensio Grau.

\section{REFERENCES}

AOAC (2000). Official methods of analysis of AOAC International. (17th ed.). Gaithersberg, Maryland: Association of Official Chemists.Agnihotri, M. K., \& Prasad, 
S. (1993). Biochemistry and processing of goat milk and milk products. Small Ruminant Research, 12, 151-170. https://doi.org/10.1016/0921-4488(93)90080-2

Alférez, M. J. M., Barrionuevo, M., López Aliaga, I., Sanz-Sampelayo, M. R., Lisbona, F., Robles, J. C., \& Campos, M. S. (2001). Digestive utilization of goat and cow milk fat in malabsorption syndrome. Journal of Dairy Research, 68(3), 451-461. https://doi.org/10.1017/S0022029901004903

Arora, R., Bhojak, N., \& Joshi, R. (2013). Comparative aspacts of goat and cow milk. Int. J. Engineering Sci. Invention, 2(1), 7-10.

Asensio-Grau, A., Peinado, I., Heredia, A., \& Andrés, A. (2018). Effect of cooking methods and intestinal conditions on lipolysis, proteolysis and xanthophylls bioaccessibility of eggs. Journal of Functional Foods, 46(May), 579-586. https://doi.org/10.1016/j.jff.2018.05.025

Ayala-Bribiesca, E., Lussier, M., Chabot, D., Turgeon, S. L., \& Britten, M. (2016). Effect of calcium enrichment of Cheddar cheese on its structure, in vitro digestion and lipid bioaccessibility. International Dairy Journal, 53, 1-9. https://doi.org/10.1016/j.idairyj.2015.09.002

Ayala-Bribiesca, E., Turgeon, S. L., \& Britten, M. (2017). Effect of calcium on fatty acid bioaccessibility during in vitro digestion of Cheddar-type cheeses prepared with different milk fat fractions. Journal of Dairy Science, 100(4), 2454-2470. https://doi.org/10.3168/jds.2016-11902

Bax, M., Aubry, L., Ferreira, C., Daudin, J., \& Gatellier, P. (2012). Cooking temperature is a key derminant of in vitro meat protein digestion rate: investigation of underlying mechanisms. https://doi.org/10.1021/jf205280y

Briefel, R. R., Reidy, K., Karwe, V., \& Devaney, B. (2004). Feeding Infants and Toddlers Study: Improvements needed in meeting infant feeding recommendations. Journal of the American Dietetic Association, 104(SUPPL. 1), 31-37. https://doi.org/10.1016/j.jada.2003.10.020

Calvo-Lerma, J., Fornés-Ferrer, V., Heredia, A., \& Andrés, A. (2018). In vitro digestion of lipids in real foods: influence of lipid organization within the food matrix and interactions with nonlipid components. In Vitro Digestion of Lipids in Real Foods: 
Influence of Lipid Organization Within the Food Matrix and Interactions with Nonlipid Components. Journal of Food Science, 83(10), 2629-2637. https://doi.org/10.1111/1750-3841.14343

Calvo-Lerma, J., Hulst, J., Boon, M., Martins, T., Ruperto, M., Colombo, C., ... Ribes-Koninckx, C. (2019). The relative contribution of food groups to macronutrient intake in children with cystic fibrosis: a european multicenter assessment. The Relative Contribution of Food Groups to Macronutrient Intake in Children with Cystic Fibrosis: A European Multicenter Assessment. Journal of the Academy of Nutrition and Dietetics. https://doi.org/10.1016/j.jand.2019.01.003

Carriere, F., Renou, C., Lopez, V., De Caro, J., Ferrato, F., Lengsfeld, H., ... Verger, R. (2000). The specific activities of human digestive lipases measured from the in vivo and in vitro lipolysis of test meals. Gastroenterology, 119(4), 949-960. https://doi.org/10.1053/gast.2000.18140

Ceballos, L. S., Morales, E. R., de la Torre Adarve, G., Castro, J. D., Martínez, L. P., \& Sampelayo, M. R. S. (2009). Composition of goat and cow milk produced under similar conditions and analyzed by identical methodology. Journal of Food Composition and Analysis, 22(4), 322-329. https://doi.org/10.1016/j.jfca.2008.10.020

Gelfond, D., Ma, C., Semler, J., \& Borowitz, D. (2013). Intestinal ph and gastrointestinal transit profiles in cystic fibrosis patients measured by wireless motility capsule. Digestive Diseases and Sciences, 58(8), 2275-2281. https://doi.org/10.1007/s10620-012-2209-1

González-Bacerio, J., Hernández, J. R., \& Martínez, A. D. M. (2010). Las lipasas: enzimas con potencial para el desarrollo de biocatalizadores inmovilizados por adsorción interfacial. Revista Colombiana de Biotecnología, 12(1), 124-140. Retrieved from ttp://www.revistas.unal.edu.co/index.php/biotecnologia/article/view/15574/38075

Haenlein, G. F. W. (2004). Goat milk in human nutrition. Small Ruminant Research, 51(2), 155-163. https://doi.org/10.1016/j.smallrumres.2003.08.010

Hodgkinson, A. J., Wallace, O. A. M., Boggs, I., Broadhurst, M., \& Prosser, C. G. (2018). Gastric digestion of cow and goat milk: Impact of infant and young child in 
vitro digestion conditions. Food Chemistry, 245(October 2017), 275-281. https://doi.org/10.1016/j.foodchem.2017.10.028

Hunter, J. E. (2001). Studies on Effects of Dietary Fatty Acids as Related to Their Position on Triglycerides, 36(7).

Hur, S. J., Lim, B. O., Decker, E. A., \& McClements, D. J. (2011). In vitro human digestion models for food applications. Food Chemistry, 125(1), 1-12. https://doi.org/10.1016/j.foodchem.2010.08.036

Karaman, A. D., \& Akalin, A. S. (2013). Improving quality characteristics of reduced and low fat Turkish white cheeses using homogenized cream. LWT - Food Science and Technology, 50(2), 503-510. https://doi.org/10.1016/j.lwt.2012.08.017

Lamothe, S., Azimy, N., \& Bazinet, L. (2014). Function Interaction of green tea polyphenols with dairy matrices in a simulated gastrointestinal environment. Food \& Function, 5, 2621-2631. https://doi.org/10.1039/C4FO00203B

Lamothe, S., Corbeil, M.-M., Turgeon, S. L., \& Britten, M. (2012). Influence of cheese matrix on lipid digestion in a simulated gastro-intestinal environment. Food \& Function, 3(7), 724. https://doi.org/10.1039/c2fo10256k

Logan, A., Xu, M., Day, L., Singh, T., Moore, S. C., Mazzonetto, M., \& Augustin, M. A. (2017). Milk fat globule size affects Cheddar cheese properties. International Dairy Journal, 70, 46-54. https://doi.org/10.1016/j.idairyj.2016.11.003

Maldonado-Valderrama, J., Wilde, P., MacIerzanka, A., \& MacKie, A. (2011). The role of bile salts in digestion. Advances in Colloid and Interface Science, 165(1), 36-46. https://doi.org/10.1016/j.cis.2010.12.002

McSweeney, P. L. H. (2004). Biochemistry of cheese ripening: Introduction and overview. Cheese: Chemistry, Physics and Microbiology, 1(C), 347-360. https://doi.org/10.1016/S1874-558X(04)80073-3

Minekus, M., Alminger, M., Alvito, P., Ballance, S., Bohn, T., Bourlieu, C., ... Brodkorb, A. (2014). A standardised static in vitro digestion method suitable for food an international consensus. Food Funct. Food Funct, 5(5), 1113-1124. https://doi.org/10.1039/c3fo60702j 
Park, Y. W. (2001). Proteolysis and lipolysis of Goat's milk cheese. Journal of Dairy Science, 84(E. Suppl.), E84-E92. https://doi.org/10.3168/jds.S00220302(01)70202-0

Pastorino, A. J., Hansen, C. L., \& McMahon, D. J. (2003). Effect of salt on structure-function relationships of cheese. Journal of Dairy Science, 86(1), 60-69. https://doi.org/10.3168/jds.S0022-0302(03)73584-X

Paz-Yépez, C., Peinado, I., Heredia, A., \& Andrés, A. (2018). Influence of particle size and intestinal conditions on in vitro lipid and protein digestibility of walnuts and peanuts. Food Research International, 119(June 2018), 951-959. https://doi.org/10.1016/j.foodres.2018.11.014

Prazeres, D. M. F., Garcia, F. A. P., \& Cabral, M. S. (1994). Continous lipolysis in a reversed micellar membrane bioreactor. Bioprocess Engineering, Bi0pr0cess Engineering Continuous iipolysis in a reversed micellar membrane bioreactor, 10(1), $21-27$.

Rodríguez-Alcalá, L. M., Harte, F., \& Fontecha, J. (2009). Fatty acid profile and CLA isomers content of cow, ewe and goat milks processed by high pressure homogenization. Innovative Food Science and Emerging Technologies, 10(1), 32-36. https://doi.org/10.1016/j.ifset.2008.10.003

Seksik, P., Rainteau, D., Wolf, C., Humbert, L., Laugier, R., Tuvignon, N., \& Carrière, F. (2018). Postprandial bile acid levels in intestine and plasma reveal altered biliary circulation in chronic pancreatitis patients. Journal of Lipid Research, 59(11), 2202-2213. https://doi.org/10.1194/jlr.m084830

Shani-Levi, C., Alvito, P., Andrés, A., Assunção, R., Barberá, R., Blanquet-Diot, S., ... Lesmes, U. (2017). Extending in vitro digestion models to specific human populations: Perspectives, practical tools and bio-relevant information. Trends in Food Science and Technology, 60, 52-63. https://doi.org/10.1016/j.tifs.2016.10.017

Tavano, O. L. (2013). Protein hydrolysis using proteases: An important tool for food biotechnology. Journal of Molecular Catalysis B: Enzymatic, 90, 1-11. https://doi.org/10.1016/j.molcatb.2013.01.011 
Turck, D., Braegger, C. P., Colombo, C., Declercq, D., Morton, A., Pancheva, R., ... Wilschanski, M. (2016). ESPEN-ESPGHAN-ECFS guidelines on nutrition care for infants , children, and adults with cystic fi brosis. Clinical Nutrition, 35(3), 557577. https://doi.org/10.1016/j.clnu.2016.03.004

Walther, B., Schmid, A., Sieber, R., \& Wehrmüller, K. (2008). Cheese in nutrition and health. Dairy Science and Technology, 88(4-5), 389-405. https://doi.org/10.1051/dst:2008012

Weaver, C. M., \& Heaney, R. P. (2005). Modern Nutrition in Health and Disease. Modern Nutrition in Health and Disease, (October).

Whitcomb, D. C., Lehman, G. A., Vasileva, G., Malecka-Panas, E., Gubergrits, N., Shen, Y., ... Caras, S. (2010). Pancrelipase delayed-release capsules (CREON) for exocrine pancreatic insufficiency due to chronic pancreatitis or pancreatic surgery: A double-blind randomized trial. American Journal of Gastroenterology, 105(10), 22762286. https://doi.org/10.1038/ajg.2010.201

Yaich, H., Garna, H., Besbes, S., Paquot, M., Blecker, C., \& Attia, H. (2011). Chemical composition and functional properties of Ulva lactucaUlva lactuca seaweed collected in Tunisia. Food Chemistry, 128(4), 895-901. https://doi.org/10.1016/j.foodchem.2011.03.114 


\section{CHAPTER 4}

\section{INFLUENCE OF PROCESSING AND INTESTINAL CONDITIONS ON MACRONUTRIENTS DIGESTIBILITY OF SALMON}

The last chapter of the thesis deals with the study of macronutrients digestibility in salmon, representing the major dietary intake of fat from the fish food group. There are different oily fish such as herring, sardines, pilchards, sprats and trout. However, these species contain lower amount of fat compared to salmon. Moreover, salmon is the most frequently consumed blue fish among children with $\mathrm{CF}$ and presents a healthy fatty acid profile (high in polyunsaturated fat, and particularly omega-3 fatty acids), justifying the interest of focusing the study in this fish. As other types of blue fish, salmon is composed mainly by protein and lipids, this characteristic being shared with the other animal-origin foods reported in the previous chapters. Following a similar approach than in the egg study, a single food was studied, to which different culinary preparations were applied, in order to evidence possible food matrix effects related to the household processing. In this regard, the most frequent ways of consuming salmon were targeted: raw, marinated and cooked.

To achieve this goal, samples were submitted in an in vitro digestion and afterwards, centrifugate and filtrate to separate the liquid fraction (bioaccessible) from the solid particles. In accordance to previous chapters, the analytical determinations regarding digestibility included the matrix degradation index, lipolysis and proteolysis. Matrix degradation index was estimated from the solid particles dispersed after digestion. TCA soluble protein and lipolysis with the free fatty acids enzymatic kit were measured in the bioaccessible fraction. In this study, in addition, lipolysis was measured by means of nuclear magnetic resonance (NMR) in whole digested sample, which allows for the identification of the lipidic species, including: triglycerides (whole molecule, undigested) and the species resulting from partial (diglycerides) or total hydrolysis (monoglycerides and free fatty acids). The study also included a statistical analysis to 
determine the effect of food matrix processing and the intestinal conditions on proteolysis and lipolysis.

The results of this study provide a thorough characterisation of digestibility of salmon macronutrients (lipids and protein) as conditioned by processing and intestinal conditions. In the situation of standard healthy intestinal conditions, proteolysis was not largely affected by processing. Lipid digestibility, however, improved when salmon was cooked, marinated process resulting in the lowest lipolysis extent. Nonetheless, the altered intestinal conditions negatively affected both salmon proteolysis and lipolysis, specifically the combination of low $\mathrm{pH}(6)$ and low bile salts concentration $(1 \mathrm{mM})$ corresponding to the most adverse intestinal scenario of $\mathrm{CF}$ and pancreatic insufficiency. The reduced $\mathrm{pH}$ and bile salts concentration also promoted decreased 1,2-DG and FA release, thus representing a drawback for lipolysis. Overall, the culinary preparation had a major effect on proteolysis, while the intestinal conditions were the most determinants of lipolysis. Besides, in this study the comparison of lipolysis as determined by two different methodologies was enabled, results showing equivalent values of lipolysis. The results also confirmed that the concentration of pancreatin did not have an effect on proteolysis, being $2000 \mathrm{LU} / \mathrm{g}$ lipid the optimal concentration to reach the highest proteolysis under both possible intestinal scenarios related to $\mathrm{CF}$ and pancreatic insufficiency. Only marinated salmon increased lipolysis when moving from 2000 to $4000 \mathrm{LU} / \mathrm{g}$ fat, but not changing if the dose increased to $6000 \mathrm{LU} / \mathrm{g}$ fat. Despite of increasing pancreatin concentration under both altered intestinal scenarios, lipolysis extent did not reach values above of $60 \%$ in the case of cooked salmon and the maximum pancreatin concentration. Focusing on the simulation at the standard healthy intestinal conditions, fat digestion, would not either fulfil complete lipolysis, and around $80 \%$ would be the expected extent. According to the goal of the project, the optimal dose that maximise lipolysis in the different salmon preparations was targeted. Cooked salmon reached the highest lipolysis (50\%) at $2000 \mathrm{LU} / \mathrm{g}$ lipid, marinated reached at $3000 \mathrm{LU} / \mathrm{g}$ lipid a lipolysis extent of $46 \%$, and the optimal dose in the raw counterpart would be $6000 \mathrm{LU} / \mathrm{g}$ lipid to obtain a $49 \%$ of lipolysis. 
Therefore, in practical terms, and considering the increase from 2000 to $4000 \mathrm{LU} / \mathrm{g}$ fat only accounts for minor increase of lipolysis in cooked salmon, $2000 \mathrm{LU} / \mathrm{g}$ lipid would be the recommended pancreatin supply when salmon is consumed in the context of CF and pancreatic insufficiency. 


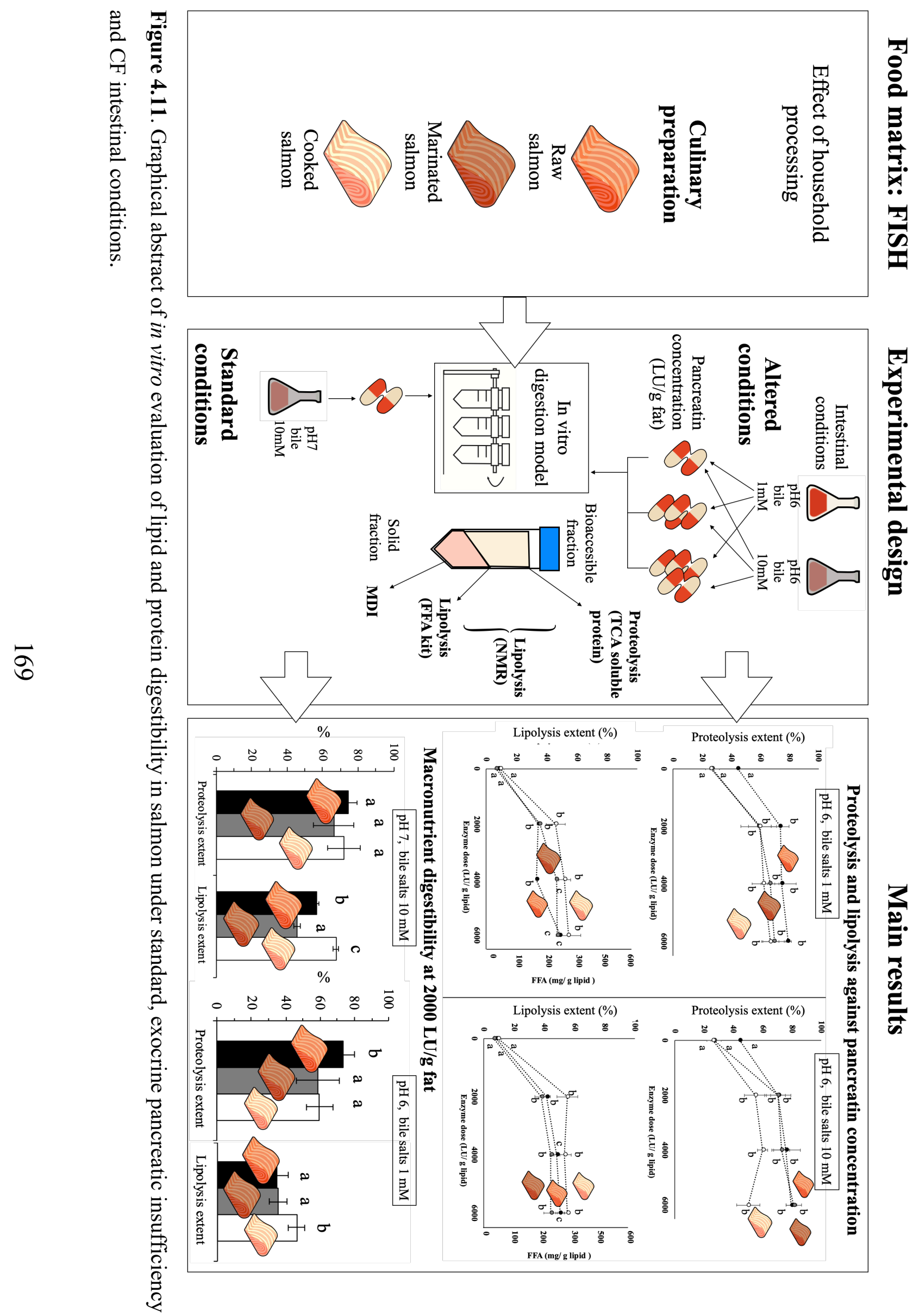


Title: In vitro digestion of salmon: influence of processing and intestinal conditions on macronutrients digestibility

Andrea Asensio-Grau, Joaquim Calvo-Lerma, Ana Heredia and Ana Andrés

Food Chemistry, article in press.

\title{
https://doi.org/10.1016/j.foodchem.2020.128387
}

\begin{abstract}
Salmon is the main dietary source of omega-3 lipids and contains high-biological value protein. However, processing techniques could affect macronutrient digestibility. Also, altered intestinal conditions, particularly given in pancreatic insufficiency, could threaten digestibility. This study tested both hypotheses by subjecting raw, marinated and microwave-cooked salmon to static in vitro digestion under healthy $(\mathrm{pH} 7$, bile concentration $10 \mathrm{mM})$ and altered $(\mathrm{pH} 6$, bile 1 or $10 \mathrm{mM})$ intestinal conditions with different pancreatin concentrations. In the standard conditions, proteolysis was not affected by processing, but lipolysis decreased in marinated (46\%) and raw salmon $(57 \%)$ compared to the cooked matrix (67\%). In altered conditions, proteolysis and lipolysis decreased to different extents depending on the treatment. Overall, processing affected proteolysis the most (f-ratio=5.86), while intestinal conditions were the major determinants of lipolysis ( $\mathrm{f}$-ratio=58.01). This study could set the ground to establish dietary recommendations of salmon for specific population groups.
\end{abstract}

Keywords: pancreatic insufficiency; lipolysis; proteolysis; salmon, processing 


\section{INTRODUCTION}

In the last decade, oily fish consumption has increased due to the awareness raised on their beneficial effects in health. Oily fish contains high biological value protein and polyunsaturated fatty acids (PUFA), which contribute to reduced risk of obesity, inflammatory and cardiovascular diseases and hypertension (Cohen et al., 2005; Hosomi, Yoshida \& Fukunaga, 2012). PUFAs are the most important fatty acids (FA) since their dietary sources are limited to not so frequently consumed foods, and they exert relevant for physiological functions. For these reasons, the World Health Organisation recommends that PUFA intake should be $10 \%$ of the daily energy intake. Additionally, a balanced omega-6:omega-3 ratio (close to 1:1) is advised in order to prevent from inflammatory status and development of diseases such as obesity and cancer. However, current dietary patterns situate the ratio in 20:1 due to the rare intake of fish among other sources of omega-3 (Simopoulos, 2016). In this sense, salmon is of special interest as compared to other fishery products, contains higher contents of omega-3 fatty acids, particularly eicosapentaenoic acid (EPA) and docosahexaenoic acid (DHA). When absorbed, these fatty acids are transformed in bioactive compounds with cytoprotective and anti-inflammatory activities, either via generation of antiinflammatory products (e.g. resolvins) or by blocking inflammatory agents. Thus, EPA and DHA contribute to the prevention and treatment of numerous diseases, especially those in which inflammation plays a relevant role (Calder, 2006). Altogether, regular consumption of salmon contributes to reach the recommended PUFA intake and to balance the desirable ratio.

Although salmon can be consumed raw in some culinary preparations, it is usually subjected to processing, such as-thermal treatments (baking, boiling, frying, etc.), smoking, marinating or salting. Foods subjected to certain heat treatments (boiling, baking, etc.) result in different sensorial and structural properties and a loss of water, which finally concentrates other components such as fat, proteins or minerals. In addition, the reduction or degradation of thermolabile compounds is accounted, including vitamins and carotenoids (Gladyshev, Sushchik, Gubanenko, Demirchieva \& Kalachova, 2006). Marinating and salting, on the other hand, imply salt and sugar 
penetration into the raw muscle, causing salt-driven protein denaturalisation together with considerable loss of muscle water, resulting in decreased fillet weight (LaubEkgreen, Martinez-Lopez, Frosch \& Jessen, 2018). Marinating is usually an artisanal process, and the conditions of the technique vary regionally. For example, LarrazábalFuentes, Escriche-Roberto \& Camacho-Vidal (2009) described marinating as the application of a mix of salt and sugar for 5-72 hours at $5{ }^{\circ} \mathrm{C}$. In turn, gastronomy globalisation has triggered the consumption of raw fish beyond Japan or Peru, the countries where raw fish, such as sushi or ceviche, have been traditionally consumed for centuries. Therefore, assessing nutrient digestibility in different salmon preparations raises as a relevant research question, as background knowledge suggests that protein and lipid digestibility could be affected by processing (Asensio-Grau, Peinado, Heredia \& Andrés, 2018; Asensio-Grau, Calvo-Lerma, Heredia \& Andrés, 2019 (a); AsensioGrau, Peinado, Heredia \& Andrés (b)).

On the other hand, apart from the possible impact of food processing on nutrient digestibility, the luminal gastrointestinal alterations (such as digestive fluids composition, intestinal $\mathrm{pH}$, etc.) could play an additional relevant role on digestibility (Calvo-Lerma, Fornés-Ferrer, Heredia \& Andrés, 2019). In this sense, lipid digestion is the most compromised hydrolytic phenomenon when pancreatic function alterations are present (such as in exocrine pancreatic insufficiency (EPI)), as the main lipase activity comes from pancreatin secreted by this organ. Altered pancreatic function causes decreased pancreatin and bicarbonate secretions, which results in reduced $\mathrm{pH}$ in the intestinal medium. This fact, together with a reduced bile secretion, which is also possible in some individuals suffering EPI, results in suboptimal intestinal conditions (Sarkar, Ye \& Singh, 2016; Maldonado-Valderrama, Wilde, Macierzanka \& Mackie, 2011). In this scenario, compositional and/or structural changes in food resulting from processing can be determinants of the lipolysis extent during digestion, some structures having proved to be more accessible to lipase than others (Calvo-Lerma, Fornés-Ferrer, Heredia \& Andrés, 2018). Individuals suffering EPI need pancreatin oral supplements to enable lipolysis (namely pancreatic enzyme replacement therapy). Up to now, there is low evidence to establish a dosing criterion of the supplements (Calvo-Lerma, Martínez- 
Barona, Masip, Fornés, \& Ribes-Koninckx, 2017), but recent studies suggest that food processing can be used for modulating intestinal lipolysis (Guo, Ye, Bellissimo, Singh \& Rousseau, 2017).

In this context, the aim of the present study was to assess, by means of a static in vitro digestion model, the impact of salmon processing (raw, marinating and microwave-cooking) against different settings of intestinal conditions and pancreatin concentration, on lipid and protein digestibility.

\section{MATERIALS AND METHODS}

\subsection{Sample preparation}

Three salmon specimens were purchased at a local supermarket from the same batch. On the same day of the acquisition, head, spines and tail were removed, leaving aside the completely clean fillets. Then, from each salmon specimen, fillets were separated in three sets and frozen $\left(-20^{\circ} \mathrm{C}\right)$ in order to preserve the same starting batch of salmon for

all the subsequent determinations. One set was cooked using a microwave oven (Samsung GW72N) at $2.25 \mathrm{~W} / \mathrm{g}$ for 4 minutes. The second set was marinated according to Larrazábal-Fuentes et al., (2009). For this purpose, a mixture of $50 \mathrm{~g}$ of salt and $50 \mathrm{~g}$ of sugar was added to $100 \mathrm{~g}$ of salmon in 1:1 (w/w) ratio. The fillets were covered with the mixture and wrapped with parafilm during 9 hours in refrigeration $\left(5^{\circ} \mathrm{C}\right)$. Then, salmon was rinsed with water and dried with a paper towel to remove the excess water. The third set was not processed to assess digestibility in thawed raw salmon.

\subsection{Materials}

For the preparation of the simulated digestive fluids the following reagents were used: $\mathrm{KCl}, \mathrm{KH}_{2} \mathrm{PO}_{4}, \mathrm{NaCl}, \mathrm{NaHCO}_{3}, \mathrm{MgCl}_{2}\left(\mathrm{H}_{2} \mathrm{O}\right)_{6},\left(\mathrm{NH}_{4}\right)_{2} \mathrm{CO}_{3}, \mathrm{CaCl}_{2}$, pepsin from porcine gastric mucosa ( $\geq 2500 \mathrm{U} / \mathrm{mg}$ protein) and bovine bile extract all of them from Sigma-Aldrich Chemical Company (St Louis, MO, USA).

A commercial pancreatic enzyme supplement (Kreon 10000 LU, Mylan) was used to study the impact of the pancreatin concentration. Each capsule contains $150 \mathrm{mg}$ of gastro-resistant microspheres that include porcine pancreatic enzyme equivalent to 10,000 lipase units, 8,000 amylase units, and 600 protease units. 
For the analytical determinations, the following products were required: TritonX $100 \%$, trichloroacetic acid (TCA), dichloromethane and deuterated chloroform. All were acquired from Sigma-Aldrich Chemical Company (St Louis, MO, USA), while ethanol (96\% v/v for analysis), $\mathrm{NaOH}$ and $\mathrm{HCl}$, were from AppliChemPanreac.

\subsection{Experimental design}

The experimental design consisted in two sets of experiments. In the first one, the influence of different combinations of intestinal $\mathrm{pH}$ and bile salts concentration $(\mathrm{pH} 6-$ $1 \mathrm{mM}$, pH $6-10 \mathrm{mM}$ and $\mathrm{pH} 7-10 \mathrm{mM}$ ) were simulated to evaluate lipolysis and proteolysis under a fixed pancreatin concentration (2000 LU/g lipid). The intestinal conditions of $\mathrm{pH} 7$ and bile salts concentration $10 \mathrm{mM}$ was selected as control, or standard conditions, as they have been agreed as the standard intestinal conditions of a healthy adult (Humbert et al., 2018), whereas the conditions of $\mathrm{pH} 6$ and bile salts concentration 1 or $10 \mathrm{mM}$ would represent two possible altered or suboptimal situations typically present in EPI (Humbert et al., 2018; Gelfond 2013). In the second set of experiments, different concentration of pancreatin (2000, 4000 and $6000 \mathrm{LU} / \mathrm{g}$ lipid) were used to assess the influence of this concentration in the intestinal stage of digestion on lipolysis and proteolysis under two suboptimal intestinal scenarios $(\mathrm{pH} 6-1 \mathrm{mM}$ and $\mathrm{pH} 6-10 \mathrm{mM})$. The selection of the studied range of pancreatin concentration was based on the current clinical recommendations of pancreatic enzyme supplementation in pancreatic insufficiency (Turck et al., 2016) which recommend a dose range between 2000 and $4000 \mathrm{LU} / \mathrm{g}$ fat. In addition, we assessed the $6000 \mathrm{LU} / \mathrm{g}$ fat as complete lipid hydrolysis was not reached with the referred pancreatin concentrations. In both experimental sets, the three preparations of salmon were tested. All experiments were performed at least in triplicate.

\subsection{In vitro digestion}

To assess the impact of altered intestinal conditions, in vitro digestion was carried out according to Asensio-Grau, Peinado, Heredia, \& Andrés, 2018. Simulated digestion fluids (SSF, salivary; SGF, gastric; and SIF, intestinal) were prepared from the 
corresponding stock solutions according to Brodkorb et al., 2019. The lipase (29.2 \pm 3.9 $\mathrm{U} / \mathrm{mg})$ and protease (trypsin $(0.96 \pm 0.08 \mathrm{U} / \mathrm{mg})$ and chymotrypsin $(0.24 \pm 0.05 \mathrm{U} / \mathrm{mg}))$ activities in pancreatin were tested prior to digestion in each experiment according to the protocol published by Brodkorb et al., 2019. The in vitro digestion process was simulated in three stages: For the oral stage, $\mathrm{SSF}(\mathrm{pH} 7)$ was added in at 1:1 proportion (w/v) and properly homogenized using a kitchen blender for 30 seconds (Vario Mixer, Ufesa 600 W) until obtaining an equivalent consistency to tomato paste (Minekus et al., 2014). The gastric stage continued by the incorporation of the $\mathrm{SGF}(\mathrm{pH} 3)$, containing gastric pepsin $(2000 \mathrm{U} / \mathrm{mL})$, to the oral bolus in 1:1 proportion $(\mathrm{v} / \mathrm{v})$, and tubes were head-over-heels rotated at $55 \mathrm{rpm}$ for 2 hours at $37{ }^{\circ} \mathrm{C}$ in an incubator chamber (JP Selecta SA, Barcelona). Afterwards, the pancreatic enzyme supplement in the concentration of 0 , 2000,4000 or $6000 \mathrm{LU} / \mathrm{g}$ lipid, was added to mimic the in vivo intake. The corresponding protease concentrations were $0,44,88$ and $132 \mathrm{PU} / \mathrm{g}$ protein in raw salmon, $0,70,140$ and $210 \mathrm{PU} / \mathrm{g}$ protein in marinated salmon and $0,43,87$ and $130 \mathrm{PU} / \mathrm{g}$ protein in cooked salmon. The supplement is directly swallowed without mastication and its gastroresistant coating is thereafter degraded at the intestinal stage due to the $\mathrm{pH}$ increase. Finally, the intestinal stage was simulated by adding the SIF ( $\mathrm{pH} 6$ or 7 ) and bile salts solution (bovine bile, 1 or $10 \mathrm{mM}$ ) to the gastric chyme in a $1: 1$ proportion $(\mathrm{v} / \mathrm{v})$, and tubes remained in agitation during $2 \mathrm{~h}$ at $37^{\circ} \mathrm{C}$ as in the gastric stage. During all the in vitro digestion process, $\mathrm{pH}$ was controlled to keep the experimental conditions of each set.

\subsection{Analytical determinations}

\subsubsection{Sample characterization}

Fat, water and protein content were determined in raw, marinated and cooked salmon by following the official methods (AOAC, 2000). Water activity $\left(a_{w}\right)$ was measured for raw, marinated and cooked salmon by CX-2 AQUALab (Decagon Devices, Inc., Pullman, WA). All determinations were performed in triplicate. 


\subsubsection{Matrix Degradation Index (MDI (\%))}

Matrix degradation Index (\%) was estimated by considering the proportion of dispersed solids in the digested fluid at the end of the intestinal stage Lamothe, Azimy $\&$ Bazinet, 2014). The total content of the digestion tubes was centrifuged (4000 x gforce 20 minutes, $\left.4{ }^{\circ} \mathrm{C}\right)$ and then filtered on a metallic sieve (1.6 $\mathrm{mm} \times 1.6 \mathrm{~mm}$ mesh) to separate the solid fraction. The liquid fraction was used for lipolysis and proteolysis extent determinations. To determine the mass of the solid large particles, the solid fraction of digesta was placed in a force-air oven at $60{ }^{\circ} \mathrm{C}$ for 48 hours until reaching constant weight. MDI (\%) was expressed as grams of solid large particles in 100 grams of total solid fraction in salmon.

\subsubsection{Proteolysis extent}

The extent of proteolysis was determined by measuring the soluble protein fraction in TCA (Lamothe et al., 2014). TCA was added to the liquid fraction from digested samples to a final concentration of $12 \%(\mathrm{w} / \mathrm{w})$. The mixture was vortexed, incubated for 15 min and filtered using a Whatman $n^{\circ} .40$ filter paper. The soluble fraction in 12\% TCA is composed of small peptides and amino acid residues. The filtrate was diluted in buffer (50 mM EDTA, $8 \mathrm{M}$ urea, $\mathrm{pH} 10)$ and protein was determined by measuring absorbance at $280 \mathrm{~nm}$ against a prepared blank with appropriate digestion fluids. Bovine Serum Albumin (BSA) was used for the quantification and proteolysis extent (\%), expressed as grams of soluble TCA protein in 100 grams of initial protein in raw, marinated or cooked salmon.

2.4.4 Lipolysis extent

\section{Enzymatic kit assay}

Lipolysis was determined as free fatty acids at the end of intestinal stage in all the simulated sets of intestinal conditions. Aliquots from the liquid fraction of digested samples were 100-fold diluted with a solution made with 5.6\% Triton X-100 and 6\% ethanol in water. This solution was used to both solubilize the free fatty acids and to stop lipolysis reaction. The amount of free fatty acids at the end of digestion was quantified using a free fatty acid colorimetric assay kit (Roche Diagnostics, Indianapolis, IN, USA) and the absorbance was measured with a spectrophotometer (UV/vis, Beckman Coulter) 
at wavelength of $546 \mathrm{~nm}$ (Lamothe et al., 2014). Docosahexaenoic acid standard was used for quantitative determination of free fatty acids (FFA) in salmon. Lipolysis extent (\%) was expressed as grams of hydrolysed TG in 100 grams of initial TG in raw, marinated or cooked salmon. For calculations, it was considered that one molecule of triacylglycerol results into the release of two fatty acids molecules and one monoacylglycerol (Hunter, 2001).

Nuclear Magnetic Resonance (NMR)

Lipidic fraction of undigested (raw, marinated and cooked salmon) and digested salmon in the different intestinal scenarios were analysed by $\mathrm{H}^{1}$ NMR. Lipid extraction, spectra acquisition and quantification of lipolytic products were conducted according to Nieva-Echevarría, Goicoechea, Manzanos \& Guillén (2015). The number of moles of each molecule was calculated considering acyl groups by the previously validated equations by Nieva-Echevarría, Goicoechea, Manzanos \& Guillén (2014). The NMR technique allows for quantifying triglycerides, partial triglycerides (monoglycerides and diglycerides) and free fatty acids. From a the physiological point of view, the lipid bioaccessible fraction can be estimated considering fatty acids and monoglycerides.

\subsection{Statistical analyses}

In order to study the significance of the differences of the factors (processing, intestinal conditions and pancreatin concentration) on each study variable (MDI, proteolysis and lipolysis), an unifactorial analysis of variance (ANOVA) was performed using Statgraphics Centurion XVII software with a confidence level of $95 \%$ (p-value $\leq 0.05$ ). Moreover, a multifactor analysis of variance (multivariate ANOVA) was also performed with a confident interval of $99 \%(p<0.001)$ and $95 \%(p<0.05)$ to know which factor (intestinal conditions or processing) affected the response variables (MDI, proteolysis and lipolysis) the most (F-ratio). The higher F-ratio value is directly proportional to the statistical effect of each factor on the response variables. The multifactor ANOVA was only applied to the results obtained at a fixed dose of pancreatin concentration (2000 LU/ g lipid). 


\section{RESULTS AND DISCUSSION}

\subsection{Impact of food processing on salmon composition}

Marinated and cooked salmon exhibited different nutrient composition compared to raw salmon as a result of processing (Table 4.15). Marinating was the method affecting water and protein contents the most, with a reduction of 28 and 13\%, respectively. Salt addition is known to cause muscle dehydration, along with washing away of hydrosoluble protein, resulting in a significant protein loss (Hao, Dong, Li \& Lin, 2016). In contrast, cooking imparted in salmon a higher change in lipid content, which decreased in 5\%. High temperatures reached in microwaving caused lipid melting and its subsequent exudation, along with a partial loss of $6.5 \%$ of the soluble protein fraction (Farmer, McConnell \& Kilpatrick, 2000). Water activity was also affected by processing, which particularly decreased in the marinated salmon, by the incorporation of sucrose and salt.

Table 4.15. Nutrient composition and water activity in raw, marinated and cooked salmon prior digestion.

\begin{tabular}{lcccc}
\hline \multicolumn{1}{c}{ Sample } & $\begin{array}{c}\text { Moisture } \\
(\text { g/g d.b. })\end{array}$ & $\begin{array}{c}\text { Lipid } \\
(\text { g/g d.b. })\end{array}$ & $\begin{array}{c}\text { Protein } \\
(\text { g/g d.b. })\end{array}$ & $\mathbf{a}_{\mathbf{w}}$ \\
\hline Raw & $2.26 \pm 0.08^{\mathrm{b}}$ & $0.26 \pm 0.02^{\mathrm{ab}}$ & $0.71 \pm 0.02^{\mathrm{b}}$ & $0.989 \pm 0.002^{\mathrm{c}}$ \\
Marinated* $^{*}$ & $1.65 \pm 0.11^{\mathrm{a}}$ & $0.30 \pm 0.08^{\mathrm{b}}$ & $0.61 \pm 0.01^{\mathrm{a}}$ & $0.954 \pm 0.003^{\mathrm{a}}$ \\
Cooked & $1.60 \pm 0.20^{\mathrm{a}}$ & $0.23 \pm 0.03^{\mathrm{a}}$ & $0.65 \pm 0.05^{\mathrm{ab}}$ & $0.970 \pm 0.005^{\mathrm{b}}$ \\
\hline
\end{tabular}

* Moisture, lipid and protein content in marinated samples are expressed in grams per grams of salmon in free salt and sugar dry basis. ${ }^{\mathrm{a}-\mathrm{c}}$ Letters refer to the homogenous groups obtained for different samples of salmon (raw, marinated and cooked) at a statistical significance of $95 \%$ (p-value $<0.05)$.

Complementarily to the quantification of total lipid content, the different lipid species of salmon were determined by NMR. Concretely, NMR allows to specifically quantify triglycerides, partial triglycerides (monoglycerides and diglycerides) and free fatty acids. Looking into lipids more thoroughly, the NMR analysis (Figure 4.12) depicted that the majority of lipid species in all three undigested salmon samples were triglycerides, while free fatty acids and monoglycerides represented a small percentage (less than $5 \%$ ), and 1,2 and 1,3 diglycerides were in marginal proportions $(\approx 0)$. This 
result was expected, as the majority of dietary lipids are known to be triglyceride structures, which are thereafter the main substrate for lipases during intestinal digestion, as shown in the coming sections (Hunter, 2001). However, small differences in monoglycerides and fatty acids were detected between the three preparations, raw salmon resulting with the highest amount of fatty acids. As above-commented, part of the water content was lost during cooking and marinating. Both processes led to a decrease in fatty acids, since this chemical structure is simpler and present lower molecular weight and higher solubility in the aqueous fraction than other lipidic species. On the other hand, marinated salmon showed higher monoglyceride content than the raw and cooked samples. During the post-mortem storage, some endogenous enzymes are activated and account for different biochemical changes, their activity being determined by the amount of water in the muscle. Particularly and according to Motilva \& Toldrá, (1993), acid lipase and acid esterase enzymes, which participate in muscle lipolysis, are activated when the water activity is decreased. Thus, the explanation behind this finding could rely on the loss of water occurring in marinated salmon, and also on the presence of salt and sugar, which leads to decreased water activity (Hao et al., 2016). Furthermore, lower water activity increases the hydrolytic activity of lipases as well, since these enzymes exert their action on the hydrophobic surface of lipids (Toldrá, 2003). 


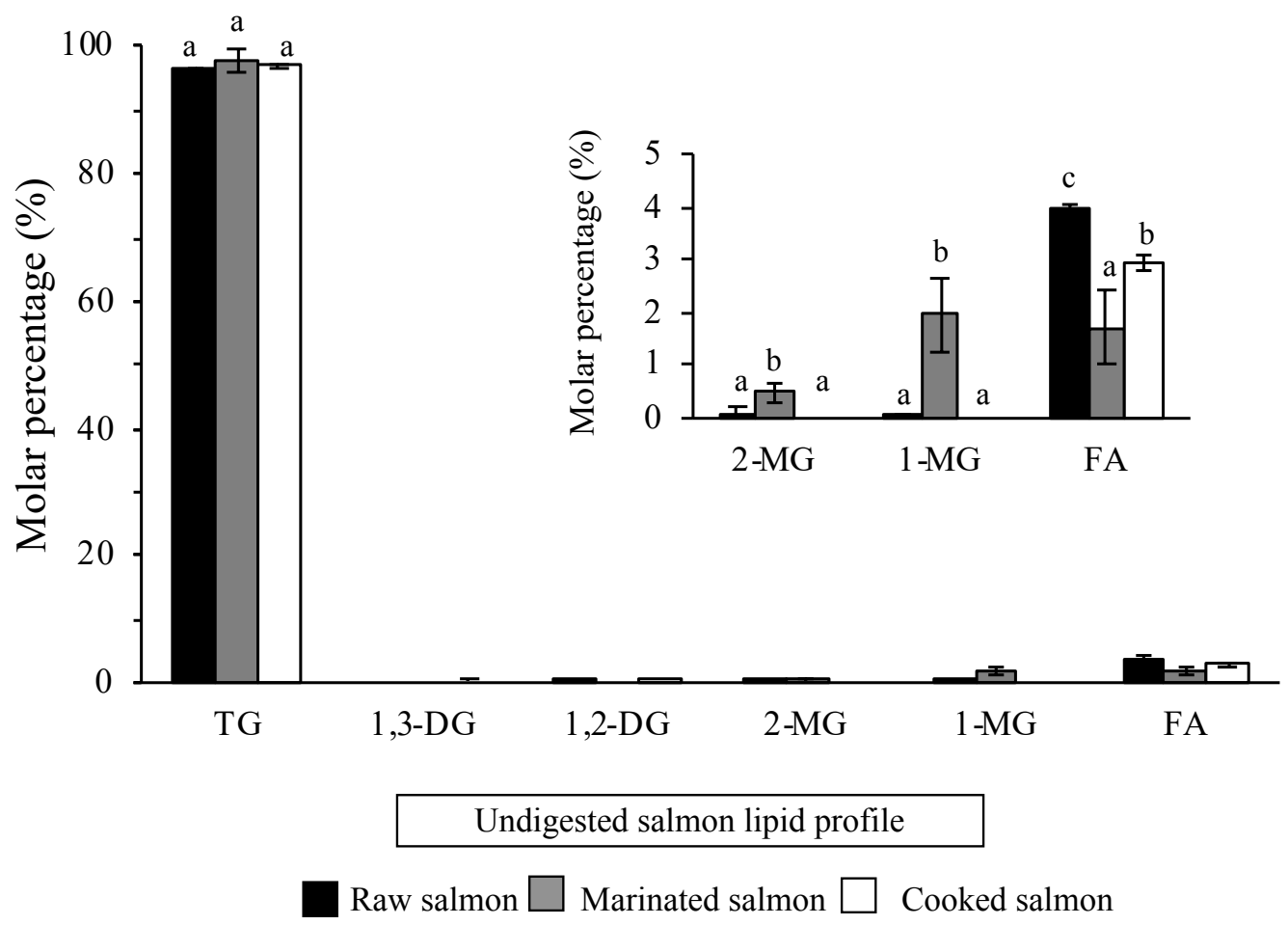

Figure 4.12. Distribution of lipid species present in raw, marinated and cooked salmon, assessed by nuclear magnetic resonance. The small graphic shows a zoom of the 2-MG, 1-MG and FA. *Different letters mean statistically significant $(\mathrm{p}<0.05)$ differences between salmon preparations.

\subsection{Influence of food processing on salmon macronutrient digestibility}

Results of matrix degradation index (MDI), lipolysis and proteolysis of raw, marinated and cooked salmon when digested in simulated standard in vitro digestion conditions (intestinal $\mathrm{pH}$ of 7 , bile salts concentration of $10 \mathrm{mM}$ and pancreatic concentration of 2000 LU/g lipid) are shown in Figure 4.13A.

During digestion, several key factors contribute to the progressive disruption of the food matrix, including the enzymes taking part throughout the gastrointestinal tract, the acidic conditions in each stage, and the peristaltic movements. Previous food processing also affects the mechanical changes experimented by the food matrix during digestion. Thus, cooked salmon presented the least MDI after gastrointestinal digestion, while marinated process did not show differences compared to raw salmon (Figure 4.13A). This result could be probably related to protein denaturation induced by the high temperatures reached during microwave-cooking (Asensio-Grau et al., 2018). Overall, 
MDI provides a relevant insight to figure out complex solid matrices' disruption during digestion. In most of the cases, the release and digestibility of nutrients are influenced by the complexity of the food matrix (Guo et al., 2017). In general, the MDI (\%) is directly proportional to macronutrient digestibility (Asensio-Grau et al., 2018; AsensioGrau et al., 2019 (a)). However, the lower degradation achieved by cooked salmon was not directly related to the nutrient digestibility thereafter, as later on discussed.

Concerning protein digestibility (Figure 4.13A), marinated and cooked salmon showed a slight (but not statistically significant) decrease in proteolysis compared to the raw counterpart. Cooking temperatures and times seem to be the main factors affecting protein structure during cooking process, due to underlying mechanisms such as aggregation and oxidation (Asensio-Grau et al, 2018; Bax et al., 2012; Promeyrat, Gatellier, Lebret, Kajak-Siemaszko, Aubry \& Sante-Lhoutellier, 2010). Similarly, marinating promotes protein oxidation, affecting functionality due to cleavage of protein bounds or modifications in aminoacids side chains (Zhang, Xiao, \& Ahn, 2013; Estévez, Ventanas, \& Cava, 2005). However, the relevance of the changes imparted by processing on proteolysis depends on luminal gastrointestinal conditions as well, as explained in the next section.

Concerning lipolysis, the structural changes imparted by the different processing techniques showed an impact, but the accounted effects in the three salmon types were different than that in proteolysis (Figure 4.13A). Focusing on total lipolysis extent at the end of the intestinal stage, $57 \%$ was registered in raw salmon. Compared to this one, cooked salmon showed improved lipolysis (68\%), while marinating led to a decrease to $45 \%$. Increased lipolysis in the cooked sample can be explained by higher lipid release during cooking (exudation), thus allowing for higher extractability during digestion (Larsen, Quek \& Eyres, 2010) and eventual lipolysis. In contrast, lipids in raw salmon seem to be more strongly bound to the matrix tissue, becoming difficult to release during digestion. Indeed, despite the literature reports that $95 \%$ of dietary lipids digestion is generally achieved, recent studies in specific foods reveal that some food characteristics, such as the matrix structure or the nature of lipids can prevent from complete hydrolysis (Guo et al., 2017; Calvo-Lerma et al., 2018). In this sense, the relatively low lipolysis 
extents obtained in this study, could be explained by the complex food matrix of salmon in which lipid fraction is entrapped in a protein fibres structure. Similarly, Grundy et al. (2016) found that in almonds, the lignin structure of the plant cell walls in which lipids are contained, prevented from being release to the digestion medium, resulting in lipolysis extents lower than $60 \%$.

Conversely, the explanation for lower lipolysis as a consequence of marinating could be supported by the presence of $\mathrm{NaCl}$ in the digestive medium. During marinating, salt and sugar were solubilised into sample muscle water by osmosis (Rastogi, 2020), and thereafter released to the digestion medium. According to Chaparro, Gil \& Aristizábal (2011), a concentration of salt above $0.4 \mathrm{M}$ increases the ionic strength in the liquid medium and reduces the interfacial activity of emulsifiers. Of note, effective lipid digestion depends on the presence of emulsifiers, such as bile salts, at the surface of fat droplets. Considering that in marinated salmon $25 \%$ of total weight was salt (1.07 M in the intestinal medium), the formation of lipid micelles could have been affected by the high ionic strength.

In addition to the quantification of total lipolysis extent, the different lipid species (triglycerides, diglycerides, monoglycerides and fatty acids) coming from the hydrolytic process on lipids were determined by NMR. The quantification of these lipolytic products allows for estimation of lipolysis extent, and the bioaccessible fraction by considering monoglycerides and free fatty acids. In Figure 4.13B, results obtained from the NMR spectra are presented for the three salmon products. They are coherent with previous literature (Hunter, 2001) because, as expected, total triglycerides decreased while free fatty acids increased during digestion. The higher amount of 1,2-DG released during digestion could be explained by the pancreatic lipase stereopreference for the sn3 position in the triglyceride (Carrière et al., 1997). Moreover, pancreatic lipase has less affinity for hydrolysing the ester bond in the sn-2 position in the triglyceride. Therefore, the low amount of 1,3-DG presented in the digested sample could be mainly due to the 1,2-DG isomerization reaction, which is catalysed by the free fatty acid released during digestion (Nieva-Echevarría et al., 2015; Spyros, Philippidis, \& Dais, 2004). On the other hand, as the figure shows, processing also had a determinant role in the resulting 
lipolysis species. Concretely, cooking led to a higher amount of 1,2-DG, 1,3- DG and FA release after digestion, while marinated process favoured the most a decrease of diglycerides and fatty acids species.

A

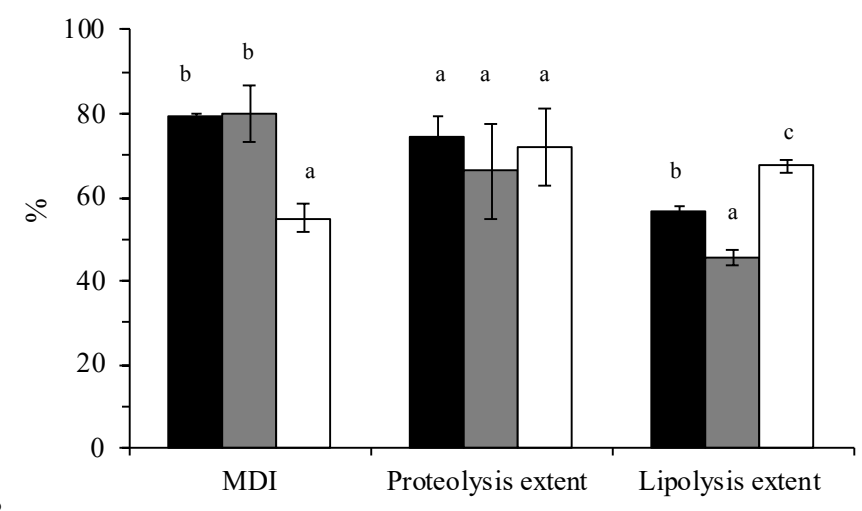

$\mathrm{B}$

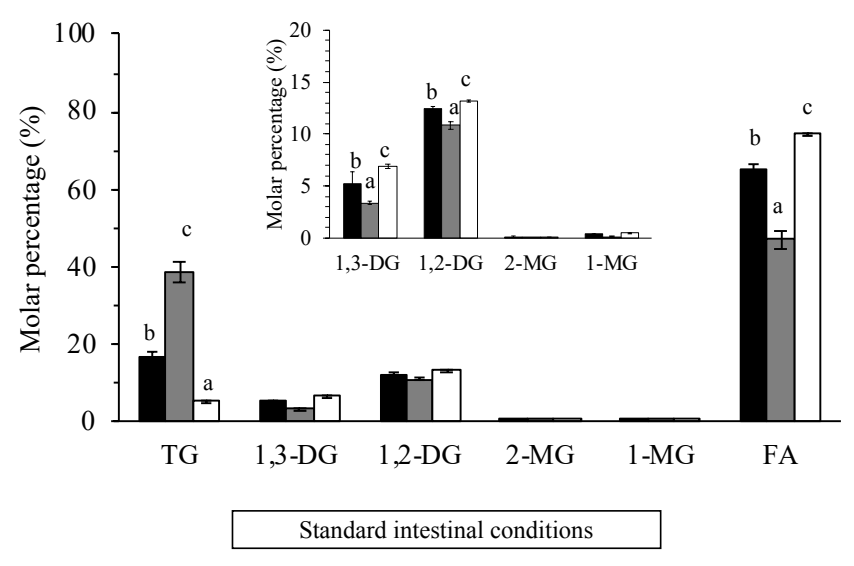

$\square$ Raw salmon $\square$ Marinated salmon $\square$ Cooked salmon

Figure 4.13. Matrix degradation index (\%), proteolysis (\%) and lipolysis extent (\%) achieved in raw, marinated and cooked salmon under standard intestinal conditions $(\mathrm{pH} 7$, bile salts concentration $10 \mathrm{mM}$ ) and pancreatin concentration $2000 \mathrm{LU} / \mathrm{g}$ lipid (A). Distribution of lipid species (molar percentage) in terms of triglycerides (TG), 1,3-diglycerides (1,3-DG), 1,2diglycerides (1,2-DG), 2-monoglycerides (2-MG), 1-monoglycerides (1-MG) and fatty acids (FA) under standard intestinal conditions and pancreatin concentration $2000 \mathrm{LU} / \mathrm{g}$ lipid (B). The small graphic shows a zoom of the 1,3-DG, 1,2-DG, 2-MG and 1-MG. *Different letters mean statistically significant $(\mathrm{p}<0.05)$ differentces between salmon preparations. Results correspond to $120 \mathrm{~min}$ of intestinal digestion. 
Therefore, comparing Figure 4.13A and 4.13B, the differences in lipolysis among the three samples depicted the same pattern as in the results obtained by means of the free fatty acid kit: cooked salmon resulted in the highest molar percentage of free fatty acids, followed by raw and marinated salmon. When assessing the correlation between both methods (NMR and free fatty acid kit), a correlation coefficient of 0.97 was obtained $(\mathrm{p}<0.001)$. Thus, in this study a comprehensive assessment of lipolysis was conducted, which was also validated against two methods.

Overall, the present results evidence that different processing techniques applied to salmon have an impact on nutrient digestibility. However, as before commented, intestinal conditions can further modulate the fate of protein and lipid digestibility. These are addressed and discussed in the coming section.

\subsection{Impact of intestinal $\mathrm{pH}$ and bile salts concentration on macronutrients digestibility in salmon products}

Digestive fluids are mainly composed by salts, enzymes and amphiphilic molecules that facilitate macronutrient breakdown and absorption. Digestive fluids secretion and composition are commonly altered in some pathologies, especially in EPI and diseases affecting the biliary tract. In order to understand digestibility mechanisms in altered intestinal conditions, the study of these variables should be addressed, besides the sole objective of assessing the food matrix effect. Previous studies have focused on characterising the role of gastrointestinal conditions on macronutrient digestibility, in the context of EPI, pointing out that amongst them, intestinal $\mathrm{pH}$ and bile salts concentration are the major determinants (Calvo-Lerma et al., 2019). However, both factors entail variable effects on digestibility depending on the type of food (AsensioGrau et al., 2019 (b); Calvo-Lerma et al., 2018). The intestinal environment is therefore a cornerstone and should be considered in lipid digestibility studies.

Consequently, in the present study, two different sets of altered intestinal conditions were simulated: reduced $\mathrm{pH}$ with normal bile salts concentration $\mathrm{pH} \mathrm{6}$, bile salts 10 $\mathrm{mM}$ ) which represent a standard EPI situation due to reduced sodium bicarbonate pancreatic secretion (Humbert et al 2018); and the worst-case scenario with reduced $\mathrm{pH}$ 
and bile concentration ( $\mathrm{pH} 6$, bile salts $1 \mathrm{mM}$ ) which is likely to occur when EPI is combined with reduced biliary secretion (Humbert et al 2018; Carrier et al., 2005). Results of MDI, proteolysis and lipolysis under the mentioned simulated altered conditions and fixed pancreatic concentration of $2000 \mathrm{LU} / \mathrm{g}$ lipid are presented in Figure

\subsection{4 (A and B).}

A

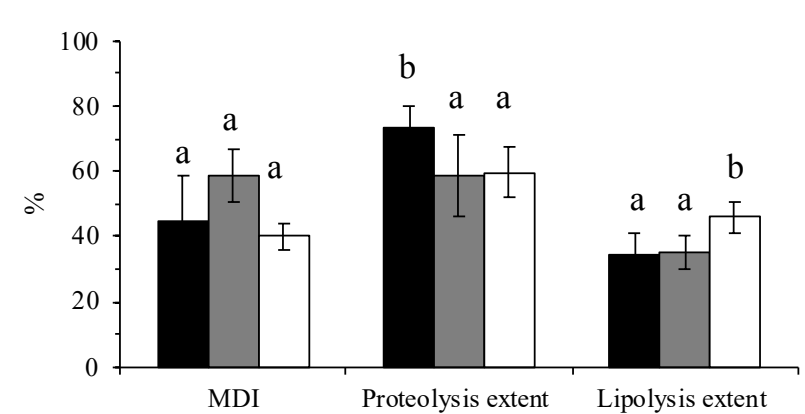

$\mathrm{C}$

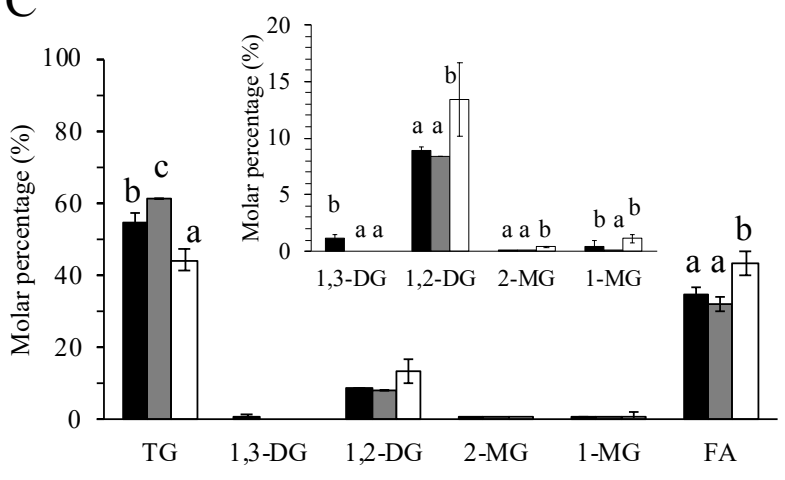

reduced $\mathrm{pH}$ and bile salts concentration
$\mathrm{B}$

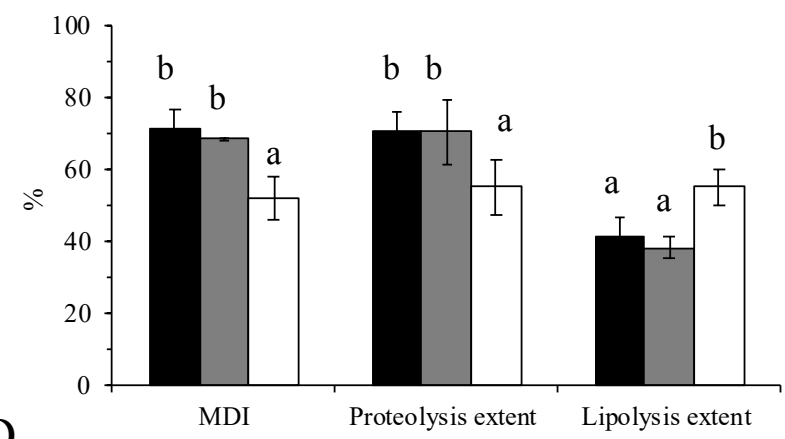

$\mathrm{D}$

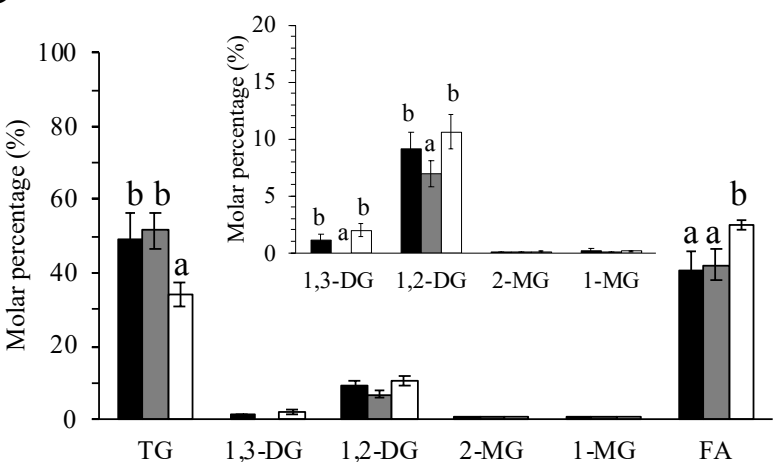

reduced $\mathrm{pH}$ and normal bile salts concentration

Raw salmon $\square$ Marinated salmon

Cooked salmon

Figure 4.14. Matrix degradation index (\%), proteolysis (\%) and lipolysis extent (\%) in the salmon samples after in vitro digestion under both altered intestinal scenarios and pancreatin concentration of $2000 \mathrm{LU} / \mathrm{g}$ lipid: reduced $\mathrm{pH}$ and bile salts concentration $(\mathrm{pH} 6$, bile salts concentration $1 \mathrm{mM})(\mathbf{A})$ and reduced $\mathrm{pH}$ and normal bile salts concentration ( $\mathrm{pH} 6$, bile salts concentration $10 \mathrm{mM}$ ) (B). Distribution of lipid species (molar percentage) under both intestinal scenarios and pancreatin concentration $2000 \mathrm{LU} / \mathrm{g}$ lipid: reduced $\mathrm{pH}$ and bile salts concentration (C) and reduced $\mathrm{pH}$ and normal bile salts concentration (D). The small graphic shows a zoom of the 1,3-DG, 1,2-DG, 2-MG and 1-MG. *Different letters mean statistically significant $(\mathrm{p}<0.05)$ differences between salmon preparations. Results correspond to $120 \mathrm{~min}$ of intestinal digestion. 
Matrix degradation was conditioned by the intestinal scenario, either by reduced $\mathrm{pH}$ or by both low $\mathrm{pH}$ with low bile salts concentration. As the main constituents of salmon are protein and lipid, the MDI mainly depends on the protein and lipid structural changes occurring during digestion. In the framework of altered intestinal conditions, these showed to compromise protein hydrolysis, which could be mainly attributed to the low concentration of bile salts. According to Gasset, Vora, Hofmann, Gray \& Khosla (2007), bile salts presence is proportionally related to the pancreatic proteases-effected (trypsin and chymotrypsin) protein digestion. Besides, surfactants as bile salts, are known to affect the protein structure making it more accessible to the proteolytic enzymes (Mackie \& Macierzanka, 2010). Low intestinal $\mathrm{pH}$ also led to decreasing proteolysis, since $\mathrm{pH}$ 8.1 is the optimal for trypsin activity, and $\mathrm{pH} 7.8$ is for chymotrypsin (Minekus et al., 2014). Thus, the main changes in MDI during digestion in altered conditions could be explained by the proteolysis extent in salmon. Apart from differences in proteolysis compared to the standard intestinal conditions, salmon processing techniques led to different patterns, as above anticipated. In normal intestinal conditions protein changes resulting from processing did not exhibit a significant effect on proteolysis. However, conformational alterations of proteins affecting molecule solubility seems to have a noticeable effect on proteolysis under suboptimal intestinal conditions. Both marinating and cooking processes seemed to lead to protein hydrophobicity, aggregation, interfering in protein hydrolysis during digestion, as previously described by Sun, Zhou, Zhao, Yang \& Cui (2011).

As expected, compared to the standard healthy conditions (Figure 4.13), total lipolysis extent significantly decreased in all fish preparations. The optimal $\mathrm{pH}$ for the pancreatin activity ranges between 7 and 9 (Li \& Somerset, 2014). On the other hand, the bile salts help in the emulsification of fat droplets, contributing to decrease particle size, thus enhancing lipase access lipolysis (Maldonado-Valderrama et al., 2011). With regard to the resulting lipidic species (NMR) (Figure 4.14 C and D), the amounts of generated monoglycerides (1-MG or 2-MG) were insignificant in all cases. The concentration of diglycerides (1,2-DG or 1,3-DG) were, however, dependent on the intestinal conditions, particularly in raw and marinated salmon. Standard $\mathrm{pH}(7)$ and bile 
salts concentration (10 mM) led to slightly higher release of 1,2-DG. Despite pancreatic lipases rarely deliver 1,3-DG, their presence in low proportions indicate the possible 1,2DG isomerization reactions during digestion (Nieva-Echevarría et al., 2015). Conversely, the presence of 1,2-DG on favourable intestinal conditions suggests the adequacy of the intestinal environment to promote lipid digestibility, specifically regarding the role of bile salts. For their part, low $\mathrm{pH}$ and also low bile salts concentration contribute to decreased 1,2-DG and FA release (Figure 4.14 C and D).

Altogether, results confirm that processing and intestinal environment conditions are determinants in the process of digestion. Taking the advantage this multivariable study offered, the relative effect that each variable on proteolysis and lipolysis was assessed by means of estimating the variance. Table 4.16 shows a multivariate ANOVA to evaluate the factor (intestinal conditions or processing) that affected (F-ratio) the response variables (MDI, proteolysis extent, lipolysis extent and molar percentage of FA) the most. The standard intestinal conditions and the both altered intestinal conditions were taken into account for the multifactor analysis of variance. As presented in Table 4.16, food processing and also intestinal conditions affected matrix degradation during digestion and had a similar and significant effect on lipid and protein digestibility. The intestinal conditions were the factors affecting lipolysis the most, both in terms of lipolysis extent and molar percentage of fatty acids, while the processing method presented a higher impact on proteolysis in both unfavourable EPI intestinal scenarios.

Table 4.16. F-ratio obtained from factorial ANOVA analysis for MDI (\%), proteolysis extent (\%), Lipolysis extent (\%) and Molar percentage of FA (\%). Factors included for the analysis were intestinal conditions and cooking method. The multifactor ANOVA was applied only to the data obtained at a fixed dose of $2000 \mathrm{LU} / \mathrm{g}$ fat.

\begin{tabular}{|c|c|c|c|c|c|c|c|c|}
\hline \multirow{2}{*}{$\begin{array}{l}\text { Principal effects } \\
\text { Intestinal conditions }\end{array}$} & \multicolumn{2}{|c|}{$\begin{array}{l}\text { MDI } \\
\text { (\%) }\end{array}$} & \multicolumn{2}{|c|}{$\begin{array}{c}\text { Proteolysis } \\
\text { extent } \\
(\%)\end{array}$} & \multicolumn{2}{|c|}{$\begin{array}{c}\text { Lipolysis } \\
\text { extent } \\
(\%)\end{array}$} & \multicolumn{2}{|c|}{$\begin{array}{c}\text { Molar percentage } \\
\text { of FA (NMR) } \\
(\%)\end{array}$} \\
\hline & 17.93 & $* *$ & 3.45 & $*$ & 58.01 & $* *$ & 77.39 & $* *$ \\
\hline Processing technique & 18.08 & $* *$ & 5.86 & $* *$ & 34.06 & ** & 24.45 & $* *$ \\
\hline
\end{tabular}

ns: non-statistical differences ( $\mathrm{p}>0.05$ ). $\mathrm{p}<0.05^{*}: \mathrm{p}<0.001^{* *}$; MDI, matrix degradation index. 


\subsection{Influence of pancreatin concentration on lipid and protein digestibility in salmon products}

As shown in the previous section, the intestinal conditions are crucial for the optimal digestibility of salmon macronutrients, particularly lipids. Shedding light on this situation is of special relevance in EPI, in which energy and lipid dietary intake requirements are increased ( $40 \%$ from total daily energy intake). In addition, the lipid supply should be represented by healthy sources, i.e. with polyunsaturated fatty acid profile (Turck et al., 2016). Hence, salmon presents as an ideal food to support the nutritional treatment of EPI, as it contains considerable amount of fat, which is mainly omega-3. As a consequence of EPI, patients have to take oral supplements of pancreatic enzymes to enable digestion. So, optimising the dose of this supplements to maximise lipolysis and eventual energy uptake, would be a worthwhile purpose.

In this sense, the present study addressed lipolysis and proteolysis extents obtained with different pancreatin concentration $(0,2000,4000$ and $6000 \mathrm{LU} / \mathrm{g}$ lipid) under both possible intestinal scenarios in EPI subjects ( $\mathrm{pH} 6$ - bile salts concentration $1 \mathrm{mM}$ and pH 6 - bile salts concentration $10 \mathrm{mM}$ ). Figure 4.15 shows MDI, proteolysis and lipolysis extents obtained in all salmon samples at the different enzyme concentrations. The effect of increasing pancreatin concentration on MDI was noticed in the worst-case set of conditions, while it showed no effect in the case of normal bile salt concentration $(10 \mathrm{mM})$. Regarding proteolysis, the pancreatin concentration seemed to have only minor effects, except in the case of cooked salmon, in which protein were denatured as a consequence of the high temperatures. The subsequent conformational changes imparted by this processing seem to have negatively affected the role of proteases contained in the enzymatic supplement in breaking down the protein molecules. Moreover, denatured proteins suggest to have influenced the interaction between fish protein and bile salts, as discussed in the previous section.

Concerning lipid hydrolysis (the main nutrient of interest in this framework) cooked salmon exhibited the highest extent, compared to raw and marinated samples, regardless the pancreatic concentration; while similar results were achieved in marinated and raw salmon, in both sets of simulated conditions. Focusing on cooked salmon, lipid 
digestibility showed an increasing tendency with the pancreatin concentration in the frame of worst-case conditions ( $\mathrm{pH} 6$ - bile salts concentration $1 \mathrm{mM}$ ), while no improvement was shown when the conditions included normal bile salts concentration (pH 6 - bile salts concentration $10 \mathrm{mM}$ ). In contrast, raw salmon resulted in slight increases of lipolysis as the pancreatic concentration increased in both situations. Finally, marinated salmon, in the two scenarios, allowed for increased lipolysis when moving from 2000 to $4000 \mathrm{LU} / \mathrm{g}$ lipid, but remaining stable if the pancreatin concentration increased to $6000 \mathrm{LU} / \mathrm{g}$ lipid. None of the experiments led to lipolysis extents values above $60 \%$. So, despite the registered increasing tendency with the pancreatin concentration in some cases could suggest further increments in total lipolysis, this result would prevent from expecting complete fat hydrolysis.

Considering the maximum pancreatin concentration, either with normal or reduced bile salts concentration, salmon fat would not be optimally digested. At most, around 60 $\%$ of lipolysis extent could be expected in the case of cooked salmon at the maximum pancreatin concentration. In practical terms, and considering the increase from 4000 to $6000 \mathrm{LU} / \mathrm{g}$ fat only accounts for minor increase of lipolysis, $4000 \mathrm{LU} / \mathrm{g}$ lipid would be the optimal pancreatin concentration for salmon intake in the context of EPI intestinal conditions. So, a recommendation for pancreatic enzyme replacement therapy in EPI should be supplying $4000 \mathrm{LU} / \mathrm{g}$ of lipid when salmon is consumed. 


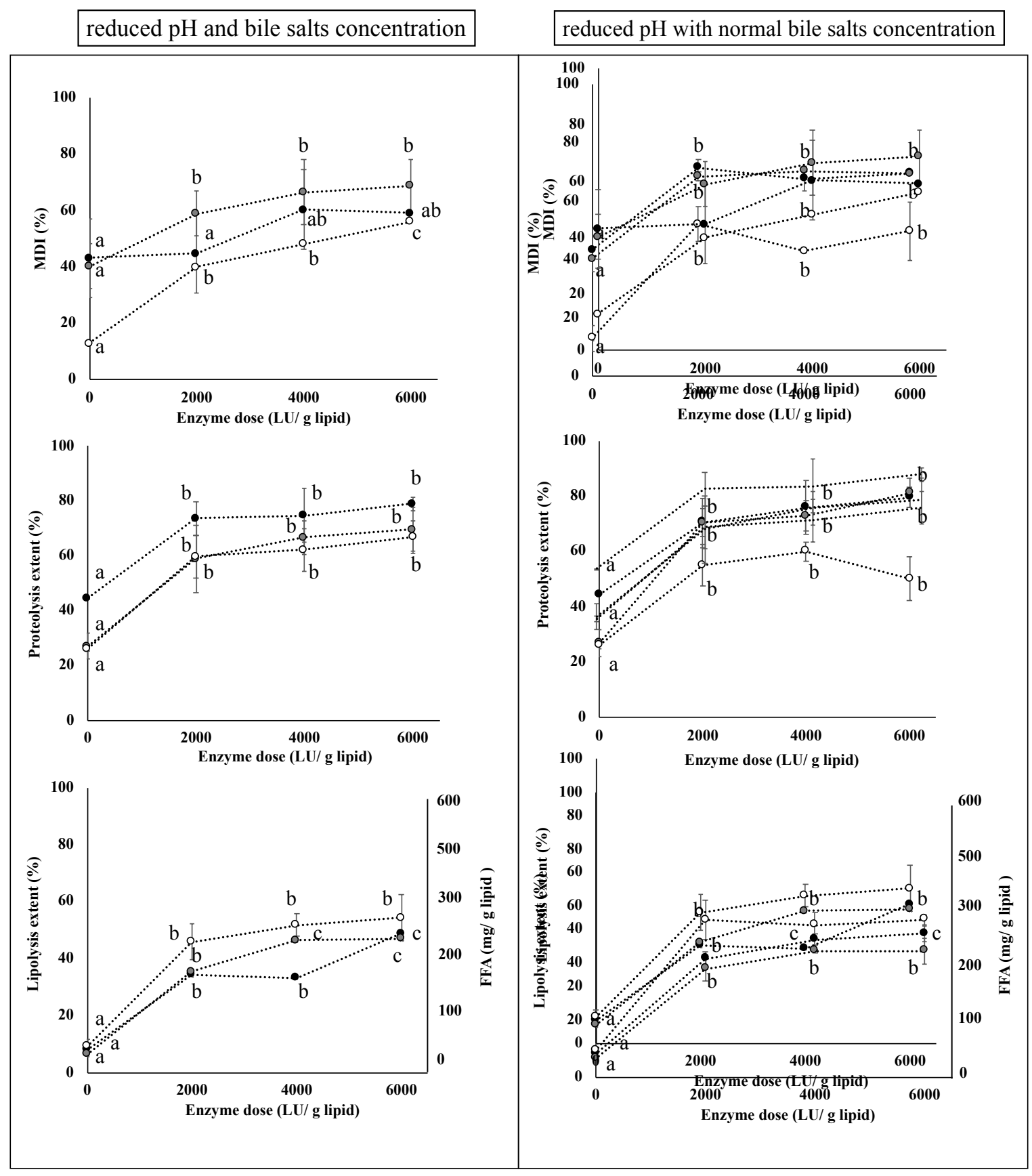

Raw salmon Marinated salmon $\bigcirc$ cooked salmon

Figure 4.15. Matrix degradation index (\%), proteolysis (\%) and lipolysis extent (\%) achieved in raw, marinated and cooked salmon at different pancreatin concentration $(0,2000,4000$ and 6000 $\mathrm{LU} / \mathrm{g}$ lipid. The corresponding protease activities were $0,44,88$ and $132 \mathrm{PU} / \mathrm{g}$ protein in raw salmon, 0, 70, 140 and $210 \mathrm{PU} / \mathrm{g}$ protein in marinated salmon and 0, 43, 87 and $130 \mathrm{PU} / \mathrm{g}$ protein in cooked salmon. *Different letters mean statistically significant $(\mathrm{p}<0.05)$ differences between the pancreatin concentration. Results correspond to 120 min of intestinal digestion. 
Despite satisfactory levels of salmon fat digestion should not be expected in patients coursing with EPI, the simulation of the healthy conditions, according to the present study, would not either fulfil complete lipolysis, and around $80 \%$ would be the expected extent. Incomplete lipid digestion may have several implications. Recent studies suggest that undigested fat reach the colon carrying away bile salts (Louis et al., 2014). The microbiota in the colon is able to metabolise the bile salts in secondary bile acids, which can accumulate to high levels in the enterohepatic circulation of some individuals and may contribute to the pathogenesis of colon cancer, gallstones, and other gastrointestinal (GI) diseases (Ridlon et al., 2006). More generally, incomplete lipid digestion is directly associated with lipid malabsorption and excretion in faeces, which is a regular condition in cystic fibrosis and pancreatic insufficiency. Thus, the energy value of a food with incomplete lipid digestion should be considered to be lowered, rather than assuming the value of a complete nutrient digestion. The elimination of fat with faeces also implies that liposoluble vitamins are carried away too (Domínguez-Muñoz, 2011).

\section{CONCLUSIONS}

The results of the present study provide a thorough characterisation of digestibility of salmon macronutrients (lipids and protein) as conditioned by processing and intestinal conditions. In the situation of standard healthy intestinal conditions, proteolysis was not largely affected by processing. Lipid digestibility, however, improved when salmon was cooked, marinated process resulting in the lowest lipolysis extent. Nonetheless, the intestinal conditions negatively affected both salmon proteolysis and lipolysis, specifically the combination of low $\mathrm{pH}(6)$ and low bile salts concentration $(1 \mathrm{mM})$ corresponding to the most adverse intestinal scenario of EPI. The reduced $\mathrm{pH}$ and bile salts concentration also promoted decreased 1,2-DG and FA release, thus representing a drawback for lipolysis.

The results also confirmed that the concentration of pancreatin did not have an effect on proteolysis, being $2000 \mathrm{LU} / \mathrm{g}$ lipid the optimal dose to reach the highest proteolysis under both EPI intestinal conditions. Only marinated salmon increased lipolysis when moving from 2000 to $4000 \mathrm{LU} / \mathrm{g}$ fat, but not changing if the dose increased to $6000 \mathrm{LU} / \mathrm{g}$ 
fat. Despite of increasing pancreatin concentration under both EPI intestinal scenarios, lipolysis extent did not reach values above of $60 \%$ regardless the processing technique.

Overall, salmon preparations affect macronutrients digestibility, lipolysis being compromised in any intestinal scenario. The consumption of cooked salmon instead of other preparations would be recommendable in order to enhance lipolysis, especially in EPI patients. The results of this study can provide evidence to establish dietary recommendations regarding salmon consumption and support to explain results in further in vivo studies.

\section{ACKNOWLEDGEMENTS}

The authors would like to thank the Conselleria de Educació i Investigació de la Generalitat Valenciana and also the European Union ("El Fondo Social Europeo (FSE) invierte en tu futuro") for the $\mathrm{PhD}$ scholarship given to Andrea Asensio Grau (ACIF/2017/008). This study was developed thanks to the equipment funded with the support from the Generalitat Valenciana IDIFEDER/2018/041 (PO FEDER Comunitat Valenciana 2014-2020)

\section{REFERENCES}

AOAC (2000). Official methods of analysis of AOAC International. (17th ed.). Gaithersberg, Maryland: Association of Official Chemists.

Asensio-Grau, A., Peinado, I., Heredia, A. \& Andrés, A. (2018). Effect of cooking methods and intestinal conditions on lipolysis, proteolysis and xanthophylls bioaccessibility of eggs. Journal of functional foods, 46, 579-586.

Asensio-Grau, A., Calvo-Lerma, J., Heredia, A., \& Andrés, A. (2019) (a). Fat digestibility in meat products: influence of food structure and gastrointestinal conditions. International Journal of Food Sciences and Nutrition, 70(5), 530-539.

Asensio-Grau, A., Peinado, I., Heredia, A., \& Andrés, A. (2019) (b). In vitro study of cheese digestion: Effect of type of cheese and intestinal conditions on macronutrients digestibility. LWT, 113, 108278. 
Bax, M. L., Aubry, L., Ferreira, C., Daudin, J. D., Gatellier, P., Rémond, D., \& Santé-Lhoutellier, V. (2012). Cooking temperature is a key determinant of in vitro meat protein digestion rate: Investigation of underlying mechanisms. Journal of Agricultural and Food Chemistry, 60, 2569-2576.

Brodkorb, A., Egger, L., Alminger, M., Alvito, P., Assunção, R., Ballance, S., ... \& Clemente, A. (2019). INFOGEST static in vitro simulation of gastrointestinal food digestion. Nature protocols, 14(4), 991-1014.

Calder, P.C. (2006). n-3 Polyunsaturated fatty acid, inflammation, and inflammatory disease. American Journal of Clinical Nutrition, 83, 1505S-19S.

Calvo-Lerma, J., Martínez-Barona, S., Masip, E., Fornés, V., \& Ribes-Koninckx, C. (2017). Pancreatic enzyme replacement therapy in cystic fibrosis: dose, variability and coefficient of fat absorption. Revista Española de Enfermedades Digestivas, 109 (10), 684-689.

Calvo-Lerma, J., Fornés-Ferrer, V., Heredia, A., Andrés, A. (2018). In Vitro Digestion of Lipids in Real Foods: Influence of Lipid Organization Within the Food Matrix and Interactions with Nonlipid Components. Journal of Food Science, 83(10), 2629-2637.

Calvo-Lerma, J., Fornés-Ferrer, V., Heredia, A., Andrés, A. (2019). In vitro digestion models to assess lipolysis: The impact of the simulated conditions for gastrointestinal $\mathrm{pH}$, bile salts and digestion fluids. Food Research International, 125, 108511.

Chaparro, S. P., Gil, J. H., \& Aristizábal, I. D. (2011). Effect of hydration and baking on the physical and functional properties of vitabosa flour (deeringiana). Vitae, 18(2), $133-143$.

Carrière, F., Rogalska, E., Cudrey, C., Ferrato, F., Laugier, R., \& Verger, R. (1997). In vivo and in vitro studies on the stereoselective hydrolysis of tri-and diglycerides by gastric and pancreatic lipases. Bioorganic \& medicinal chemistry, 5, 429-435.

Carrière, F., P. Grandval, C. Renou, A. Palomba, F. Prieri, J. Giallo, F. Henniges, S. Sander-Struckmeier, \& R. Laugier. 2005. Quantitative study of digestive enzyme 
secretion and gastrointestinal lipolysis in chronic pancreatitis. Clinical Gastroenterology and Hepatology, 3, 28-38.

Cohen, J., Bellinger, D., Connor, W., Krisetherton, P., Lawrence, R., Savitz, D., Shaywitz, B., Teutsch, S., \& Gray, G. (2005). A quantitative risk-benefit analysis of changes in population fish consumption. American Journal of Preventive Medicine, 29(4), 325-334.

Domínguez-Muñoz, J. E. (2011). Chronic pancreatitis and persistent steatorrhea: what is the correct dose of enzymes? Clinical Gastroenterology and Hepatology, 9, 541546.

Estévez, M., Ventanas, S., \& Cava, R. (2005). Protein oxidation in frankfurters with increasing levels of added rosemary essential oil: Effect on color and texture deterioration. Journal of Food Science, 70 (7), c427-c432.

Farmer, L. J., McConnell, J. M., \& Kilpatrick, D. J. (2000). Sensory characteristics of farmed and wild Atlantic salmon. Aquaculture, 187(1-2), 105-125.

Gasset, J., Vora, H., Hofmann, A. F., Gray G. M., \& Khosla C. (2007). Enhancement of dietary protein digestion by conjugated bile acids. Gastroenterology, 133, 16-23.

Gelfond, D., Ma, C., Semler, J., \& Borowitz, D. (2013). Intestinal pH and gastrointestinal transit profiles in cystic fibrosis patients measured by wireless motility capsule. Digestive Diseases and Sciences, 58(8), 2275-2281.

Gladyshev, M. I., Sushchik, N. N., Gubanenko, G. A., Demirchieva, S. M., \& Kalachova, G. S. (2006). Effect of way of cooking on content of essential polyunsaturated fatty acids in muscle tissue of humpback salmon (Oncorhynchusgorbuscha). Food Chemistry, 96(3), 446-451.

Grundy, M. M., Carrière, F., Mackie, A. R., Gray, D. A., Butterworth, P. J., \& Ellis, P. R. (2016). The role of plant cell wall encapsulation and porosity in regulating lipolysis during the digestion of almond seeds. Food \& Function, 7(1), 69-78.

Guo, Q., Ye, A., Bellissimo, N., Singh, H., \& Rousseau, D. (2017). Modulating fat digestion through food structure design. Progress in Lipid Research, 68, 109-118. 
Hao, Z., Dong, H., Li, Z., \& Lin, H. (2016). Analysis of physicochemical properties during the processing of Yiluxian, a traditional chinese low-salt fish product. International Journal of Food Science \& Technology, 51(10), 2185-2192.

Hosomi, R., Yoshida, M., \& Fukunaga, K. (2012). Seafood consumption and components for health. Global Journal of Health Science, 4(3), 72.

Humbert, L., Rainteau, D., Tuvignon, N., Wolf, C., Seksik, P., Laugier, R., \& Carrière, F. (2018). Postprandial bile acid levels in intestine and plasma reveal altered biliary circulation in chronic pancreatitis patients. Journal of Lipid Research, 59(11), 2202-2213.

Hunter, J. E. (2001). Studies on Effects of Dietary Fatty Acids as Related to Their Position on Triglycerides. Lipids, 36(7), 655-668

Larrazábal-Fuentes, M.J., Escriche-Roberto, I., \& Camacho-Vidal, M.D.M. (2009). Use of immersion and vacuum impregnation in marinated salmon (Salmosalar) production. Journal of Food Processing and Preservation, 33(5):635-650.

Larsen, D., Quek, S. Y., \& Eyres, L. (2010). Effect of cooking method on the fatty acid profile of New Zealand King Salmon (Oncorhynchus tshawytscha). Food Chemistry, 119(2), 785-790.

Lamothe, S., Azimy, N., \& Bazinet, L. (2014). Function Interaction of green tea polyphenols with dairy matrices in a simulated gastrointestinal environment. Food \& Function, 5, 2621-2631

Laub-Ekgreen, M. H., Martinez-Lopez, B., Frosch, S., \& Jessen, F. (2018). The influence of processing conditions on the weight change of single herring (Clupeaherengus) fillets during marinating. Food Research International, 108, 331-338.

Li, L., \& Somerset, S. (2014). Digestive system dysfunction in cystic fibrosis: challenges for nutrition therapy. Digestive and liver disease, 46(10), 865-874.

Louis, P., Hold, G. L. \& Flint, H. J. (2014). The gut microbiota, bacterial metabolites, and colorectal cancer. Nature reviews microbiology, 12(10), 661-672.

Mackie, A., \& Macierzanka, A. (2010). Colloidal aspects of protein digestion. Current Opinion in Colloid \& Interface Science, 15, 102-108. 
Maldonado-Valderrama, J., Wilde, P., Macierzanka, A., \& Mackie, A. (2011). The role of bile salts in digestion. Advances in colloid and interface science, 165(1), 36-46.

Minekus, M., Alminger, M., Alvito, P., Ballance, S., Bohn, T. O. R. S. T. E. N., Bourlieu, C., \& Dufour, C. (2014). A standardised static in vitro digestion method suitable for food-an international consensus. Food \& function, 5(6), 1113-1124.

Motilva, M. J., \& Toldrá, F. (1993). Effect of curing agents and water activity on pork muscle and adipose subcutaneous tissue lipolytic activity. Zeitschrift für Lebensmittel-Untersuchung und Forschung, 196(3), 228-232.

Nieva-Echevarría, B., Goicoechea, E., Manzanos, M. J., \& Guillén, M. D. (2015). Usefulness of 1H NMR in assessing the extent of lipid digestion. Food Chemistry, 179, 182-190.

Nieva-Echevarría, B., Goicoechea, E., Manzanos, M. J., \& Guillén, M. D. (2014). A method based on 1H NMR spectral data useful to evaluate the hydrolysis level in complex lipid mixtures. Food Research International, 66, 379-387.

Promeyrat, A., Gatellier, P., Lebret, B., Kajak-Siemaszko, K., Aubry, L., \& SanteLhoutellier, V. (2010). Evaluation of protein aggregation in cooked meat. Food Chemistry, 121, 412-417.

Sarkar, A., Ye, A., \& Singh, H. (2016). On the role of bile salts in the digestion of emulsified lipids. Food Hydrocolloids, 60, 77-84.

Simopoulos, A. P. (2016). An increase in the omega-6/omega-3 fatty acid ratio increases the risk for obesity. Nutrients, 8,128

Spyros, A., Philippidis, A., \& Dais, P. (2004). Kinetics of diglyceride formation and isomerization in virgin olive oils by employing 31P NMR spectroscopy. Formulation of a quantitative measure to assess olive oil storage history. Journal of Agricultural and Food Chemistry, 52, 157-164

Sun, W. Z., Zhou, F. B., Zhao, M. M., Yang, B., \& Cui, C. (2011). Physicochemical changes of myofibrillar proteins during processing of Cantonese sausage in relation to their aggregation behavior and in vitro digestibility. Food Chemistry, 129, 472-478. 
Rastogi, N. K. (2020). Applications of forward osmosis process in food processing and future implications. In Current Trends and Future Developments on (Bio-) Membranes (pp. 113-138). Elsevier.

Ridlon, J. M., Kang, D. J., \& Hylemon, P. B. (2006). Bile salt biotransformations by human intestinal bacteria. Journal of Lipid Research, 47(2), 241-259.

Toldrá, F. (2003). Muscle foods: water, structure and functionality. Food Science and Technology International, 9(3), 173-177.

Turck, D., Braegger, C. P., Colombo, C., Declercq, D., Morton, A., Pancheva, R., ... \& Schneider, S. M. (2016). ESPEN-ESPGHAN-ECFS guidelines on nutrition care for infants, children, and adults with cystic fibrosis. Clinical Nutrition, 35(3), 557-577. Zhang, W., Xiao, S., \&Ahn, D. U. (2013). Protein oxidation: basic principles and implications for meat quality. Critical Reviews in Food Science and Nutrition, 53(11), 1191-1201. 


\section{CONCLUDING REMARKS}




\section{CONCLUDING REMARKS}

Not only composition but also matrix structure plays a crucial role in food digestion and nutrients bioaccessibility. There are two main groups of structures in foods, native and processed structures, so that foods with similar composition could present different matrix structure. In the present doctoral thesis, the impact of different processes on food structure have been evaluated, in egg and salmon and in meat and cheese processing. Considering that the structural changes imparted to the food matrix can be produced by different mechanisms, concluding remarks related to objectives 1, 3 and 4 are presented accordingly:

- Physico-chemical process: the impact of two types of physical processing of food on digestion were addressed in this thesis: matrix disruption and dehydration. The effect of beating in egg and homogenisation in some meat products resulted in the food matrix breakdown or destabilisation. On the other hand, dehydration was another phenomenon observed in salmon as a consequence of marinating, which lead to the loss of water and protein denaturalisation. All these processes implying structural changes showed to affect lipid and protein digestion. In the case of egg, treatments involving structure breakdown and high temperature during cooking in omelette, impacted by decreasing lipolysis and proteolysis. On the other hand, meat products with a disrupted structure as a consequence of processing, such as sausage or hamburger, showed facilitated lipid digestibility compared to the products preserving the native structure. As for marinated salmon, the process induced reduced lipolysis compared to the cooking preparation while it increased against the raw counterpart.

- Thermal process: the application of heat to foods prior consumption provokes dehydration, protein denaturation and lipid solidification. These changes affect food structure and have showed to have an influence on lipid and protein digestibility. In eggs, lipid and protein digestion from boiled-hard egg (solid lipids) and omelette (solid lipids interacting with protein) decreased compared 
to poached egg (liquid lipids, separated from the protein fraction). In the same way, xanthophylls were also affected by cooking, being poaching and boiling the cooking methods allowing for the highest bioaccessibility. In the study of salmon, protein digestibility was not affected by cooking, however, cooking favoured lipolysis compared to the raw counterpart.

- Biochemical process: during the process of ripening in cheese, different hydrolysis reactions take place in milk by the action of the rennet. Proteolysis disaggregates the casein proteins and lipolysis is the main factor affecting the flavour. These phenomena, accounting for partial hydrolysis of protein and lipid, impact on lipid and protein bioaccessibility during the subsequent digestion process. In fact, cheeses presenting the same composition but different ripening time resulted in different lipid and protein digestion. Concretely, higher ripening times resulted in higher lipolysis and proteolysis after digestion.

The different consequences in digestion derived from composition and structural changes in food are even more compromised when gastrointestinal alterations occur. CF along with pancreatic insufficiency is a concrete example in which some alterations are produced in the small intestine (lower intestinal $\mathrm{pH}$, lower bile salts concentration and lack of pancreatic enzymes secretion). Indeed, a general observation from the results is that reduced intestinal $\mathrm{pH}$ significantly leads to decreased lipolysis extent and that the effect of the bile salts concentration is variable depending on the food matrix characteristics (objective 2). Although food digestion depends of many factors such as composition, structure and intestinal alterations, the different studies addressed in this doctoral thesis have led to analyse the global impact of all these factors on digestibility, specifically under objectives 2 and 4, and have allowed to identify which is the most relevant one in every animal-origin food group (egg, salmon, meat products and cheese).

- In egg products intestinal conditions, were the factors affecting lipolysis the most, and concretely the bile salts concentration was the most determining variable. The cooking preparation also played a significant role when simulating the altered intestinal conditions. 
- In meat products, both intestinal conditions and bile salts concentration had a significant effect on lipolysis, but in this food group, the state of the food matrix (native or disintegrated) was more determinant on lipolysis extent, as related to the matrix degradation index each type of matrix accounted for.

- In mild-cheese and fresh goat cheese lipolysis was mainly influenced by the bile salts concentration. Neither altered intestinal $\mathrm{pH}$ or bile salts concentration impacted on lipolysis in fresh goat cheese, which was able to reach equivalent lipolysis extents as in the standard intestinal conditions. However, lipolysis in aged cheese was affected by the altered intestinal conditions of $\mathrm{CF}$ (low intestinal $\mathrm{pH}$ and low bile salts concentration).

- In the same way, the variable affected the most on lipolysis in salmon was $\mathrm{CF}$ and Exocrine Pancreatin Insufficiency intestinal conditions. While proteolysis was mainly conditioned by the processing techniques.

As for the ultimate goal, the results of this thesis have contributed to establishing the optimal concentration of pancreatin supplements, used in the treatment of $\mathrm{CF}$ and pancreatic insufficiency, depending on the type of food. The optimal concentrations in each case relied not only on the food lipid content or the pancreatin concentration in the digested medium, but also the food matrix characteristics and intestinal conditions exert their role. Altogether, the results of this thesis pose the following recommendations to achieve maximum lipolysis:

- Among the three assessed egg preparations, poached egg should be preferred as it was the only variety achieving $100 \%$ of lipolysis extent at the dose of $3000 \mathrm{LU} / \mathrm{g}$ fat.

- Unstructured meat products are able to reach higher lipolysis than those meat products preserving the native fibrillar matrix structure, and these should be consumed at the dose of 2000-3000 LU/g fat, although the lipolysis to be expected are in the range of $250-600 \mathrm{mg}$ FFA/ $\mathrm{g}$ fat.

- As for cheese types, fresh goat cheese is able to reach $100 \%$ of lipolysis extent at the dose of $2000 \mathrm{LU} / \mathrm{g}$ fat, and aged cheese could achieve $80 \%$ 
with a pancreatin concentration of $4000 \mathrm{LU} / \mathrm{g}$ fat, the fresh cow cheese and the mild-aged cheese achieving at the most 65 and $40 \%$ lipolysis extents respectively.

- Cooked salmon was the assessed salmon preparation achieving maximum lipolysis at the dose of $4000 \mathrm{LU} / \mathrm{g}$ fat, although this lipolysis extent was not higher than $60 \%$.

- The most recommendable animal-origin foods for patients with $\mathrm{CF}$ and pancreatic insufficiency aiming at maximising lipolysis extent of $100 \%$, should be poached egg and fresh goat cheese. 


\section{FUTURE PERSPECTIVES}




\section{FUTURE PERSPECTIVES}

As for the immediate future, the results from this thesis have already contributed to develop an evidence-based method to adjust the amount of pancreatic enzyme supplements used in the pancreatic enzyme replacement therapy, which is integrated into a mobile application for patients with CF. The application works with a predictive algorithm that informs about the optimal dose of enzymes, based on the recommended dose that allows for the highest lipolysis extent in each food type. The results obtained in this thesis contributed to a database including the optimal dose of enzymes for each type of food. The database was the main component used by the predictive algorithm to supply a recommended dose of enzymes for a meal, taking into account the amount and the type of foods conforming it. This system was evaluated in a clinical trial with patients with $\mathrm{CF}$ and pancreatic insufficiency. The recently published study outcomes have proved the efficacy in improving the coefficient of fat absorption and gastrointestinalrelated quality of life. So, in vitro digestion studies in real food matrices have proved to be a useful and valid approach to support and enhance a medical treatment, as in the case of $\mathrm{CF}$ in particular. However, there is still room for improvement. The future of the results of this thesis in this field seem to be guaranteed.

First, we point out that future research in this field would benefit from addressing the context of $\mathrm{CF}$ and celiac disease, which is a concomitant pathology with increasing prevalence. In this sense, the number of patients adhering to the evidence-based pancreatic enzyme replacement therapy could be enlarged. So, next steps would include the study of developed gluten-free products to deliver recommendations of the optimal dose of enzymes that should be taken for those specific products. Similarly, the specific products consumed during the first stages of life (e.g., breast milk, formulas, porridges) should be studied as well to incorporate newborns and infants with $\mathrm{CF}$ as possible beneficiaries of the method to adjust pancreatic enzyme replacement therapy.

Second, the static in vitro digestion model used in this project should keep on improving by incorporating new evidences that can strength the representation of the physiological conditions of the digestion process. This is, besides considering intestinal 
$\mathrm{pH}$ or bile salts concentration, upgrades in the in vitro digestion model would benefit from: the inclusion of the simulation of duration of each stage, the volumetric secretions of intestinal fluids and their composition in electrolytes and enzymes depending on the type of food or simulating the progressive gastric emptying according to the food characteristics. Overall a more realistic and close simulation of the physiological conditions, should be targeted, possibly as a dynamic in vitro digestion model. The reproduction of the experiments in this thesis should then be evaluated against the dynamic model, from which more accurate optimal doses of enzymes could be obtained. In addition, the results obtained by means of an improved in vitro digestion model should be tested in the in vivo context.

The accuracy of the predictive algorithm of the optimal dose of enzymes before cited, is another future research field that should be targeted. At this point the study of the effect of interactions among nutrients from different food matrices being co-digested in a meal are identified as a possible means of improvement. The current algorithm provides a recommended dose of enzymes by summing up the individual optimal doses of enzymes of the foods conforming a meal. However, protein-lipid and carbohydratelipid interactions have recently showed to interfere in lipolysis, which could be translated in different optimal doses of enzymes.

Finally, the emerging simulation of the colonic stage can be incorporated to the previously described model allowing for addressing new objectives related to digestion such as the fate of non-digestible carbohydrates or non-absorbed lipids and proteins, the impact of food composition on products metabolised by the microbiota and also the progressive effect of type of diet or food intake on colonic microbiota populations. Moreover, the incorporation of the microbiota at the different stages of the digestion process would enhance the physiological reproducibility of the experiments, as it could have an impact on nutrient bioaccessibility and bioavailability. 